\title{
AVALIAÇÃO DO USO DO FLUXO DE SEIVA E DA VARIAÇÃO DO DIÂMETRO DO CAULE E DE RAMOS NA DETERMINAÇÃO DAS CONDIÇÕES HÍDRICAS DE CITROS, COMO BASE PARA O MANEJO DE IRRIGAÇÃO
}

\author{
JUAN SINFORIANo DELgado RoJAS
}

\begin{abstract}
Tese apresentada à Escola Superior de Agricultura "Luiz de Queiroz", Universidade de São Paulo, para obtenção do título de Doutor em Agronomia, Área de Concentração: Irrigação e Drenagem.
\end{abstract}

P I R A C I C A B A

Estado de São Paulo - Brasil

Fevereiro - 2003 


\title{
AVALIAÇÃO DO USO DO FLUXO DE SEIVA E DA VARIAÇÃO DO DIÂMETRO DO CAULE E DE RAMOS NA DETERMINAÇÃO DAS CONDIÇÕES HÍDRICAS DE CITROS, COMO BASE PARA O MANEJO DE IRRIGAÇÃO
}

\author{
JUAN SINFORIANO DELGADO ROJAS \\ Engenheiro Agrônomo
}

Orientador: Prof. Dr. LUIZ ROBERTO ANGELOCCI

\begin{abstract}
Tese apresentada à Escola Superior de Agricultura "Luiz de Queiroz", Universidade de São Paulo, para obtenção do título de Doutor em Agronomia, Área de Concentração: Irrigação e Drenagem.
\end{abstract}

P I R A C I C A B A

Estado de São Paulo - Brasil

Fevereiro - 2003 


\title{
Dados Internacionais de Catalogação na Publicação (CIP)
} DIVISÃO DE BIBLIOTECA E DOCUMENTAÇÃO - ESALQ/USP

\author{
Delgado Rojas, Juan Sinforiano \\ Avaliação do uso do fluxo de seiva e da variação do diâmetro do \\ caule e de ramosna determinação dascondições hídricas de citros, \\ como base para o manejo de iriga -ção / J uan Sinforia no Delgado Rojas. \\ - - Pira cic aba, 2003. \\ 110 p. : il. \\ Tese (doutorado) - Escola Superior de Agricultura Luiz de Queiroz, 2003. \\ Bibliografia.

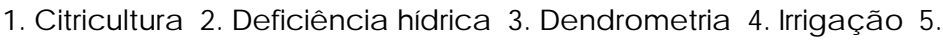 \\ Pomar 6. Transpiração vegetal I. Título
}

CDD 634.3

"Permitida a cópia total ou parcial deste documento, desde que citada a fonte - $\mathrm{O}$ autor" 
Aos meus queridos pais, Don Sinforiano e Dona Francisca que me ensinaram através da suas vivências, os melhores exemplos para vencer as incertezas da vida e confiar no futuro.

\section{Dedico}

A minha querida esposa Valéria, por estar sempre ao meu lado dedicando-me seu tempo com muito carinho e compreensão 


\section{AGRADECIMENTOS}

À Deus, por ter-me dado boa saúde e liberdade para cumprir com minhas obrigações.

À Fundação de Amparo à Pesquisa do Estado de São Paulo (FAPESP) por ter-me concedido bolsa de estudo e apoio financeiro para a realização deste curso.

À Escola Superior de Agricultura "Luiz de Queiroz" minha eterna gratidão

Ao Professor Luiz Roberto Angelocci, pelos ensinamentos, amizade e constante orientação durante meu trabalho.

À Professora Maria Isabel Ferreira, do Instituto Superior de Agricultura de Portugal, pela inestimável atenção, ensinamentos e amizade.

Aos demais Professores dos Departamentos de Engenharia Rural e de Ciências Exatas, por terem colaborado com minha formação.

Aos meus caros amigos Maurício, Walter, e Raf que colaboraram comigo deixando suas marcas neste trabalho.

Aos funcionários do Departamento de Engenharia Rural, Vanda, Sandra, Davilmar, César, Hélio, Gilmar, Lino e António por estarem sempre prestativos.

Aos funcionários do Departamento de Ciências Exatas, Robinson, Ana, Edivaldo e Fernando, pela ótima convivência e colaboração em todo momento.

Ao Instituto Agronômico Nacional, por ter-me concedido afastamento durante todo este tempo. 


\section{SUMÁRIO}

Página

LISTA DE FIGURAS........................................................................... viii

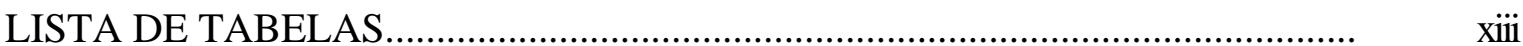

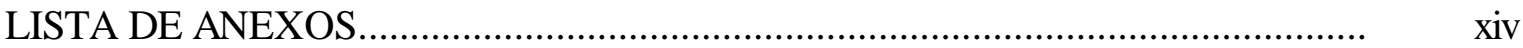

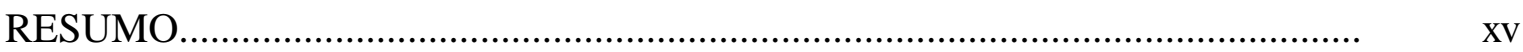

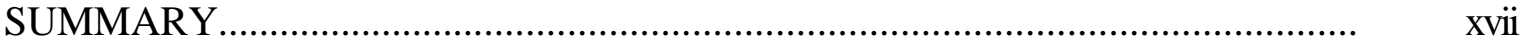

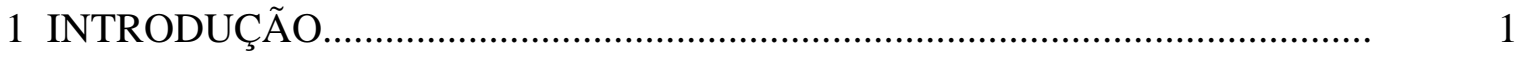

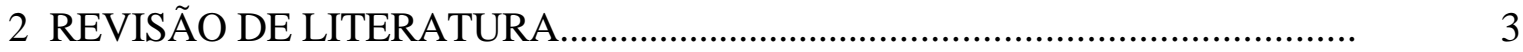

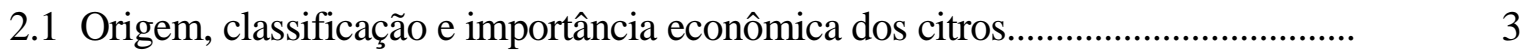

2.2 Utilização racional da água de irrigação............................................................ 5

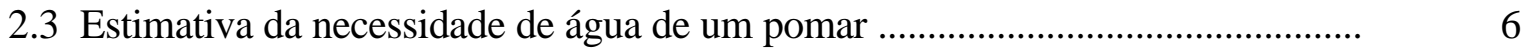



2.3.2 Estimativa da transpiração pelo método da sonda de dissipação de calor............ 12

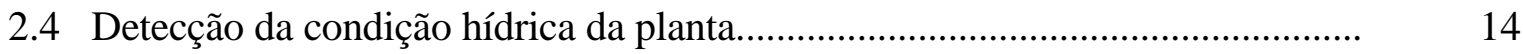

3 MATERIAL E MÉTODOS......................................................................... 18

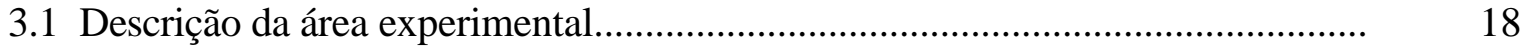

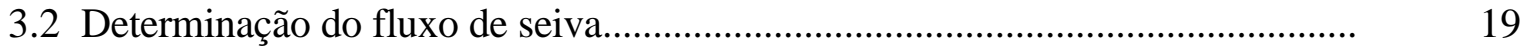


3.2.1 Método de balanço de calor.

3.2.1.1 Princípios do método.

3.2.1.2 Avaliação do desempenho do método de balanço de calor em plantas adultas

3.2.2 Método de sonda de dissipação de Calor

3.2.2.1 Princípios do método.

3.2.2.2 Avaliação do método da sonda de dissipação de calor

3.3 Determinação das variações micrométricas do diâmetro de ramos e caules por dendrometria de precisão.

3.3.1 Descrição e características técnicas do dendrômetro.

3.3.2 Avaliação do desempenho do dendrômetro de precisão e das variações micrométricas.

3.4 Avaliação das condições hídricas das plantas.

3.5 Relação entre a variação radial do caule e o déficit hídrico em plantas jovens

4 RESULTADOS E DISCUSSÃO.

4.1 Determinação do fluxo de seiva

4.1.1 Avaliação do desempenho do método de balanço de calor em plantas adultas...

4.1.2 Avaliação do desempenho do método de dissipação térmica e comparação com o método de balanço de calor em plantas adultas

4.1.3 Avaliação do desempenho do método de dissipação térmica por comparação com as medidas lisimétricas.

4.1.4 Considerações sobre o uso de métodos de fornecimento de calor ao caule/ramo na determinação do fluxo de seiva em citros.

4.2 Transpiração relativa e variação radial do caule/ramo como indicadores das 
condições hídricas das plantas cítricas

4.2.1 Análise preliminar do desempenho do dendrômetro de precisão.

4.2.2 Transpiração relativa e variação radial do caule e de ramos

4.2.2.1 Cálculo da transpiração relativa....................................................................

4.2.2.2 Variação do potencial mátrico da água do solo...............................................

4.2.2.3 Relação entre a amplitude diária de contração e a transpiração relativa das plantas jovens.

4.2.2.4 Exemplos entre a evolução do diâmetro máximo do ramo (DMax) e a transpiração relativa (TRR)

4.2.2.5 Relação entre a evolução do diâmetro mínimo do ramo (DMin) e a transpiração relativa (TRR)

4.2.2.6 Análise da evolução temporal da transpiração relativa e do diâmetro do caule e de ramos

4 2.2.7 Discussão sobre o uso da transpiração relativa e dos parãmetros dendrométricos na determinação das condições hídricas de plantas cítricas....

5 CONCLUSÕES

ANEXOS 


\section{LISTA DE FIGURAS}

1 Esquema do princípio do método de balanço de calor e do sensor para determinação de fluxo de seiva.

2 Esquema do sensor de Granier inserida perpendicularmente no tronco de uma árvore. Observa-se a conexão dos termopares ao sistema de aquisição de dados e da sonda superior a uma fonte de energia

3 (a) Lima ácida "Tahiti" jovem plantada num lisímetro de pesagem coberto com plástico para medir apenas a transpiração da planta. Também é observado o sensor fluxo de seiva por dissipação de calor colocado na base do tronco e os tensiômetros para controle de irrigação. (b) Ramo de uma planta adulta de lima "Tahití" onde foram colocados dois tipos de sensores de fluxo de seiva, o de balanço de calor (MBC) e o de sonda de dissipação térmica (SDT)

4 Esquema detalhado de um dendrômetro da marca Dynamax instalado num ramo..

5 Visão esquemática do experimento no pomar de plantas jovens. Observa-se os sensores instalados em cada planta, as plantas isoladas e os dois lisímetros que foram utilizados para testar o método de fluxo de seiva.

6 Uma planta com o sensor de fluxo de seiva, dendrômetro e tensiômetros instalados, no começo (a) e no final do experimento (b). Ver a diferença de crescimento

7 Medidas térmicas envolvidas na medida de fluxo de seiva pelo método de balanço de calor (veja figura 2). Medidas realizadas num ramo de lima ácida 'Tahiti' entre o 31 de agosto a 13 de setembro (DJ= 243 - 256) de 2001. Fazenda Areão, ESALQ/USP.

8 Variação da taxa de fluxo de seiva (FS) e da evapotranspiração de referência (ETo), estimada pelo método de Penman-Monteith, ao longo do dia. Correspondente à 
planta 1, ramo 1, de lima ácida 'Tahiti', medida no dia 5 de setembro de 2001. Fazenda Areão, ESALQ/USP

9 Variação do fluxo de seiva (FS) e da evapotranspiração potencial (ETo), correspondente à planta 1, ramo 1, de lima ácida 'Tahiti', medidas entre os dias 9 e 11 de setembro de 2001 (DJ=252-254). Fazenda Areão, ESALQ/USP

10 Relação entre a transpiração (fluxo de seiva) medida pelo método de balanço de calor e o diâmetro do ramo em plantas adultas

11 Relação entre o diâmetro e a área foliar de três ramos de lima ácida 'Tahiti', medidos durante o mês de outubro de 2002. Fazenda Areão, ESALQ/USP..........

12 Variação do fluxo de seiva em 3 plantas adultas de lima ácida 'Tahiti', com 5, 3 e 4 ramos, respectivamente; medidas realizadas ao longo dos dias 17, 18 e 19 de outubro de 2002. Fazenda Areão, ESALQ/USP. Determinado pelo método de dissipação térmica.

13 Variação do fluxo de seiva em uma planta adulta de lima ácida 'Tahiti', com 4 ramos, medidas realizadas ao longo dos dias 17, 18 e 19 de outubro de 2002. Fazenda Areão, ESALQ/USP. Determinado pelo método de dissipação térmica..

14 Relação entre medidas de fluxo de seiva (L/dia) realizadas pelo método de balanço de calor e pelo método de dissipação de calor. Medidas realizadas num ramo de lima ácida 'Tahiti' durante 33 dias. Fazenda Areão, ESALQ/USP.

15 Variação das medidas de fluxo de seiva (L/20min), pelos métodos de balanço de calor e de dissipação de calor, realizadas num ramo de lima ácida 'Tahitî', entre 23 e 27 de outubro de 2002. É mostrada, também, a variação da radiação líquida sobre gramado. Fazenda Areão, ESALQ/USP

16 Comportamento do gradiente térmico natural $\left({ }^{\circ} \mathrm{C} / 10 \mathrm{~cm}\right)$, medido em dois ramos de plantas adultas de lima ácida 'Tahiti', em relação ao comportamento da radiação líquida (Rn). Fazenda Areão, ESALQ/USP..... 
líquida (Rn). Fazenda Areão, ESALQ/USP

17 Relação entre a transpiração diária, medida através de lisímetros, e o fluxo de seiva, medido pelo método de dissipação de calor, de duas plantas jovens, com 1,78 e $3,12 \mathrm{~m}^{2}$ de área foliar, respectivamente, de 17 a 28 de agosto de $2002 \ldots . .$.

18 a) Variação da diferença de temperatura do caule nas extremidades do segmento aquecido $(\mathrm{Tc}-\mathrm{Tb})$ considerando-se ou não o gradiente térmico natural mostrado. b) Variação da medida do fluxo de seiva em planta jovem com 3,12 $\mathrm{m}^{2}$ de área foliar, nos dias 21 e 22 de agosto de 2002

19 Evolução temporal da taxa de transpiração (TR), medida através de dois lisímetros de pesagem, e do fluxo de seiva (FS), medido através do método de dissipação de calor em duas plantas jovens (P7 e P8) com 1,78 e 3,12 $\mathrm{m}^{2}$ de área foliar, respectivamente, entre os dias 18 e 28 de agosto de 2002. Fazenda Areão, ESALQ/USP

20 Evolução da variação radial do diâmetro de ramo de lima ácida 'Tahiti' em resposta às chuvas registradas entre o 21 de março $(D J=80)$ e 15 de maio $(D J=135)$ de 2000. Fazenda Areão, ESALQ-USP.

21 Variação radial do diâmetro do ramo de lima ácida 'Tahiti' em resposta à taxa da radiação solar global. Registrado entre 26 e 31 de março (DJ=85-90) de 2000 (dados médios de intervalos de 15 minutos). Fazenda Areão, ESALQ/USP.

22 Variação radial do diâmetro do ramo de lima ácida 'Tahiti' em resposta à temperatura $\left({ }^{\circ} \mathrm{C}\right)$ e umidade relativa do ar (\%). Fazenda Areão. ESALQ/USP, 26 a 31 de março (DJ=85-90) de 2000 (dados médios de intervalos de 15 minutos)..

23 Evolução da variação média diária do diâmetro de dois ramos de diâmetros diferentes $(3,4$ e $6,5 \mathrm{~cm})$ entre os dias 6 de abril $(\mathrm{DJ}=98)$ e 15 de maio $(\mathrm{DJ}=135)$ de 2000 .

24 Evolução dos parâmetros dendrométricos do ramo de uma planta adulta ao longo de 
um período de 56 dias, de 21 de março a 15 de maio (DJ=80-135) de 2000; a) evolução do diâmetro de um ramo; b) evolução do diâmetro médio (ED), amplitude diária de contração (ADC) e evolução do diâmetro máximo (DMax), c) evapotranspiração potencial (ETo) e precipitação; d) deficiência hídrica no solo (baseada no balanço hídrico)

25 Relação entre a área efetiva de condução da seiva $\left(\mathrm{m}^{2}\right)$ e a data, expressa em dias juliano (DJ)

26 Relação entre a área foliar da planta $\left(\mathrm{m}^{2}\right)$ e a data, expresso em dias juliano (DJ)..

27 Variação temporal do potencial mátrico da água do solo no pomar adulto, no ano de 2002. Os valores representam médios de quatro medidas em cada profundidade. As setas com rótulos indicam dias e quantidade de irrigação e de ocorrência de chuva.

28 Variação temporal do potencial mátrico da água em profundidades (legenda, em m) no solo nas plantas 1, 2 e 3 do pomar jovem usadas nas determinações de fluxo de seiva e dendrométricas. As setas indicam irrigação e/ou chuva, cujos valores se encontram no Anexo 10

29 Variação temporal do potencial mátrico da água em 4 profundidades (legenda, em m) no solo nas plantas 4, 5 e 6 do pomar jovem usadas nas determinações de fluxo de seiva e dendrométricas. As setas indicam irrigação e/ou chuva, cujos valores se encontram no Anexo 10

30 Relação entre a amplitude diária de contração e a transpiração relativa em seis plantas jovens de lima ácida.

31 Exemplos da variação radial do diâmetro do tronco de limoeiro, indicando valores diferentes de ADC para igual valor de TRR (a) e indicando iguais valores de ADC para diferentes valores de TRR (b).

32 Relação entre a variação do diâmetro máximo (DMax) e a transpiração relativa 
(TRR) em seis plantas.

33 Evolução da variação radial do diâmetro do caule de duas plantas de lima ácida (P1 e P2) durante dois dias consecutivos. P1 corresponde à duas situações em que ocorreu deficiência hídrica, $\mathrm{TRR}=0,8$, com diferentes valores de DMax. P2 corresponde à duas situações em que não há indicação de deficiência hídrica, $\mathrm{TRR}=1$, e com diferentes valores de DMax

34 Relação entre a evolução do diâmetro máximo (DMin) e a transpiração relativa (TRR) em seis plantas

35 Variação radial de ramo de duas plantas adultas de lima ácida 'Tahiti' ao longo dos dias juliano 293 a 344 de 2002. As setas indicam as lâminas de chuva e volume de água de irrigação, conforme os rótulos

36 Evolução ao longo do tempo, do diâmetro máximo de ramos de duas árvores de lima ácida 'Tahiti' entre os dias julianos 293 e 344 de 2002

37 Evolução temporal do diâmetro máximo do caule e da transpiração relativa (TRR) de duas plantas jovem de lima ácida 'Tahiti' (plantas 1 e 2)

38 Evolução temporal do diâmetro máximo do caule e da transpiração relativa (TRR) de duas plantas jovem de lima ácida 'Tahiti' (plantas 3 e 4)

39 Evolução temporal do diâmetro máximo do caule e da transpiração relativa (TRR) de duas plantas jovem de lima ácida 'Tahiti' (plantas 5 e 6)

40 Aumento do diâmetro médio do caule de uma planta jovem e uma planta adulta de lima ácida 'Tahiti', com tamanho aproximado de $4 \mathrm{~cm}$, durante o ano 2002. Fazenda Areão, ESALQ/USP. As linhas pontilhadas indicam estimativa em períodos em que as medidas não foram realizadas 


\section{LISTA DE TABELAS}

1 Valores de transpiração (fluxo de seiva) diários $\left(\mathrm{L} \mathrm{d}^{1}\right)$ medidos em duas plantas adultas de lima ácida 'Tahiti', com 4 ramos cada uma, determinados através do método de balanço de calor, no período compreendido entre 31 de agosto e 13 de setembro de2001 (dias juliano DJ, entre 243 e 256)

2 Diâmetro e área foliar $(\mathrm{AF})$ dos ramos $\left(\mathrm{R}_{\mathrm{i}}\right)$ correspondente a 4 plantas de lima ácida Tahiti. AF determinado através da equação linear da Figura 11

3 Fluxo de seiva determinado pelo método de dissipação térmica, em quatro plantas de lima ácida 'Tahiti', durante três dias. Fazenda Areão, ESALQ/USP. 2002...........

4 Medidas comparativas da transpiração diária de duas plantas medida através de lisímetros de pesagem (TR) e do fluxo de seiva (FS). Diferença relativa (DR) calculada em base na medida lisimétrica. $\mathrm{DR}=(\mathrm{FS} / \mathrm{TR}) / \mathrm{TR} * 100(\%)$....................

5 Diâmetro do tronco (D) e área efetiva de condução de seiva (AE) de 6 plantas.....

6 Área foliar, $\mathrm{em} \mathrm{m}^{2}$, de 7 plantas medidas entre julho e novembro de 2002..............

7 Valores de temperatura média (Tmed), umidade relativa média (UR), radiação soloar global (RG), radiação líquida (RN), evapotranspiração potencial (ETp) e do potencial matricial (PM) médio na planta 1 (P1) nos dias 2 e 14 de setembro de 2002 


\section{LISTA DE ANEXOS}

1 Calendário Juliano

2 Dados agrometeorológicos do mês de agosto de 2002. Fazenda Areão, ESALQ, Piracicaba/SP.

3 Dados agrometeorológicos do mês de setembro de 2002. Fazenda Areão, ESALQ, Piracicaba/SP

4 Dados agrometeorológicos do mês de outubro de 2002. Fazenda Areão, ESALQ, Piracicaba/SP.

5 Dados agrometeorológicos do mês de novembro de 2002. Fazenda Areão, ESALQ, Piracicaba/SP

6 Transpiração diária (L/planta), medido através do método de dissipação de calor no período entre 17 de agosto (229) e 16 de novembro (320) de 2002

7 Amplitude diária de contração do ramo (ADC) e transpiração relativa da planta (TRR).

8 Variação do diâmetro máximo (DMax) e transpiração relativa da planta (TRR).

9 Valores da evolução do diâmetro mínimo (DMin) e transpiração relativ.a da planta (TRR).

10 Calendário de irrigação (L/planta) e de chuva (mm) das plantas jovens durante o trabalho experimental desenvolvido durante 2002. 


\section{AVALIAÇÃO DO USO DO FLUXO DE SEIVA E DA VARIAÇÃO DO DIÂMETRO DO CAULE E DE RAMOS NA DETERMINAÇÃO DAS CONDIÇÕES HÍDRICAS DE CITROS, COMO BASE PARA O MANEJO DE IRRIGAÇÃO}

Autor: JUAN SINFORIANO DELGADO ROJAS

Orientador: Prof. Dr. LUIZ ROBERTO ANGELOCCI

\section{RESUMO}

Uma dificuldade para o manejo adequado da irrigação em espécies de plantas perenes, como por exemplo num pomar, é determinar o momento e a quantidade de água que deverá ser aplicada. Há vários métodos tradicionais de medida de consumo diário de água, assim como indicadores do déficit hídrico, mas cada um apresenta seu grau de dificuldade de uso no campo que levam, às vezes, à aproximações pouco exatas. Diante destes problemas e levando em consideração a importância dos citros na economia nacional, o presente trabalho teve dois objetivos principais: a) avaliar dois métodos de determinação de fluxo de seiva para a estimação da taxa de transpiração diária de plantas de lima ácida 'Tahiti' e, b) avaliar o uso da contração radial do ramo ou caule (utilizando um dendrômetro de precisão) e da transpiração relativa da planta (estimada a partir do fluxo de seiva), como indicadores vegetais diretos de deficiência hídrica. Para atingir estes objetivos, foram instalados experimentos em dois pomares, um de plantas jovens e outro de plantas adultas, de lima ácida 'Tahiti'. Os métodos de determinação da transpiração (fluxo de seiva) foram o de balanço de calor (BC) e o da sonda de dissipação térmica (SDT). A comparação entre os dois métodos em um ramo 
de uma planta adulta, e a comparação do SDT com medidas lisimétricas em plantas jovens, demonstrou o bom desempenho de ambos e sua possibilidade de uso na quantificação da transpiração em citros, principalmente como subsídio à irrigação localizada. No BC há necessidade de precauções para minimizar erros devidos à variações espúrias que os valores de fluxo de seiva sofrem ao longo do período matinal ou de superestimativas no período noturno. No caso da SDT, uma fonte de erro que causa subestimativa é a ocorrência de gradiente térmico natural no caule/ramos nas regiões de medida da sonda, com necessidade de corrigir o erro para medidas mais acuradas. A SDT mostra-se uma técnica confiável e de vantagens em relação ao BC, pela menor complexidade e custo. As variáveis dendrométricas do caule/ramos, recomendadas na bibliografia como indicadoras de estresse hídrico (variação da amplitude diária de contração, da diferença em dias subsequentes do diâmetro máximo e do diâmetro mínimo), mostraram-se problemáticas, pela complexa relação que apresentam com a disponibilidade hídrica no solo, demanda evaporativa do ar e tamanho do caule. A análise da evolução do diâmetro máximo diário e, também, do diâmetro médio mostrou potencialidade de uso como técnica indicadora de estresse hídrico. No entanto, recomenda-se estudos mais aprofundados que considerem regimes hídricos do solo diferenciados e com imposição de secagem mais acentuada, além de se levar em conta características próprias de resposta de espécies cítricas à disponibilidade hídrica do solo e à demanda atmosférica. A transpiração relativa, expressa pela relação entre a transpiração atual e a transpiração máxima (calculada por unidade de área foliar), guardou relação com a variação da disponibilidade hídrica do solo, mas comparada à análise da evolução do diâmetro máximo do caule, mostrouse menos estável. 


\section{EVALUATION OF THE USE OF SAP FLOW AND THE VARIATION OF STEM AND BRANCHES DIAMETER IN THE DETERMINATION OF CITRUS WATER STATUS, AS A BASE FOR IRRIGATION}

Author: JUAN SINFORIANO DELGADO ROJAS Adviser: Prof. Dr. LUIZ ROBERTO ANGELOCCI

\section{SUMMARY}

A difficulty for the appropriate handling of irrigation of perennial plants like orchards is to determine the moment when and the amount of water that should be applied. There are several traditional methods to determine water consumption, as well as indicators of water stress. However, they all have difficulties when used in the field because their approaches are not very accurate. Taking into consideration these problems and the importance of citrus in the economy of the state of São Paulo, the present work had two main objectives: a) to evaluate two methods for the estimation of sap flow in the determination of the daily rate of transpiration of plants of 'Tahiti' lime and b) to evaluate the use of the variation of the stem/branches diameter (by using a precision dendrometer) and the relative transpiration (estimated starting from the sap flow) as direct plant indicators of water stress. To reach these objectives, experiments were set up in two orchards of 'Tahiti' lime, one of young plants and another of adult plants. The methods for the determination of the transpiration (sap flow) were: the heat balance method (HBM) and the heat dissipation probe method (HDPM). The comparison between the two methods in a branch of an adult plant and the comparison of HDPM with lisimeter measurements in young plants demonstrated the accuracy of both methods for the 
quantification of the transpiration in citrus, mainly as a tool for located irrigation. With HBM, precautions should be taken to minimize errors due to spurious variations of sap flow values along the morning or overestimation of the values during night. With HDPM, the occurrence of a natural thermal gradient in the branch or stem is an error source that causes underestimation and that should be taken into account for accurate estimations. HDPM has shown to be a reliable technique with advantages over HBM for its less complexes and lower cost. The use of dendrometric variables of the stem (the variation of the daily contraction, the maximum diameter and the minimum diameter), in the literature recommended as ndicative of water stress, is problematic because of the complex relationship that they have with the soil water status, the atmospheric water demand and the size of the stem. The analysis of the evolution of the daily maximum diameter and also, of the mean diameter are potential indicative techniques of plant water stress. However, more profound studies under different soil moisture regimes, with imposition of severe drying of the soil, that also take into account specific response characteristics of citrus species to the soil water status and the atmospheric water demand are needed. The relative transpiration (RT), expressed by the relationship between the current transpiration and the maximum transpiration (calculated by unit of leaf area), was related to the soil water status variation. However, its relation with the analysis of the evolution of the maximum diameter of the stem was less stable. 


\section{INTRODUÇÃO}

A fruticultura, dentro dela a citricultura, destaca-se como uma importante atividade econômica do pais, capaz de promover e viabilizar o desenvolvimento de diversas regiões. Neste contexto, a irrigação é um fator decisivo na maximização da produção e qualidade dos produtos, obrigando os produtores adotarem este sistema para garantir sua competitividade. Por outro lado, verifica-se a necessidade de implantação de medidas que venham a racionalizar o uso de água na agricultura, levando em conta que mundialmente este setor é o maior usuário desse recurso natural.

Uma aplicação eficiente de água não envolve somente equipamentos modernos, mas também um manejo adequado do sistema de irrigação, isto é uma aplicação precisa do volume com uma freqüência justa para que nem falte nem exceda a quantidade que a planta necessita para seu ótimo desenvolvimento.

Para um manejo adequado e eficiente da irrigação, é indispensável dispor de informações sobre a condição hídrica do solo e da evapotranspiração máxima da cultura. Em culturas perenes, em um pomar com grande espaçamento entre árvores, de maneira que a planta é considerada "isolada", o problema é determinar o momento de irrigação e o volume de água a ser aplicado por planta em cada período de tempo. O problema ocorre pois, apesar dos numerosos trabalhos já realizados, não se tem um indicador confiável e prático que possa ser utilizado sem incorrer em grandes erros.

Sendo os citros de grande importância econômica, existem numerosos estudos realizados a respeito do ponto crítico de umidade do solo e do uso consuntivo da água, mas os resultados são poucos conclusivos, o que mostra a necessidade de realizar estudos locais para tentar oferecer uma ferramenta prática ao manejo da irrigação. 
Têm sidos desenvolvidos e testados numerosos métodos capazes de determinar diretamente a quantidade de água consumida por uma planta lenhosa de tamanho relativamente grande, como no caso de uma planta cítrica adulta. Entre eles, há dois métodos térmicos conhecidos como de "balanço de calor" e de "dissipação de calor" que vêm recebendo grande atenção nos últimos tempos por utilizarem princípios físicos relativamente simples e poderem ser aplicados diretamente no campo sem alterar as condições fisiológicas e microclimáticas da planta.

Quanto à determinação do ponto crítico de umidade do solo em uma cultura, pela dificuldade de se utilizar parâmetro do solo como a tensão de água, há quem utilize experimentalmente sensores que detectam reações fisiológicas ou anatômicas da planta ao déficit hídrico. Neste caso pode-se citar o dendrômetro de precisão, também conhecido como LVDT (Linear Variable Displacement Transducers), que mede a contração radial do tronco em resposta às condições hídricas da planta, impostas pelas condições meteorológicas e pela disponibilidade de água no solo.

A combinação das medidas de variação radial dos ramos e da taxa de transpiração da planta, pode resultar em uma ferramenta importante na prática da irrigação em pomares de plantas cítricas. Para tanto, definiu-se como objetivo deste trabalho, determinar a transpiração de citros através dos dois métodos térmicos de determinação de fluxo de seiva e identificar um parâmetro da contração radial de ramos que possa ser utilizado como indicador do déficit hídrico a partir da relação desse parâmetro com a transpiração e da disponibilidade hídrica no solo. Na prática, esse conhecimento poderia ajudar a estender ao máximo o turno de rega e, por consequiência, poderia otimizar os materiais na hora de dimensionar o sistema, reduzir custos de implantação e economizar tempo e energia durante o manejo. 


\section{REVISÃO DE LITERATURA}

\subsection{Origem, classificação e importância econômica dos citros}

As plantas cítricas são originárias das regiões tropicais e subtropicais da Ásia e do arquipélago Malaio, estendendo-se desde a Índia, o norte da China, a Nova Guiné até a Austrália (Simão, 1998). A primeira espécie conhecida pelos europeus foi a cidra (Citrus medica), mencionada por Teofrasto, 300 a.C, enquanto que a laranja doce foi uma das últimas levada para o continente europeu por volta do século XV (Malavolta \& Netto, 1989). Elas foram introduzidas na América pelos espanhóis e portugueses no século XVI (Simão, 1998).

Apesar de serem consideradas frutas tropicais, os citros demonstram também boa adaptação nas regiões temperadas com inverno pouco rigoroso, podendo-se encontrá-los na atualidade quase em todos os países do mundo.

Os citros pertencem à família Rutaceae, sub-família Aurantioideae, tribo Citrae, subtribo Citrinae, sendo os principais gêneros: Fortunella, Poncirus e Citrus. O gênero Citrus engloba quase a totalidade das espécies comerciais cultivadas como as laranjas doces (C. sinensis Osbeck), tangerinas e mexericas (C. reticulata Blanco), limas ácidas $(C$. aurantifolia S.), lima Tahiti (C. latifolia Tanaka), limões verdadeiros (C. limon Burn) e pomelos (C. paradisi Macf) (Simão, 1998).

Com plantios acima de 1.100.000 hectares, os citros têm grande importância comercial no Brasil, sendo São Paulo o maior estado produtor com aproximadamente $70 \%$ da produção nacional (FAO, 2001). Essa importância é demonstrada pelo valor comercializado no mercado exterior; a laranja por exemplo, em forma de suco concentrado, representou um ingresso bruto de US\$1.235.005.000 no ano de 1999 (Saturnino, 2001). Os resultados das exportações brasileiras de frutas no ano 2000, divulgados pela Secretaria do Comércio Exterior do Ministério de Desenvolvimento da Indústria e do Comércio (Saturnino, 2001), 
revelam que a laranja, como fruta fresca, ocupa a quinta posição entre as principais frutas brasileiras de exportação, representando um ingresso bruto de US\$ 15.248.000 no ano 2000, enquanto que o limão e a lima ácida ocuparam a nona posição, representando o valor de US\$ 4.642.000.

Apesar da destruição de grandes áreas de plantações de citros em plena produção, devido aos focos de ocorrência da clorose variegada dos citros (CVC) e do cancro cítrico, a taxa atual de implantação de novos pomares é bem maior. Um dos motivos desta atitude é a diminuição da colheita na Flórida (EUA), devido as secas e geadas ocorridas durante a safra de 2000/2001 (Tozatti, 2001). Os produtores norte-americanos, segundo o mesmo autor, ainda foram prejudicados pelo baixo preço e pelo problema crescente de doença como a tristeza. Este panorama foi suficiente para se especular que o desânimo generalizado desses produtores poderia acarretar a diminuição da área plantada naquele país, beneficiando os produtores brasileiros.

Outro motivo que sugere um aumento ainda maior da área plantada no Brasil é o fechamento de contratos antecipados entre as fábricas de processamento e produtores, antes mesmo de começar a safra de 2001 (Boteon \& Vidal, 2001). Este fato contribuiu na redução da oferta no mercado interno, o que ajudou a alcançar um maior preço nos últimos seis anos (Boteon \& Vidal, 2001).

A iminente redução de subsídios às exportações de parte dos países desenvolvidos a partir de 2005, conforme o compromisso subscrito e assinado pelos membros da Organização Mundial de Comercio (OMC) na reunião realizada no ano passado em Qatar, também é um aliciante ponderável para quem pensa no aumento da produção de citros (Moreira, 2002).

Segundo Pimentel (2002), impulsionado por todas essas perspectivas, há quem, com visão futurista, já está começando a plantar grandes superfícies de citros no Estado de Roraima, estendendo desta maneira a fronteira de produção de espécies cítricas. 
Mais do que aumentar a superfície plantada, os produtores terão que se preocupar, também, do aumento de produtividade por superfície. "Falar em irrigação de citros em nossas condições é sempre complexo e polêmico. Complexo, devido aos poucos trabalhos de pesquisa realizados em nossas condições, a irrigação é feita com pouco suporte científico; polêmico, pois sem tais conhecimentos, a discussão fica muitas vezes baseada na experiência de cada produtor" (Corte, 2001).

Enquanto cerca de $45 \%$ da produção mundial de citros provém de pomares irrigados onde a produtividade é considerada alta (Zanini et al., 1998), no Brasil, apesar de ostentar o primeiro lugar na produção mundial com aproximadamente $22 \%$ do total, a maioria dos pomares não são irrigados e apresentam produtividade considerada baixa, com apenas 2 caixas por planta (Amaro et al, 1997); tudo isto faz acreditar que a prática da irrigação em pomares de cítros irá aumentar indiscutivelmente.

\subsection{Utilização racional da água de irrigação}

A necessidade de garantir uma maior produtividade, obriga os citricultores a adotarem novos sistemas de produção, entre eles a aplicação da irrigação.

Por outro lado, verifica-se a necessidade de implantação de medidas que venham a racionalizar o uso da água, levando em conta que mundialmente a agricultura é de longe o maior usuário, representando $69 \%$ da demanda contra $23 \%$ da indústria e $8 \%$ do abastecimento humano (Bonganha, 2001).

A utilização racional de água de irrigação depende diretamente do grau de disponibilidade desse recurso. Em alguns países como na África do Sul e Estados Unidos, na irrigação de citros prevalece o sistema de irrigação por aspersão, com pivô central ou autopropelido (Zanini et al, 1998), enquanto que na Espanha e Israel prevalece o sistema localizado (Shalhevet \& Levy, 1990). Neste último país, a escassez de água para irrigação é tanta que, nos últimos anos é cada vez mais freqüente observar áreas abandonadas de citros 
por falta de irrigação e, de acordo com (Christofidis, 2001), pressupõe-se que em pouco tempo a tendência será similar na Espanha.

No Brasil tem aumentado consideravelmente as áreas agrícolas e, consequentemente, as áreas irrigadas. Apesar do país contar com sistemas hidrográficos abundantes, a concorrência na utilização deste bem em áreas produtoras e de alta concentração populacional ou com problemas desse recurso, levou o governo federal criar a Agência Nacional de Águas (ANA), para velar sobre a utilização racional da água. A instituição aplicará taxas sobre o volume de consumo, semelhante ao que já ocorre em países como Estados Unidos, Chile, México e França na área de irrigação (Saturnino, 2000).

Esta decisão obrigará os produtores locais a diminuir o uso de sistemas de irrigação de baixa eficiência, como os de tipo aspersão, o mais utilizado em pomares de laranjeira (Vieira, 1995), e adotar sistemas de maior eficiência de aplicação, como os de tipo localizado.

\subsection{Estimativa da necessidade de água de um pomar}

Irrigar envolve a aplicação artificial de água em quantidades adequadas e com determinadas frequiências, dirigidas por fatores de solo, clima e da própria cultura. "O quando, quanto e como irrigar devem ser respondidos com base em parâmetros locais determinados pela pesquisa, e não apenas generalizando práticas específicas que tiveram sucesso em outras condições" (Costa \& Coelho, 2001).

A quantidade de água a ser aplicada é calculada com base na evapotranspiração máxima da cultura, enquanto que a freqüência depende diretamente da quantidade de água retida na camada de solo ocupado pelo sistema radicular e a facilidade com que a planta absorve essa água.

Quando se trabalha com culturas que cobrem de forma descontínua a superfície do solo, como num pomar de citros, as plantas podem ser tratadas de forma individualizada, no que se refere ao consumo de água. Neste caso, em razão da economia de água, a irrigação de 
pomares deve utilizar métodos de fornecimento localizado; para tanto, o conhecimento da transpiração de cada árvore assim como o momento de irrigar é fundamental.

Existem numerosos métodos para estimar o consumo de água por uma cultura. Além da lisímetria, utilizada quase que exclusivamente em pesquisas, a estimativa pode ser realizada com base em cálculos da evapotranspiração de referência (ETo) com ajuste pelo coeficiente de cultura (kc), determinado pela fase de crescimento (Doorenbos \& Pruitt, 1997). A evapotranspiração de eferência é, conceitualmente, aquela que ocorre em uma cobertura vegetal extensa, de baixo porte $(8-12 \mathrm{~cm})$, cobrindo totalmente o solo, em crescimento ativo e sem ocorrência de deficiência hídrica, de forma que seus valores são dependentes das condições atmosféricas; sua estimativa pode ser feita a partir de dados meteorológicos medidos em condições padronizadas.

Inúmeros métodos de estimativa climatológica de ETo tem sido propostos, sendo que Zanini et al. (1998) citam ser o do tanque classe A o mais usado. Na última década, trabalhos patrocinados pela FAO (Allen et al., 1989; Smith et al. 1992) sugerem que o método mais adequado para a estimativa na escala diária é o de Penman - Monteith, parametrizado segundo a proposta contida em tais trabalhos.

Através do valor de ETo, é possível estimar a evapotranspiração de uma cultura pelo uso dos coeficientes culturais, na forma porposta por Doorembos \& Pruitt (1997) e Smith et al. (1992). No caso de coberturas "descontínuas", como os pomares, a transposição de ETo para evapotranspiração da cultura (ETc) apresenta alguma dificuldade, principalmente na irrigação localizada, pois somente uma parte do solo é ocupado pelas plantas e somente parte do mesmo será molhado. Nesse caso, recomenda-se a utilização de um fator Kr sugerido por Keller \& Karmeli ${ }^{1}$, citados por López et al. (1992), que é aplicado ao cálculo do consumo diário por planta, pela expressão $\mathrm{Kr}=\% \mathrm{AC} / 0,85$, sendo $\% \mathrm{AC}$ a porcentagem de área coberta pela projeção da copa. Assim o volume V a ser aplicado (L/planta) é calculado

${ }^{1}$ KELLER, J.; KARMELI, D. Trickle irrigation design. Glendora: Rain Bird, 1974. 133p. 
multiplicando ETo por $\mathrm{Kc}$ e $\mathrm{Kr}$ e dividindo-se o valor resultante por A e Ea, sendo A a área ocupada pela planta e Ea a eficiência de aplicação.

Entretanto, o uso desse coeficiente $\mathrm{Kr}$ representa uma aproximação muito grande, pois a transpiração é função da área foliar, que deveria ser a variável utilizada preferencialmente na estimativa de consumo hídrico. Como a determinação da área foliar apresenta dificuldade, principalmente em árvores, tem se preferido o uso da cobertura do solo pela copa. Uma alternativa proposta é o uso do modelo de Penman - Monteith adaptado para espécies lenhosas, como realizado por Landsberg et al. (1975), Thorpe (1978), Green (1993), Angelocci (1997) e Marin (2000), em várias frutíferas. Embora o modelo seja climatológico, com medidas de campo relativamente simples, a dificuldade de sua aplicação reside no fato de que ele exige a determinação da área foliar e, além disso, a determinação de variáveis como as resistências à difusão de vapor da copa e da camada adjacente, bem como do saldo de radiação da copa.

Por esses motivos, a utilização racional de água na prática da irrigação tem levado pesquisadores a desenvolverem métodos mais diretos de medidas para determinar com maior exatidão o consumo de água por uma cultura, principalmente em plantas lenhosas de tamanho relativamente grande, como no caso de uma planta cítrica. A maioria destes métodos envolvem medidas físicas que permitem estimar diretamente a transpiração por planta, como na utilização de câmaras gasosas au pelo uso de traçadores radioativos, mas há restrições teóricas e práticas ao seu emprego (Angelocci, 1995).

Nos denominados métodos térmicos, mede-se diretamente o fluxo de seiva que passa por um determinado segmento do tronco, utilizando princípios físicos relativamente simples. Eles podem ser aplicados diretamente no campo sem alterar as condições fisiológicas e microclimáticas da planta durante a medida. Um desses métodos utiliza pulsos intermitentes de calor (Cohen et al., 1981; Cohen \& Fuchs, 1989; Cohen et al., 1990, Green et al., 1997; Nadezhdina, 2000). Outros empregam fornecimento de calor constante em um segmento do tronco, sendo estimados os fluxos condutivos (axiais e radiais) de calor no lenho, deixando-se 
como termo residual o fluxo de calor dissipado convectivamente pela seiva. Este método é conhecido como método de balanço de calor (Sakuratani, 1981). Um método mais simples, descrito por Granier (1985), tem por princípio o fornecimento contínuo e constante de calor a um segmento de um caule ou à ramos. Através da diferença de temperatura em dois pontos do segmento aquecido é possível determinar a velocidade de transporte convectivo da seiva.

\subsubsection{Estimativa da transpiração pelo método de balanço de calor}

O princípio físico que envolve o método de balanço de calor consiste na aplicação de uma potência dissipada na forma de calor em regime constante, num determinado segmento de caule ou tronco. O calor perdido em cada intervalo de tempo, por condução axial e radial, é subtraído da potência fornecida. O resultado dessa subtração representa o calor transportado convectivamente pela seiva, caso o armazenamento de calor no intervalo de tempo seja nulo ou conhecido. O fluxo volumétrico de seiva está associado ao calor transportado convectivamente (Sakuratani, 1981; Valancogne \& Nasr, 1989; Steinberg et al., 1989; Dayau, s.d; Valancogne \& Granier, 1994; Angelocci, 1995).

Os primeiros pesquisadores que utilizaram o método de balanço de calor foram Cermak e colaboradores (1973), que aplicavam taxa de calor variável para manter estável o gradiente da temperatura nas extremidades do segmento de caule adotado para as medidas. Posteriormente, Sakuratani (1981), trabalhando com plantas herbáceas no Japão, empregou um sistema de fornecimento de calor constante. Com isto evitou-se a utilização de um sistema complexo para manter a estabilidade térmica no segmento aquecido. Numerosos autores adotaram este método tanto em plantas herbáceas (Baker \& van Bavel, 1987; Ham \& Heilman, 1990; Cohen et al., 1990; Mangueira \& Silans, 1995), como em plantas lenhosas (Angelocci \& Valancogne, 1993; Braun \& Schmid, 1999; Grime \& Sinclair, 1999; Herzog et al., 1997; Marin, 2000; Nasr, 1989; Steinberg et al., 1989; Steinberg et al., 1990; TrejoChandia, 1997; Valancogne, 1993; Valancogne \& Nasr, 1989; Van Babel, 1993; Weibel \& Vos, 1994). 
Entre as principais fontes de erros observadas por diversos autores, a não consideração do valor do calor armazenado no segmento do tronco aquecido no cálculo do balanço de calor pode se tornar importante em plantas lenhosas de grande porte. Valancogne \& Nasr (1989) mostraram a importância do calor armazenado no tronco em macieiras adultas, enquanto Herzog et al. (1997) observaram o mesmo na Suíça ao medir o fluxo de seiva em Picea abies L. Steinberg et al. (1989) já tinham observado o mesmo problema quando trabalharam com planta lenhosa de menor porte de Ficus benjamina no Texas, EUA. Grime \& Sinclair (1999) assim como Weibel \& de Vos (1994), supõem que a mudança no conteúdo de água no determinado segmento da madeira pode interferir na capacidade de armazenamento de calor; se for assim, o erro pode ser considerável, pois no modelo é utilizado um valor fixo padronizado do calor específico volumétrico da madeira úmida, sendo que esse valor poderia ser variável.

Outra fonte de erro deste método pode ser a inadequada colocação de termopares medidores de variações de temperatura no caule (Mangueira \& Silans, 1995). Quando se trata de planta de grande porte, os termopares utilizados para medir o gradiente axial de temperatura são introduzidos no tronco no interior de um pequeno tubo (sondas). Neste caso a dificuldade para fixar os termopares de forma adequada é muito grande.

Weibel \& de Vos (1994) e Ham \& Heilman (1990) indicaram como possível fonte de erro o insuficiente contato entre o sensor e a superfície do caule. Os primeiros autores afirmaram também terem tido dificuldades para manter a potência de entrada no sistema em forma constante. Outra precaução recomendada por Angelocci (1995) é realizar um bom isolamento térmico para evitar flutuação de temperatura do ambiente e incidência direta de radiação no tronco, próximo ao volume amostrado.

Weibel \& de Vos (1994), trabalhando com macieira, observaram que quando o intervalo de tempo de medida é pequeno, são detectados erros consideráveis entre o fluxo de seiva, medido pelo método de balanço de calor e a transpiração. Estes autores afirmam que em intervalos maiores que 24 horas o erro é de $4 \%$ enquanto que a curto intervalo de tempo 
(30 min), o erro chega a 20\%. Steinberg et al. (1989) também afirmam que em plantas lenhosas, quando as medidas eram integradas em mais de $24 \mathrm{hs}$, o erro pode ser menor a $4 \%$, no entanto, ele foi maior quando as medidas referiam-se a um período de $4 \mathrm{hs}$.

Devitt et al. $^{2}$, citados por Trejo-Chandia (1997), recomendam trabalhar com valores acumulados para períodos superiores a 68 hs para que o erro se mantenha abaixo de $10 \%$. O último autor, comparando esse método com transpiração medida por pesagem em três espécies de plantas, encontrou boa concordância, cerca de $10 \%$ de erro, trabalhando tanto na escala diária como horária.

Outro erro pode ser originado por defeito de construção do sensor, já que apesar da existência de sensores comerciais, por diversos motivos, tais como preço e tamanho para ajustar no tronco, muitos pesquisadores preferem construir seu próprio sensor, podendo haver desconsideração de certos cuidados preconizados na confecção do mesmo (Dayau, s/d).

Conforme Smith \& Allen (1996), o método de balanço de calor, tomando todas a precauções, normalmente estima uma margem de erro abaixo dos $10 \%$.

A principal vantagem deste método é que ele não precisa ser calibrado (Angelocci, 1995).

No momento, esse método ainda é considerado apenas uma ferramenta nas pesquisas e sua aplicabilidade está sendo testada em um número muito grande de espécies. Também estão sendo desenvolvidos estudos para o seu aperfeiçoamento, para melhoria da exatidão das medidas. Localmente, o seu uso em citros foi testado por Trejo-Chandia et al. (1997) e por Coelho Filho (2002) em plantas jovens (diâmetro de caule inferior a 1,8 cm), em comparação com a transpiração medida por pesagem em balança e em lisímetro de célula de carga, enquanto Marin et al. (2002) utilizaram-no em plantas adultas. Todos esses trabalhos foram realizados em lima ácida 'Tahiti', sendo que no último não foi feito um teste direto do seu do seu desempenho. Considerando que a resposta do método depende fundamentalmente da

\footnotetext{
${ }^{2}$ DEVITT, D.A.; BERKOWITZ, M.; SCHULTE, P.I.J. et al. Estimating transpiration for three woody ornamental tree species using stem flow gauges and lysimetri. HortScience, v.28, n.4, p.320-322, 1993.
} 
espécie, pois está associada à morfologia do caule (Backer e Nieber, 1989; Braun \& Schmid, 1999), é recomendável avaliação do seu desempenho em espécie na qual ele não foi ainda testado, principalmente em plantas adultas de citros.

\subsubsection{Estimativa da transpiração pelo método da sonda de dissipação de calor}

O método de dissipação de calor, foi desenvolvido originalmente para medida de fluxo de seiva em espécies florestais por Granier (1985). O autor relacionou a velocidade de dissipação de calor, aplicado num ponto do tronco, com o fluxo de seiva. O método exige fornecimento de uma pequena quantidade de calor de forma constante através de uma sonda de dissipação térmica inserida num ponto do tronco ou caule. A variação temporal da diferença de temperatura entre esse ponto e um ponto abaixo do mesmo $(10 \mathrm{~cm}$ aproximadamente) é ocasionada pelo transporte convectivo de calor pela seiva. Portanto, no período de um dia, a máxima diferença de temperatura entre os dois pontos de medida significa que o fluxo de seiva é mínimo ou nulo, enquanto que a mínima diferença significa uma taxa máxima de fluxo de seiva através dessa área de transporte. A máxima diferença de temperatura acontece normalmente cerca do amanhecer, enquanto que a mínima às 16 horas aproximadamente.

Granier (1985) calibrou o método em laboratório, primeiro com três espécies de plantas lenhosas e posteriormente com seis, verificando que uma única equação de calibração pode ser utilizada para todas elas. Em função disso, propôs que essa equação pode ser usada em qualquer planta lenhosa com diâmetro de caule superior a 4 cm (Smith \& Allen, 1996).

Vários autores já testaram este método em condições naturais de campo em numerosas espécies de plantas lenhosas (Granier \& Bréda, 1996).

Ferreira \& Zitscher (1996) observaram que uma das principais fontes de erro deste método pode ser atribuída ao gradiente natural da temperatura no tronco, principalmente quando o sensor é colocado muito próximo ao solo. Granier (1987) já tinha observado uma diferença entre os valores de fluxo de seiva medidos com três sensores diferentes, orientados 
em lados opostos, com 120 graus em volta do tronco e à altura de $1 \mathrm{~m}$ acima do solo. Loustau et al. (1998) também observaram discrepâncias entre os valores de fluxo de seiva medidos em duas alturas do caule de uma planta de pino, 1,5 e 8,5 m, respectivamente, possivelmente devido à existência desse gradiente natural.

O referido gradiente térmico natural é o efeito da radiação e da temperatura do ar e do solo que atuam no caule, afetando o valor da medida térmica do sensor e que por sua vez acaba afetando significativamente a estimativa do fluxo de seiva.

O modelo implica a determinação da densidade de fluxo de seiva na secção transversal do caule e sua transformação em fluxo de água exige a determinação mais exata possível da área condutiva de seiva no lenho ("xilema efetivo"). A determinação da área efetiva do xilema é uma fonte de erro no método e, ao exigir a retirada de uma amostra do lenho ou a destruição total da planta, torna-se um procedimento desvantajoso desse método em relação ao de balanço de calor. Por outro lado, a grande vantagem do método é a facilidade de confecção e instalação do sensor, quando comparado com outros métodos térmicos (Braun, 1997). Outra fonte de erro é representada pelas variações espaciais da densidade de fluxo de seiva no lenho, que exige a adequada instalação da sonda (Lu et al., 2000).

David et al. (1997), comparando o método de dissipação de calor em cultura de eucalipto com o método de Pennan-Monteith (PM), quando as condições hídricas do solo eram ótimas, observaram uma tendência similar de variação. Entretanto, a medida que o solo vai secando, a evapotranspiração pelo método de PM passa a ser proporcionalmente superior ao fluxo de seiva.

Quando comparado o método de dissipação de calor com o de balanço de calor, em uma árvore tropical do Mediterrâneo (Gliricidia sepium) tanto em escala diária como horária, Tournebize \& Boistard (1998) observaram uma discrepância máxima de 10\%.

\subsection{Detecção da condição hídrica da planta}


Para caracterizar o grau do déficit hídrico, com a finalidade de otimizar o manejo da irrigação em culturas anuais, são utilizados indicadores do solo como o potencial matricial da água ou seu balanço hídrico, baseado na capacidade de armazenamento de água e na evapotranspiração diária estimada subseqüentemente (Angelocci, 2002). Mas, quando se trata de plantas isoladas, é muito difícil utilizar estes indicadores sem incorrer em grandes erros. Kramer \& Boyer (1995) afirmam que as próprias plantas são as melhores indicadoras do grau de disponibilidade hídrica por integrarem automaticamente os fatores que afetam o seu estado de hidratação e por isso, devem ser preferidos indicadores da própria planta. Na busca de tal indicador, têm sido utilizada uma grande quantidade de procedimentos de determinação de estresse hídrico, dentre os quais pode-se citar a variação da temperatura da folha, monitorada por sensores de radiação infravermelha (Jackson, 1982); potencial de água na folha com várias técnicas de medidas, como câmara de pressão, método higrométrico, etc. (Angelocci, 2002; Ameglio et al., 1997; Katerji et al., 1988); a detecção da cavitação dos vasos do xilema através de detetor de ultra-som (Hsiao, 1990); a variação da condutância estomática medida por porômetria (Angelocci, 2002), entre outros. Embora todos sejam indicadores originários da planta, sua aplicação prática apresenta dificuldades, seja pela variabilidade espacial e temporal dos indicadores como o potencial da água da folha e a condutância estomática à difusão de vapor, que também envolvem problemas na sua determinação por não permitirem a automação de medidas, seja pela dificuldade de se ter o significado adequado da medida como uma representação do déficit hídrico para todos esses indicadores. A dificuldade de se obter relações entre os indicadores citados e o grau de déficit hídrico é extensamente documentada na literatura (Jackson, 1982; Katerji et al., 1988; Hsiao, 1990; Ferreira, 1996a; Shackel et al., 1997).

Um parâmetro indicador do déficit hídrico que vem sendo testado há algum tempo é a medida de contração radial de caules ou de ramos ao longo de um dia, cuja amplitude é relacionada com a condição hídrica da planta (Huguet, 1985; Garnier \& Berger, 1986; Huguet \& Orlando, 1987; Ginestar \& Castel, 1998). 
A contração intermitente do diâmetro dos ramos ao longo de um determinado período, evidenciada em planta de citros por Hodgson ${ }^{3}$, Bartholomew ${ }^{4}$ e Halma ${ }^{5}$, citados por Huguet (1985), é induzido pelo desenvolvimento do gradiente de potencial da água entre o floema e o xilema, sendo ainda influenciados pela condutância hídrica entre ambos os tecidos (Dobbs \& Scott, 1971; Molz \& Klepper, 1973). Essa amplitude diária de contração de diâmetro depende da espécie, da demanda evaporativa do ar e da condição hídrica da planta (Garnier \& Berger, 1986; Ginestar \& Castel, 1998; Huguet, 1985; Huguet \& Orlando, 1987).

Foi visto que essa contração diária pode ser utilizada como indicador do estresse hídrico da planta mas, como a variação é muito pequena, foi necessário um aparelho muito sensível para registrar essas medidas. Hilgeman (1962) menciona que em 1960, o "dendrógrafo", descrito por Fritts \& Fritts ${ }^{6}$, foi utilizado para medir a contração diária do tronco de laranja Valência, no Arizona, Estados Unidos. Este aparelho, amplificava os valores micrométricos numa banda registradora sobre um tambor, de forma idêntica ao termógrafo ou higrógrafo.

O desenvolvimento de dendrômetros mais modernos, descrito por diversos autores (Dynamax, 1996; Higgs \& Jones, 1984; Huguet, 1985; Simonneau et al. 1993; So et al., 1979) tem facilitado as pesquisas sobre a utilização da contração radial de ramos como indicador de estresse hídrico das plantas.

Entre as pesquisas realizadas a respeito, têm-se relacionadas diversas variáveis com as medidas de variação de diâmetro de frutos (Higgs \& Jones, 1984; Huguet, 1985), de caules de plantas anuais como algodão (Parlange et al., 1975), milho (Katerji et al., 1994), soja (So et al., 1979), repolho (McBurney \& Costigan, 1984), berinjela (Katerji et al., 1990), pimentão (Cohen et al., 1998) e de ramos de plantas lenhosas como laranjeira (Hilgeman, 1962;

\footnotetext{
${ }^{3}$ HODGSON, R.W. Some abnormal water relation in citrus trees of the arid South-West an their possible significance. Univ. of California Publication Agricultural Science, v.3, p.37-55, 1917.

${ }^{4}$ BARTHOLOMEW, E.T. Internal decline of lemons. III. Water deficits in lemon fruit caused by exessive leaf evaporation. Annuary Journal of Botany, v.13, p102117, 1923.

${ }^{5}$ HALMA F.F. Some phasesin water relation in citrus. Proceeding American Society Horticultural Science, v.31, p.108-109, 1934.
} 
Ginestar \& Castel, 1998), pessegueiro (Garnier \& Berger, 1986; Goldhamer et al., 1999; Huguet et al., 1992; Li et al., 1990a, Li et al., 1990b; 1990b; Simonneau et al., 1993), e oliveira (Michelakis, 1997; Moriana et al., 2000).

Entre os parâmetros da medida de contração de diâmetro de ramos e caules, os mais utilizado são a Amplitude Diária de Contração (ADC), que é a diferença entre o máximo e mínimo valores observados em um da, e a variação do diâmetro máximo (DMax) que é diferença entre o máximo valor do diâmetro registrado no dia, menos o máximo valor do dia anterior, ou seja $\operatorname{DMax}=\operatorname{DMax}_{(\mathrm{i})}-\operatorname{DMax}_{(\mathrm{i}-1)}$. Goldhamer et al. (1999) utilizou outro parâmetro, a variação do diâmetro mínimo diário (DMin), afirmando que em pessegueiro este foi mais sensível do que ADC e DMax. O DMin é a diferença entre o mínimo valor do diâmetro registrado em um dia menos o mínimo valor do dia anterior; ou seja, $\mathrm{DMin}=\mathrm{DMin}_{(\mathrm{i})}$ - $\operatorname{DMin}_{(\mathrm{i}-1)}$.

Para tentar encontrar um indicador que possa ser utilizado para determinar a umidade crítica do solo, os pesquisadores relacionam os parâmetros da variação radial de ramos ou caule com alguma variável que condiciona o estado hídrico da planta. Com relação a esses parâmetros, alguns autores como Katerji et al. (1994), Ginestar \& Castel (1998) e Cohen et al. (1998), preferiram utilizar a DMax por responder mais coerentemente ao estresse hídrico que ADC. Garnier \& Berger (1986), assim como Ginestar \& Castel (1998), explicaram que esta preferência se deve ao fato de que ADC depende mais fortemente da demanda evaporativa do ar que da condição hídrica do solo. Katerji et al. (1994) mostraram graficamente que enquanto a $\mathrm{ADC}$ se mantinha constante, em uma condição de aumento gradativo de estresse hídrico, o DMax teve uma tendência negativa. Esta afirmação demonstra que o DMax pode ser mais adequado para indicar estresse hídrico. No entanto, Li et al. (1990a), em um experimento realizado em casa-de-vegetação, com pessegueiro, assim como Katerji et al. (1990) em berinjela, demostraram que DMax é inversamente proporcional à ADC, o que demonstra a existência de uma relação entre esses parâmetros. Por outro lado

\footnotetext{
${ }^{6}$ FRITTS, H.C.; FRITTS, E.C. A new dendograph for recording radial changes of a tree. Forest Science, v.1, p 271-276, 1955.
} 
Moriana et al. (2000), afirmaram ter boa resposta na utilização de ADC em oliveira quando correlacionado com o potencial da água no ramo. Estas controvérsias fazem entender que não pode ser tomada como absoluta a afirmação de certos autores quanto à aplicabilidade de um ou outro parâmetro.

A vantagem da técnica de detecção de variações micromorfométricas reside na sua sensibilidade quanto a detecção do balanço hídrico da planta. O ponto desfavorável é que a representatividade da medida como indicador do déficit não é universal, devendo ser determinada para a espécie em estudo a partir da sua relação com outros indicadores como potencial da água da folha, resistência foliar à difusão vapor d'água, potencial matricial do solo ou mesmo a transpiração da planta, se for possível sua medida. Somente após feito esse tipo de estudo, pode se estabelecer critérios sobre como a medida de variação de diâmetro pode ser usada como indicador do momento de se irrigar.

A transpiração relativa (TRR), expressa pela relação entre a transpiração atual de plantas lenhosas e a transpiração máxima, expressa por unidade de área foliar, tem sido usada como um indicador de estresse hídrico em lenhosas. A transpiração máxima é aquela que ocorre em condições ideais de disponibilidade hídrica no solo, dependendo portanto das condições de demanda atmosférica. Valancogne et al (1997), Ferreira (1997) e Massai et al (2000) utilizaram os métodos de balanço de calor e da sonda de dissipação térmica para a determinação do fluxo de seiva em varias frutíferas lenhosas, para determinar a variação da transpiração relativa durante a secagem do solo, demonstrando por associação com outros indicadores de estresse hídrico, como o potencial da água da folha no pré-amanhecer, a potencialidade de TRR em atuar como um indicador de estresse. 


\section{MATERIAL E MÉTODOS}

\subsection{Descrição da área experimental}

Os experimentos foram desenvolvidos na área experimental de irrigação da Fazenda Areão, do Departamento de Engenharia Rural, Escola Superior de Agricultura "Luiz de Queiroz”, Universidade de São Paulo (USP), situada no município de Piracicaba, SP, nas

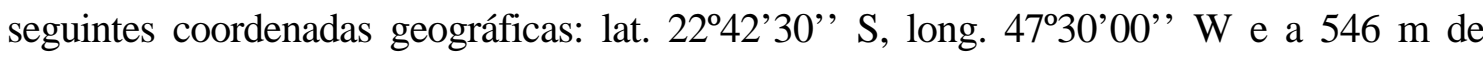
altitude.

Os experimentos foram instalados em dois pomares de lima ácida "Tahiti", o primeiro envolvendo plantas adultas que atualmente se encontram com nove anos de idade e o segundo com plantas jovens que foram transplantados em junho de 2001. As plantas adultas estão enxertadas sobre limão 'Cravo' (híbrido de Citrus aurantifolia e Citrus reticulata) (Simão, 1998), irrigado por microaspersão (1 microaspersor por planta) . A plantas jovens estão enxertadas sobre citrumelo (Citromelo swingo S.), com copas do clone IAC 5, sendo o pomar de 1 ha, irrigado por gotejadores (4 gotejadores por planta). O espaçamento das plantas nos pomares é de $8 \mathrm{~m}$ x $7 \mathrm{~m} \mathrm{e} 4 \mathrm{~m}$ x $7 \mathrm{~m}$, respectivamente.

O solo da área do experimento é classificado como Terra Roxa Estruturada Eutrófica, "A" moderado com textura franco argilosa. O declive de ambos os pomares são suaves ondulados e com uma erosão laminar moderada.

Foram utilizadas dois lisímetros de pesagem por células de carga para testar as medidas de transpiração estimada a partir do fluxo de seiva pelo método de dissipação de calor. Eles estão instalados no pomar jovem (ver Fig. 4) e a dimensão dos mesmos são de 0,8 $\mathrm{m}$ de diâmetro por $0,8 \mathrm{~m}$ de profundidade e $1,8 \mathrm{~m}$ de diâmetro por $1 \mathrm{~m}$ de profundidade, respectivamente (Campeche, 2001).

Os elementos climáticos como a temperatura do ar, umidade relativa, precipitação, velocidade do vento, radiação global, radiação líquida e evaporação do Tanque "Classe A", 
foram registrados em uma estação meteorológica automatizada, localizada entre os pomares, com aproximadamente $100 \mathrm{~m}$ de eqüidistância de ambos. Todos os dados medidos durante a experimentação, exceto a tensiometria e os parâmetros de crescimento da planta, foram armazenados automaticamente através de um sistema de aquisição de dados ou "datalogger" da marca Campbell Scientific, modelos CR7, CR10 e/ou 21X, com leitura a cada segundo e médias a cada 15 ou 20 minutos, conforme a época em que foram realizadas as medidas.

\subsection{Determinação do fluxo de seiva}

\subsubsection{Método de balanço de calor}

\subsubsection{Princípios do método}

O princípio teórico deste método de medida consiste na aplicação de um pequeno fluxo constante de calor (W) a um segmento de tronco ou ramo, através de uma jaqueta térmica que o envolve. São quantificadas a partição desse calor nos fluxos conductivos axiais $(\mathrm{Qc}$ e $\mathrm{Qb})$, radiais $(\mathrm{Ql})$ e na variação de armazenamento $(\mathrm{Q} a)$ no volume correspondente ao segmento aquecido. O calor dissipado convectivamente pela seiva (Qs) é calculado, pelo princípio de conservação da energia, como termo residual do balanço de calor, sendo Qs associado ao fluxo volumétrico da seiva. Na figura 1 pode ser observado esquematicamente $\mathrm{o}$ conjunto de medidas térmicas que envolvem este método. Todos os componentes são expressos em watts. 


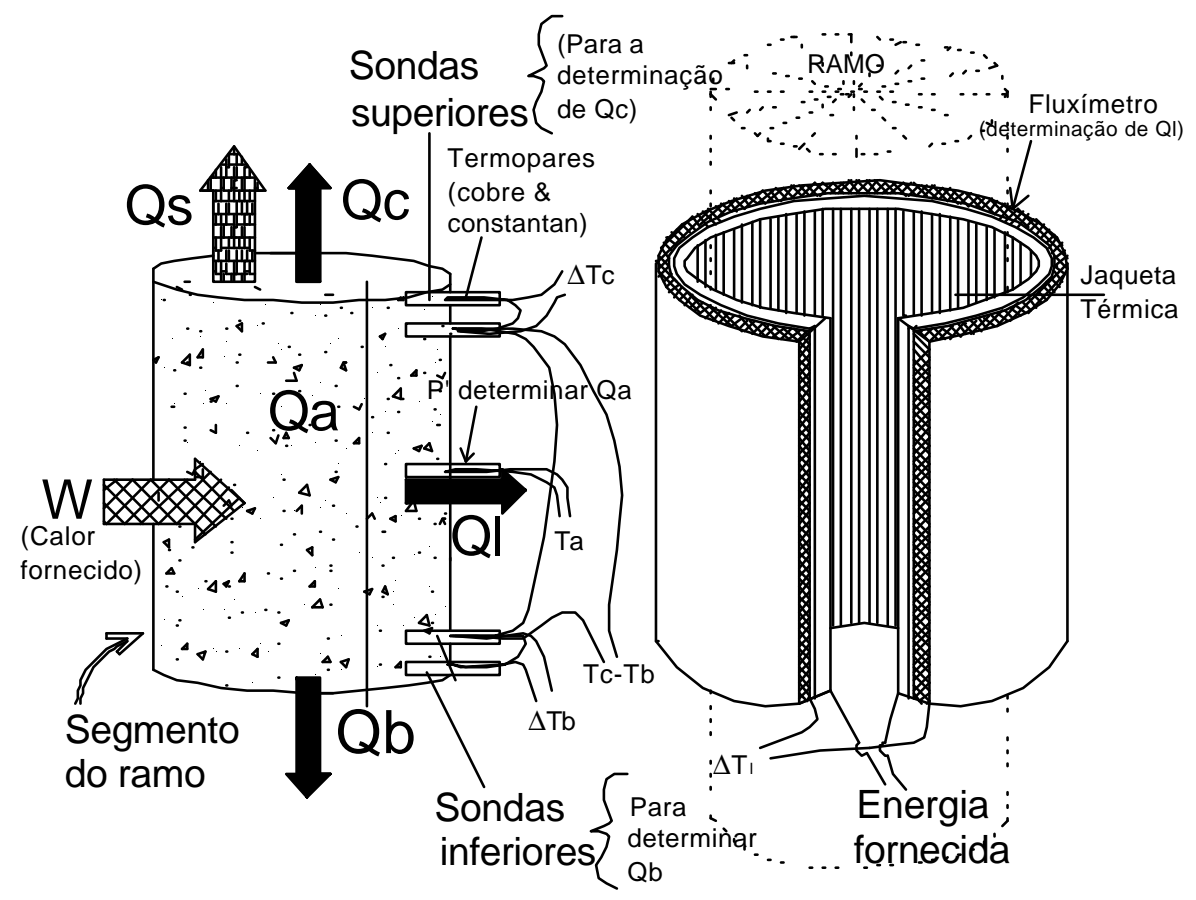

Figura 1 - Esquema do princípio do método de balanço de calor e do sensor para determinação de fluxo de seiva.

A equação geral do balanço de calor é descrita como:

$$
\mathrm{W}=\mathrm{Qb}+\mathrm{Qc}+\mathrm{Q} \mathrm{l}+\mathrm{Qs}+\mathrm{Qa}
$$

A potência (W) que deve ser fornecida depende do diâmetro do ramo (D) e pode ser calculada em primeira aproximação, conforme Dayau (s/d), através da seguinte expressão:

$$
\mathrm{W}=2,1 \cdot \mathrm{D}^{2} / 81
$$

A partir deste valor, a resistência total da jaqueta térmica $(\mathrm{R})$ é previamente calculada através da seguinte fórmula:

$$
\mathrm{R}=\mathrm{V}^{2} / \mathrm{W}
$$

sendo $\mathrm{V}$ a diferença de potencial elétrico que deve ser aplicado. 
Qs pode ser associado ao fluxo de seiva (F) pela expressão:

$$
\mathrm{Qs}=\mathrm{c}_{\mathrm{vs}} \cdot \mathrm{F} \cdot\left(\mathrm{T}_{\mathrm{c}}-\mathrm{T}_{\mathrm{b}}\right)
$$

(9)

em que $c_{v s}$ é a capacidade calorífica volumétrica da seiva bruta $\left(4,18.10^{6} \mathrm{~J} / \mathrm{m}^{3} .{ }^{\circ} \mathrm{C}\right)$, considerada igual a da água pura; Tb e Tc são as temperaturas médias das seções transversais nos limites inferior e superior do volume amostrado.

Substituindo a eq. 9 na eq. 6, o fluxo de seiva (F) pode ser isolado da seguinte maneira:

$$
F=\frac{W-[(Q c-Q b)-Q l-Q a]}{\left.c_{v s}(T c-T b)\right)}
$$

Qb e Qc, são estimados aplicando a lei de transporte de calor de Fourier (Valancogne \& Granier, 1994), através das seguintes equações:

$$
\begin{aligned}
& \mathrm{Qb}=-\alpha \cdot \mathrm{A}_{\mathrm{b} \cdot}(\mathrm{dT} / \mathrm{dx})_{\mathrm{b}} \\
& Q \mathrm{Qc}=-\alpha \cdot \mathrm{A}_{\mathrm{c} \cdot}(\mathrm{dT} / \mathrm{dx})_{\mathrm{c}}
\end{aligned}
$$

em que $\alpha$ é a condutividade térmica do tronco $\left(0,4\right.$ a $\left.0,6 \mathrm{~W} / \mathrm{m} .{ }^{\circ} \mathrm{C}\right), \mathrm{A}_{\mathrm{c}}$ e $\mathrm{A}_{\mathrm{b}}$ são as superfícies das secções transversais dos extremos superior e inferior do cilindro considerado; $(\mathrm{dT} / \mathrm{dx})_{\mathrm{b}} \mathrm{e}$ $(\mathrm{dT} / \mathrm{dx})_{\mathrm{c}}$ são os respectivos gradientes térmicos nesses limites. O termo dx representa a distância entre as sondas colocadas nas extremidades $(1 \mathrm{~cm}$, neste caso).

A variação do armazenamento de calor no segmento é determinado por:

$$
Q a=c_{v m} \cdot V \cdot \frac{\Delta \bar{T}}{\Delta t}
$$

em que $c_{\mathrm{vm}}$ é o calor específico volumétrico da madeira úmida, assumido como um valor fixo de $2,8 \mathrm{~J} / \mathrm{m}^{3} .{ }^{\circ} \mathrm{C}$, (Angelocci, 1995); V é o volume do segmento considerado $\left(\mathrm{m}^{3}\right)$ e $\Delta \mathrm{T} / \Delta \mathrm{t}$ é a 
variação da temperatura média do segmento $\Delta \mathrm{T}$ (medido com Ta, conforme a Fig. 2), no intervalo de tempo $(\Delta \mathrm{t})$ considerado.

O fluxo lateral Q1 é determinado por um fluxímetro de termopilha, pela medida da força eletromotriz gerada através da lamina do material de construção do fluxímetro, que depende da temperatura entre os lados da lâmina e da condutância térmica dessa lâmina, pela equação:

$$
\mathrm{Ql}=-\mathrm{Kf} . \Delta \mathrm{Tl}
$$

Devido à dificuldade em medir $\mathrm{Kf}\left(\mathrm{em} \mathrm{W} /{ }^{\circ} \mathrm{C}\right)$, utilizou-se um método alternativo sugerido por Valancogne \& Nasr (1989) que consiste no seguinte: admitindo o fluxo de seiva nulo no final da madrugada, antes do nascer o sol, pode ser medido o coeficiente de condução de calor do fluxímetro (Klat, em $\mathrm{W} /{ }^{\circ} \mathrm{C}$ ), considerando que ele seja uma constante quando o transporte convectivo é nulo. É expresso pela seguinte equação:

$$
\mathrm{Klat}=[\mathrm{W}-(\mathrm{Qc}-\mathrm{Qb})-\mathrm{Qa}] / \Delta \mathrm{Tl}
$$

O valor de W é conhecido, Qb, Qc e Qa podem ser determinados facilmente pelas equações 11,12 e 13 respectivamente e $\Delta$ Tl é medido através do fluxímetro.

Como todas as medidas têm explicações físicas e se forem mensuradas levando em consideração todas a recomendações, este método não precisa de calibração.

A confecção e a montagem dos sensores foram realizadas no Departamento de Ciências Exatas da ESALQ/USP, sob consulta de trabalhos elaborados por Angelocci (1995), Dayau (s/d), Steinberg et al. (1989) e Valancogne \& Granier (1994). A altura de cada sensor foi equivalente a $1,5 \mathrm{vez}$ o diâmetro do ramo onde foi instalado.

O sensor foi constituído por uma jaqueta dissipadora de calor, construída pela imersão de fio de constantan de $1 \mathrm{~mm}$ de diâmetro, em mistura de silicone líquido com catalisador específico (proporção em peso de 10:1). Esse procedimento de construção foi feito, utilizando-se um molde constituído por uma placa de madeira nas dimensões do sensor, 
forrada com placa de fórmica. Peças laterais com 5 a $10 \mathrm{~mm}$ de altura, de madeira ou ferro, formaram uma parede baixa que serviu para reter o silicone líquido a ser usado na posição e formar o conjunto sensor na forma retangular. Na base (placa de madeira) do molde foi colocado o fluxímetro para medida do fluxo lateral de calor, constituído por três linhas eqüidistantes de 8 termopares em cada linha, em cada lado de uma placa de silicone homogênea ( $1 \mathrm{~mm}$ de espessura). Sobre o fluxímetro assentado no molde foi instalado o fio de constantan na forma de sanfona e o silicone liquido, já misturado com o catalisador, foi distribuído sobre esse fio e deixado a secar por um dia. Após a secagem, tem-se o sensor formado em um monobloco, constituído da jaqueta dissipadora (fio de constantan fixado na placa de silicone) aderida ao fluxímetro.

Para medir a diferença de temperatura nas extremidades do segmento $(\Delta \mathrm{Tb}$ e $\Delta \mathrm{Tc}$, Figura 1) e calcular os gradientes $(\mathrm{dT} / \mathrm{dx})_{\mathrm{c}}$ e $(\mathrm{dT} / \mathrm{dx})_{\mathrm{b}}$, das eqs. 11 e 12 , foram confeccionados termopares de cobre-constantan com fios de diâmetro de $50 u$ m e introduzidos em tubos de latão com diâmetro interno de $2 \mathrm{~mm}$, sendo as sondas assim formadas, introduzidas nas extremidades do segmento do tronco até uma profundidade equivalente a 1/4 do seu raio (ver esquema na Fig. 2). O espaçamento vertical entre as sondas em cada limite do segmento amostrado foi de $1 \mathrm{~cm}$. Uma sonda similar foi confeccionada e introduzida na parte central do segmento, para medir a temperatura interna (Ta) e determinar Qa (equação 13).

A instalação do sensor no ramo foi realizada da seguinte maneira: após ter sido limpo o segmento do tronco a ser amostrado e introduzidas as sondas de temperatura, instalou-se o conjunto jaqueta térmica - fluxímetro. Foi superposta uma lâmina de polietileno com bolhas de ar que, ao ser fixada sob tensão, ajudou a melhorar o contato entre o sensor e a superfície do ramo, colaborando ainda para o isolamento térmico. Todo o conjunto foi envolto por duas voltas de placa de neopreno, de espessura de $1 \mathrm{~cm}$, para aumentar o isolamento térmico e minimizar o efeito da carga radiante. Novamente foi superposta outra lâmina de polietileno de bolha, vedando todo o conjunto com fitas adesivas para evitar a entrada de insetos e água de chuva. Finalmente, fez-se uma cobertura com papel aluminizado para refletir a energia radiante no tronco e minimizar ainda mais a carga térmica sobre o sensor. 


\subsubsection{Avaliação do desempenho do método de balanço de calor em plantas adultas}

O experimento foi instalado durante o mês de agosto de 2001 no pomar de plantas adultas, com uso de duas plantas. As medidas foram realizadas entre o dia 31 de Agosto e 13 de Setembro.

A umidade do solo foi monitorada diariamente através de uma bateria de tensiômetros, instalados à profundidade de 10, 20, 30, 40, 50, 60, 70, 80 e 100 cm, com seis repetições cada um, à distância de 1 a 2 metros do tronco. As leituras foram feitas com um tensímetro digital.

A irregularidade dos troncos exigiu que os sensores de balanço de calor fossem instalados em 4 ramos principais em duas árvores, sendo colocado um sensor em cada ramo. Os diâmetros dos ramos principais da planta 1 (P1), na altura de instalação do sensor, eram de $9 ; 15,5 ; 9,5$ e 8 cm enquanto que os da planta 2 (P2) eram de $12 ; 11,3 ; 12,4$ e 9,3 cm.

A análise de dados consistiu na observação do comportamento de cada uma das medidas térmicas que envolveram todo o conjunto de variáveis necessárias para realizar o cálculo de fluxo de seiva. Isto foi importante para compreender e dominar a técnica, de tal forma que se uma dessas medidas tiver uma tendência diferente da esperada, pode ser identificada imediatamente e tentada uma solucionar do problema o mais rápido possível. A segunda parte consistiu no cálculo e comparação da transpiração entre cada ramo e entre as plantas envolvidas no experimento. Avaliou-se a coerência das medidas, considerando o tamanho de cada ramo e o comportamento da transpiração total da planta com relação à evolução da ETo. 
Apesar da técnica de balanço de calor já ter sido testada localmente em plantas jovens de citros por Trejo-Chandia (1997) e Coelho Filho (2002), tendo apresentado bom desempenho, nova análise do seu desempenho foi feita pois, por se tratar de técnica complexa, é recomendável que as medidas de cada fluxo sejam analisadas no seu uso na pequisa. Além disso, não se conhece teste do seu desempenho em comparação com outra técnica em plantas cítricas adultas, o que foi tentado neste trabalho, conforme discussão apresentada no item 3.2.2.2 em comparação com o método de sonda de dissipação de calor.

\subsubsection{Método de sonda de dissipação de calor}

\subsubsection{Princípios do método}

Como foi visto no item 2.3.2, o método de dissipação de calor consiste na relação entre a densidade de transporte convectivo de massa (seiva) através da seção transversal do tronco ou ramo e a velocidade de dissipação de calor ocasionado pelo citado transporte. Em condição hídrica normal da planta, esta variação acompanha normalmente a demanda atmosférica do meio ambiente em função da radiação solar, temperatura, vento, umidade do ar, etc. No período noturno existe ainda um pequeno fluxo de seiva bruta através do tronco, para suprir a deficiência hídrica na parte aérea da planta que ocorre devido à transpiração durante o período diurno; este fluxo tende a se tornar mínimo ou nulo ao final da noite, sob condições de boa disponibilidade hídrica no solo (Angelocci, 2002).

O sistema de medida envolve a inserção perpendicular no tronco de duas sondas distanciadas entre si de 8 a $10 \mathrm{~cm}$, na mesma linha vertical do tronco. A sonda superior é aquecida de forma constante com fornecimento de potência elétrica de 0,2 watt. A variação da diferença de temperatura entre a sonda aquecida e a não aquecida em cada instante é determinada pelo transporte convectivo de calor através da seiva; portanto, a máxima diferença entre as duas sondas em um período significa que o fluxo de seiva é mínimo ou nulo, enquanto que a mínima diferença significa uma taxa máxima de fluxo de seiva através dessa 
área de transporte (Granier, 1987). Na Figura 2 observa-se as duas sondas que compõem o sensor de Granier, ou sonda de dissipação de calor.



Detalhes da sonda de dissipação de calor

Figura 2 - Esquema do sensor de Granier inserida perpendicularmente no tronco de uma árvore. Observa-se a conexão dos termopares ao sistema de aquisição de dados e da sonda superior a uma fonte de energia.

$\varepsilon$

A sonda dissipadora de calor foi confeccionada com fio de constantan de diâmetro de 0,5 mm enrolado em volta de uma agulha de aço inoxidável, com diâmetro de $2 \mathrm{~mm}$ e comprimento de $16 \mathrm{~mm}$ para plantas jovens e de $24 \mathrm{~mm}$ para plantas adultas. Para inserir cada sonda no tronco, previamente foi introduzida uma cápsula de alumínio em cujo interior foi introduzida pasta térmica para uniformizar o calor em volta da sonda que se encontra dentro dessa cápsula. Após a instalação dos sensores foram colocadas folhas de papel aluminizado cobrindo a maior parte do ramo ou tronco para evitar o efeito da incidência da radiação eletromagnética sobre as medidas. 
A medida da variação de temperatura entre as duas sondas foi feita pelo uso de um termopar de cobre-constantan de diâmetro de $50 \mu \mathrm{m}$, sendo cada junção de termopar inserida em cada agulha, fornecendo diretamente a diferença de temperatura, registrada em "datalogger" marca Campbell, modelo CR10x.

Na determinação do fluxo de seiva, Granier (1985) propôs uma relação entre a demanda de fluxo de seiva 'u' (em $\mathrm{m} \mathrm{s}^{-1}$ ) e um fator $\mathrm{k}$ característico de cada espécie vegetal. Para espécies lenhosas, aquele autor encontrou a seguinte relação:

$$
\mathrm{k}=(\Delta \mathrm{TM}-\Delta \mathrm{T}) / \Delta \mathrm{T}=0,0206 \mathrm{u}^{0,8124}
$$

sendo $\Delta \mathrm{TM}\left({ }^{\circ} \mathrm{C}\right)$ a diferença máxima de temperatura entre os dois pontos de medida, que normalmente acontece durante a madrugada e $\Delta \mathrm{T}\left({ }^{\circ} \mathrm{C}\right)$ a diferença de temperatura atual.

Essa relação é transformada na equação 18, para se Ter o fluxo de seiva $\mathrm{F}$ em qualquer espécie lenhosa, conforme recomendação do introdutor do método:

$$
\mathrm{F}=118,99 \cdot 10^{-6} \cdot \mathrm{k}^{1,231} \cdot \mathrm{AS}
$$

sendo AS é a área do lenho condutor da seiva bruta, dada $\mathrm{em}^{2}$, normalmente considerada a área ocupada pelo xilema e k calcula-se através da equação 17 a partir das medidas térmicas registradas.

É importante ressaltar que num período longo de tempo o valor da $\Delta \mathrm{TM}$ pode variar devido, talvez, à alteração das propriedades térmicas do xilema (Tavares, 1993); portanto, deve ser revisto este valor se possível para cada dia, calculando-se em base ao comportamento dessa tendência, a partir da sua observação gráfica.

Para determinar a área efetiva do xilema foi forçada a passagem de água com corante vermelho (anilina) através de um segmento de ramo de $25 \mathrm{~cm}$ de comprimento e $10 \mathrm{~cm}$ de diâmetro. Verificou-se que toda a área do corte transversal do ramo podia ser considerada área efetiva de xilema, excluindo apenas cerca de $4 \mathrm{~mm}$ do contorno, ocupado pela casca. Este critério foi adotado nas outras plantas. 


\subsubsection{Avaliação do método da sonda de dissipação de calor}

O método foi avaliado de duas formas, a partir do mês de agosto de 2002, na primeira, no pomar de plantas adultas, envolvendo 4 plantas e na segunda, no pomar de plantas jovens, envolvendo 2 plantas. Nas plantas adultas, devido as ramificações irregulares na base do tronco, preferiu-se instalar um sensor em cada ramo primário. A quantidade de ramos por plantas foi de 5, 3, 4 e 4 respectivamente, perfazendo um total de 16 sensores. Embora todo o pomar fosse irrigado com microaspersores, visando ter controle individual, as quatro plantas envolvidas na avaliação foram irrigadas através de um sistema de irrigação independente, utilizando gotejadores com uma vazão de $36 \mathrm{~L} \mathrm{hora}^{-1}$ planta $^{-1}$.

A determinação da área foliar foi feita pela estimativa da área média das folhas (AM), usando-se a seguinte relação determinada previamente:

$$
\mathrm{AM}=\mathrm{C} \times \mathrm{L} \times \mathrm{k}
$$

onde, C é o comprimento e L é a máxima largura das folhas e k $(0,71)$ é um fator de correção da fórmula, obtido previamente pela delimitação de seu contorno sobre papel milimetrado. Essa área média foi estimada pela medida de C e L em 100 delas tomadas aleatoriamente. Para obter a área foliar total do ramo, essa área média foi multiplicada pelo número total de folhas contado no ramo.

Na primeira avaliação foi analisado o funcionamento do sensor de dissipação de calor quanto ao comportamento dos valores térmicos medidos no tronco, sob diferentes condições hídricas da planta, assim como a sua sensibilidade com relação às mudanças energéticas do ambiente. Alem disso, pela dificuldade de se ter um método de referência para se medir a transpiração de árvores de grande porte, com as do pomar adulto, os valores de fluxo de seiva estimados pela sonda de dissipação de calor foram comparados com os valores pelo método de balanço de calor. Para tal, foram feitas medidas simultâneas de fluxo de seiva 
através de ambos os métodos num mesmo ramo, com diâmetro de 10,5 cm (Figura 3.b). Nas plantas jovens, a avaliação foi feita relacionando os valores diários obtidos com a sonda de dissipação de calor com a transpiração medidas através de dois lisímetros de pesagem. Nesta

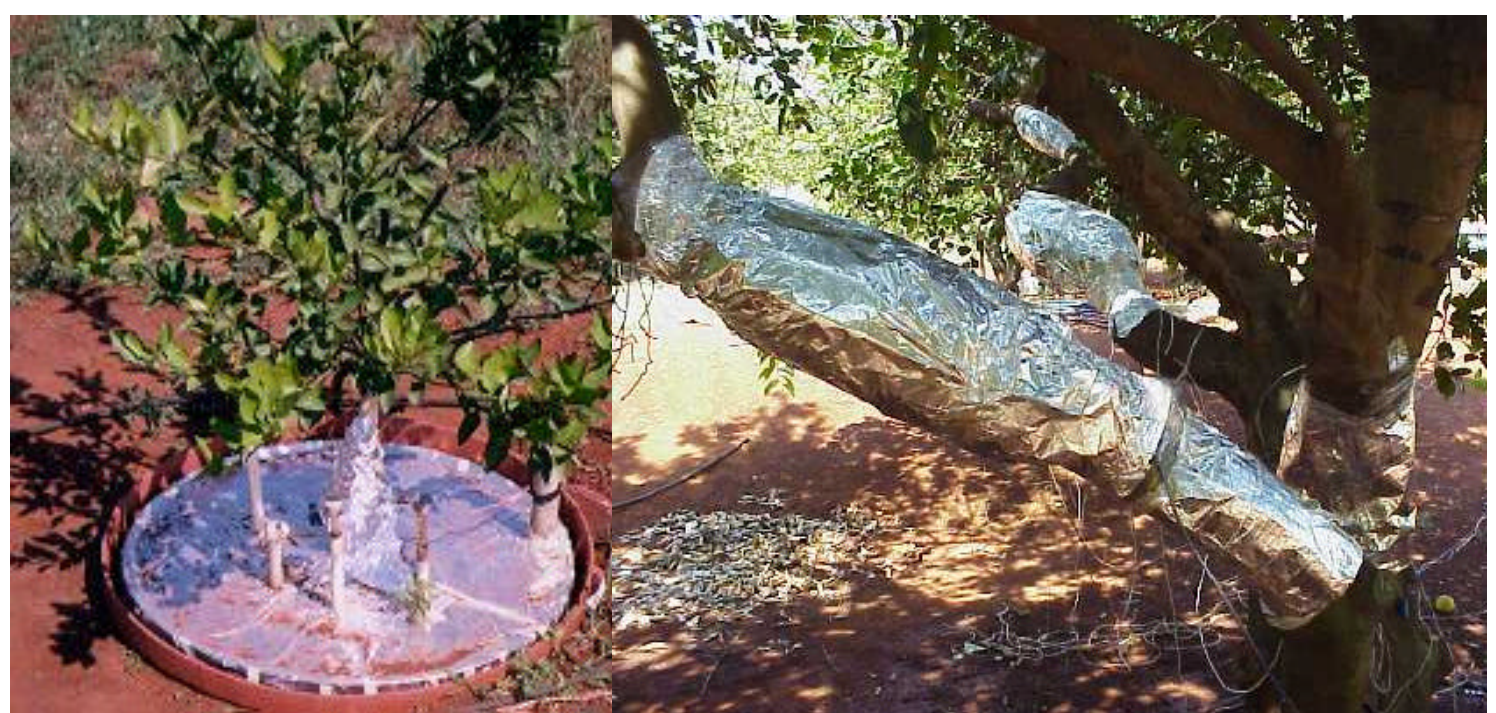

avaliação foram envolvidas duas plantas, sendo a superfície do solo dos lisímetros coberta com plástico, de maneira a somente ocorrer a transpiração (Figura 3.a).

Figura 3 - (a) Lima ácida "Tahiti" jovem plantada num lisímetro de pesagem coberto com plástico para medir apenas a transpiração da planta. Também é observado o sensor fluxo de seiva por dissipação de calor colocado na base do tronco e os tensiômetros para controle de irrigação. (b) Ramo de uma planta adulta de lima "Tahití" onde foram colocados dois tipos de sensores de fluxo de seiva, o de balanço de calor (MBC) e o de sonda de dissipação térmica (SDT).

O interesse em dominar a técnica d $\mathrm{MBC}$ de fluxo de seiva através da sonda de dissipação, desde a confecção do sensor até a sua 1nstalação e avaliação dos valores térmicos envolvidos no sistema, tanto em plantas jovens como em adultas, foi p/p subsidiar sua $\mathbf{a}$ ação na determinação da transp $\mathbf{b}$, por suas vantagens em SDT ıo método de
balanço de calor, principalmente quanto à simplicidade de construção, menor custo, necessidade de menor número de canais no sistema de aquisição de dados, além da possibilidade de uso do sensor por um tempo mais prolongado no caule ou ramo. A avaliação 
do método é necessária, pois não se encontrou na literatura referência ao seu uso em espécies cítricas.

O monitoramento do potencial mátrico da água do solo foi feito por tensiometria, sendo o esquema de medidas usado no pomar adulto discutido no item 3.2.1.2. No pomar jovem, foram instalados tensiometros em torno de cada planta nas profundidades de 0,10 ; 0,20; 0,30 e 0,50 m. A leitura dos tensiômetros foi realizada pelo uso de tensímetro digital de punção.

\subsection{Determinação das variações micrométricas do diâmetro de ramos e caules por dendrometria de precisão}

\subsubsection{Descrição e características técnicas do dendrômetro}

Os dendrômetros de precisão ou LVDT utilizados no experimento são da marca Dynamax, modelos DEX70 e DEX100. Como elemento sensível, o aparelho conta com um potenciômetro tipo "straingage", também conhecido como extensômetro de resistência indutiva tipo Carlson, fixado sobre um braço metálico flexível.

O princípio de medição do LVDT é baseado na transferência magnética, o que se traduz numa resolução infinita: a menor fração de movimento do braço pode ser detectada por um condicionador de sinais adequado. A combinação destes dois fatores em conjunto com outros (como a precisão e repetitividade) asseguram o sucesso deste tipo de transdutor.

O LVDT é um dispositivo eletromecânico que produz um sinal elétrico de saída proporcional ao deslocamento da sua parte móvel (núcleo magnético) composto por três enrolamentos cilíndricos, um primário (excitado normalmente por uma corrente contínua) e dois secundários, espaçados de forma simétrica relativamente ao primário e ligados entre si em série e em oposição. O núcleo magnético cilíndrico no interior dos enrolamentos encaminha o fluxo magnético através destes. Quando o núcleo encontra-se na posição central (posição 
zero) relativamente aos enrolamentos secundários, as amplitudes das tensões induzidas em cada um dos enrolamentos secundários são iguais, sendo contudo as respectivas polaridades de sinais opostos, resultando assim num sinal de saída nulo. Assim, a magnitude de saída aumenta de forma independente da direção do movimento, a partir da posição zero estabelecida no início, podendo ter valor negativo ou positivo. No caso do dendrômetro utilizado, durante sua instalação é estabelecido um valor qualquer, normalmente $6 \mathrm{~mm}$ (positivo), a partir do qual é realizada a medição.

Entre as características do dendrômetro utilizado (fig. 4), conforme Dynamax (1996), destaca-se a necessidade de um sistema de fornecimento de tensão elétrica, fornecida pelo datalogger, igual ou menor que 7,5 volts, utilizando uma indução mínima de 0,5 volt para registrar valores com uma resolução de 7 micrômetros $(0,007$ mm).

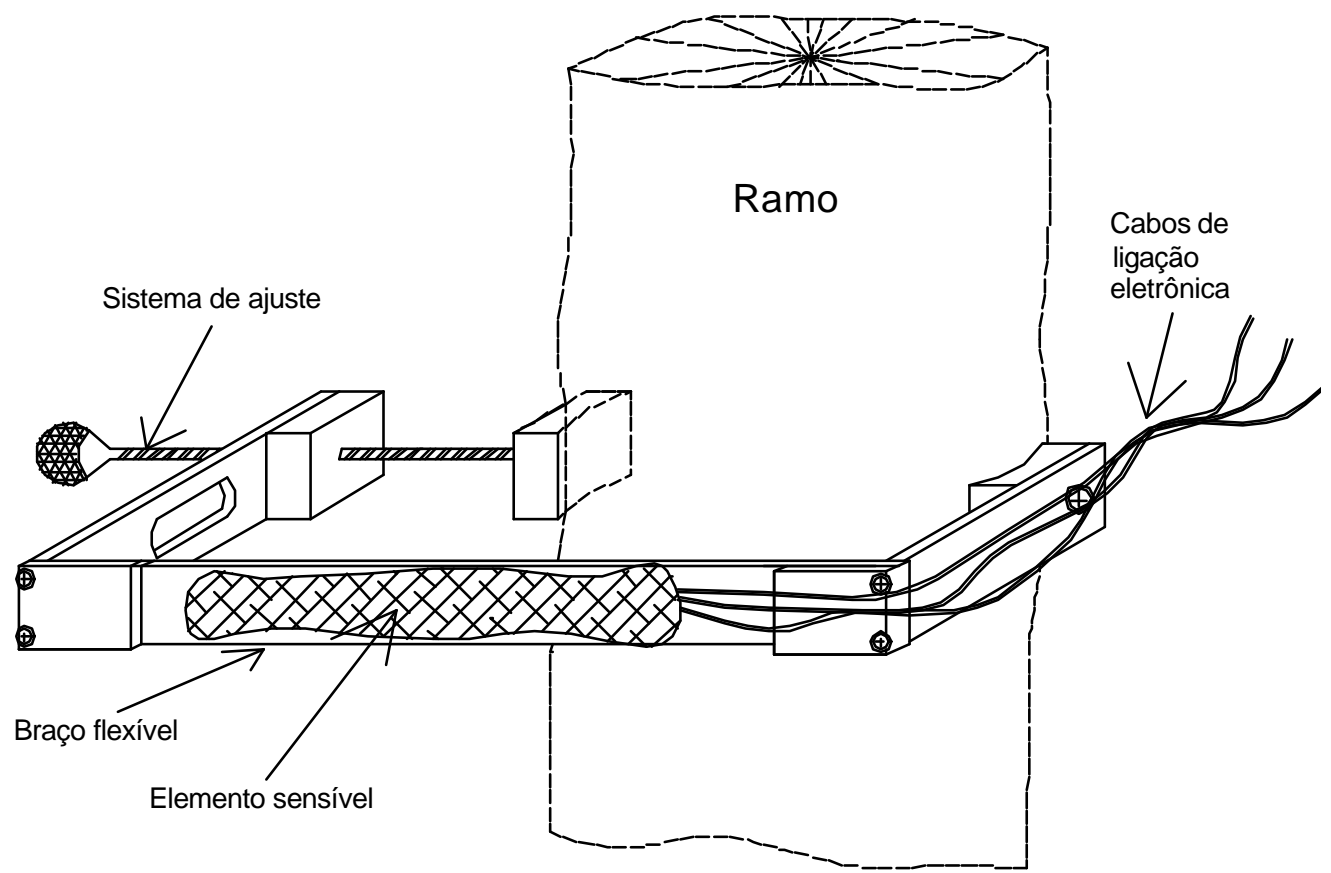

Figura 4 - Esquema detalhado de um dendrômetro da marca Dynamax instalado em um ramo.

A tensão de saída (em milivolt), registrada pelo "datalogger", é convertida em milímetros através de um fator encontrado durante a sua calibragem; assim, cada aparelho tem um fator de calibragem diferente. Ele é calibrado para trabalhar com uma amplitude de leitura menor que $13 \mathrm{~mm}$. Para maior versatilidade, o modelo DEX100 conta com um sistema de 
ajuste de até $100 \mathrm{~mm}$ de diâmetro do caule, enquanto que o DEX70 possui capacidade de ajuste de até $70 \mathrm{~mm}$ de diâmetro (Fig. 4).

\subsubsection{Avaliação do desempenho do dendrômetro de precisão e das variações micrométricas}

No período compreendido entre o dia 21 de março e 15 de maio de 2000 foram instalados dois dendrômetros de precisão, em dois ramos de 3,5 e 6,4 cm de diâmetro, em uma planta adulta. O objetivo dessa instalação foi testar os aparelhos observando principalmente a sensibilidade e a precisão de suas medidas. A tendência das contrações diárias dos ramos foi relacionada com as condições hídricas e microclimáticas em que se encontrava a planta.

Os parâmetros dendrométricos utilizados na avaliação foram a amplitude diária de contração (ADC) e a variação do diâmetro máximo (DMax). Como visto no Item 2.4, ADC $=\operatorname{DMax}_{\mathrm{i}}-\mathrm{DMin}_{\mathrm{i}}$ enquanto que DMax $=\operatorname{DMax}_{(\mathrm{i})}-\operatorname{DMax}_{(\mathrm{i}-1)}$. Também foi utilizado outro parâmetro denominado evolução diária do diâmetro (ED) que é o comportamento do diâmetro médio do ramo em dias subsequentes, a partir de um valor fixado arbitrariamente.

As análises consistiram na observação da sensibilidade e comportamento desses parâmetros dendrométricos com relação ao balanço hídrico do solo $(\mathrm{BH})$, precipitação, evapotranspiração real ETr e de referência ETo. Estes dois últimos parâmetros foram calculados a partir do balanço hídrico seqüencial diário, obtido pelo método de Thornthwaite \& Mather (1955), equacionado por Mendonça (1958).

Conforme Machado (2000), a quase totalidade do sistema radicular do porta-enxerto "limão cravo" se encontra na camada de $50 \mathrm{~cm}$, e no cálculo do $\mathrm{BH}$ foi assumido uma capacidade de água disponível (CAD) de $80 \mathrm{~mm}$, com uma capacidade de retenção de 1,6 mm de água/cm de solo. O método de evapotranspiração de referência (ETo) utilizado no balanço foi o de Penman-Monteith, parametrizado por Smith (1991):

$$
E T o=\frac{s}{s+\gamma^{*}}(R n-G) \frac{1}{\lambda}+\frac{\gamma}{s+\gamma^{*}} \cdot \frac{900}{(T+275)} \cdot U_{2} \cdot\left(e_{s}-e_{a}\right) \quad(\mathrm{mm} / \mathrm{d})
$$


onde s é a declividade da curva de pressão de vapor, dada pela seguinte fórmula:

$$
s=\frac{4098 \cdot e_{s}}{(T+237,3)^{2}} \quad\left(\mathrm{kPa} /{ }^{\circ} \mathrm{C}\right)
$$

onde e é a pressão de vapor de saturação, que pode ser calculada através da equação de Tetens:

$$
e s=0,6108.10^{\left(\frac{7,5^{*} T}{237,3+T}\right)} \quad(\mathrm{kPa})
$$

sendo $\mathrm{T}$ a temperatura média do ar; $\gamma^{*}$ é a constante psicrométrica modificada, calculada através da fórmula:

$$
\gamma^{*}=\gamma \cdot\left(1+0,33 \cdot U_{2 m}\right) \quad\left(\mathrm{kPa} /{ }^{\circ} \mathrm{C}\right)
$$

sendo $\gamma$ o coeficiente psicrométrico $\left(0,0622 \mathrm{kPa}{ }^{\circ} \mathrm{C}^{-1}\right)$ e $\mathrm{U}_{2}$ a velocidade do vento $(\mathrm{m} / \mathrm{s}) \mathrm{a}$ dois metros de altura. $\lambda$ é o calor latente de evaporação $\left(2,46 \mathrm{MJ} \mathrm{kg}^{-1}\right)$ e $\mathrm{Rn}$ é a radiação líquida $\left(\mathrm{MJ} \mathrm{m}^{-2} \mathrm{~d}^{-1}\right)$ medida na estação agro-meteorológica. $\mathrm{O}$ fluxo diário de calor no solo

$\left(\mathrm{G}, \mathrm{MJ} \mathrm{m}^{-2} \mathrm{~d}^{-1}\right)$ foi considerado desprezível, admitindo que não teria influência considerável no resultado e a pressão parcial de vapor $\left(\mathrm{e}_{\mathrm{a}}\right)$ foi calculada a partir da umidade relativa (UR) medida no local dos pomares por sensor capacitivo "Vaisalla", através da seguinte fórmula:

$$
e_{a}=e s . U R / 100 \quad(\mathrm{kPa})
$$

Este método de determinação da ETo engloba o maior conjunto de elementos que caracteriza o ambiente enquanto à energia disponível e ao poder evaporante do ar. O conjunto desses elementos que compõem a equação, juntamente com a condição hídrica do solo, atuam diretamente sobre a transpiração da planta e, portanto, sobre a variação radial do ramo.

\subsection{Avaliação das condições hídricas das plantas}

Entre os anos de 2000 e 2002, foram realizadas campanhas de medidas com a finalidade de se avaliar as condições hídricas das plantas através das medidas de fluxo de seiva e dendrométricas. Como se trata de um trabalho de campo sob condições naturais, as medidas foram realizadas no período de estiagem, começando em março de 2000 com testes dos dendrômetros e prolongando-se até maio daquele ano. As campanhas restantes 
ocorreram predominantemente no segundo semestre, entre agosto e novembro, época de retomada de crescimento, normalmente com ocorrência de grande deficiência hídrica no solo e elevada demanda evaporativa da atmosfera, principalmente nos meses iniciais desse período.

\subsection{Relação entre a variação radial do caule e o déficit hídrico em plantas jovens}

Este experimento foi instalado no período de agosto a novembro de 2002, época de estiagem na região, no pomar de plantas jovens, devido à relativa facilidade com que elas podem ser submetidas a estresse hídrico.

Foram utilizadas oito plantas, seis das quais utilizadas para medir a transpiração pelo método de dissipação de calor, concomitantemente com medidas dendrométricas e duas para medir o gradiente térmico natural do caule. Os sensores de fluxo de seiva foram instalados logo abaixo do ponto de enxerto, devido à maior uniformidade do caule nesse ponto. A irrigação foi feita manualmente e o monitoramento do solo foi realizado através de 4 tensiômetros em cada planta, a 0,10;0,20; 0,30 e 0,50 m de profundidade, a uma distância de $30 \mathrm{~cm}$ do caule. Uma das plantas, testemunha, foi mantida sempre irrigada e em condições ótimas de disponibilidade hídrica do solo, para evitar déficit de transpiração, enquanto que a as outras eram irrigadas somente após de ter sofrido déficit hídrico, quando o potencial mátrico na profundidade de $20 \mathrm{~cm}$ se aproximava de $-0,08 \mathrm{MPa}$.

Para maior controle de entrada de água de chuva na área de absorção radicular, foram isoladas três plantas com lâmina plástica, em forma de cilindro de 1,2 m de diâmetro, até uma profundidade de $60 \mathrm{~cm}$. Com isto foi garantido o estresse hídrico das plantas, de forma intermitente, evitando a interferência das chuvas. Na Figura 5 são mostrados detalhes do experimento em forma esquemática.

De acordo ao objetivo principal do presente trabalho, foram relacionados os parâmetros dendrométricos, amplitude diária de contração (ADC), a variação do diâmetro máximo (DMax) e a variação do diâmetro mínimo (DMin) com o déficit hídrico da planta, 
através de um indicador direto ou seja, a transpiração relativa (TRR) diária, baseada na medida de fluxo de seiva.

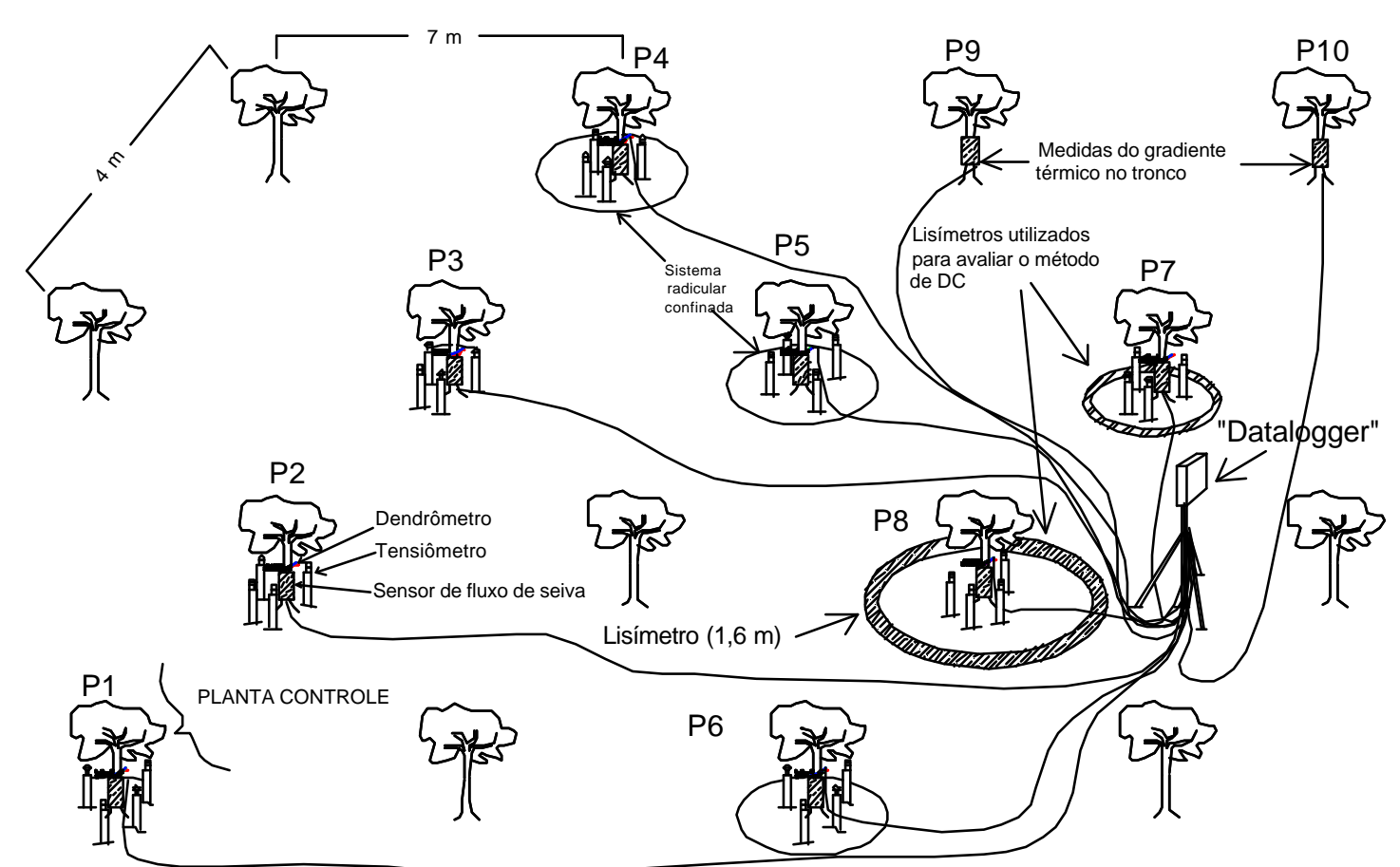

Figura 5 - Visão esquemática do experimento no pomar de plantas jovens. Observa-se os sensores instalados em cada planta, as plantas isoladas e os dois lisímetros que foram utilizados para testar o método de fluxo de seiva.

$$
\mathrm{TRR}=\mathrm{TR} / \mathrm{TP}
$$

onde TR é a transpiração da planta estudada e TP é a transpiração potencial dessa planta, considerado como sendo aquela obtida na planta-controle.

Como as plantas envolvidas no experimento tinham áreas foliares diferentes, obviamente tiveram valores de TP diferentes, de modo que nas avaliações comparativas foram utilizados os valores de fluxo de seiva por unidades de área foliar de cada planta. Para solucionar esta inconveniência, foi feita uma relação entre a TP e a área foliar da planta estudada e da planta-controle. Devido as taxas de crescimento, tanto da área foliar como do diâmetro do caule, serem diferentes entre plantas, a determinação dessas variáveis foi feita através de modelos estabelecidos com base em quatro medições realizadas durante o 
experimento. Observando a Figura 6 percebe-se a diferença de crescimento de uma das plantas entre o começo (a) e final (b) do experimento.

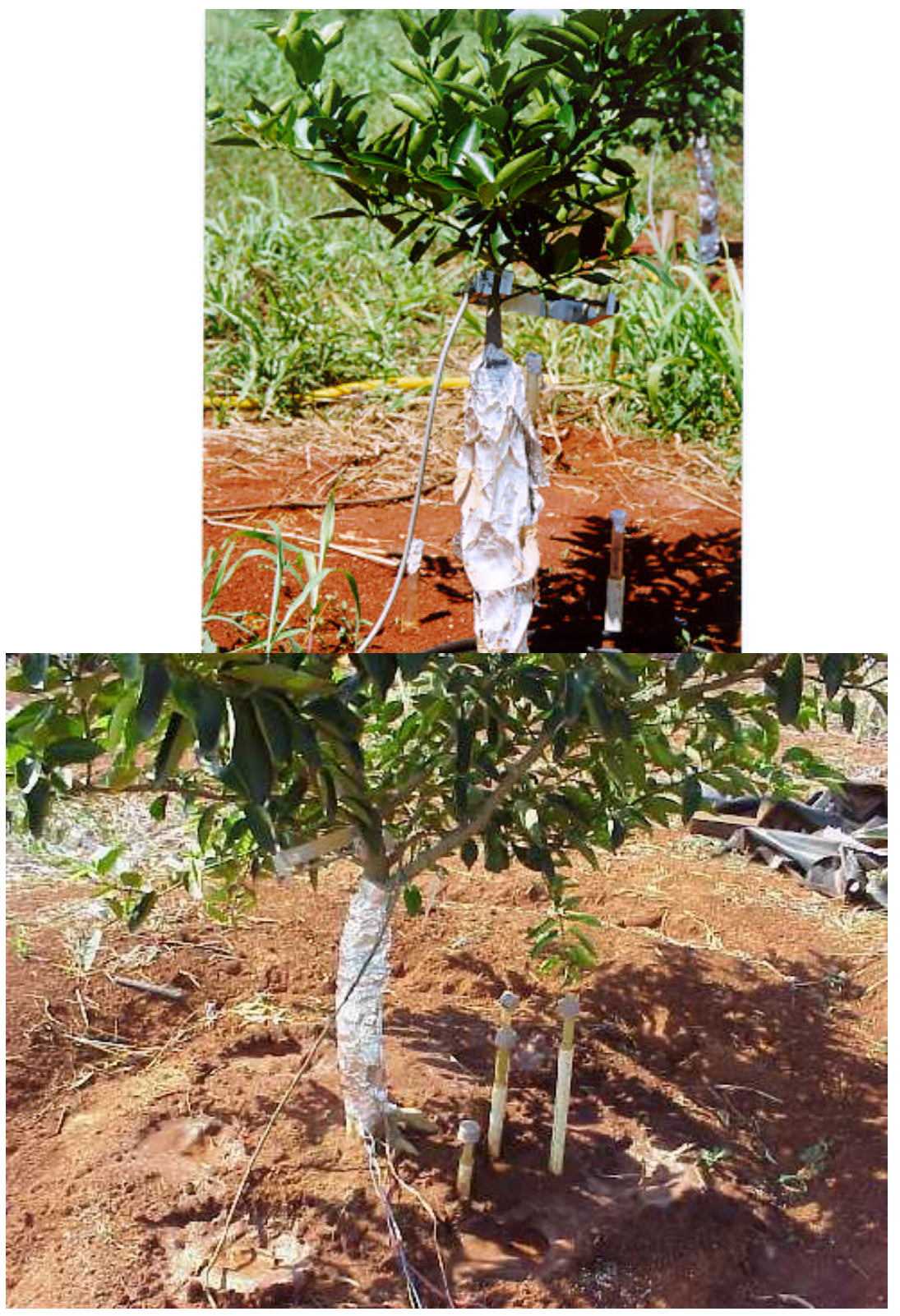

Figura 6 - Uma planta com o sensor de fluxo de seiva, dendrômetro e tensiômetros instalados, no começo (a) e no final do experimento (b). Ver a diferença de crescimento. 


\section{RESULTADOS E DISCUSSÃO}

\subsection{Determinação do fluxo de seiva}

\subsubsection{Avaliação do desempenho do método de balanço de calor em plantas adultas}

Uma das formas de se verificar se o sensor de fluxo de seiva por balanço de calor está tendo desempenho adequado é analisar os valores de temperatura envolvidos nos cálculos do método. Por exemplo, certo comportamento, como o da curva correspondente à diferença de temperatura entre o extremo superior e inferior do segmento aquecido de caule, S-I da Figura 7, chama a atenção. Observa-se que nas primeiras horas do período matutino, a curva tem uma progressão vertical muito rápida (seta). Shackel et al. (1992), verificaram que este comportamento anormal conduz a superestimativa da taxa de fluxo de seiva, nesse período de tempo. Com maior detalhe

pode ser verificada na Figura 8 (seta), que entre 9 e 10 horas ocorre um "pico" que aparentemente destaca-se do padrão de variação esperado no período. Nos gráficos apresentados por Silva et al. (2000), embora não sendo comentado pelos autores, também é observado claramente esse comportamento.

Tal comportamento pode ser explicado ao se considerar que, logo após o amanhecer, quando a planta começa a transpirar, o fluxo de seiva começa a aumentar, partindo de uma velocidade mínima (podendo ser nula). Esta seiva não aquecida (seiva fresca), ao atingir a parte inferior do segmento aquecido, provoca queda drástica da temperatura naquele ponto, elevando rapidamente a diferença entre a temperatura deste ponto e a do extremo superior do segmento. Com a dissipação de calor convectivo, promovido pelo aumento subsequente do fluxo de seiva, o valor de $\mathrm{T}-\mathrm{c}-\mathrm{Tb}$ tende a diminuir, voltando, portanto a sua tendência normal. 


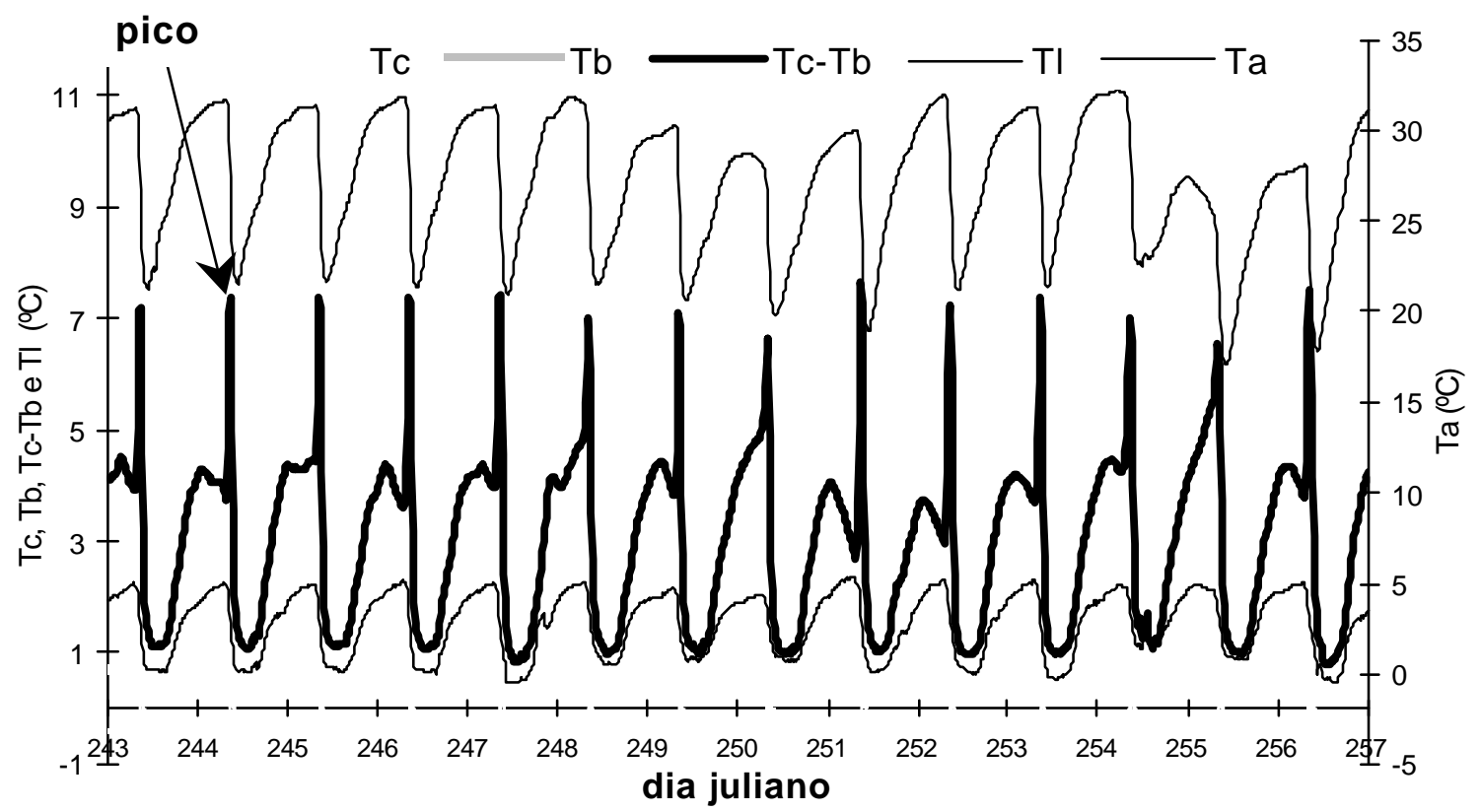

Figura 7 - Medidas térmicas envolvidas na medida de fluxo de seiva pelo método de balanço de calor (veja figura 2). Medidas realizadas num ramo de lima ácida 'Tahiti' entre o 31 de agosto a 13 de setembro (DJ= 243 - 256) de 2001. Fazenda Areão, ESALQ/USP.

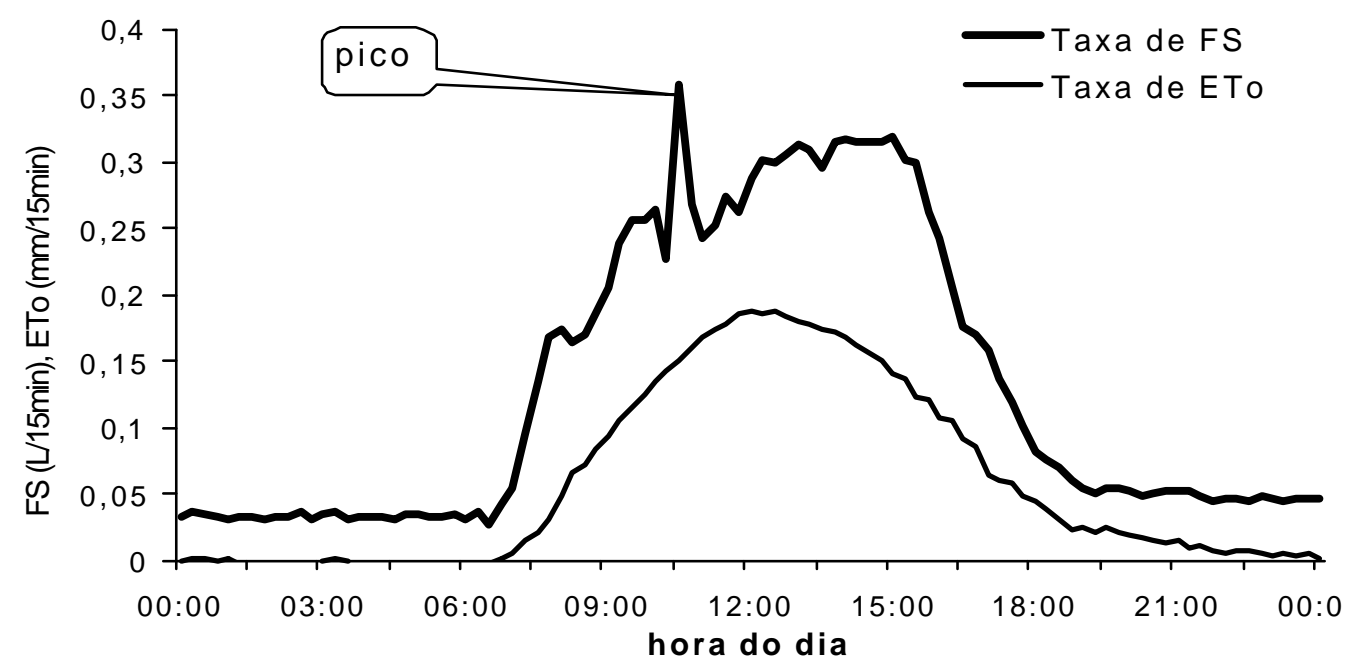

Figura 8 - Variação da taxa de fluxo de seiva (FS) e da evapotranspiração de referência (ETo), estimada pelo método de Penman-Monteith, ao longo do dia. Correspondente à planta 1 , ramo 1 , de lima ácida 'Tahiti', medida no dia 5 de setembro de 2001. Fazenda Areão, ESALQ/USP. 
A Figura 9 mostra a variação da taxa de fluxo de seiva em um ramo de lima ácida 'Tahiti' adulta ao longo do tempo, em vários dias. Com a finalidade de apoiar a discussão sobre a evolução dos valores, a figura mostra, também, a variação da evapotranspiração potencial ou de referência (ETo) calculada a intervalos de 15 minutos.

Verifica-se uma certa defasagem temporal entre as curvas, principalmente na ocorrência de pico dos valores e no período da tarde. Essa defasagem pode ocorrer porque o fluxo de seiva não acompanha exatamente a demanda atmosférica, em função das resistências hidráulicas encontrada nas plantas, sendo comum encontrar-se defasagem entre esse fluxo na fase líquida e o fluxo transpiratório (na fase gasosa), conforme já demonstrado por vários autores (Steinberg et al., 1989; Valancogne \& Nasr, 1993; Weibel \& de Vos, 1994; Herzog et al., 1997).

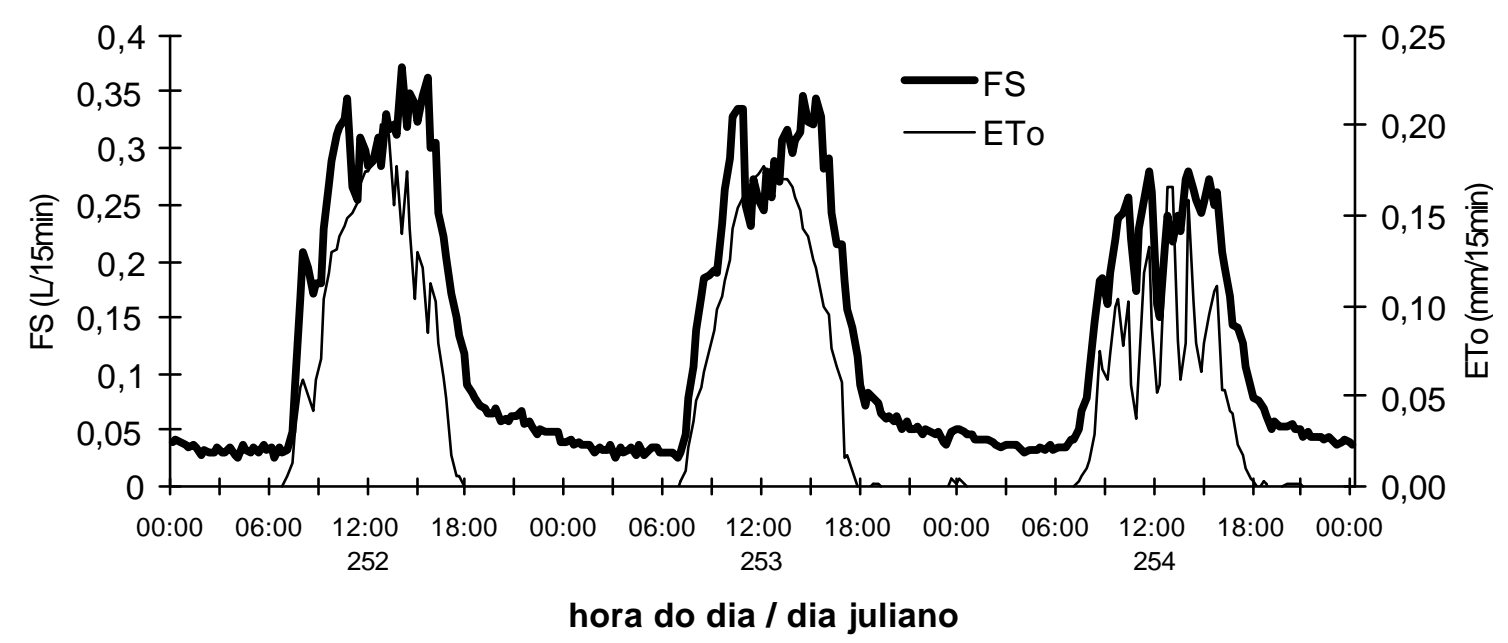

Figura 9 - Variação do fluxo de seiva (FS) e da evapotranspiração potencial (ETo), correspondente à planta 1 , ramo 1 , de lima ácida 'Tahiti', medidas entre os dias 9 e 11 de setembro de 2001 (DJ=252-254). Fazenda Areão, ESALQ/USP.

Portanto, a pequena defasagem mostrada na figura, principalmente nos horários de pico das curvas, pode ser explicada pela defasagem entre o fluxo de seiva e a transpiração, caso se assuma que esta última ocorre em fase com a demanda atmosférica (representado por ETo). A associação entre a transpiração e a ETo pode ser modificada caso haja redução da abertura estomática nas horas de maior demanda atmosférica. 
A ocorrência de valores de fluxo de seiva à noite também merece discussão. Dentro do contexto de defasagem temporal entre a transpiração e o fluxo de seiva, a ocorrência deste último à noite é justificável, pois representa a fase da dinâmica hídrica diária na qual a planta se recupera da perda diurna de água, em consequiência da maior transpiração em relação à absorção nesse período. Desse modo, os tecidos do caule e ramos, além das folhas, recuperam sua turgescência. Essa dinâmica hídrica explica as variações micromorfométricas em escala diária, uma das quais é o processo de contração/expansão radial dos ramos e caules.

As medidas diretas no campo de absorção e transpiração de árvores grandes, como as usadas para estudo do desempenho do método de balanço de calor, são difíceis de serem realizadas. A falta delas no presente estudo dificulta uma avaliação mais profunda do desempenho do método. Torna-se difícil neste ponto concluir se a magnitude de fluxo de seiva noturno observada é justificável, pois os valores estão na faixa de grandeza em que os erros relativos do método são grandes. Entretanto, a princípio, a evolução diária do fluxo de seiva mostra coerência com o esperado e uma maior discussão do desempenho, incluindo-se fluxos noturnos, será feita em comparação ao método de dissipação de calor.

O método de balanço de calor, embora de princípio simples, necessita de medidas que demandam certa complexidade técnica. Qualquer problema em uma delas inviabiliza a estimativa do fluxo total de seiva. Um desses problemas aconteceu quando um dos termopares, que media a Tc (vide Figura 2) do ramo 1 da planta 2, teve inadequado contato (ora fechava o circuito, ora não), prejudicando a estimativa de fluxo de seiva total dessa planta.

Para não se perder toda a medida da árvore, já que houve a medida em três outros ramos, o fluxo de siva no ramo com problema foi estimado a partir da correlação entre o fluxo de seiva médio diário dos outros sete ramos de medida e de seus respectivos diâmetros (Figura 10). 




Figura 10 - Relação entre a transpiração (fluxo de seiva) medida pelo método de balanço de calor e o diâmetro do ramo em plantas adultas.

Baseando-se no fato da boa correlação encontrada, ela foi usada para estimar o fluxo médio diário no período. A estimativa do valor para um dia específico para o ramo foi realizada pelo uso de um fator $f$, que considera proporcionalidade entre a transpiração daquele ramo.

$$
\mathrm{f}=-\mathrm{Tr} *[(\mathrm{Tm}-\mathrm{Tt}) / \mathrm{Tm}]
$$

onde: Tr é a transpiração do ramo 1 da planta calculada através da equação linear da Figura 10, Tm é a transpiração média diária dos 7 ramos de todo o período e Tt é a soma da transpiração nos sete ramos no dia em que se quer estimar a transpiração para aquele ramo, cujo diâmetro foi de $12 \mathrm{~cm}$. Desta maneira se tem o fator f para cada dia específico o qual é somado algebricamente ao valor de Tr, obtido através da equação linear da Figura 10 (Tabela 1).

A Tabela 1 mostra os valores diários do fluxo de seiva, assumidos como representativos da transpiração e estimados pelo método de balanço de calor. Embora não tenha havido determinações de transpiração ou de fluxo de seiva por um método independente, os resultados podem ser comparados àqueles obtidos por Marin et al. (2002) no mesmo pomar, sob condições de irrigação, em dois períodos, no verão (do $15^{\circ}$ ao $49^{\circ}$ dia do ano) e no inverno $\left(174^{\circ}\right.$ ao $195^{\circ}$ dia do ano), em duas árvores com área foliar de $48 \mathrm{~m}^{2}$ e $99 \mathrm{~m}^{2}$ no verão, e $64 \mathrm{~m}^{2}$ e $87 \mathrm{~m}^{2}$ no inverno de 2000. Considerando que as árvores tinham áreas foliares parecidas, estimou-se um valor próximo a $150 \mathrm{~m}^{2}$ para 
as duas árvores do presente estudo, valor que foi confirmado posteriormente (veja item seguinte) e a comparação pode ser feita, considerando-se o fluxo de seiva (determinado pelo método de balanço de calor) por unidade de área foliar. Os valores da Tabela 1 levam à média de $0,89 \mathrm{~L} \mathrm{~m}^{-2} \mathrm{~d}^{-1}$, contra $1,1 \mathrm{~L} \mathrm{~m}^{-2} \mathrm{~d}^{-1}$ no período de verão e $0,4 \mathrm{~L} \mathrm{~m}^{-2} \mathrm{~d}^{-1}$ no período de inverno encontrados no trabalho de Marin et al. (2002). Considerando-se as diferenças de épocas, o valor médio encontrado neste trabalho parece coerente com os dos citados autores, pois foram obtidos em época intermediária às utilizadas por eles no ano de 2000. Deve-se considerar que o aumento da área foliar para valores tão grandes, como $150 \mathrm{~m}^{2}$, pode interferir com o saldo de radiação da copa, no sentido de diminuir o saldo médio por unidade de área foliar devido ao adensamento e o auto-sombreamento no interior da copa. Por outro lado, no período de estudo do presente trabalho, a ETo média diária de 4,69 $\mathrm{mm} \mathrm{d}^{-1}$ mostrou-se superior aos valores verificados em 2000 por Marin et al. (2002) (4,29 $\mathrm{mm} \mathrm{d}^{-1}$ no verão e $2,33 \mathrm{~mm} \mathrm{~d}^{-1}$ no inverno).

Tabela 1. Valores de transpiração (fluxo de seiva) diários $\left(\mathrm{L} \mathrm{d}^{-1}\right)$ medidos em duas plantas adultas de lima ácida 'Tahiti', com 4 ramos cada uma, determinados através do método de balanço de calor, no período compreendido entre 31 de agosto e 13 de setembro de2001 (dias juliano DJ, entre 243 e 256).

\begin{tabular}{rrrrrrrrrrrrrr}
\hline \multicolumn{1}{c}{ PLANTA 1 } & \multicolumn{1}{c}{ PLANTA2 } \\
DJ & Ramo1 & Ramo 2 & Ramo3 & Ramo4 & TOTAL & Ramo1 & Ramo 2 & Ramo3 & Ramo4 & TOTAL & mm/dia \\
\hline 243 & 12,20 & 97,05 & 28,96 & 4,55 & $\mathbf{1 4 2 , 7 6}$ & 45,84 & 35,48 & 33,54 & 14,93 & $\mathbf{1 3 0 , 4 1}$ & 4,56 \\
244 & 12,13 & 95,90 & 28,24 & 4,36 & $\mathbf{1 4 0 , 6 3}$ & 45,95 & 35,50 & 35,79 & 15,33 & $\mathbf{1 3 3 , 1 9}$ & 4,63 \\
245 & 12,30 & 95,06 & 29,64 & 4,30 & $\mathbf{1 4 1 , 3 0}$ & 46,64 & 36,11 & 36,94 & 16,34 & $\mathbf{1 3 6 , 6 7}$ & 4,93 \\
246 & 12,38 & 93,88 & 29,63 & 4,37 & $\mathbf{1 4 0 , 2 6}$ & 45,50 & 35,39 & 33,10 & 16,28 & $\mathbf{1 3 0 , 8 8}$ & 4,84 \\
247 & 15,01 & 106,28 & 32,53 & 5,57 & $\mathbf{1 5 9 , 3 9}$ & 49,78 & 35,10 & 35,82 & 15,87 & $\mathbf{1 3 7 , 2 4}$ & 5,63 \\
248 & 12,72 & 88,05 & 32,44 & 4,65 & $\mathbf{1 3 7 , 8 6}$ & 46,23 & 35,11 & 39,71 & 15,98 & $\mathbf{1 3 7 , 0 8}$ & 5,64 \\
249 & 12,15 & 83,34 & 32,75 & 4,85 & $\mathbf{1 3 3 , 0 9}$ & 43,99 & 32,55 & 37,57 & 14,36 & $\mathbf{1 2 9 , 0 8}$ & 4,39 \\
250 & 12,87 & 84,70 & 35,70 & 4,07 & $\mathbf{1 3 7 , 3 4}$ & 46,29 & 34,23 & 39,99 & 17,37 & $\mathbf{1 3 8 , 5 0}$ & 4,80 \\
251 & 11,60 & 68,01 & 28,41 & 4,02 & $\mathbf{1 1 2 , 0 4}$ & 37,87 & 31,93 & 30,41 & 12,91 & $\mathbf{1 1 3 , 6 4}$ & 4,53 \\
252 & 13,56 & 96,32 & 33,69 & 4,37 & $\mathbf{1 4 7 , 9 4}$ & 48,68 & 34,08 & 43,59 & 15,15 & $\mathbf{1 4 2 , 1 6}$ & 4,42 \\
253 & 12,84 & 90,27 & 28,94 & 4,11 & $\mathbf{1 3 6 , 1 6}$ & & - & - & - & & 4,47 \\
254 & 10,76 & 78,52 & 29,83 & 4,42 & $\mathbf{1 2 3 , 5 3}$ & & - & - & - & & 2,86 \\
255 & 11,00 & 65,31 & 32,59 & 3,80 & $\mathbf{1 1 2 , 7 0}$ & & - & - & - & & 5,16 \\
256 & 13,52 & 80,64 & $\mathbf{3 2 , 0 8}$ & 4,49 & $\mathbf{1 3 0 , 7 3}$ & 42,65 & 33,14 & 31,03 & 16,04 & $\mathbf{1 2 3 , 4 4}$ & 4,90 \\
Total & $\mathbf{1 7 5 , 0 4}$ & $\mathbf{1 2 2 3 , 3 3}$ & $\mathbf{4 3 5 , 4 3}$ & $\mathbf{6 1 , 9 3}$ & $\mathbf{1 8 9 5 , 7 3}$ & $\mathbf{4 9 9 , 4 2}$ & $\mathbf{3 7 8 , 6 2}$ & $\mathbf{3 9 7 , 4 9}$ & $\mathbf{1 7 0 , 5 6}$ & $\mathbf{1 4 3 9 , 0 6}$ & \\
Média & $\mathbf{1 2 , 5 0}$ & $\mathbf{8 7 , 3 8}$ & $\mathbf{3 1 , 1 0}$ & $\mathbf{4 , 4 2}$ & $\mathbf{1 3 5 , 4 1}$ & $\mathbf{4 5 , 4 0}$ & $\mathbf{3 4 , 4 2}$ & $\mathbf{3 6 , 1 4}$ & $\mathbf{1 5 , 5 1}$ & $\mathbf{1 3 0 , 8 2}$ & $\mathbf{4 , 6 9}$ \\
\hline
\end{tabular}


Considerando todos aspectos mencionados, é possível inferir que os valores de fluxo de seiva observados em 2002 estão dentro da magnitude esperada.

\subsubsection{Avaliação do desempenho do método de dissipação térmica e comparação com o método de balanço de calor em plantas adultas}

Foi feita a avaliação do método de dissipação térmica em 4 plantas adultas e uma comparação entre esse método e o balanço de calor em 1 ramo. Para tal foram estimadas as áreas foliares das árvores, com base em medidas diretas da área foliar de três ramos da planta 4, cujos valores foram 2,4 $\mathrm{m}^{2}, 9,6 \mathrm{~m}^{2}$ e 18,1 $\mathrm{m}^{2}$, sendo o diâmetro desses ramos $2,2 \mathrm{~cm}, 4,8 \mathrm{~cm}$ e $6,5 \mathrm{~cm}$, respectivamente. Estas medidas diretas foram realizadas com a contagem de todas as folhas, multiplicando-se o número de folhas pela área média das mesmas, determinada através da equação 16. Assumindo uma relação direta entre o diâmetro do ramo e sua área foliar, a partir das relações entre essas duas variáveis nesses três ramos (fig. 11), foi estimada a área foliar de cada ramo, utilizando o diâmetro dos mesmos para compor a área total de cada planta (Tabela 2). $\mathrm{O}$ diâmetro medido em cada ramo corresponde ao ponto de instalação de cada sensor de fluxo de seiva (Tabela 2).

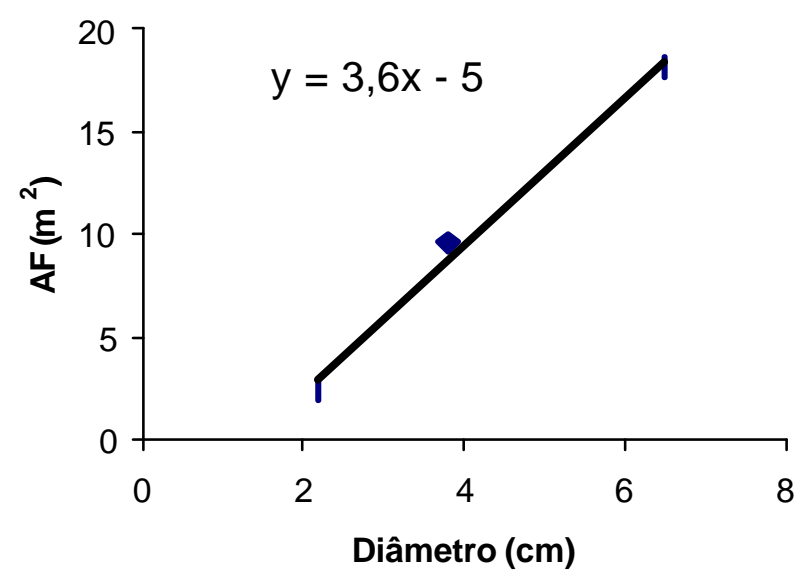

Figura 11 - Relação entre o diâmetro e a área foliar de três ramos de lima ácida 'Tahiti', medidos durante o mês de outubro de 2002. Fazenda Areão, ESALQ/USP. 
Tabela 2. Diâmetro e área foliar (AF) dos ramos $\left(\mathrm{R}_{\mathrm{i}}\right)$ correspondente a 4 plantas de lima ácida 'Tahiti'. AF determinado através da equação linear da Figura 11.

\begin{tabular}{|c|c|c|c|c|c|c|c|}
\hline & & $\mathrm{R} 1$ & $\mathrm{R} 2$ & R3 & $\mathrm{R} 4$ & R5 & AF/planta \\
\hline \multirow[t]{2}{*}{ P1 } & Diâmetro $(\mathrm{cm})$ & 11,83 & 6,92 & 8,02 & 10,15 & 11,94 & \\
\hline & $\mathrm{AF}\left(\mathrm{m}^{2}\right)$ & 37,57 & 19,92 & 23,88 & 31,55 & 37,97 & 150,9 \\
\hline \multirow[t]{2}{*}{ P2 } & Diâmetro $(\mathrm{cm})$ & 7,77 & 12,73 & 13,85 & & & \\
\hline & $\mathrm{AF}\left(\mathrm{m}^{2}\right)$ & 22,96 & 40,84 & 44,85 & & & 108,6 \\
\hline \multirow[t]{2}{*}{ P3 } & Diâmetro $(\mathrm{cm})$ & 12,29 & 11,65 & 6,49 & 8,55 & & \\
\hline & $\mathrm{AF}\left(\mathrm{m}^{2}\right)$ & 39,23 & 36,94 & 18,38 & 25,77 & & 120,3 \\
\hline \multirow[t]{2}{*}{ P4 } & Diâmetro $(\mathrm{cm})$ & 10,66 & 16,31 & 7,70 & 6,50 & & \\
\hline & $\mathrm{AF}\left(\mathrm{m}^{2}\right)$ & 33,39 & 53,73 & 22,73 & 18,40 & & 128,2 \\
\hline
\end{tabular}

Observação: a P4 corresponde à P1 do item anterior mas, com um ramo menos, devido ao corte de um deles durante a experimentação no 2002; daí a diminuição da $\mathrm{AF}$ que foi estimado em $150 \mathrm{~m}^{2}$ no ano anterior.

Nas Figuras 12 e 13 pode ser observada a evolução temporal do fluxo de seiva durante três dias, em 4 plantas adultas, com 5, 3, 4 e 4 ramos, respectivamente, pelo método da dissipação térmica.

A notável diferença entre a transpiração das plantas 2 e 3, demonstra que o método detectou de forma coerente as alterações da condição hídrica da planta. Observese que a planta 2, com boa irrigação, apesar de ter menor área foliar, transpirou muito mais do que a planta 3, que estava com deficiência hídrica (Tabela 3). O fato é que entre os dias 16 e 17 de outubro todas a plantas, exceto a 3, foram irrigadas com 840 litros de água cada uma. A medida do potencial mátrico da água no solo na planta 2 nos três dias indicou os seguintes valores: $-25 ;-46 ;-29$ e $-36 \mathrm{kPa}$, para 0,10;0,20;0,30 e 0,50 m de profundidades, para a planta 3 indicou $-45 ;-60 ;-78$ e $-82 \mathrm{kPa}$, respectivamente, nas mesmas profundidades. 


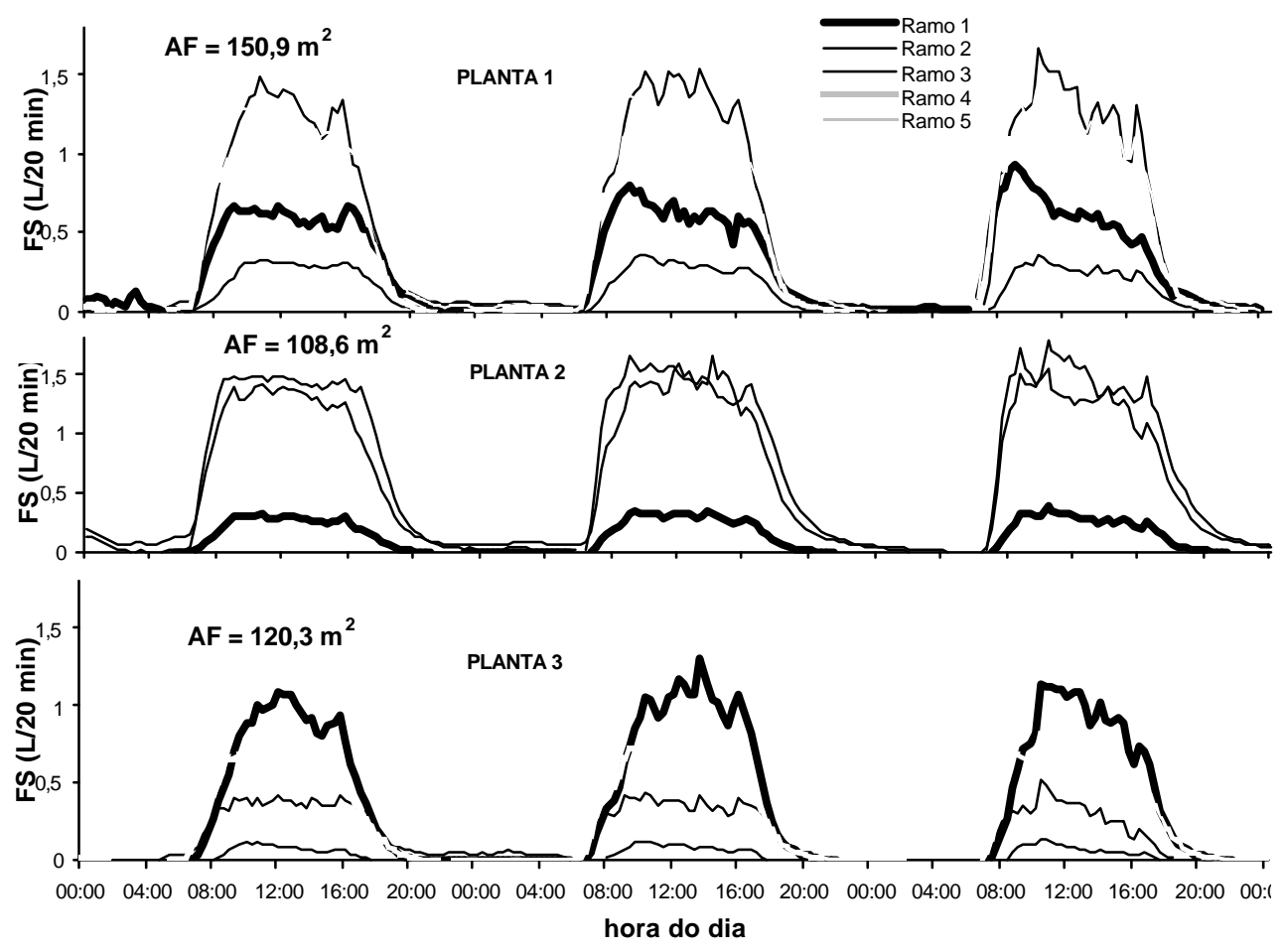

Figura 12 - Variação do fluxo de seiva em 3 plantas adultas de lima ácida 'Tahiti', com 5, 3 e 4 ramos, respectivamente; medidas realizadas ao longo dos dias 17, 18 e 19 de outubro de 2002. Fazenda Areão, ESALQ/USP. Determinado pelo método de dissipação térmica.

Para comparar as medidas de fluxo de seiva em plantas com áreas foliares diferentes, o ramo 4 da planta 4 foi desfolhado gradualmente durante os dias 18, 19 e 20 de outubro. A respeito, é interessante observar a coerência da medida de fluxo de seiva nesse ramo, cujo valor foi diminuindo de forma gradativa (Figura 13 e Tabela 3), acompanhando esse desfolhamento, demonstrando a sensibilidade do método em responder as alterações no tamanho da área foliar. 


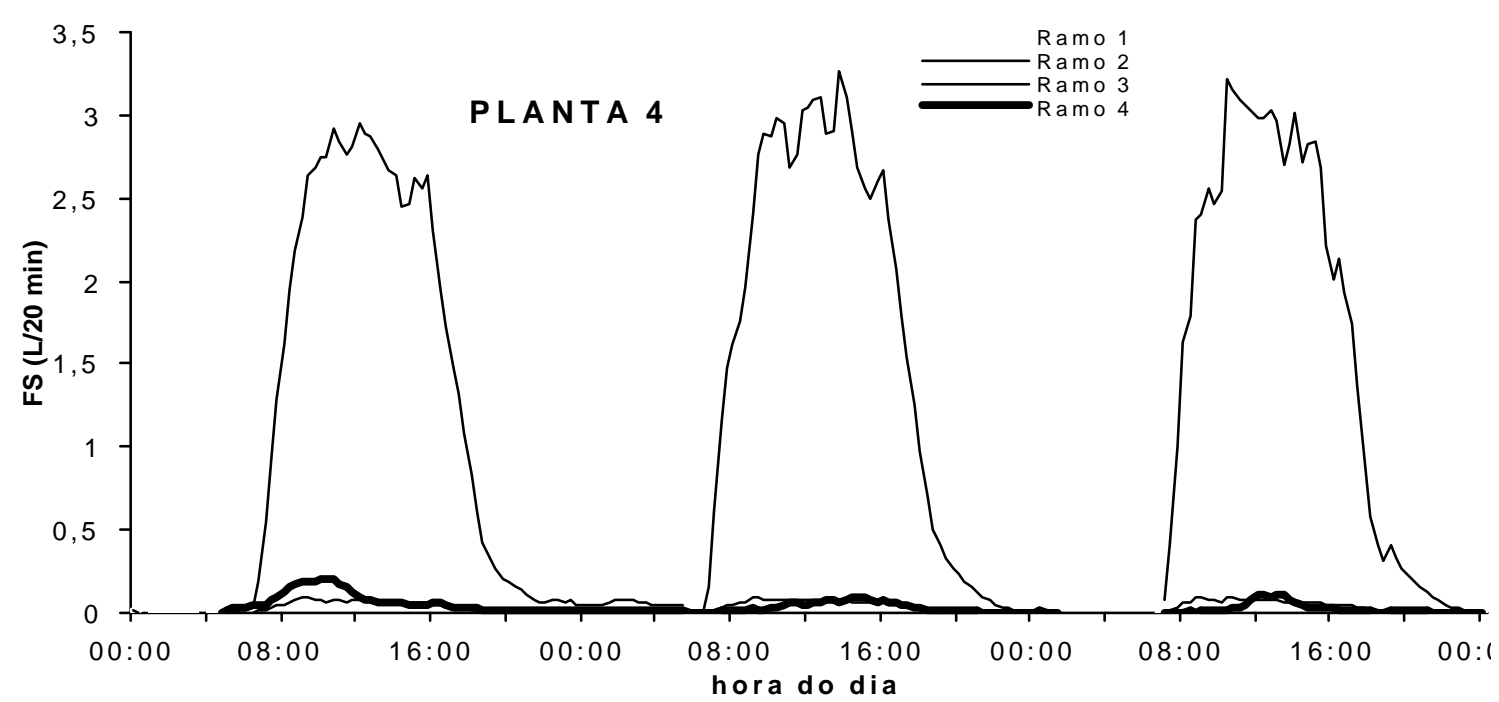

Figura 13 - Variação do fluxo de seiva em uma planta adulta de lima ácida 'Tahiti', com 4 ramos, medidas realizadas ao longo dos dias 17, 18 e 19 de outubro de 2002. Fazenda Areão, ESALQ/USP. Determinado pelo método de dissipação térmica.

Tabela 3. Fluxo de seiva determinado pelo método de dissipação térmica, em quatro plantas de lima ácida 'Tahiti', durante três dias. Fazenda Areão, ESALQ/USP. 2002.

\begin{tabular}{rrrrrrrr}
\hline & & $\mathrm{R} 1$ & $\mathrm{R} 2$ & $\mathrm{R} 3$ & $\mathrm{R} 4$ & $\mathrm{R} 5$ & Total/planta \\
\hline \multirow{2}{*}{ Planta1 } & 17/out. & 21,2 & 37,8 & 8,7 & 31,8 & 39,9 & 139,5 \\
& 18/out. & 21,4 & 41,1 & 8,9 & 34,2 & 40,9 & 146,6 \\
& 19/out. & 21,4 & 38,4 & 7,8 & 32,9 & 38,8 & 139,3 \\
Planta 2 & 17/out. & 8,3 & 44,2 & 49,3 & & & 101,8 \\
& 18/out. & 8,9 & 46,2 & 50,5 & & & 105,6 \\
& 19/out. & 8,4 & 45,0 & 47,0 & & & 100,4 \\
Planta3 & 17/out. & 24,3 & 12,9 & 2,1 & 18,7 & & 57,9 \\
& 18/out. & 28,1 & 12,9 & 2,3 & 20,4 & & 63,7 \\
& 19/out. & 25,2 & 9,4 & 2,0 & 19,5 & & 56,2 \\
Planta 4 4 & 17/out. & 25,9 & 79,2 & 2,0 & 3,8 & & 110,9 \\
& 18/out. & 27,8 & 85,5 & 2,1 & 2,0 & & 117,5 \\
& 19/out. & 25,3 & 79,9 & 2,1 & 1,3 & & 108,6 \\
\hline
\end{tabular}

A Figura 14 mostra a relação entre os valores de fluxo de seiva determinados pelos dois métodos, com sensores instalados em um mesmo ramo. Observa-se que houve uma dispersão grande dos dados e uma tendência de superestimativa média de $35 \%$ dos 
valores calculados pelo método de balanço de calor em relação aos de dissipação térmica, que não pode ser imputada à diferença de localização dos sensores no ramo.

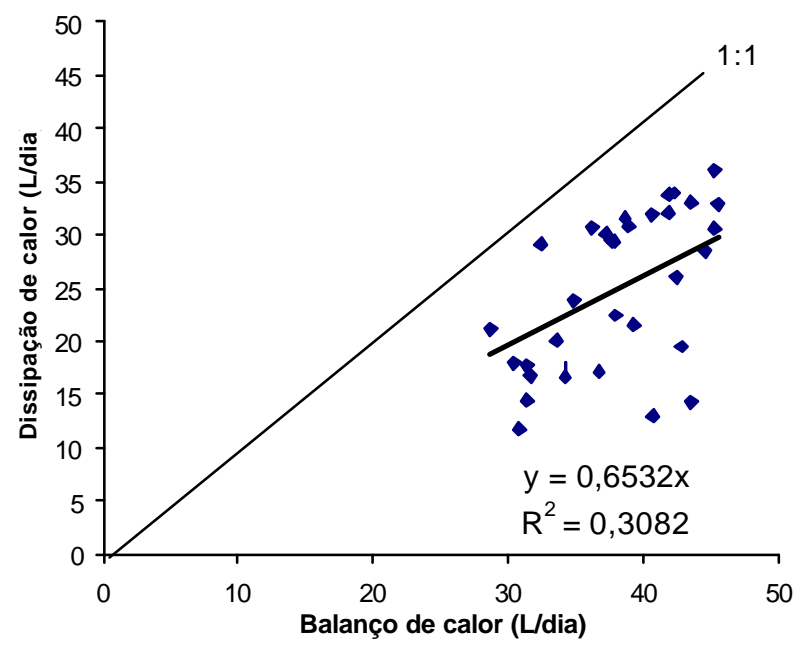

Figura 14 - Relação entre medidas de fluxo de seiva (L/dia) realizadas pelo método de balanço de calor e pelo método de dissipação de calor. Medidas realizadas num ramo de lima ácida 'Tahiti' durante 33 dias. Fazenda Areão, ESALQ/USP.

Analisando-se a Figura 15, que mostra a variação temporal do fluxo de seiva medida pelos dois métodos ao longo de cinco dias, as discrepâncias entre eles ocorrem basicamente por valores mais elevados medidos pelo método de balanço de calor no período noturno e no período do meio da manhã.

Embora a reposição noturna seja um fato real já conhecido (Steinberg et al., 1989; Valancogne \& Nasr, 1993; Herzog, 1997; Grime \& Sinclair, 1999), é difícil avaliar se a magnitude da medida à noite pelo método de balanço de calor é confiável, pois o fluxo é relativamente pequeno, em faixa de valores em que a sensibilidade dos métodos é diminuída. Neste estudo, a ordem de grandeza de fluxo médio no período entre 18 horas de um dia e 6 horas do dia seguinte, em 5 dias foi em média 7,25 L pelo método de balanço de calor, representando cerca de $20 \%$ do fluxo de seiva integrado no dia, enquanto pelo método de dissipação térmica foi muito menor, 2,15 L, representando apenas $7 \%$ do total de 24 horas. 


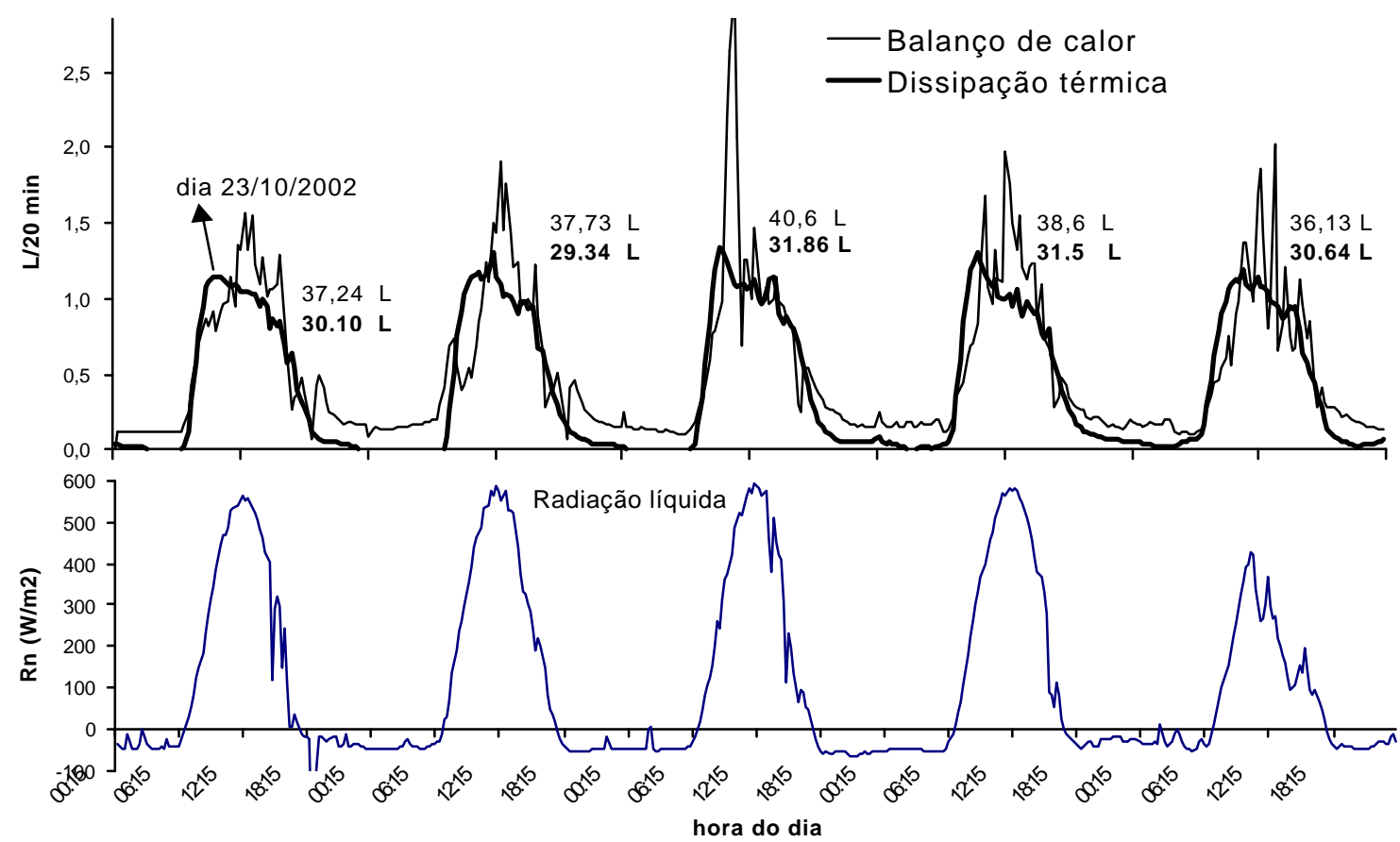

Figura 15 - Variação das medidas de fluxo de seiva (L/20min), pelos métodos de balanço de calor e de dissipação de calor, realizadas num ramo de lima ácida 'Tahití', entre 23 e 27 de outubro de 2002. É mostrada, também, a variação da radiação líquida sobre gramado. Fazenda Areão, ESALQ/USP.

A magnitude do fluxo de seiva noturno é variável em função de vários fatores, dentre eles a época do ano, disponibilidade hídrica do solo e dimensão da árvore. Isto torna difícil a comparação com dados de literatura, pela diferença de tamanho, de espécie, de condições experimentais e mesmo da forma de expressão do fluxo.

Os dados de fluxo noturno encontrados na literatura são pouco informativos e de difícil comparação por terem sido obtidos sob outras condições climáticas, de espécie e de tamanho da planta, em relação às do presente trabalho. Para roseira em casadevegetação, Seginer (1984) encontrou transpiração noturna representando cerca de $10 \%$ da transpiração total do dia. Green et al. (1988) trabalhando com kiwi (diâmetro aproximado de $60 \mathrm{~mm}$ ) e macieira (diâmetro de $82 \mathrm{~mm}$ ) encontrou no verão fluxos de seiva noturno determinado por um terceiro método térmico (pulso de calor) representando, respectivamente para cada espécie, 19\% e 6\% do fluxo diário, em média para 15 dias de verão da Nova Zelândia. Em plantação de Eucaliptus grandis, Benyon 
(1999) encontrou em 24 dias de nnverno na Austrália, um valor médio de fluxo de seiva determinado pelo método de pulso de calor, equivalente a $5 \%$ da transpiração total diária, sendo que em dois dias o valor do período noturno foi elevado, chegando ao equivalente à lâmina de água de $0,8 \mathrm{~mm}$ (não há possibilidade de transformar em volume, por falta de informação sobre espaçamento). Os dados obtidos no presente estudo pelos dois métodos usados encaixam-se dentro dos valores relativos acima citados, não permitindo maior discussão apoiada na literatura quanto ao método que fornece valores noturnos mais confiáveis em citros.

Nos sensores de balanço de calor comercializados (Dynamax INC, s/d), o fabricante recomenda que se o valor noturno do fluxo de calor estimado como sendo transportado pela seiva (Qs) for menor que 0,2 da potência (calor) fornecida e se a diferença de temperatura entre as extremidades do segmento aquecido, Tc-Tb (ver eq. 9), for menor que $0,75{ }^{\circ} \mathrm{C}$, deve-se adotar valor de fluxo de seiva nulo, já que a diminuição de Tc-Tb é causada pelo armazenamento de calor no volume de caule ou ramo amostrado. Quando esse valor (de Tc-Tb) torna-se pequeno, ele introduz uma estimativa de fluxo de seiva $(\mathrm{F})$ irrealmente alta, pois $\mathrm{Tc}-\mathrm{Tb}$ entra como denominador na equação de cálculo de F (ver eq. 10). Embora a adoção de fluxo de seiva nulo seja uma aproximação, é preferível adotá-la, pois se pode ter um erro maior causado por um valor baixo de Tc-Td, que eleva irrealmente o valor de F noturno.

Outro aspecto que pode ter contribuído para a discrepância dos valores diários dos dois métodos são picos em alguns dias, no método de balanço de calor, do início até a metade do período matutino, que podem ser evidência de ocorrência de problemas descritos no item 4.1.1 (ver Figura 8 e 9). Nos sensores comerciais, o fabricante (Dynamax INC, s/d) sugere que se adote nesses casos uma velocidade de pico de 0,42 $\mathrm{cm} / \mathrm{s}$, que seria a velocidade máxima da seiva que pode ser encontrada em lenhosas, ajustando os valores aparentemente excessivos para um valor limite de fluxo de seiva correspondente ao valor de velocidade acima citado. Os valores de pico mostrados na Figura 15 estão abaixo desse limite, entretanto, o pico observado no dia 25 de outubro 
parece excessivo, pois a variação da radiação líquida ao longo desse dia não justifica a existência dele.

Por outro lado, o método de dissipação de calor tem suas fontes de erro menos estudadas até agora que o de balanço de calor. Clearwater et al. (1999) discutem erros dessa técnica relacionados aos desvios na calibração universal usados, decorrentes do fato de que parte da sonda medidora pode ficar, na sua instalação no caule, em contato com o tecido não condutor. Outra fonte de erro pode ser a determinação da área efetiva de fluxo, que no presente trabalho foi considerada como a área de toda a seção reta do ramo. Outro aspecto a se considerar no método e que leva a erro de estimativa pode ser verificado na Figura 16, que mostra a variação do gradiente térmico natural nas plantas utilizado para tal determinação. Observa-se que o gradiente é maior à noite que no período diurno. Nota-se, também, na mesma figura que há relação entre a tendência do gradiente térmico, a orientação do ramo e o seu tamanho. Quanto menor o ramo, o gradiente pode ser maior e ele pode ser afetado pela orientação do ramo de maneira diferente. Por esse motivo, é recomendável que a correção devido ao gradiente deve ser feita a partir de medidas no próprio ramo, evitando extrapolações de um ramo para outro.

Se feitas as correções para os valores noturnos fornecidos pelo método de balanço de calor e, principalmente, as correções diurnas devidos ao gradiente térmico natural no método de dissipação, a discrepância entre ambos os métodos diminuiria bastante, mas não foi possível avançar até esse ponto no presente estudo, porque as medidas de gradiente térmico natural só foram realizadas posteriormente às medidas discutidas, quando o problema foi detectado. Ressalve-se que na literatura encontraramse observações sobre esse tipo de problemas (Granier, 1987; Ferreira \& Zitscher, 1996), mas apenas encontrou-se uma proposta de correção (Cabibel \& Do, 1991) através da introdução de mais um termo na equação universal em função da evapotranspiração de referência. Este tipo de proposta é difícil de ser adotada, antes de ser melhor estudada, por ter sido gerada em condições experimentais diferentes e para espécie de planta diferente da utilizada no presente trabalho. 


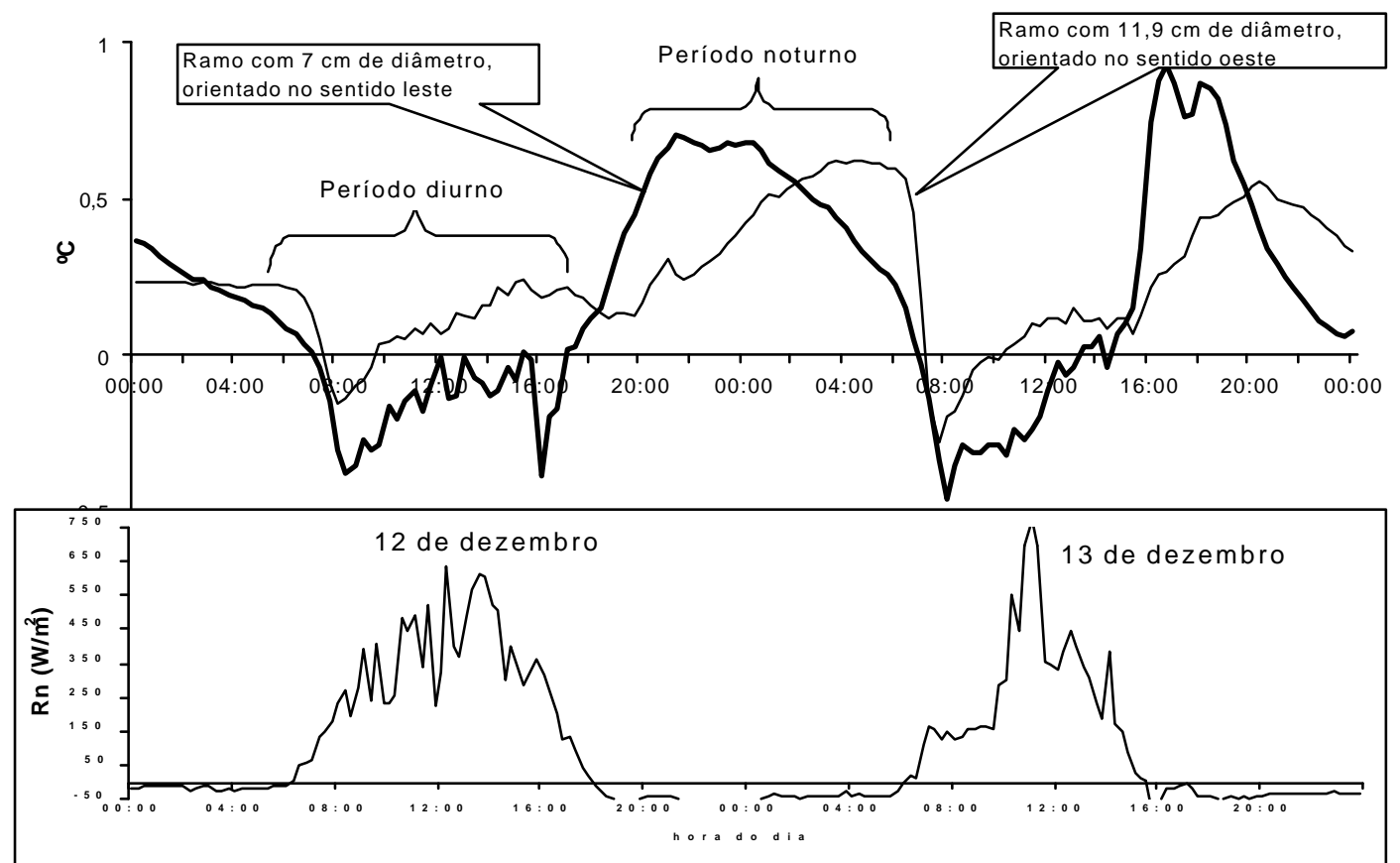

Figura 16 - Comportamento do gradiente térmico natural $\left({ }^{\circ} \mathrm{C} / 10 \mathrm{~cm}\right)$, medido em dois ramos de plantas adultas de lima ácida 'Tahiti', em relação ao comportamento da radiação líquida (Rn). Fazenda Areão, ESALQ/USP.

\subsubsection{Avaliação do desempenho do método de dissipação térmica por comparação com as medidas lisimétricas}

O uso do método de dissipação térmica resultou em valores diários de fluxo de seiva bastante concordantes com os dados de transpiração medidos pelos lisímetros (Figura 17 e Tabela 4).

Para corrigir a estimativa em função do gradiente térmico natural este foi medido concomitantemente com sensores não aquecidos, instalados em duas plantas de tamanho padrão do pomar (planta 9 e planta 10 da Fig. 5). 

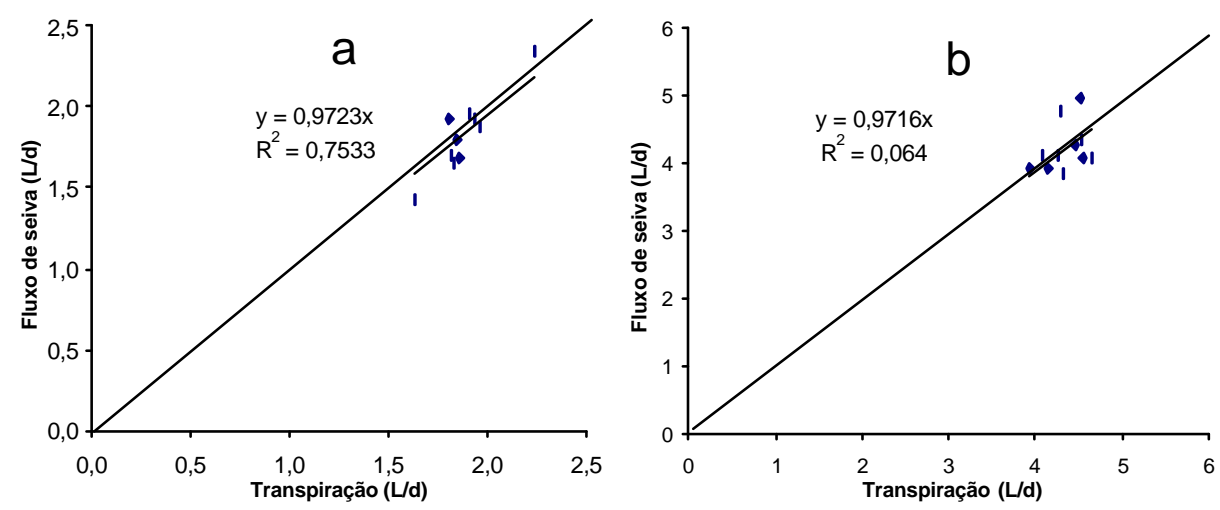

Figura 17 - Relação entre a transpiração diária, medida através de lisímetros, e o fluxo de seiva, medido pelo método de dissipação de calor de duas plantas jovens, com 1,78 (planta 7) e 3,12 $\mathrm{m}^{2}$ (planta 8) de área foliar, respectivamente, de 17 a 28 de agosto de 2002.

Como foi utilizado um único valor de gradiente térmico natural para ambas as plantas, provenientes de medidas realizadas em duas plantas fora dos lisímetros, foi verificada maior dispersão dos pontos de correlação correspondente à planta maior, devido, possivelmente, à diferença de tamanho entre ela e as que foram utilizadas para medir o gradiente (Fig. 17). Apesar desse fato, na Tabela 4 verifica-se que, após a correspondente correção, a diferença média das duas medidas foi da ordem de $3 \%$, confirmando observações de Cabibel \& Do (1991), com tendência de subestimativa do método de dissipação térmica.

Tabela 4. Medidas comparativas da transpiração diária de duas plantas medida através de lisímetros de pesagem (TR) e do fluxo de seiva (FS). Diferença relativa (DR) calculada em base na medida lisimétrica. $\mathrm{DR}=(\mathrm{FS} / \mathrm{TR}) / \mathrm{TR} * 100(\%)$.

\begin{tabular}{ccccccr}
\hline & \multicolumn{2}{c}{ TRANSPIRAÇÃO } & \multicolumn{2}{c}{ FLUXO DE SEIVA } & \multicolumn{2}{c}{ DIFERENÇA RELATIVA } \\
Data & Planta 7 & Planta 8 & Planta 7 & Planta 8 & Planta 7 & Planta 8 \\
\hline 18/Ago & 1,81 & 4,54 & 1,92 & 4,08 & 6,1 & $-10,1$ \\
19/Ago & 2,24 & 4,45 & 2,34 & 4,26 & 4,5 & $-4,3$ \\
20/Ago & 1,91 & 4,24 & 1,96 & 4,11 & 2,6 & $-3,1$ \\
21/Ago & 1,94 & 4,08 & 1,92 & 4,10 & $-1,0$ & 0,5 \\
22/Ago & 1,97 & 4,15 & 1,88 & 3,92 & $-4,6$ & $-5,5$ \\
23/Ago & 1,87 & 3,94 & 1,69 & 3,92 & $-9,6$ & $-0,5$ \\
24/Ago & 1,83 & 4,64 & 1,66 & 4,08 & $-9,3$ & $-12,1$ \\
25/Ago & 1,85 & 4,53 & 1,8 & 4,35 & $-2,7$ & $-4,0$ \\
26/Ago & 1,82 & 4,32 & 1,70 & 3,86 & $-6,6$ & $-10,6$ \\
27/Ago & 1,64 & 4,28 & 1,43 & 4,75 & $-12,8$ & 11,0 \\
28/Ago & & 4,51 & & 4,95 & & 9,8 \\
Média & $\mathbf{1 , 8 9}$ & $\mathbf{4 , 3 3}$ & $\mathbf{1 , 8 3}$ & $\mathbf{4 , 2 2}$ & $\mathbf{- 3 , 3}$ & $\mathbf{- 2 , 6}$ \\
\hline
\end{tabular}


Ao contrário do que tinha sido observado em plantas adultas (Fig.16), verificouse que em plantas jovens o gradiente térmico natural do tronco é muito mais acentuado no período diurno do que à noite. Em razão disso, o efeito desse gradiente é muito mais importante no período diurno. Na Figura 18 pode ser observado com maior detalhe o erro que pode representar esse efeito. Diante desse problema, a maneira de corrigi-lo é subtrair o gradiente térmico natural do valor registrado com a sonda aquecida. Observese que um dos sensores mede a diferença de temperatura não corrigida e o sensor não aquecido mede o gradiente térmico natural do tronco. Nota-se a grande diferença entre o fluxo de seiva corrigido e o não corrigido.
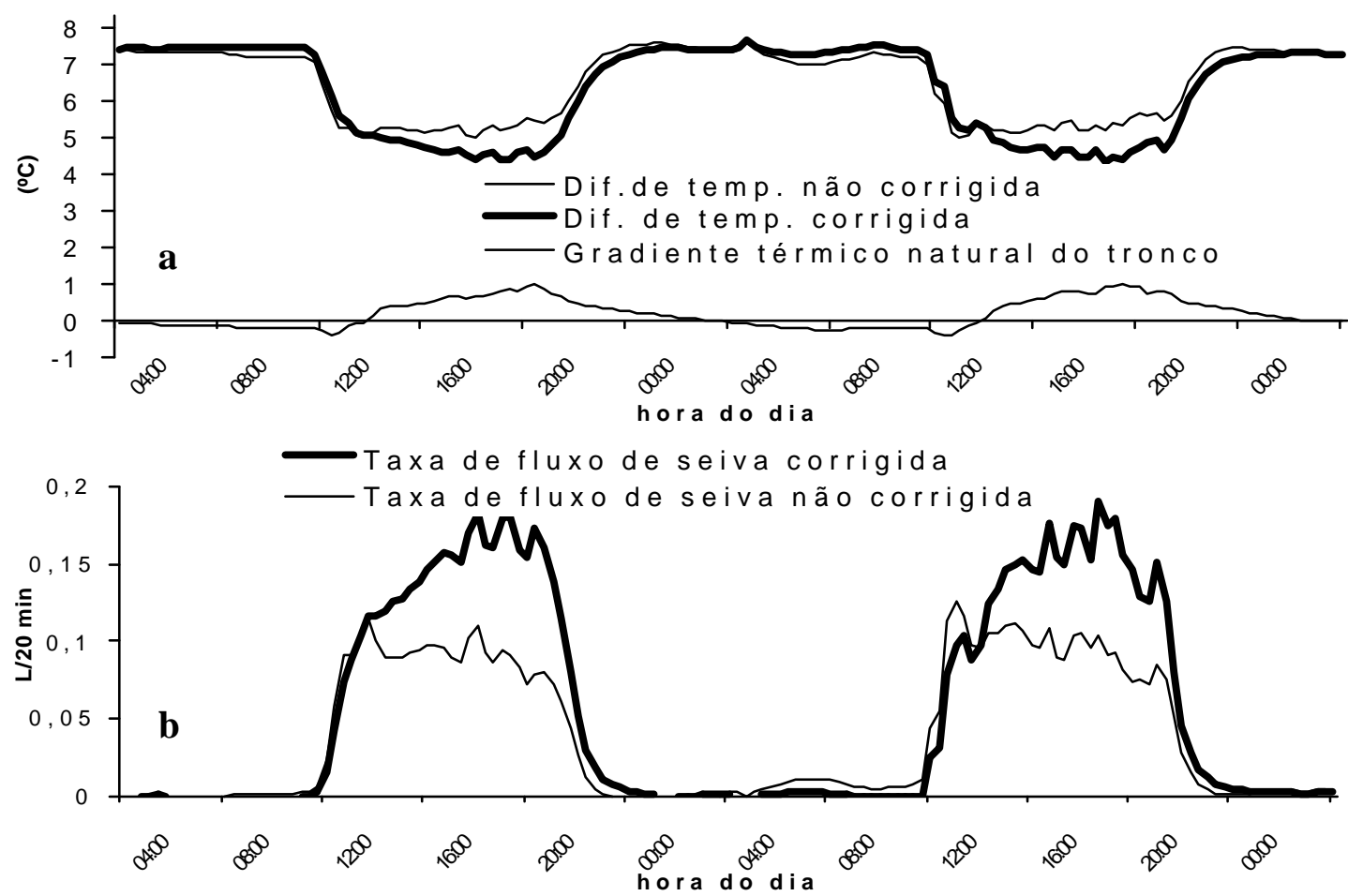

Figura 18 - a) Variação da diferença de temperatura do caule nas extremidades do segmento aquecido (Tc-Tb) considerando-se ou não o gradiente térmico natural mostrado. b) Variação da medida do fluxo de seiva em planta jovem com 3,12 $\mathrm{m}^{2}$ de área foliar, nos dias 21 e 22 de agosto de 2002. 
Na Figura 19 observa-se a evolução temporal das medidas de fluxo de seiva com relação à medida lisimétrica. Observa-se a defasagem entre o fluxo de seiva e a transpiração, principalmente na planta de maior tamanho, tal como foi observado por Granier (1985) e David et al. (1997).

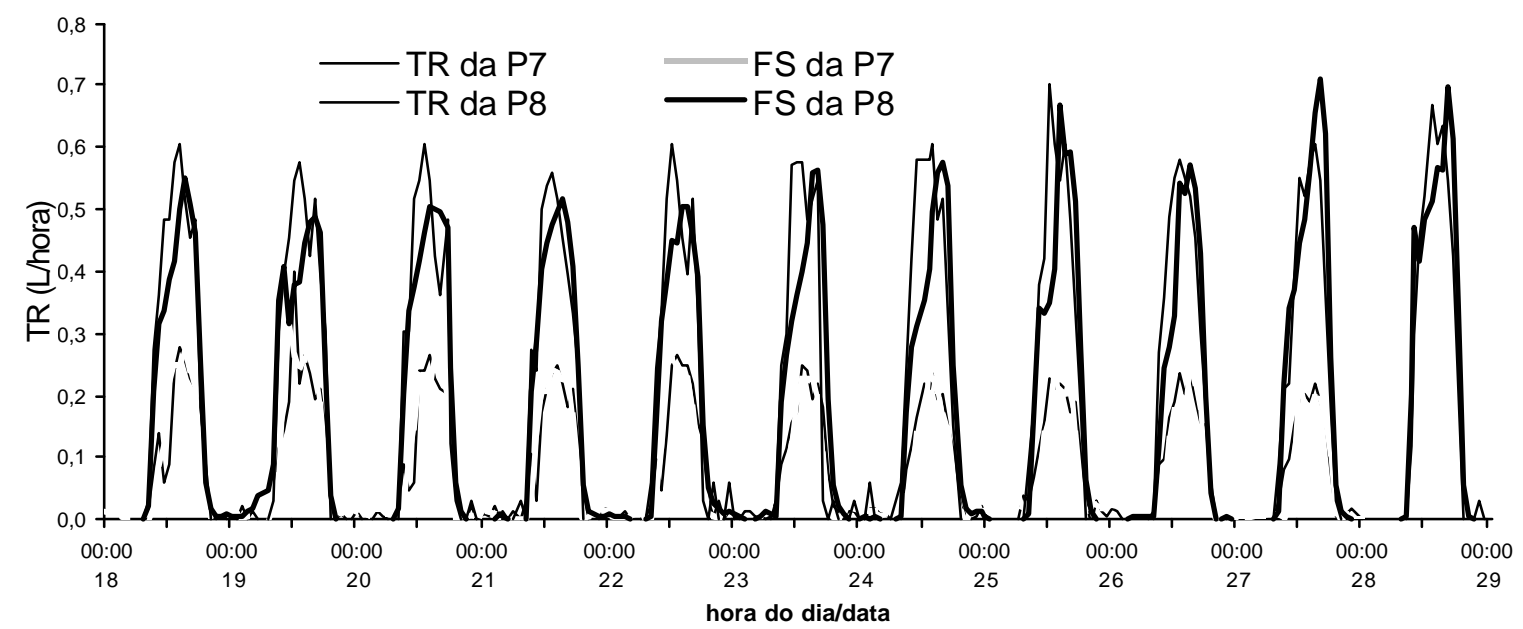

Figura 19 - Evolução temporal da taxa de transpiração (TR), medida através de dois lisímetros de pesagem, e do fluxo de seiva (FS), medido através do método de dissipação de calor em duas plantas jovens (P7 e P8) com 1,78 e 3,12 m² de área foliar, respectivamente, entre os dias 18 e 28 de agosto de 2002. Fazenda Areão, ESALQ/USP.

\subsubsection{Considerações sobre o uso de métodos de fornecimento de calor ao caule/ramo na determinação do fluxo de seiva em citros}

O uso dos métodos de fornecimento de calor ao caule/ramo ("métodos térmicos") para determinação de fluxo de seiva em plantas herbáceas e lenhosas ganhou grande impulso nas últimas duas décadas. Ao lado da técnica de pulso de calor, mais antiga, as técnicas de balanço de calor no caule e da sonda de dissipação de calor (ou "sonda de dissipação térmica") passaram a ser muito usadas na última década do século 20, principalmente em lenhosas. Em espécies cítricas elas tem sido pouco usadas, podendose citar os trabalhos realizados em Israel (Cohen et al.,1981, Cohen, 1991) com pulso de calor, e os realizados em Piracicaba, SP, por Trejo-Chandia et al. (1997), Coelho Filho (2002) e Marin et al. (2002), com o método de balanço de calor em lima ácida. 
Nos trabalhos de Trejo-Chandia et al. (1997) em casa de vegetação e de Coelho Filho (2002) no campo foram usadas plantas jovens (diâmetro de até 1,8 cm), tendo-se observado no primeiro deles uma superestimativa média de $13 \%$ da transpiração (fluxo e seiva) estimada pelo método em relação à medida por pesagem. No segundo trabalho, foi encontrada uma relação de 1:1 entre valores de fluxo de seiva e a transpiração (esta medida lisimetricamente), embora houvesse uma certa dispersão em torno da linha 1:1.

No trabalho de Marin et al (2002), as medidas foram realizadas em plantas adultas de grande porte, mas não se fez comparação com um método independente, pelas dificuldades decorrentes do tamanho das árvores. No presente estudo, as medidas comparativas com a sonda de dissipação térmica mostraram certos problemas com as duas técnicas discutidas nos itens 4.1.1 e 1.1.2, mas caso seja dada a atenção devida às fontes de erro discutidas, as duas técnicas podem fornecer resultados comparáveis, indicando que são confiáveis na determinação da transpiração diária de plantas adultas de citros, ainda que seja bastante recomendável outros estudos, envolvendo comparação não somente entre os dois métodos, mas também com um terceiro.

No caso de plantas jovens, considerando-se o observado neste trabalho com a comparação da sonda de dissipação de calor e da medida lisimétrica, pode-se considerar que esse método térmico também pode apresentar resultados confiáveis.

Portanto, ambas as técnicas mostram-se com grande potencial para determinação do consumo hídrico das plantas cítricas e de uso no nanejo da irrigação nos pomares dessas espécies. Além da necessidade de estudos adicionais, na escolha de uma das técnicas, devem-se comparar outros aspectos relativos às mesmas e discutir mais alguns pontos específicos.

No caso do método de balanço de calor, na prática foram observadas certas restrições. Uma delas é o período de tempo muito limitado que o sensor pode permanecer instalado no campo. Devido ao isolamento térmico do segmento envolvido, a água transpirada através da epiderme condensa e acumula-se naquele setor do caule sob o sensor. Isto pode afetar certas características físicas previamente estabelecidas, como a condutividade calorífica do fluxímetro e o calor específico do segmento, o que 
em conseqüência pode prejudicar a medida. Por outro lado, criam-se condições favoráveis para infestação e desenvolvimento de fungos e insetos, que podem danificar tanto o sensor como a própria planta, além de interferir na medida. Em período chuvoso, o tempo de permanência do sensor no campo diminui consideravelmente. Esta inconveniência pode limitar as análises dos dados, caso ela tenha que ser relacionada com medidas dentrométricas, por exemplo, já que para isso é desejável contar com dados contínuos por um período grande de tempo.

Outra limitação do método de balanço de calor deve-se ao fato de que o sensor deve ser bem ajustado em volta do tronco. Entretanto, em plantas cítricas adultas é praticamente impossível instalá-lo no tronco, pela irregularidade deste, havendo necessidade de uso de grande número de sensores por árvore, pois é necessário instalálos nos ramos primários selecionados. O tempo gasto na confecção e o tedioso trabalho que ela representa, deve ser levado em consideração, caso se queira construí-los sendo a alternativa adquiri-los no comércio a custo elevado. Uma outra restrição observada é o grande número de medidas exigidas na técnica, o que complica a aquisição automática dos dados. No caso deste trabalho, apesar de ter sido utilizado um sistema de aquisição de dados com elevada capacidade (CR7 com 52 canais), apenas foi possível instalar 8 sensores simultaneamente, permitindo o envolvimento de apenas duas plantas.

Quanto ao método de dissipação térmica, a facilidade de confecção e instalação do sensor supera de longe os outros dois métodos térmicos de medida de fluxo de seiva. Além disso, o tempo de permanência no campo somente pode ser limitado pela falta de resistência do sensor à temperatura e umidade as quais está submetido permanentemente, fato que foi observado durante o experimento com alguns sensores. Por outro lado, ele ocupa apenas um canal no sistema de aquisição de dados, o que já seria uma razão muito grande para se trabalhar preferentemente com este método.

Loustau et al. (1998) num estudo realizado com pinheiro, ao medirem o fluxo de seiva com sensores de Granier distribuídos simetricamente em volta do tronco, em quatro orientações e em duas alturas, a 1,5 e 8,5 m do solo, constataram notáveis diferenças nas medidas entre cada orientação, principalmente a 1,5 m. Os autores 
atribuíram este fato à distribuição desuniforme do fluxo de seiva através do corte transversal do xilema. Eles não consideraram a interferência do gradiente térmico natural na suas medidas. Ferreira (1996b), trabalhando com pessegueiro, observou que o método de balanço de calor mostrou valores $61 \%$ superior ao de dissipação de calor, diferença que pode ser atribuída ao gradiente térmico do talo. Após todas as observações no campo, há razão suficiente para se afirmar que o gradiente térmico natural deve ser considerado indefectivelmente e, se possível, deve ser considerada a orientação azimutal do sensor. De qualquer maneira, um estudo mais aprofundado deve ser realizado para tentar encontrar uma solução ao problema da existência do gradiente térmico natural e se possível, criar uma padronização da orientação do sensor para a latitude do local.

No caso dos experimentos deste estudo, demonstrou-se que o método da sonda de dissipação térmica é suficientemente sensível para detectar mudanças na condição hídrica da planta e responder à variação de área foliar. Comparando com o método de balanço de calor, ele pode ser considerado uma melhor alternativa, tanto para determinação do consumo hídrico, como para se ter um indicador vegetal do déficit hídrico, como, por exemplo, na forma de uma transpiração relativa, como discutido a seguir.

\subsection{Transpiração relativa e variação radial do caule/ramo como indicadores das condições hídricas das plantas cítricas}

O objetivo desta secção é apresentar os resultados e discutir o uso da transpiração relativa e da variação radial do caule como indicadores das condições hídricas da planta, verificando a possibilidade de usá-los na determinação do momento exigido para a irrigação em espécies cítricas.

O assunto é introduzido com a apresentação e discussão dos resultados referentes aos testes preliminares de desempenho dos dendrômetros de precisão, seguindo-se a apresentação de resultados e a discussão sobre o uso da transpiração relativa e das 
variações micrométricas do diâmetro do caule e de ramos como indicadores das condições hídricas de plantas de lima ácida.

\subsubsection{Análise preliminar do desempenho do dendrômetro de precisão}

A figura 20 mostra a variação micrométrica do diâmetro do ramo de uma planta adulta entre 21 de março $(\mathrm{DJ}=80)$ e 15 de maio $(\mathrm{DJ}=135)$ de 2000 (ver calendário juliano no Anexo 1), junto com os valores de altura pluviométrica diária. Observa-se a grande sensibilidade do dendrômetro, cuja resposta reflete às variações do diâmetro do ramo de forma coerente, com aumento do diâmetro em períodos de chuva e sua diminuição em períodos secos.

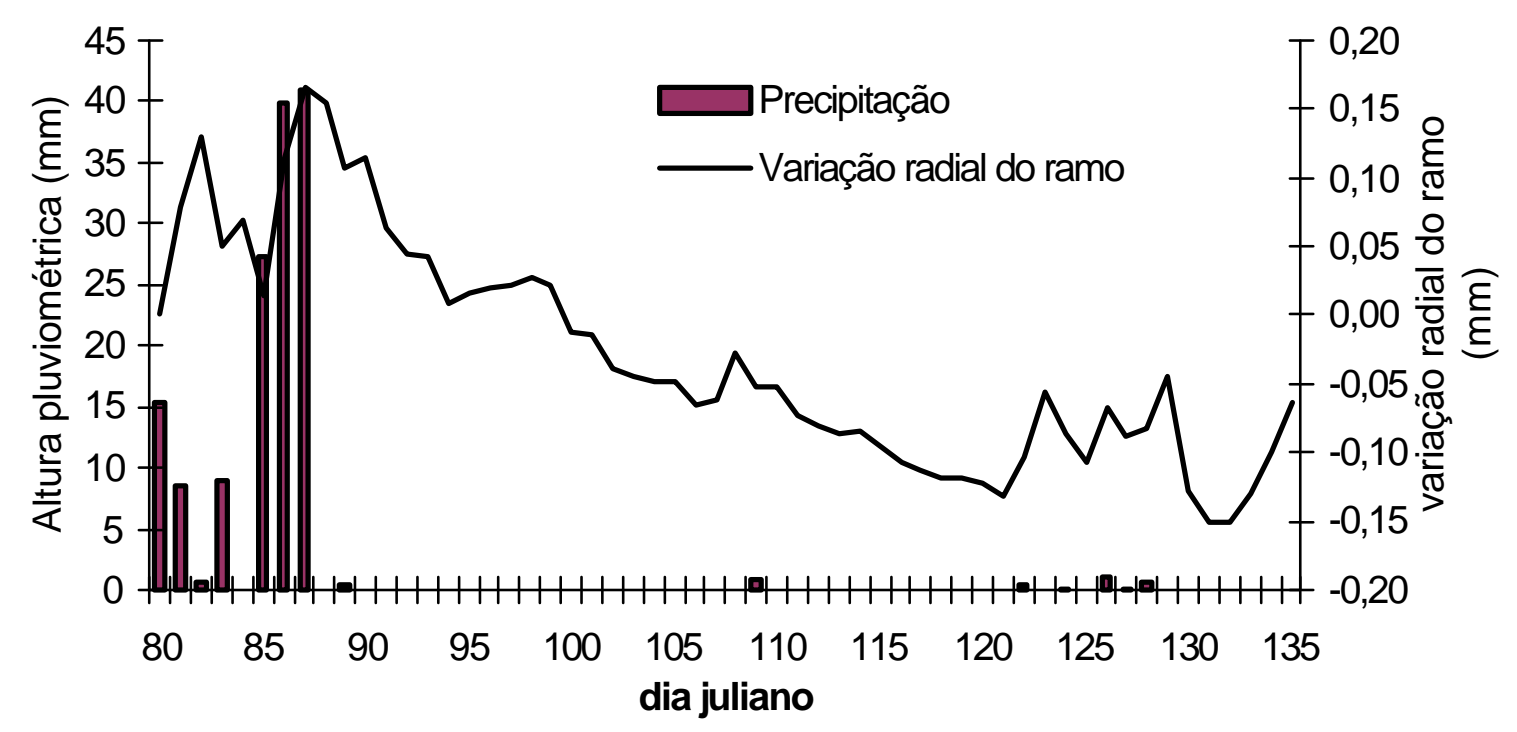

Figura 20 - Evolução da variação radial do diâmetro de ramo de lima ácida 'Tahiti' em resposta às chuvas registradas entre o 21 de março $(D J=80)$ e 15 de maio $(\mathrm{DJ}=135)$ de 2000. Fazenda Areão, ESALQ-USP.

O dendrômetro, também, demonstrou resposta coerente quando se analisa a variação radial em resposta a vários elementos meteorológicos que afetam a transpiração e, consequentemente, o balanço hídrico da planta. As figuras 21 e 22 mostram a evolução ao longo de vários dias, da variação radial do ramo, da irradiância solar global, da temperatura e da umidade relativa do ar. Como essas variáveis afetam a evapotranspiração e, consequentemente, o balanço hídrico do solo e da planta, observa- 
se uma boa relação entre elas e a variação radial. O máximo de distensão ocorre pouco antes do sol nascer, quando a reidratação máxima dos tecidos é atingida. A contração máxima ocorre no meio da tarde, simultaneamente à ocorrência da umidade relativa mínima e da máxima temperatura do ar. Portanto, a amplitude de variação depende, diariamente, dessas variáveis meteorológicas, além da velocidade do vento e da disponibilidade hídrica do solo.

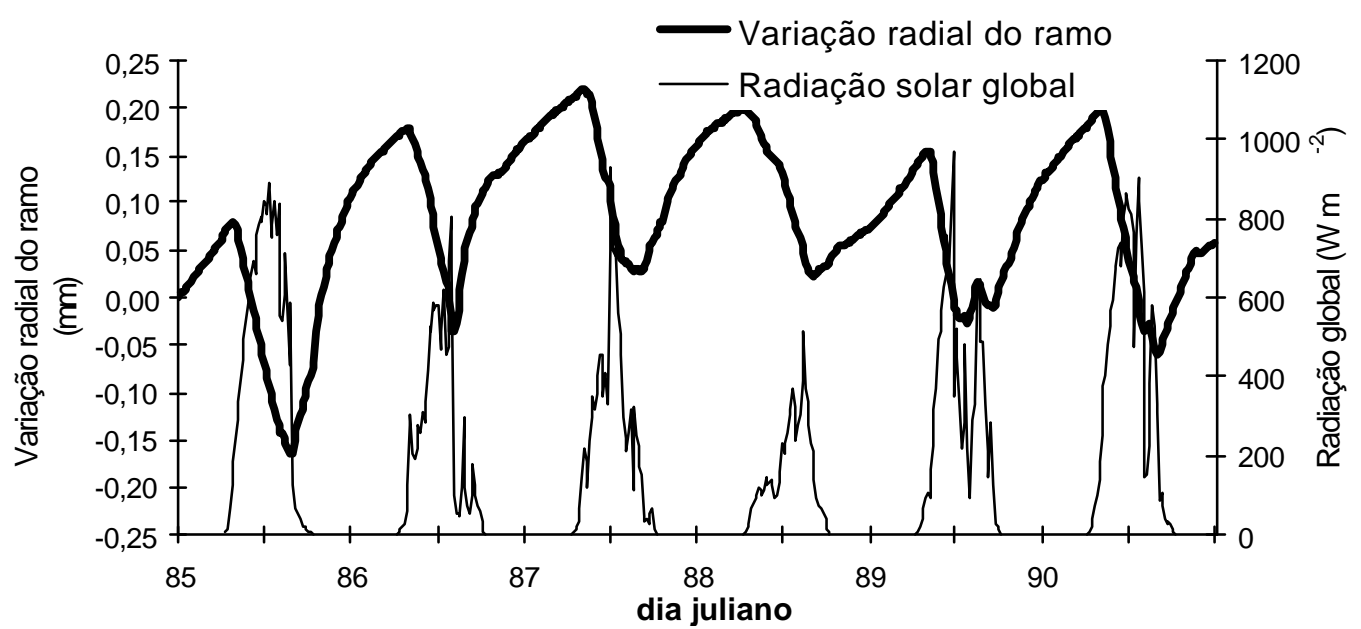

Figura 21 - Variação radial do diâmetro do ramo de lima ácida 'Tahiti' em resposta à taxa da radiação solar global. Registrado entre 26 e 31 de março (DJ=8590) de 2000 (dados médios de intervalos de 15 minutos). Fazenda Areão, ESALQ/USP.

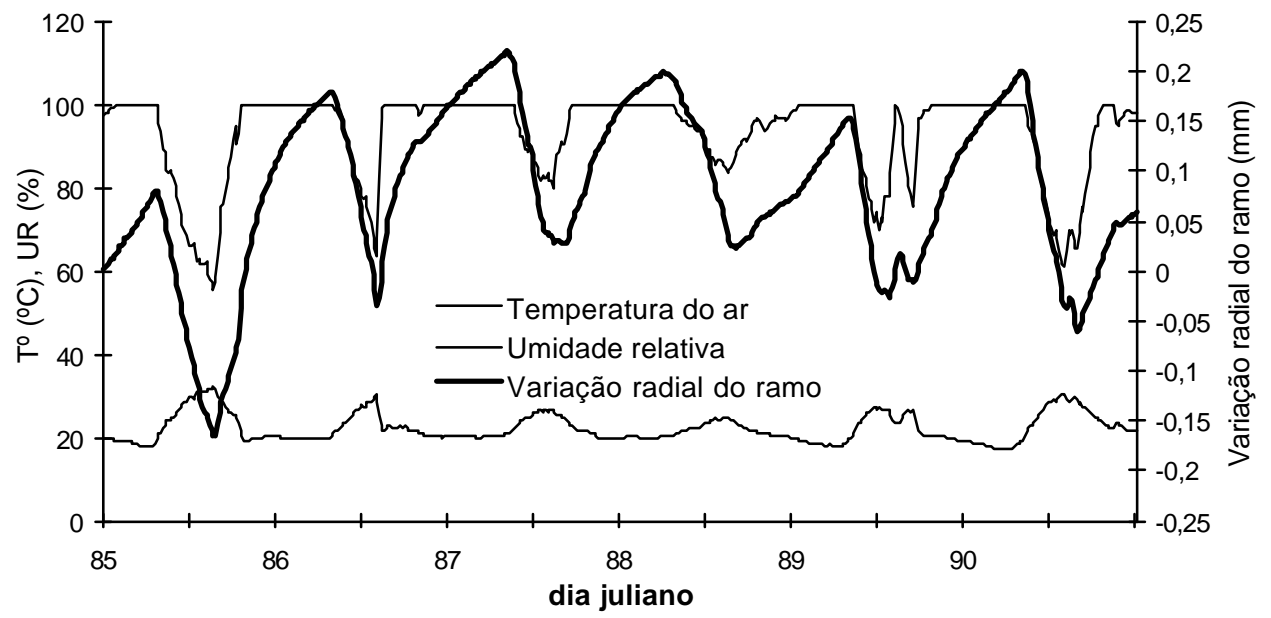

Figura 22 - Variação radial do diâmetro do ramo de lima ácida 'Tahiti' em resposta à temperatura $\left({ }^{\circ} \mathrm{C}\right)$ e umidade relativa do ar $(\%)$. Fazenda Areão. ESALQ/USP, 26 a 31 de março (DJ=85-90) de 2000 (dados médios de intervalos de 15 minutos). 
Um fato observado é a proporcionalidade entre a amplitude de contração radial do ramo e o seu diâmetro. Na Figura 23 pode-se verificar que a evolução dessa contração é muito mais marcante no ramo com $6,5 \mathrm{~cm}$ de diâmetro que no de $3,4 \mathrm{~cm}$. Este fato, segundo Ginestar \& Castel (1998), pode ser esperado devido ao ramo maior ter mais capacidade de armazenamento de água. Isto não significa que o ramo maior seja mais sensível que o menor, mas simplesmente que a leitura dada pelo dendrômetro depende do tamanho do órgão da planta.

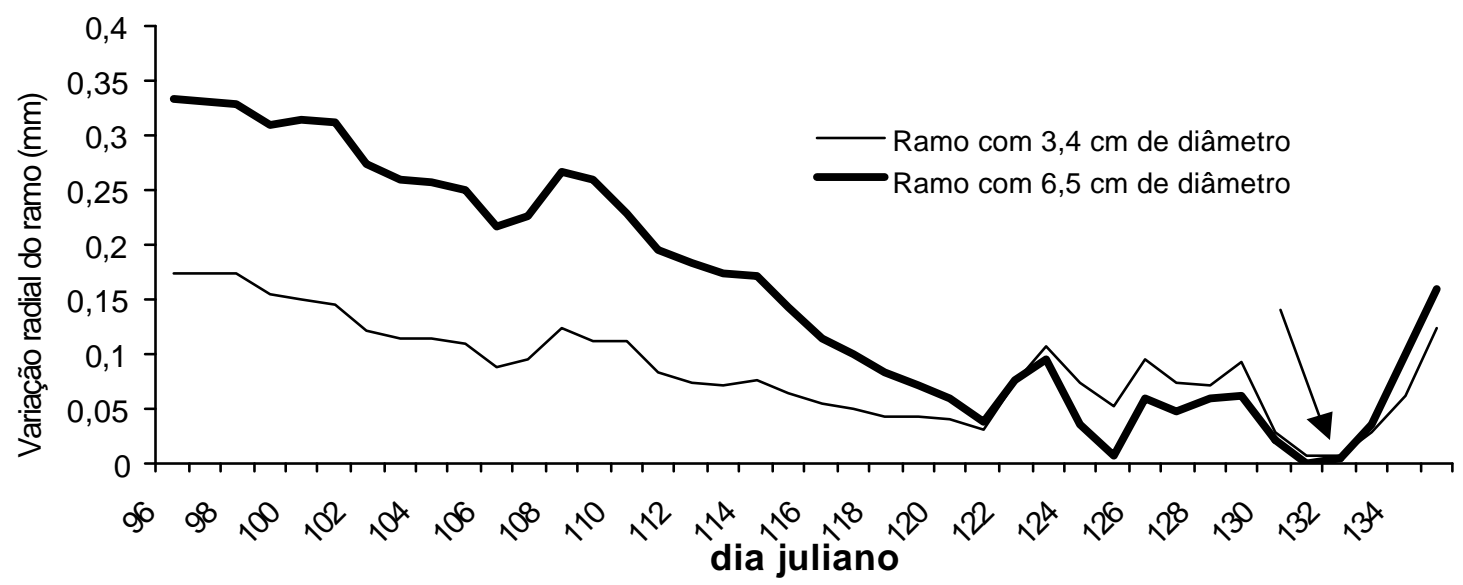

Figura 23 - Evolução da variação média diária do diâmetro de dois ramos de diâmetros diferentes $(3,4$ e $6,5 \mathrm{~cm})$ entre os dias 6 de abril (DJ=98) e 15 de maio $(\mathrm{DJ}=135)$ de 2000.

Neste exemplo observa-se uma evolução decrescente até um ponto em que a condição hídrica volta a ser favorável para a planta. A seta indica uma irrigação abundante naquela data; a partir deste ponto, a taxa de crescimento do diâmetro do ramo maior supera à do ramo menor, tendendo a atingir o seu diâmetro original.

Na Figura 24 está resumida a tendência dos parâmetros dendrométricos, amplitude diária de contração (ADC), evolução do diâmetro máximo (DMax) e evolução do diâmetro médio (ED), em resposta ao estresse hídrico gradual sofrido pela planta. Observa-se que, após as chuvas registradas no começo desse período, a ED se manteve com uma tendência decrescente, indicando uma contração gradual a medida que aumenta a estiagem. Somente no dia 13 de maio (DJ= 133), após uma forte irrigação, o ramo começou a aumentar de diâmetro, demonstrando uma reação forte da 
planta à nova condição hídrica do solo. Goldhamer et al (1999) trabalhando com pessegueiro e Moriana et al. (2000) com oliveira, observaram que quando a planta volta a ter sua condição hídrica ideal o órgão tende a atingir seu tamanho original (anterior ao déficit); mas, sempre fica menor do que aquele que não sofreu estresse hídrico.
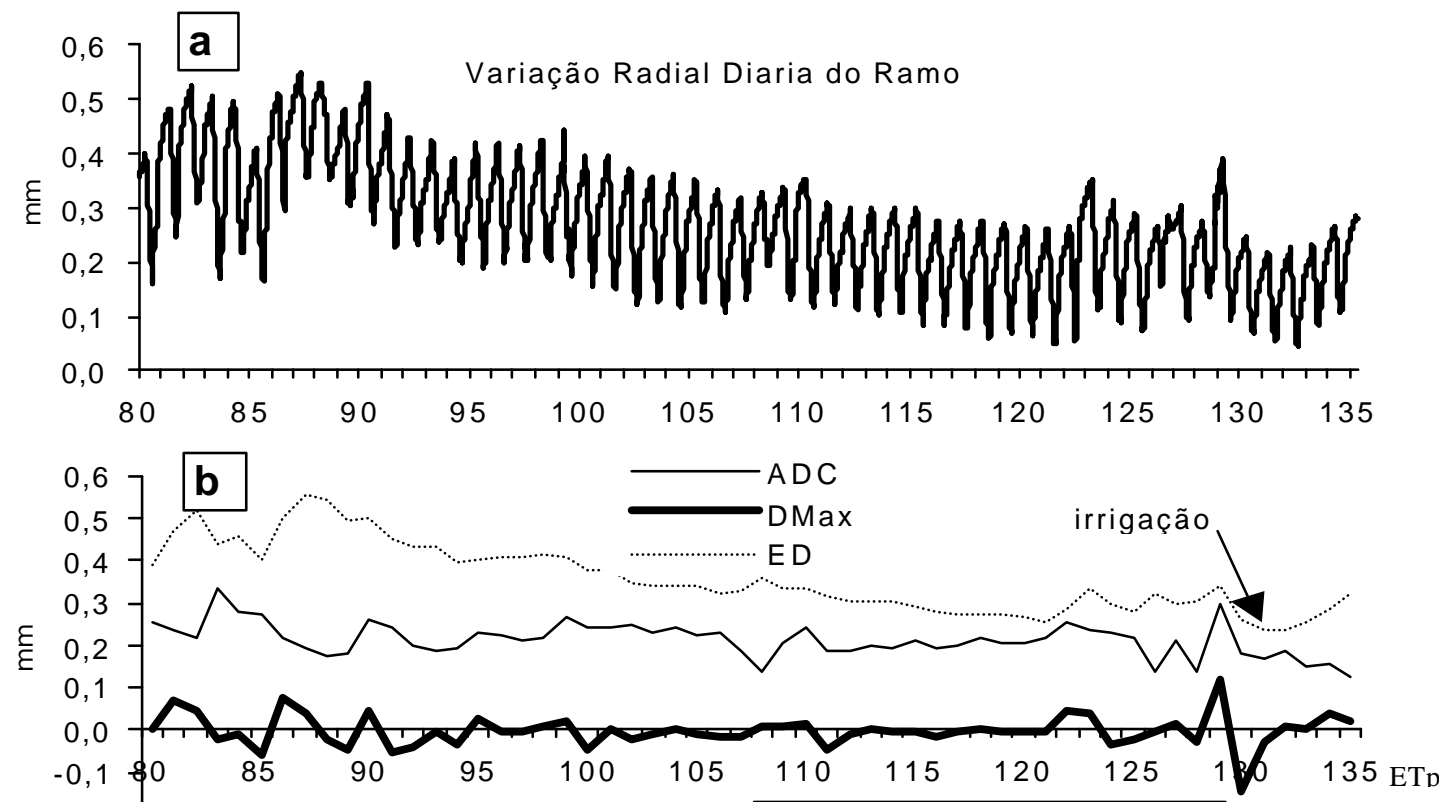

$-0,2$ dias com baixa demanda
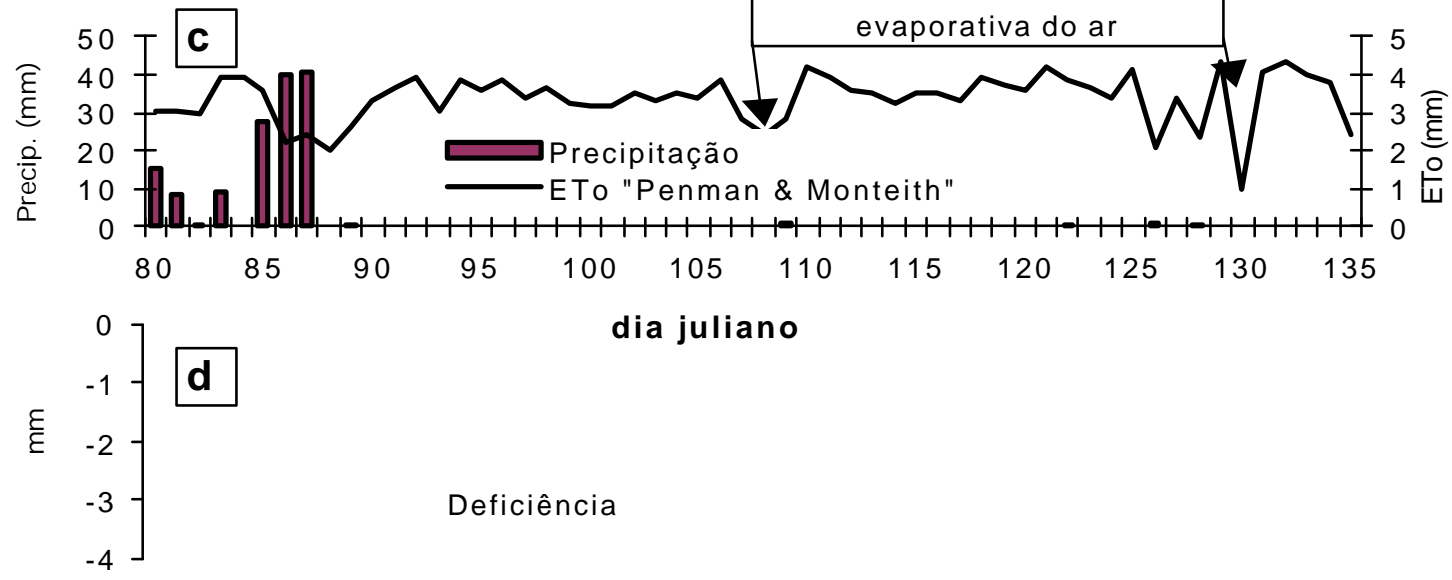

dia juliano

Figura 24 - Evolução dos parâmetros dendrométricos do ramo de uma planta adulta ao longo de um período de 56 dias, de 21 de março a 15 de maio (DJ= 80-135) de 2000; a) evolução do diâmetro de um ramo; b) evolução do diâmetro médio (ED), amplitude diária de contração (ADC) e evolução do diâmetro máximo (DMax), c) evapotranspiração potencial (ETo) e precipitação; d) deficiência hídrica no solo (baseada no balanço hídrico). 
Todas as observações mostraram que o dendrômetro é suficientemente sensível para registrar variações micrométricas do diâmetro do ramo em resposta às variações da condição hídrica e microclimática da planta. A avaliação da sensibilidade dos parâmetros mais utilizados, ADC, DMax e DMin, com relação a essas mudanças, serão tratados nos seguintes itens.

\subsubsection{Transpiração relativa e variação radial dos caules e de ramos}

\subsubsection{Cálculo da transpiração relativa}

A transpiração relativa foi calculada pela relação entre a transpiração diária (fluxo de seiva) da planta amostrada e a da planta sob condições hídricas ideais no solo, para a qual assumiu-se a transpiração máxima ou potencial. Como as plantas tinham áreas foliares diferentes, a transpiração foi calculada como densidade de fluxo por unidade de área foliar.

No cálculo de fluxo de seiva pelo método de Granier (dissipação térmica), no qual a área efetiva para o fluxo foi considerada, após testes com corante, como sendo a área da secção reta do caule ou ramo, descontada a área da casca, foram feitas medidas a intervalos de tempo (Tabela 5), sendo ajustadas equações em função do tempo (Figura 25), usada então para cada dia de estudo.

Tabela 5. Diâmetro do tronco (D) e área efetiva de condução de seiva (AE) de 6 plantas.

\begin{tabular}{cccccccccccccccc}
\hline DATA & \multicolumn{2}{c}{ Planta 1 } & \multicolumn{3}{c}{ Planta 2 } & \multicolumn{3}{c}{ Planta 3 } & \multicolumn{3}{c}{ Planta 4 } & \multicolumn{3}{c}{ Planta 5 } & \multicolumn{3}{c}{ Planta 6 } \\
Dia & D & AE & D & AE & D & AE & D & AE & D & AE & D & AE \\
juliano & $\mathrm{cm}$ & $\mathrm{m}^{2}$ & $\mathrm{~cm}$ & $\mathrm{~m}^{2}$ & $\mathrm{~cm}$ & $\mathrm{~m}^{2}$ & $\mathrm{~cm}$ & $\mathrm{~m}^{2}$ & $\mathrm{~cm}$ & $\mathrm{~m}^{2}$ & $\mathrm{~cm}$ & $\mathrm{~m}^{2}$ \\
\hline $\mathbf{1 9 4}$ & 5,04 & 0,002000 & 4,8 & 0,001809 & 4,91 & 0,001893 & 3,6 & 0,001020 & 3,67 & 0,001060 & 3,2 & 0,000810 \\
$\mathbf{2 3 1}$ & 5,15 & 0,002084 & 5 & 0,001963 & 5,08 & 0,002027 & 3,72 & 0,001090 & 3,8 & 0,001130 & 3,4 & 0,000910 \\
$\mathbf{2 6 6}$ & 5,45 & 0,002330 & 5,25 & 0,002165 & 5,28 & 0,002190 & 4,05 & 0,001290 & 4,18 & 0,001370 & 3,8 & 0,001130 \\
$\mathbf{3 3 3}$ & 6,21 & 0,003020 & 5,89 & 0,002725 & 6,04 & 0,002865 & 4,77 & 0,001787 & 5,16 & 0,002090 & 5,09 & 0,002030 \\
\hline
\end{tabular}



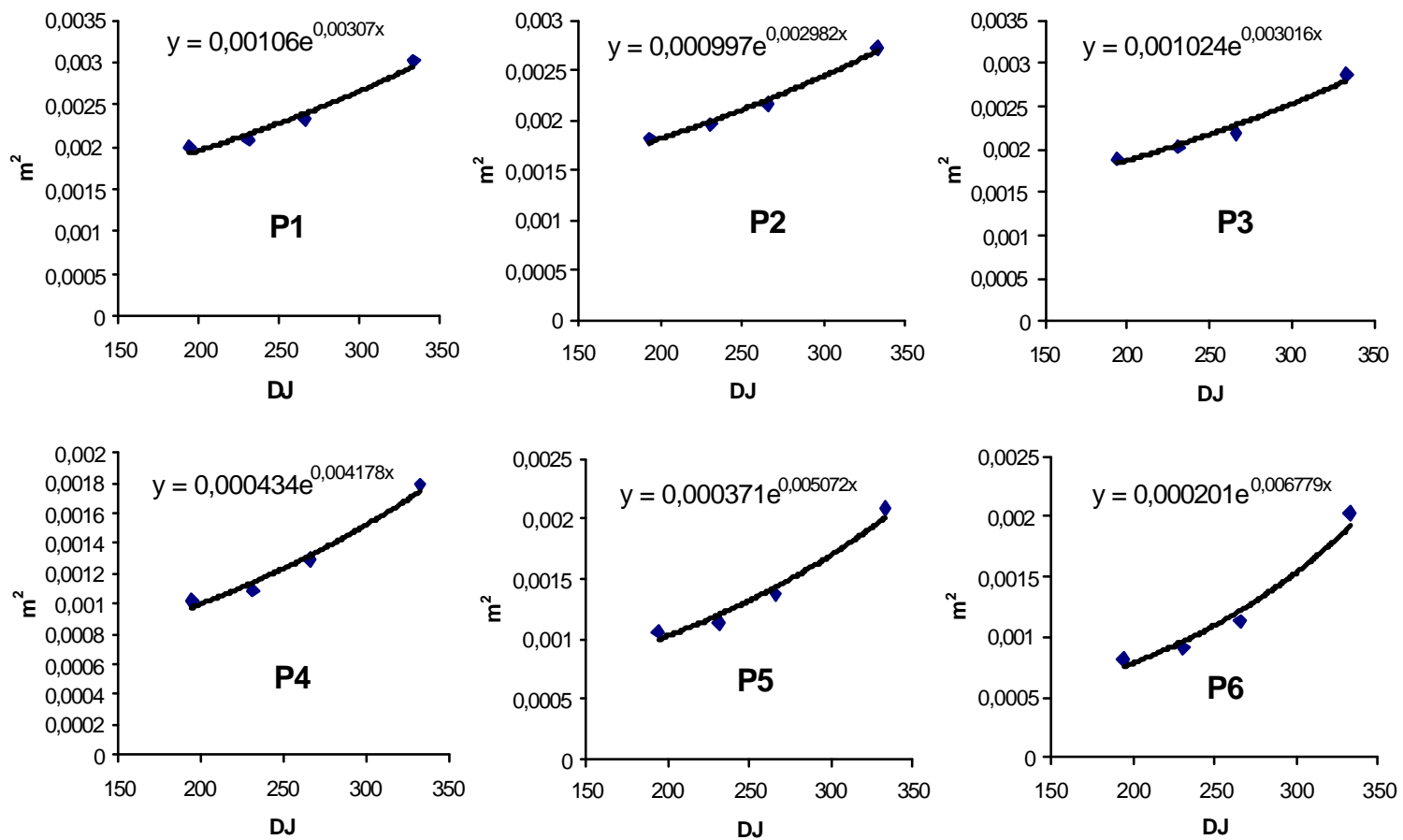

Figura 25 - Relação entre a área efetiva de condução da seiva $\left(\mathrm{m}^{2}\right)$ e a data, expressa em dias juliano (DJ).

A área foliar, para cada data específica foi estimada com base na equação de sua variação com o tempo, obtidos a partir das medidas da área em vários dias. Os valores usados na determinação dessas relações estão m Tabela 6. A Figura 26 mostra a relação e respectiva equação de ajuste para cada planta.

Tabela 6. Área foliar, em $\mathrm{m}^{2}$, de 7 plantas medidas entre julho e novembro de 2002.

\begin{tabular}{ccccccc}
\hline \multirow{2}{*}{$\begin{array}{c}\text { DATA } \\
\text { Dia juliano }\end{array}$} & Planta 1 & Planta 2 & Planta 3 & Planta 4 & Planta 5 & Planta 6 \\
\hline $\mathbf{1 9 4}$ & 4,1 & 4,11 & 4,18 & 1,5 & 4,2 & 1,92 \\
$\mathbf{2 3 1}$ & 4,37 & 4,28 & 4,41 & 1,58 & 4,29 & 2,2 \\
$\mathbf{2 6 6}$ & 6,2 & 5,48 & 5,67 & 2 & 5,31 & 3,8 \\
$\mathbf{3 3 3}$ & 12,8 & 11,7 & 9,8 & 3,82 & 8,48 & 8,56 \\
\hline
\end{tabular}



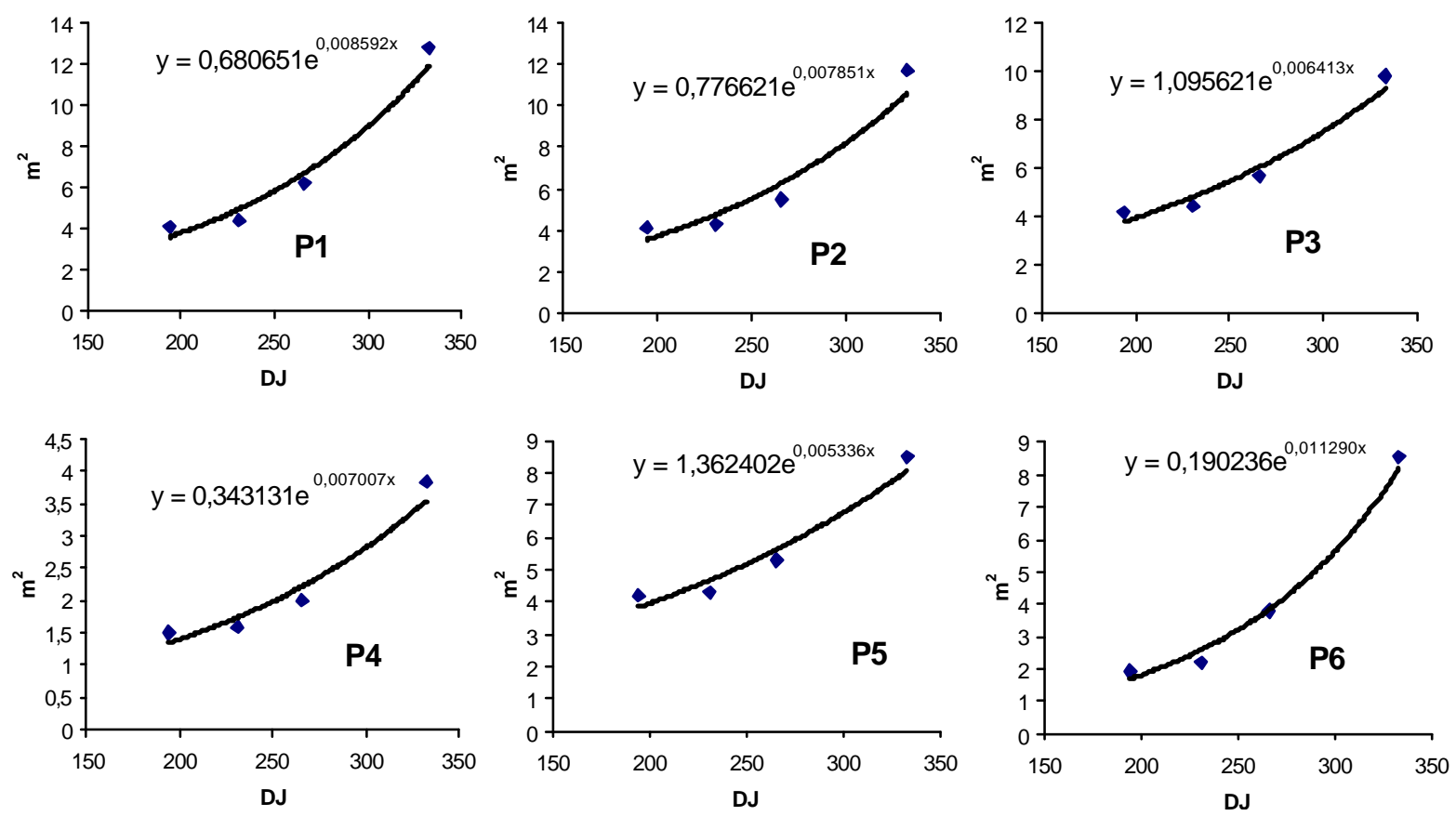

Figura 26 - Relação entre a área foliar da planta $\left(\mathrm{m}^{2}\right)$ e a data, expresso em dia juliano (DJ).

Como as plantas foram submetidas a diferentes regimes de irrigação, a taxa de crescimento da área foliar de cada uma delas foi diferente. A planta 1, por exemplo, que foi mantida sem irrigação e, posteriormente, com irrigação adequada, no final do experimento teve o maior crescimento. A planta 4, que estava com isolamento do sistema radicular na parte superior e lateral do solo, provavelmente devido a esse confinamento e estresse hídrico mais freqüente, apresentou menor crescimento de área foliar no dia do ano 333, cerca de 3 vezes menor que o da planta 1.

\subsubsection{Variação do potencial mátrico da água do solo}

As figuras 27, 28 e 29 mostram a variação do potencial mátrico da água do solo ao longo dos experimentos no pomar adulto e no jovem, nas plantas usadas nas medidas de fluxo de seiva e de dendrometria em 2002. São indicadas nas figuras as variações para as quatro profundidades de medida $(0,10 ; 0,20 ; 0,30$ e $0,50 \mathrm{~m})$, para uma melhor 
análise da água disponível no perfil de solo. No caso da planta adulta, são indicados, também, os valores de volume de irrigação da planta 1, assim como a altura pluviométrica ocorrida. Os valores do volume de água utilizados na irrigação de cada planta jovem, assim como a precipitação pluviométrica registrada nesse período (setas, das figuras 28 e 29) estão no Anexo 10. Os demais dados meteorológicos podem ser encontrados nos Anexos 2 a 5

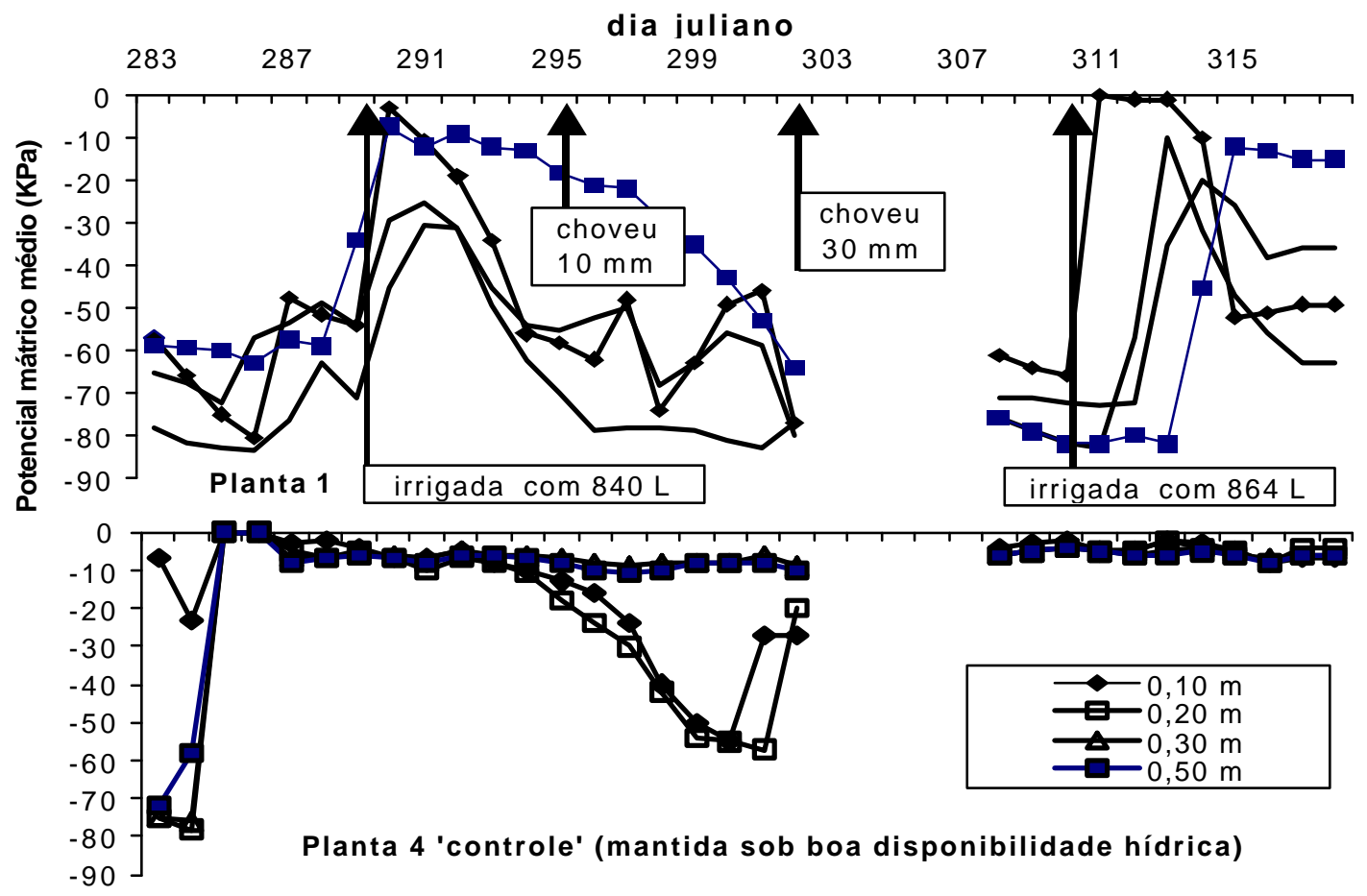

Figura 27 - Variação temporal do potencial mátrico da água do solo no pomar adulto, no ano de 2002. Os valores representam médios de quatro medidas em cada profundidade. As setas com rótulos indicam dias e quantidade de irrigação e dias de ocorrência de chuva.

Observa-se no experimento do pomar adulto que a planta 4, usada como controle (irrigada frequientemente), apresentou altos valores de potencial mátrico ao longo do período analisado, sendo que somente em torno do dia 300 as duas menores profundidades $(0,10 \mathrm{~m}$ e $0,20 \mathrm{~m})$ apresentaram valores mínimos em torno de $-55 \mathrm{kPa}$; pode-se portanto, considerar que ela teve condições ideais de água no solo em praticamente todo o período mostrado. Por outro lado, a planta 1 não foi irrigada em parte do período entre os dias juliano 298 e 302, antes de acontecer uma chuva de 30 
mm, ficou submetida a grau acentuado de déficit hídrico no solo, na mesma condição da que no período 284 e 287, antes de ser irrigada com 840 L. É interessante observar que nesse período intermediário, entre as datas mencionadas, de 287 a 298 (11 dias), a água aplicada através da irrigação no dia 289 além dos $10 \mathrm{~mm}$ de chuva registrada no dia 295 foi consumida totalmente, conforme demonstra os valores do potencial mátrico, que atingiram novamente valores críticos de umidade. Os $30 \mathrm{~mm}$ de chuva registrados no dia juliano 302 fizeram aumentar novamente a umidade no solo. Entre os dias 302 e 307, após da ocorrência da chuva, não foram realizadas leituras dos tensiômetros mas, podese supor que houve um significativo aumento do potencial mátrico que, logo após, foi diminuindo gradativamente até atingir valores críticos entre os dias 308 e 310 . Neste dia, a planta 1 foi irrigada com 864 L, recuperando-se do déficit hídrico nos dias posteriores.

No pomar jovem, a planta 1 apresentou entre os dias 236 e 243 uma secagem em todo o perfil de solo até $50 \mathrm{~cm}$, que se acentuou do dia 226 até o dia 243, a partir de quando as irrigações e chuvas permitiram que o solo se mantivesse com boa disponibilidade hídrica até o final do experimento. Valores de potencial mátrico relativamente baixos ocorreram até a profundidade de $0,5 \mathrm{~m}$ entre os dias 257 e 259 e entre as profundidades de 0,30 a 0,50 m entre os dias 307 e 309, e entre os dias 314 e 317, que poderiam ter induzido pequeno déficit hídrico na planta, mas em geral pode-se considerar que essa planta manteve-se em condições de boa disponibilidade hídrica praticamente em todo o período a partir do dia 250. Por esse motivo, ela foi adotada como a planta controle a partir do dia 261.

As 5 outras plantas desse pomar que foram utilizadas ficaram submetidas a regimes de água no solo ligeiramente diferentes, sendo que as de número 4 e 5 referemse aquelas cuja superfície e laterais do solo até $0,60 \mathrm{~m}$ de profundidade de solo permaneceram cobertas com plástico evitando-se a entrada de água de chuva. 

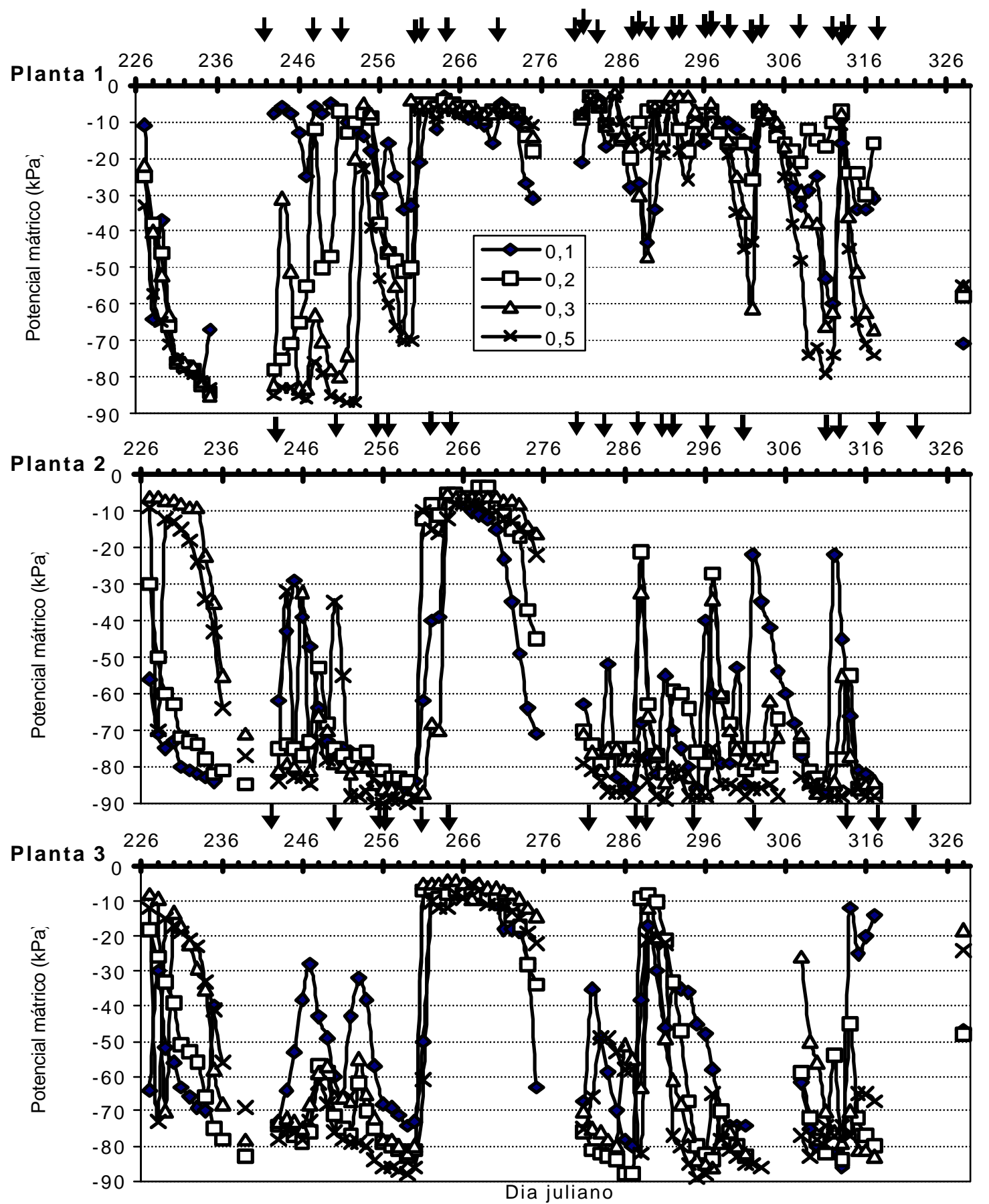

Figura 28 - Variação temporal do potencial mátrico da água em 4 profundidades (legenda, em m) no solo nas plantas 1, 2 e 3 do pomar jovem usadas nas determinações de fluxo de seiva e dendrométricas. As setas indicam irrigação e/ou chuva, cujos valores se encontram no Anexo 10. 

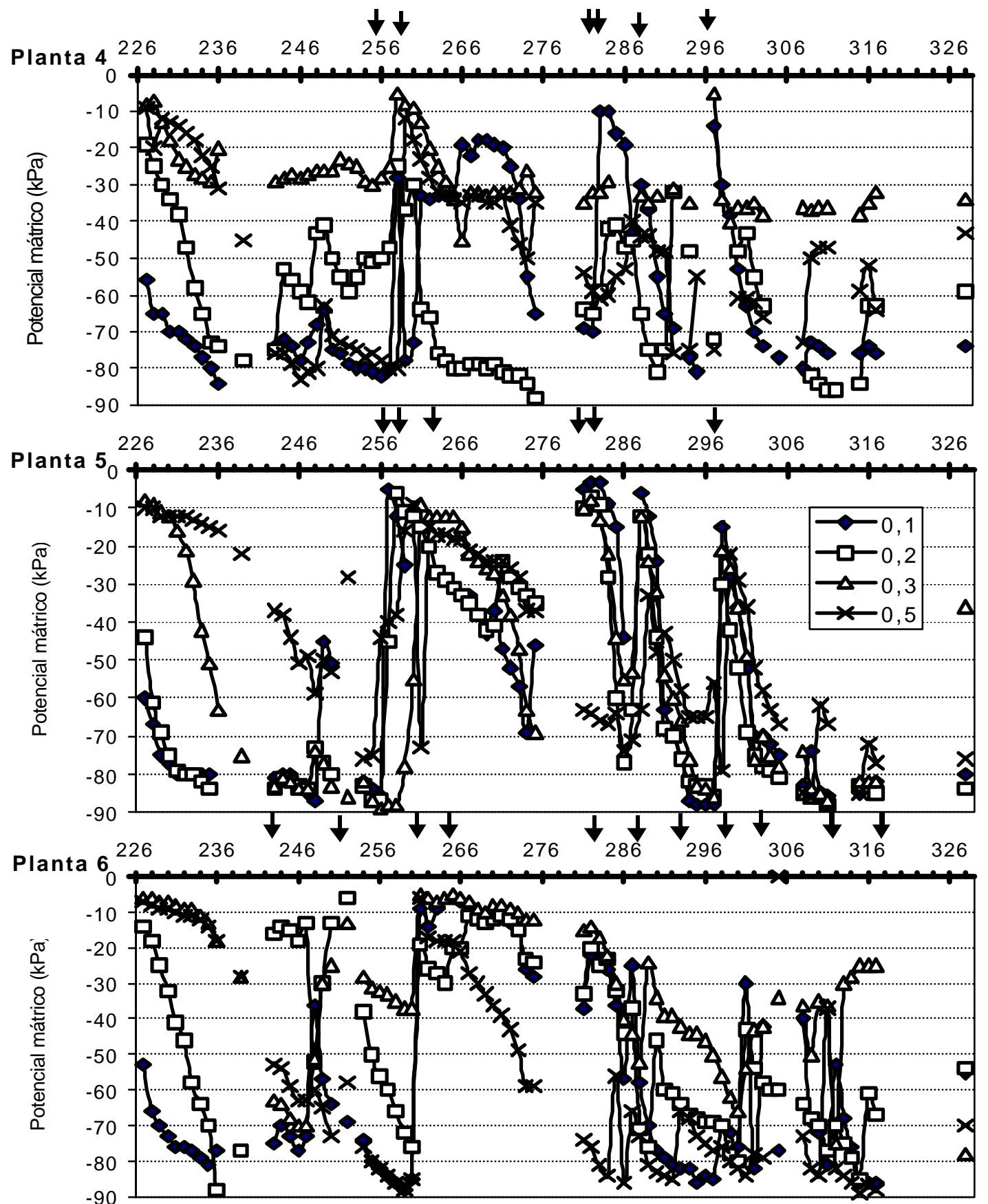

Dia juliano

Figura 29 - Variação temporal do potencial mátrico da água em 4 profundiades (legenda, em m) no solo nas plantas 4, 5 e 6 do pomar jovem usadas nas determinações de fluxo de seiva e dendrométricas. As setas indicam irrigação e/ou chuva, cujos valores se encontram no Anexo 10. 


\subsubsection{Relação entre a amplitude diária de contração e a transpiração relativa das plantas jovens.}

A Figura 30 mostra a relação entre a amplitude diária de contração e a transpiração relativa diária para as plantas jovens utilizadas.

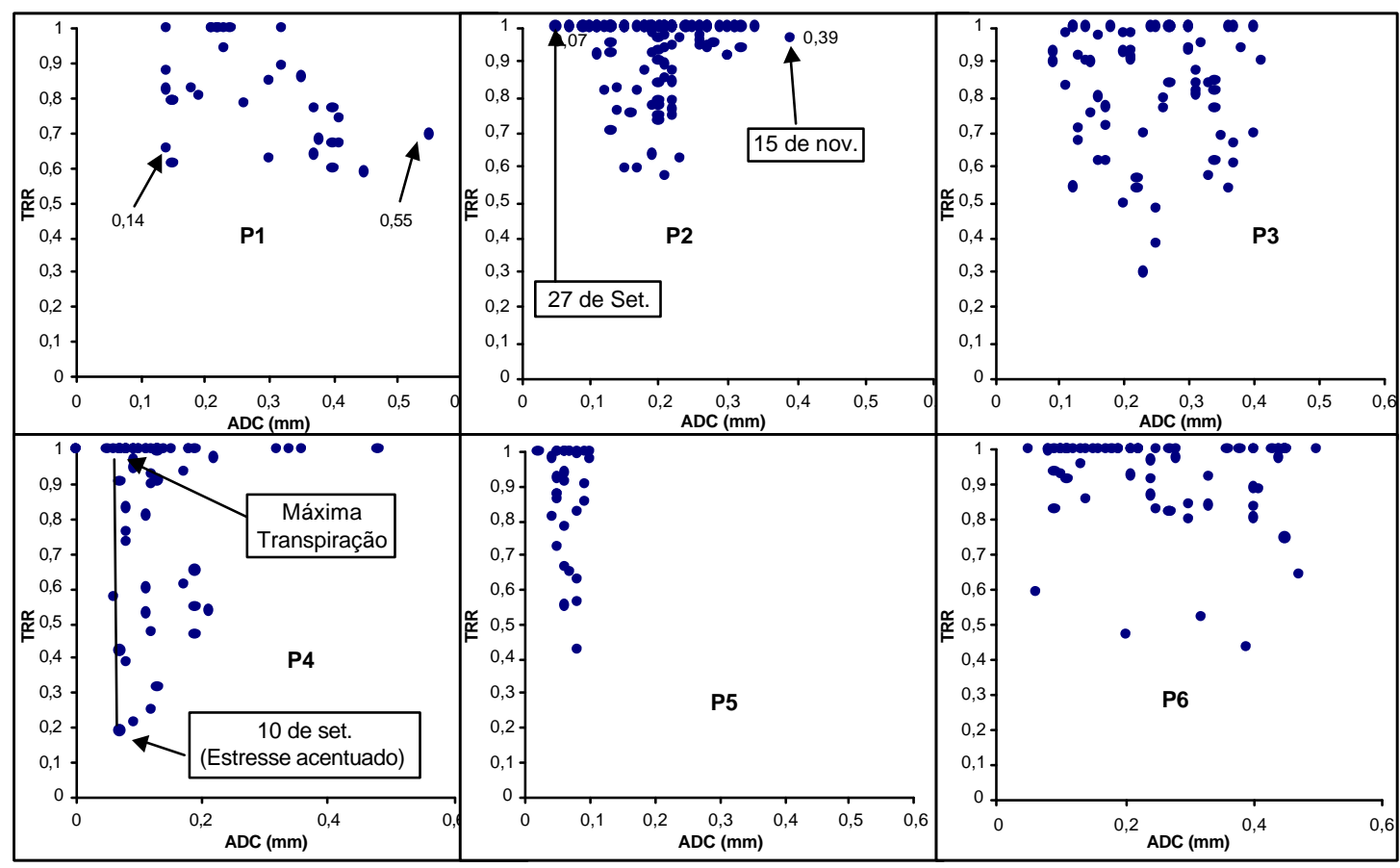

Figura 30 - Relação entre a amplitude diária de contração e a transpiração relativa em seis plantas jovens de lima ácida.

Observa-se pela figura que em todos os casos a dispersão dos dados é acentuada, não permitindo o estabelecimento de relações definidas entre as variáveis. A falta de correlação entre elas pode ser explicada pelos problemas e erros introduzidos por ambas.

Aparentemente o comportamento da ADC depende da espécie vegetal. Em planta de algodão, por exemplo, Kepper et al. (1973) observaram que ela aumentou quando a planta entrou em estresse hídrico. Huguet et al. (1992) observaram o contrário em macieira, ou seja, a ADC diminuiu quando a planta entrou em estresse hídrico.

Analisando com maior detalhe a Figura 30 são observados diferentes valores de ADC para igual valor de TRR e vice-versa. Por exemplo, na Planta 1 (P1), observa-se 
dois valores extremos de $\mathrm{ADC}, 0,14$ e 0,55 , para valores similares de TRR $(=0,68)$, que indicam certo grau de deficiência hídrica da planta. O primeiro valor corresponde ao dia 31 de agosto (DJ=243), dia com baixa demanda evaporativa do ar (ver Anexo 3), enquanto que o segundo correspondente ao dia 25 de agosto ( $\mathrm{DJ}=237$ ), dia ensolarado com alta demanda evaporativa do ar (Fig. 31a). Observam-se numerosos casos similares, em que as plantas se encontram com a máxima transpiração, TRR=1, mas com valores de ADC muito dispersos.

Exemplo de um caso contrário, em que para valores similares de ADC correspondem valores extremos de TRR, é visto na planta 4 da Figura 30. No dia 10 de setembro $(\mathrm{DJ}=253)$ ao valor de $\mathrm{TRR}=0,19$ (deficiência hídrica acentuada, como indicado também pelo potencial mátrico do solo, Figura 29) corresponde o valor de $\mathrm{ADC}=0,07$. Por outro lado, para o mesmo valor de $\mathrm{ADC}$ o valor de $\mathrm{TRR}=1$ (máxima taxa de transpiração), no dia 5 de outubro ( $\mathrm{DJ}=278$ ). Ambos os dias se caracterizaram pela alta demanda evaporativa do ar, conforme os dados meteorológicos apresentados nos Anexos 2 a 5. Na figura 31b é observado com maior detalhe tal comportamento.

Em todas as plantas foram observados valores discrepantes que confirmam a observação de Garnier \& Berger (1986) e de Ginestar \& Castel (1998) de que a ADC, além de obedecer à condição hídrica da planta, é função, também, dos elementos meteorológicos e da própria demanda evaporativa do ar.

Um dos comportamentos típicos da $\mathrm{ADC}$ é que ela atinge um valor alto quando a planta começa a sofrer déficit hídrico; no entanto, o comportamento é similar logo após uma irrigação, possivelmente devido à reação natural do xilema a uma nova situação onde precisa atingir seu estado normal (Goldhamer et al., 1999). Segundo Ginestar \& Castel (1998), nessa condição, apesar da planta estar com a máxima taxa de transpiração, ou seja, igual a da planta-controle, a sua ADC é sempre maior do que desta última.

O comportamento de se ter valores idênticos da ADC para diferentes condições hídricas de planta também foi observado por Moriana et al. (2000) para oliveira, ao relacionarem a $\mathrm{ADC}$ com o potencial da água do caule no meio do dia. Por outro lado, 
para a dispersão dos dados da Figura 30 e, também das relações discutidos nos itens 4.2.2.4 e 4.2.2.5 podem ter concorrido os erros na estimativa de TRR. O significado e os erros relativos a TRR serão discutidos na análise da evolução dessa variável.
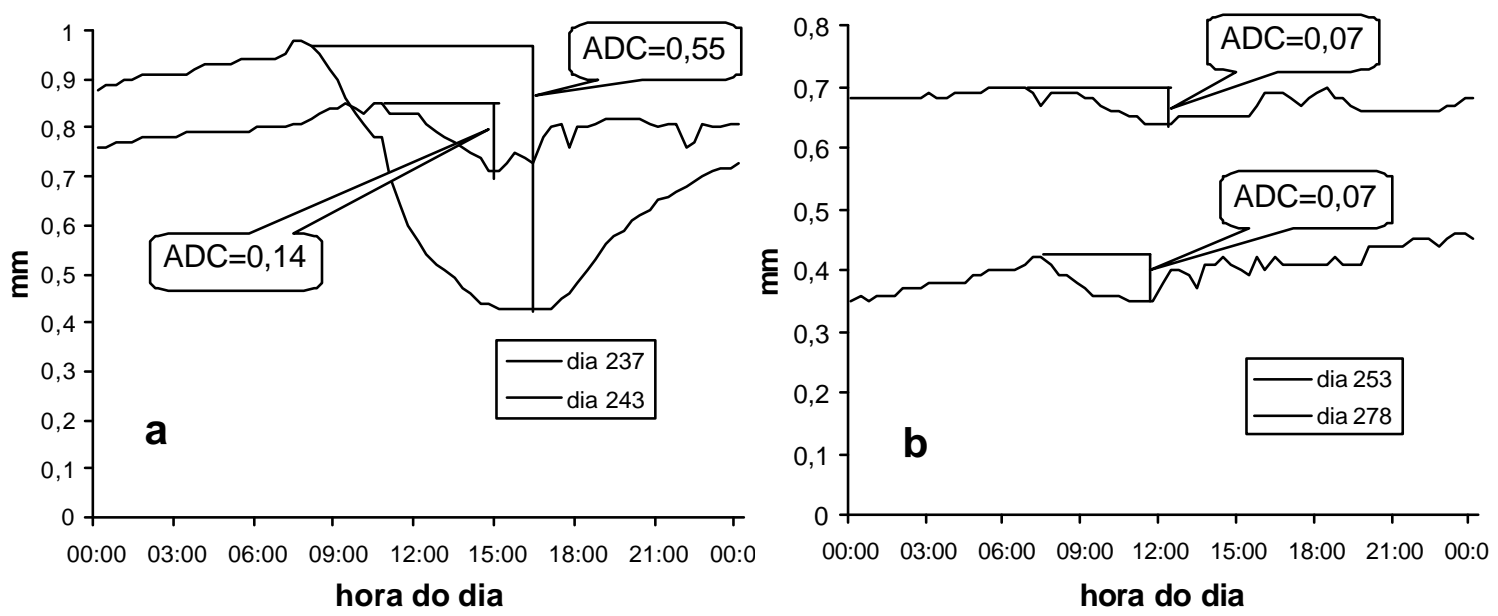

Figura 31 - Exemplos da variação radial do diâmetro do tronco de limoeiro, indicando valores diferentes de ADC para igual valor de TRR (a) e indicando iguais valores de ADC para diferentes valores de TRR (b).

\subsubsection{Exemplos entre a evolução do diâmetro máximo do ramo (DMax) e a transpiração relativa $(T R R)$}

Na Figura 32 são observadas as relações entre o DMax e a TRR para as seis plantas estudadas. Observa-se que, apesar dos pontos serem menos dispersos que da relação entre TRR e $\mathrm{ADC}$, igualmente não se tem uma clara tendência. Conforme a literatura consultada, uma tendência esperada seria uma curva como a que se observa na planta 1 da Figura 32 (linha tracejada); ou seja, se a planta estiver com bom suprimento hídrico, o órgão vegetal teria um crescimento ativo e continuo. Nesse caso, o DMax sempre terá valor positivo. Quando a planta começa a sofrer estresse hídrico, o DMax ficará cada vez mais perto do zero até passar a ter valor negativo, indicando uma deficiência hídrica cada vez mais acentuada da planta. No entanto, conforme o que se observa o comportamento dessa relação não acontece, possivelmente, devido aos mesmos motivos explicados no item anterior; ou seja, além de responder à condição 
hídrica da planta, o DMax também depende de outros fatores ambientais, entre eles a demanda evaporativa do ar.

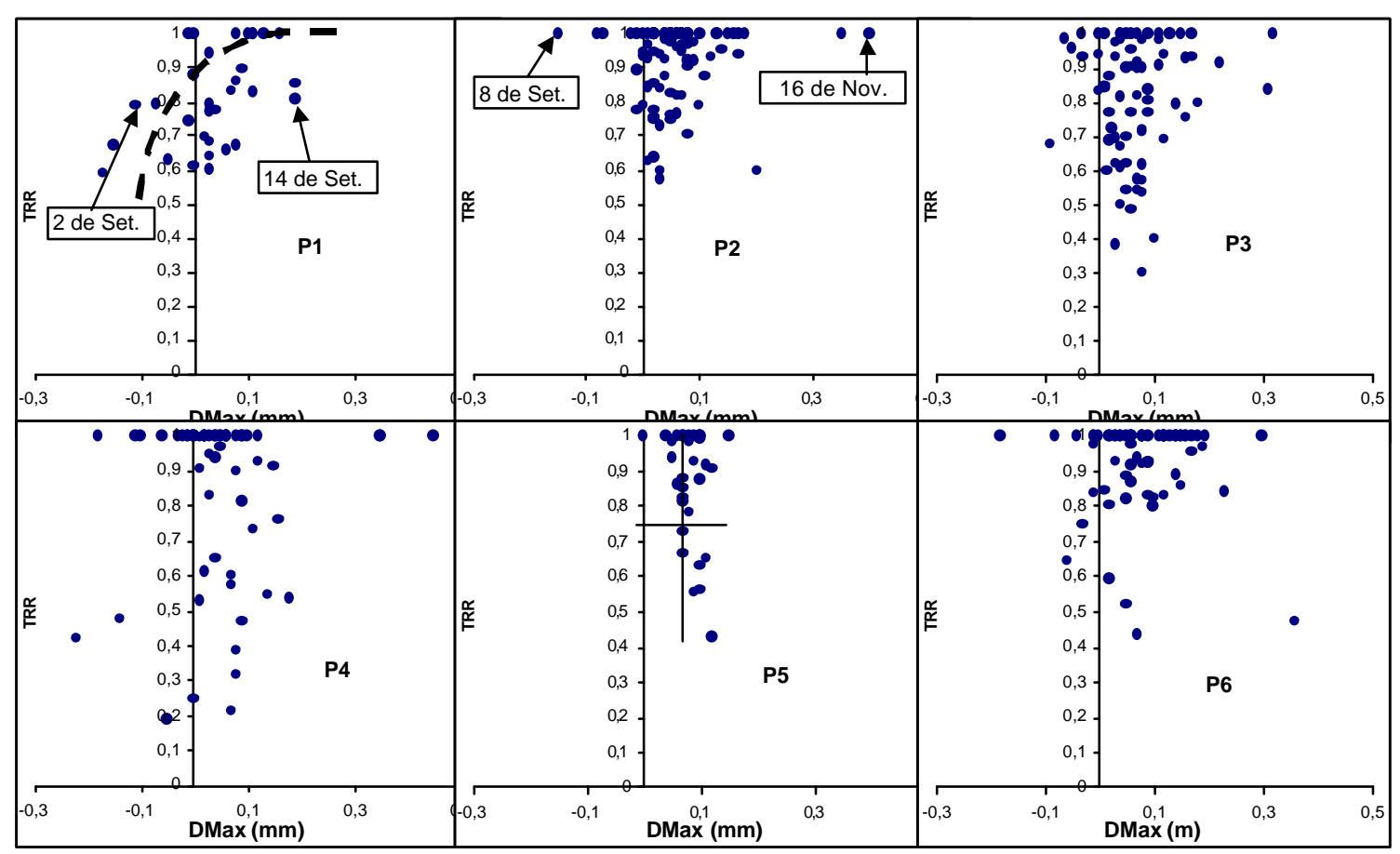

Figura 32 - Relação entre a variação do diâmetro máximo (DMax) e a transpiração relativa $(\mathrm{TRR})$ em seis plantas.

Os poucos valores negativos do DMax, observados na figura são devidos ao crescimento ativo das plantas jovens, de tal maneira que esse crescimento supera a contração do órgão, apesar de terem sofrido estresse hídrico intermitente.

Pode-se observar que iguais valores de DMax podem indicar diferentes valores de TRR e vice-versa. Por exemplo, a planta 1 da Figura 32, no dia 14 de setembro (DJ=257), apesar de ter sofrido pequeno estresse hídrico (TRR=0,8), mostrou crescimento radial do ramo, indicado pelo valor positivo de DMax. No entanto, no dia 2 de setembro $(\mathrm{DJ}=245)$, apesar de se observar o mesmo valor de $\mathrm{TRR}$, tem-se valores negativo de DMax, mostrando uma contração do diâmetro do ramo. A diferença entre ambas as situações pode ser melhor compreendida observando a Tabela 3 e a Figura 33(P1). No dia 2 de setembro o solo encontrava-se com baixa disponibilidade hídrica, exceto na camada dos $10 \mathrm{~cm}$, devido aos $18 \mathrm{~mm}$ de chuva acumulada nos últimos quatro 
dias, enquanto que, no dia 14 de setembro o solo já se encontrava com maior disponibilidade hídrica, mas ainda com certa restrição para a planta. A possível causa da diminuição do diâmetro do ramo no dia 2 de setembro foi a maior demanda hídrica do ar para uma planta com muita restrição hídrica, enquanto que, no dia 14 de setembro, a planta não teve uma exigência muito grande de parte do meio ambiente, conseguindo crescer apesar da restrição hídrica no solo.
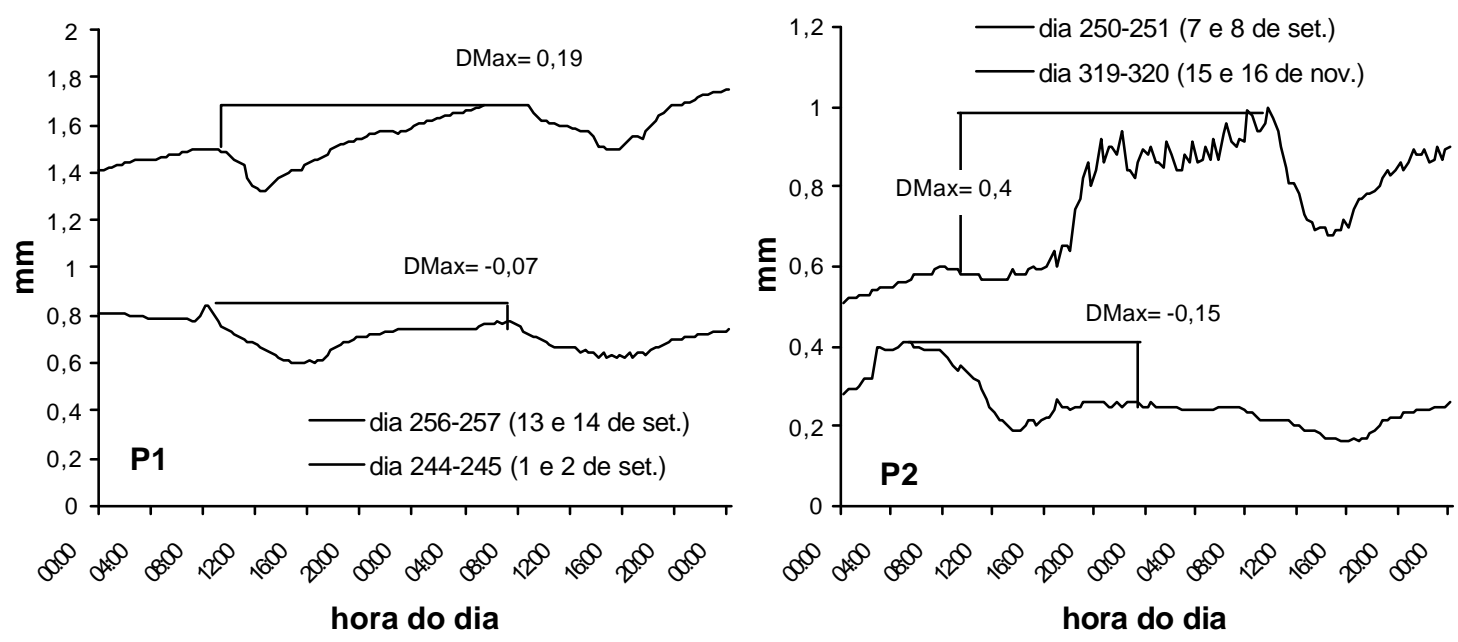

Figura 33 - Evolução da variação radial do diâmetro do caule de duas plantas de lima ácida (P1 e P2) durante dois dias consecutivos. P1 corresponde a duas situações em que ocorre deficiência hídrica, $\mathrm{TRR}=0,8$, com diferentes valores de DMax. P2 corresponde à duas situações em que não há indicação de deficiência hídrica $(T R R=1)$, mas com diferentes valores de DMax.

Tabela 7. Valores de temperatura média (Tmed), umidade relativa média (UR), radiação solar global $(R G)$, radiação líquida $(R N)$, evapotranspiração potencial (ETp) e do potencial matricial (PM) médio em cada profundidade na planta 1 (P1) nos dias 2 e 14 de setembro de 2002.

\begin{tabular}{|c|c|c|c|c|c|c|c|c|c|}
\hline \multirow[t]{2}{*}{ Dia } & \multicolumn{4}{|c|}{$\mathbf{P M}(\mathrm{kPa})$} & \multirow{2}{*}{$\begin{array}{c}\text { Tmed } \\
\left({ }^{\circ} \mathrm{C}\right)\end{array}$} & \multirow{2}{*}{$\begin{array}{l}\text { UR } \\
(\%)\end{array}$} & \multirow{2}{*}{\multicolumn{2}{|c|}{$\begin{array}{cr}\mathbf{R G} & \mathbf{R N} \\
\left(\mathrm{MJ} \mathrm{m}^{-2} \mathrm{dia}^{-1}\right)\end{array}$}} & \multirow{2}{*}{$\begin{array}{c}\text { ETp } \\
(\mathrm{mm} / \mathrm{d})\end{array}$} \\
\hline & $0,1 \mathrm{~m}$ & $0,2 \mathrm{~m}$ & $0,3 \mathrm{~m}$ & $0,5 \mathrm{~m}$ & & & & & \\
\hline $2 \mathrm{de}$ & . & -75 & -82 & -83 & 12,7 & 55 & 24,98 & 9,56 & 3,31 \\
\hline 14 de Setembro & -16 & -46 & -45 & -60 & 22,6 & 71 & 10,48 & 4,78 & 2,12 \\
\hline
\end{tabular}

$\mathrm{PM}=$ potencial mátrico médio a 4 profundidades, $\mathrm{T}=$ temperatura média do ar, $\mathrm{UR}=$ umidade relativa média do ar, $\mathrm{RG}=$ radiação global, $\mathrm{RN}$ = radiação neta e ETPpm= evapotranspiração potencial calculado pelo método de Penman \& Monteith. 
No dia 16 de novembro ( $\mathrm{DJ}=320$ ), na planta 2 ( $\mathrm{P} 2$ da figura 32), observa-se um comportamento esperado, DMax=0,4, em que após uma chuva abundante tem-se um dia com alta demanda evaporativa do ar e máxima taxa de transpiração da planta $(T R R=1)$. Por outro lado, no dia 8 de setembro (DJ=251) observou-se um valor negativo de DMax $(=-0,15)$, também para uma taxa máxima de transpiração. Neste último caso, três dias antes dessa data, a planta estava entrando em estresse hídrico. Na madrugada do dia anterior houve uma chuva de $11 \mathrm{~mm}$ que ocasionou um aumento do diâmetro do caule, mas no dia 251, mesmo ocorrendo $T R R=1$, ocorreu uma diminuição do diâmetro máximo e do próprio diâmetro médio do caule (Fig. 33, P2).

Em síntese, de maneira idêntica à ADC, a relação entre DMax e TRR mostrourse altamente dispersa porque a demanda atmosférica tem grande peso no comportamento do DMax, juntamente com a própria condição hídrica da planta.

\subsubsection{Relação entre a evolução do diâmetro mínimo do ramo (DMin) e a transpiração relativa $(\mathrm{TRR})$}

Poucos são os autores que utilizaram DMin como indicador de déficit hídrico, pois ele tem comportamento muito parecido ao DMax. Goldhamer et al. (1999), afirmam que em pêssego este parâmetro é mais sensível do que ADC e DMax. No entanto, conforme a Figura 34, em plantas de lima ácida 'Tahiti', podem ser evidenciados que a dispersão entre DMin e TRR é tão grande quanto a encontrada para as duas outras variáveis. Isso ocorre porque o diâmetro mínimo do caule é altamente dependente da demanda atmosférica, sendo provavelmente mais dependente do que o próprio DMax, pois o diâmetro mínimo ocorre no período do dia de maior demanda. 


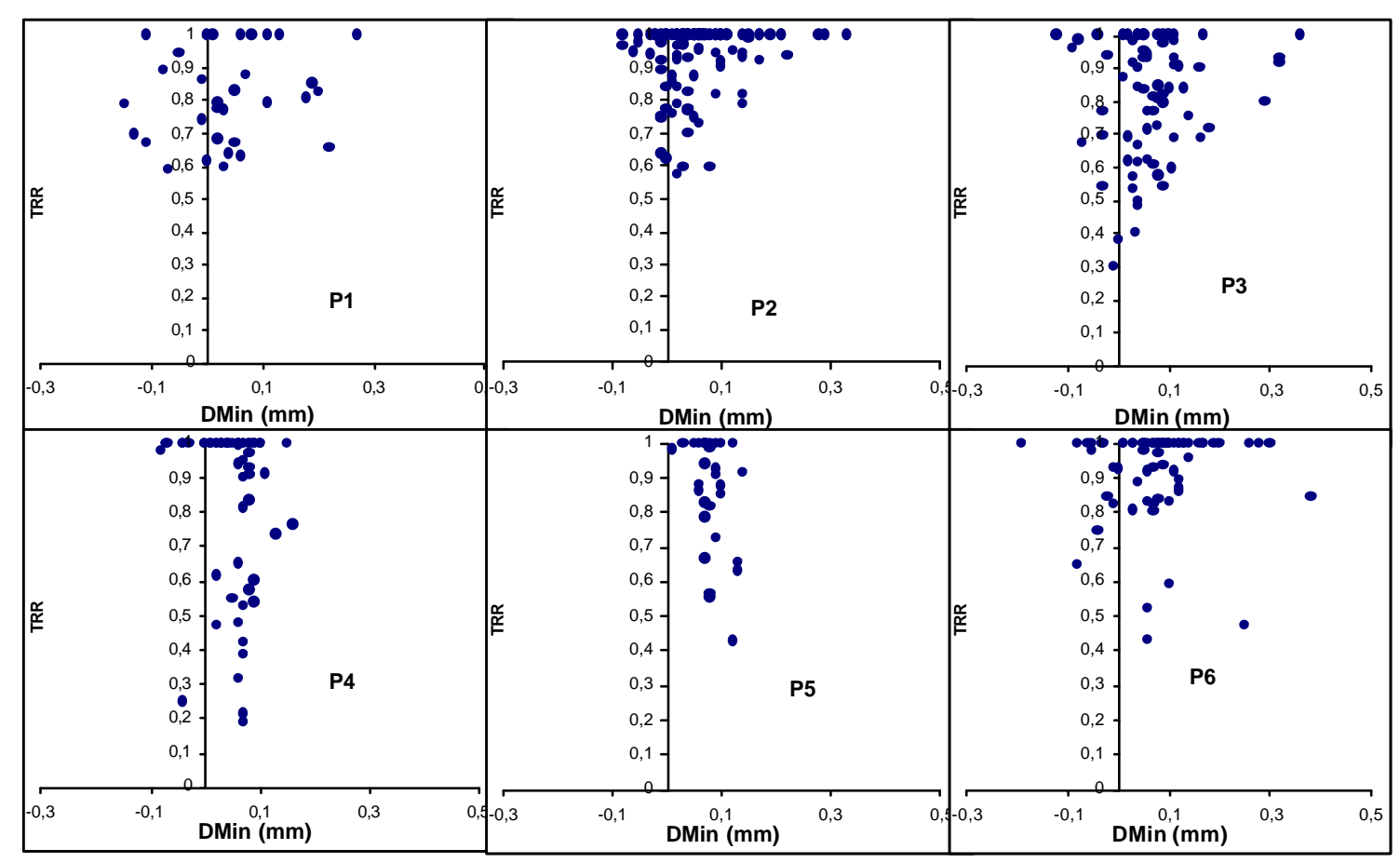

Figura 34 - Relação entre a evolução do diâmetro máximo (DMin) e a transpiração relativa (TRR) em seis plantas.

\subsubsection{Análise da evolução temporal da transpiração relativa e do diâmetro do caule e de ramos}

Tendo em vista a dificuldade de se encontrar uma relação definida entre a TRR e as variáveis obtidas a partir das medidas dendrométricas, de maneira que fosse possível avaliar o significado das variações de ADC, DMax e DMin como indicadores das condições hídricas das plantas jovens, procedeu-se então à análise da variação temporal de TRR e do diâmetro do caule, com intuito de se tentar associar essas variações com o déficit hídrico a que as plantas estiveram submetidas. Para isso, foram utilizadas as plantas adultas e as jovens.

A figura 35 mostra a evolução da variação radial de ramos de duas plantas adultas de lima ácida 'Tahiti' entre os dias 293 e 344. Comparando-se a evolução da variação radial com a de potencial mátrico da água do solo das duas plantas (Figura 27), é possível verificar que a planta 4 (controle) não sofreu deficiência hídrica no solo do dia 
302 ao 318, mantendo nesse período um padrão de crescimento radial contínuo do ramo. Embora não sejam mostrados dados de potencial mátrico após o dia 318, a planta continuou sendo irrigada continuamente de modo que não deve ter sofrido estresse até o dia 344.



Figura 35 - Variação radial de ramo de duas plantas adultas de lima ácida 'Tahiti' ao longo dos dias juliano 293 a 344 de 2002. As setas indicam as lâminas de chuva e volume de água de irrigação, conforme os rótulos.

Por outro lado, a planta 1 sofreu uma secagem contínua do solo do dia 292 até o dia 311, quando ela foi irrigada com 864 litros de água. No período do dia 292 ao 299, o diâmetro do ramo não mostrou tendência de aumento, ou seja, o seu crescimento já se mostrava limitado. Com a acentuação da secagem do solo no período seguinte, houve tendência do caule se contrair bastante. No dia 301, por exemplo, todos os tensiômetros até a profundidade de $50 \mathrm{~cm}$ já estavam no limite da escala de sua utilização e houve uma diminuição dos valores médios do diâmetro nos dias 300, 301 e 302. Adveio, a seguir uma tendência de aumento do valor médio do diâmetro, para haver nova queda até o dia 311, período no qual o potencial mátrico da água do solo decresceu para valores muito baixos. Após a irrigação no dia 311 e as chuvas do dia 315 ao 323, a retomada da tendência de crescimento dos valores médios da variação radial é percebida 
na figura, até que do dia 325 ao 329 manifesta-se de novo uma tendência de estabilização seguida de retomada de crescimento.

Assim, a análise da variação média do diâmetro do ramo parece ser um critério a ser adotado para se definir se o grau de deficiência hídrica é limitante ao crescimento do caule ou ramos. Independente da variação diária (ADC por exemplo) o comportamento dessa variação média ao longo do tempo pode indicar a necessidade de irrigação em lima ácida e nos citros em geral. A partir do momento em que se estabiliza o valor médio, deve-se estar atento, porque isso pode ser um prenúncio da ocorrência do estresse hídrico. É evidente que a paralisação do crescimento radial pode ocorrer por outros fatores, como diminuição da temperatura do ambiente, por exemplo. Mas, no caso mostrado, essa não foi a causa da estabilização do crescimento radial em certos períodos, porque trata-se de uma época de retomada de crescimento dos citros na região e, também, a temperatura do ar manteve-se sempre elevada.

Para maior aprofundamento de análise, a Figura 36 mostra a variação temporal do diâmetro máximo das duas árvores, assumindo-se que ele é um melhor indicador das condições hídricas da planta em resposta à disponibilidade hídrica do solo, pois ocorre no período do final da madrugada - início da manhã, no qual a demanda atmosférica é mínima e a recuperação do armazenamento hídrico da planta ocorre a noite em função da própria disponibilidade hídrica no solo.

As observações feitas nos parágrafos anteriores, entre a associação da variação de diâmetro médio e a disponibilidade hídrica no solo valem para o diâmetro máximo, como mostra a Figura 36. 


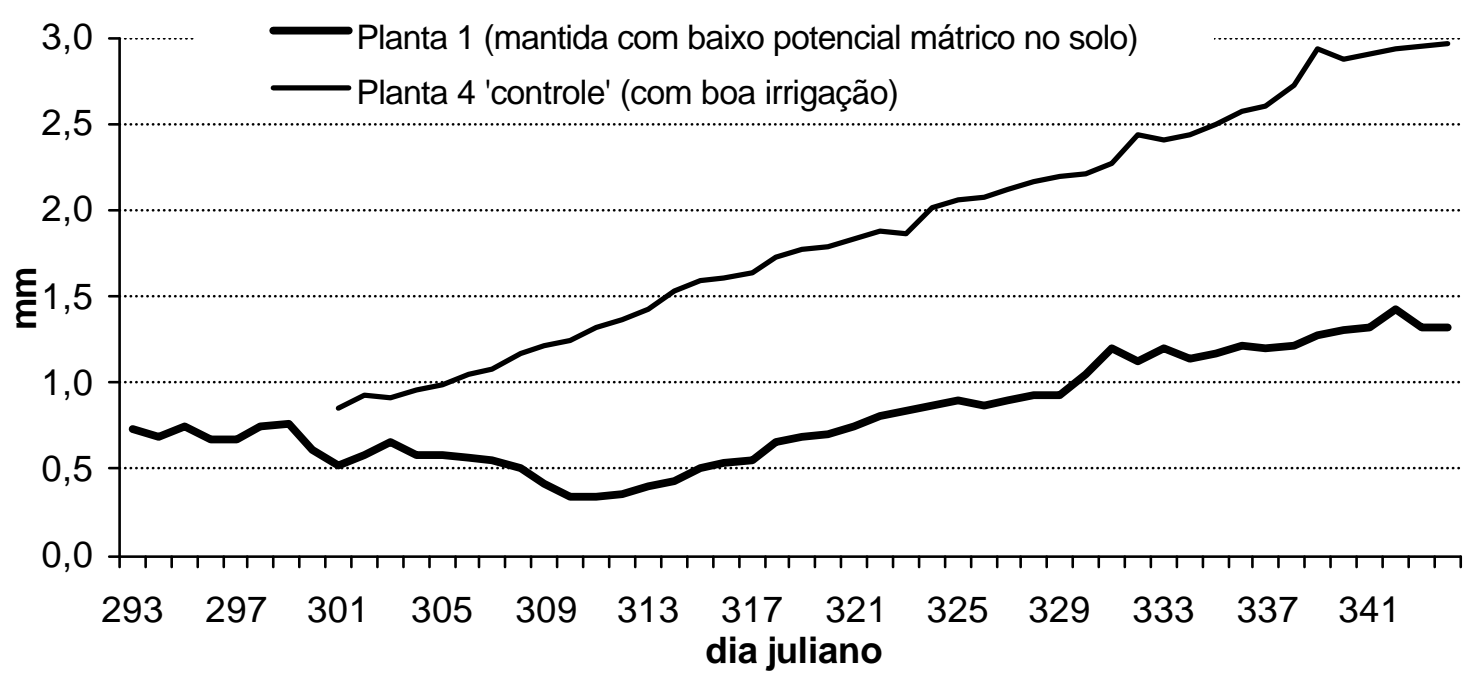

Figura 36 - Evolução ao longo do tempo, do diâmetro máximo de ramos de duas árvores de lima ácida 'Tahiti' entre os dias julianos 293 e 344 de 2002.

As Figuras 37, 38 e 39 referem-se às plantas estudadas no pomar de plantas jovens podendo auxiliar na análise não somente da evolução temporal do diâmetro máximo, mas também da transpiração relativa e o significado de ambas quanto a indicarem as condições hídricas das plantas de lima ácida.

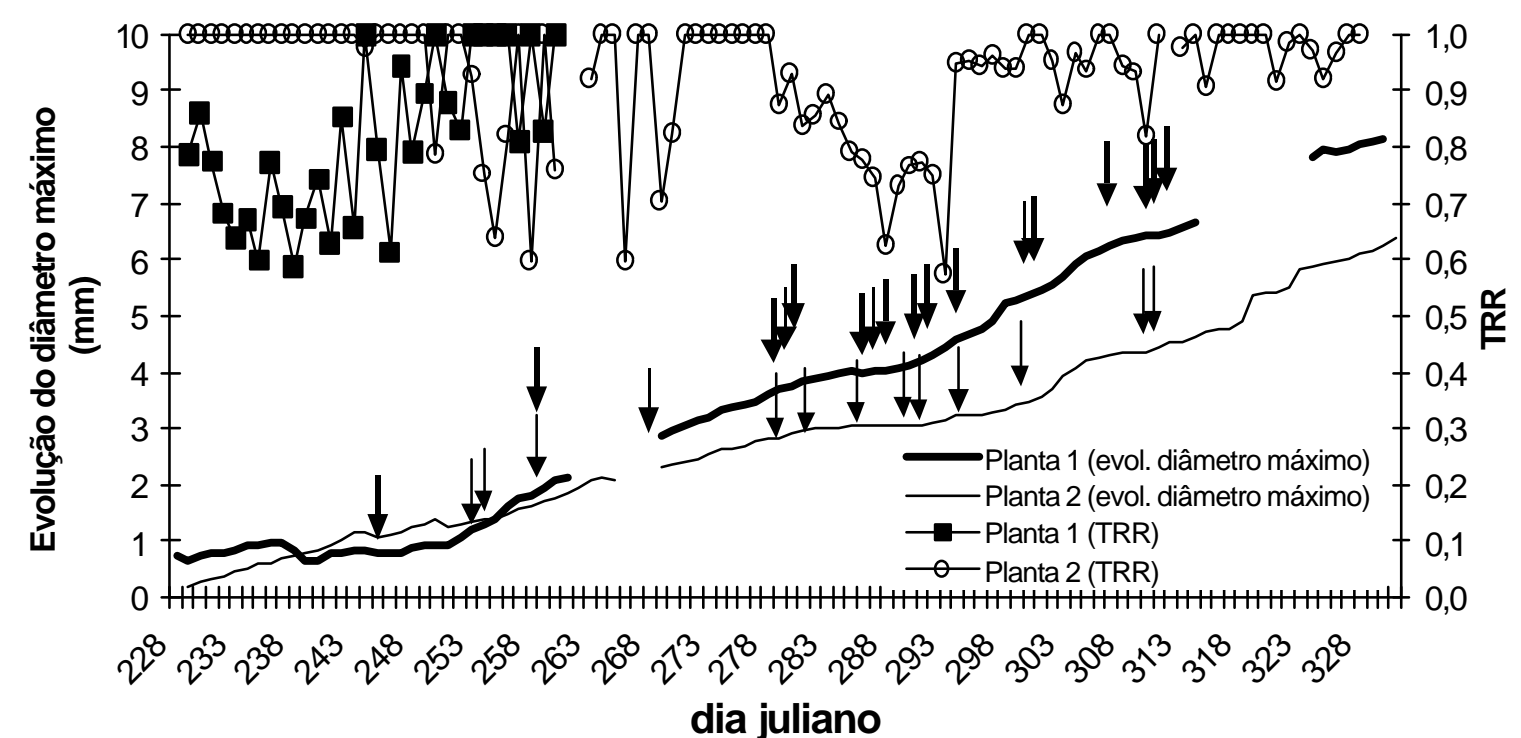

Figura 37 - Evolução temporal do diâmetro máximo do caule e da transpiração relativa (TRR) de duas plantas jovem de lima ácida 'Tahiti' (plantas 1 e 2). 


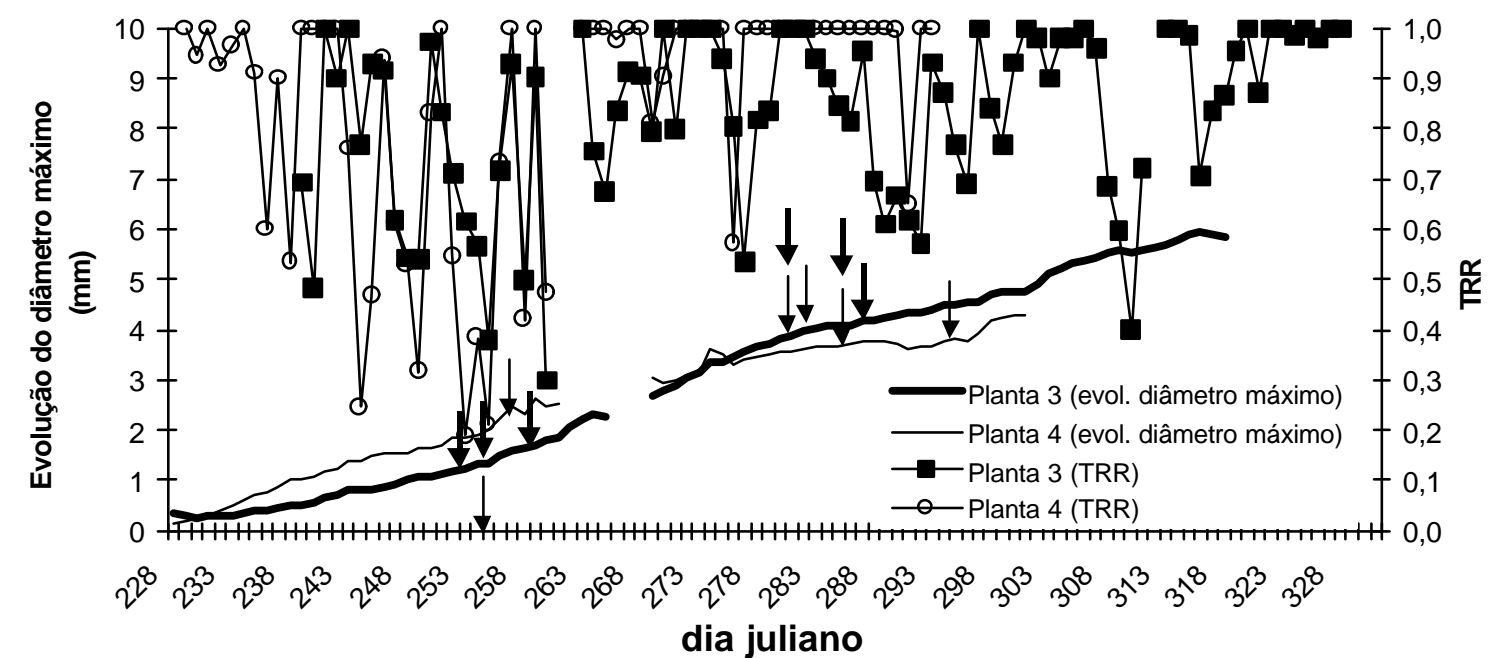

Figura 38 - Evolução temporal do diâmetro máximo do caule e da transpiração relativa (TRR) de duas plantas jovem de lima ácida 'Tahiti' (plantas 3 e 4).

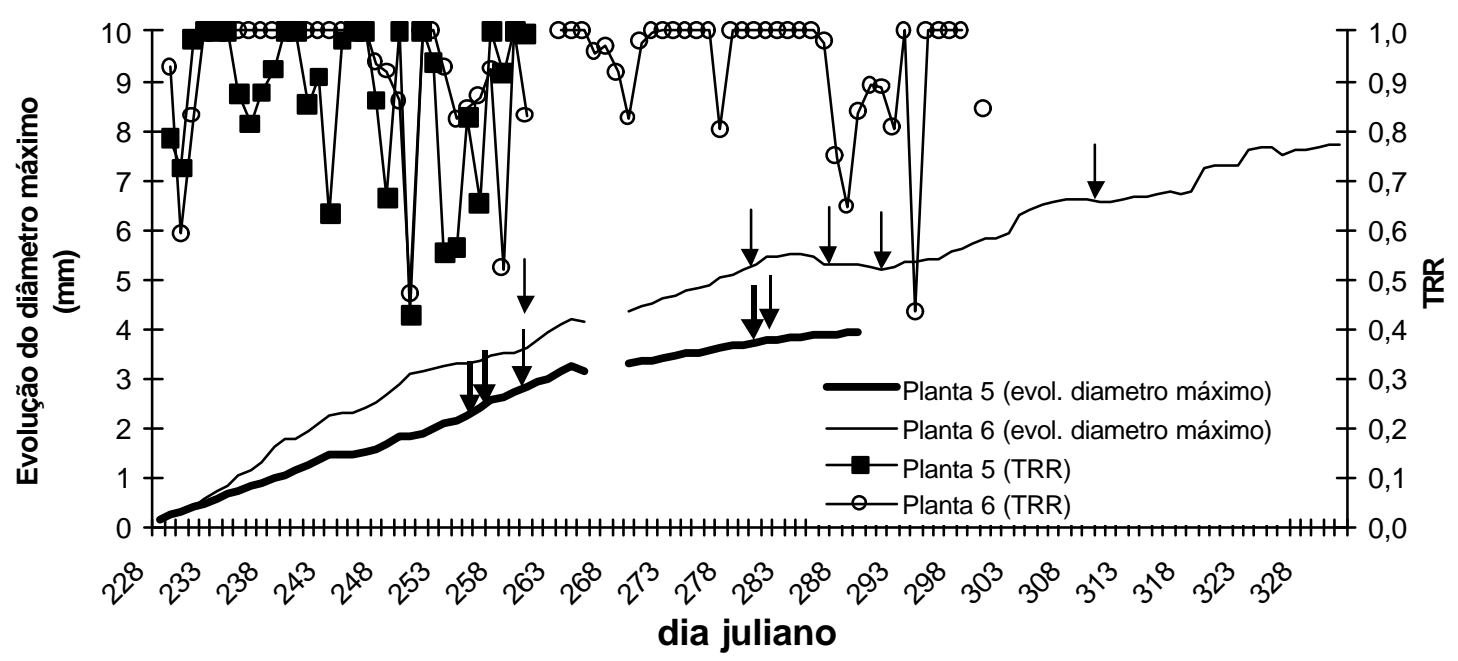

Figura 39 - Evolução temporal do diâmetro máximo do caule e da transpiração relativa (TRR) de duas plantas jovem de lima ácida 'Tahiti' (plantas 5 e 6).

Analisando a evolução de TRR para cada planta e associando com a evolução do potencial mátrico da água do solo (Figuras 28 e 29), verifica-se alguma dificuldade em interpretar a variação de TRR como um indicador da disponibilidade hídrica do solo e das condições hídricas das plantas.

A planta 1, por exemplo, apresenta entre os dias 228 e 245 valores TRR mínimo de 0,6, em relação direta com a diminuição do potencial mátrico da água do solo, mas depois a TRR estabiliza-se praticamente em 1, com exceção de alguns dias entre DJ 245 
e 250, onde ocorrem oscilações de TRR entre 0,6 e 1. A resposta dendrométrica evidencia uma diminuição do DMax entre DJ 237 e 240 seguido de aumento nos dias 241e 242, e de estabilização de 243 a 246, para então aumentar de novo até o último dia de medida de dendrômetro.

Entretanto, as plantas 2 e 3 experimentaram uma restrição hídrica talvez não acentuada no período entre DJ 236 e 240, no qual os tensiômetros acusaram potencial mátrico entre -70 e $-85 \mathrm{kPa}$ nas profundidades de 0,$2 ; 0,3$ e $0,5 \mathrm{~m}$ e mais negativamente ainda (fora da escala mensurável pelos tensiômetros) a 0,10 m. Para essas plantas os dados dendrométricos não acusaram perturbação do crescimento dos valores de diâmetro máximo no período, e TRR praticamente manteve-se constante em torno do valor máximo. Nesse mesmo período, as plantas 4, 5 e 6 sofreram menor restrição hídrica no solo que as plantas anteriores e as medidas dendrométricas não mostram diminuição de tendência do diâmetro máximo, mas a TRR apresentou um padrão oscilatório entre 1 e 0,6, aproximadamente. Embora se valores de TRR de 0,6 persistirem por vários dias, possam significar um razoável déficit hídrico da planta, quando ocorrem dentro de um padrão oscilatório como o observado nesse período, podem significar que a planta não apresenta déficit hídrico suficiente para interferir no seu crescimento. Deve-se ressaltar que esse caráter oscilatório da TRR pode ser consequiência de característica de espécies cítricas, que tem um mecanismo regulatório da perda de água bem marcante. Nas plantas 3 e 4, o padrão oscilatório nesse período foi mais acentuado, pois valores mínimos de 0,3 a 0,2 para TRR foram observados ao longo de todo o ciclo e somente uma leve tendência de diminuição do diâmetro máximo ocorreu entre os dias 290 e 294 na planta 4.

A planta 4 apresentou um leve decréscimo do valor de diâmetro máximo entre os dias 291 e 294, com decréscimo de TRR até 0,65 e aumento desta até 1,0 logo em seguida, o que não se mostrou uma característica (detecção de déficits por períodos pequenos) da medida dendrométrica. Uma diminuição de diâmetro máximo pode ser vista entre os dias 284 e 294 na planta 6. Ela ocorreu simultaneamente com a diminuição de TRR, com valor mínimo de 0,6, mas antecedeu de 4 dias a diminuição de TRR. É 
difícil explicar essa defasagem; é possível que possa ter ocorrido erro na estimativa de TRR nos primeiros dias. Isso pode ser justificado considerando-se que a medida dendrométrica é feita diretamente e deve refletir bem a diminuição da reserva hídrica do caule. Já a TRR representou uma determinação mais complexa e com fontes de erro que poderiam explicar porque ela se mantém no valor 1 quando o dendrômetro já registrava uma contração que podia indicar um déficit hídrico da planta.

\subsubsection{Discussão sobre o uso da transpiração relativa e dos parãmetros dendrométricos na determinação das condições hídricas de plantas cítricas.}

Tanto a transpiração relativa como a determinação das variações micrométricas do caule ou dos ramos têm sido estudadas como indicadores vegetais do déficit hídrico em plantas herbáceas e lenhosas. Das duas variáveis, a TRR tem sido menos estudada (Ameglio et al., 1997; Marsal et al., 2000). Por outro lado, os estudos de variação micromorfométrica são em maior número e vários parâmetros tem sido usados, como aqueles testados no presente trabalho (ADC, DMax e DMin). Embora os três venham sendo recomendados como variáveis adequadas para se detectar o início do estresse hídrico que exigiria o início da irrigação (Cohen et al., 1997; Goldhamer et al., 1999), outros trabalhos mostram que eles tem relações muito complexas com as condições hídricas do solo, demanda atmosférica e da própria resposta do vegetal à disponibilidade hídrica no solo, com diferenças de comportamento entre espécies (Huguet et al., 1992; Katerji et al., 1994; Ginestar \& Castel, 1998; Moriana et al., 2000), além de estarem relacionados à própria dimensão do caule ou ramo.

A dificuldade de se trabalhar com ADC, DMax e DMin como indicadores do estresse hídrico foi confirmada no presente estudo. Para a espécie cítrica aqui estudada, a variação dendrométrica representada pela evolução temporal do diâmetro máximo pode ser um índice mais adequado do que os outros três parâmetros, confirmando a conclusão de Ginestar \& Castel (1998) em mandarina (Citrus clementina Hort. Ex Tan.). No período de crescimento do caule ou ramo, uma estabilização ou diminuição do valor do 
diâmetro máximo ao longo dos dias na estação de crescimento pode ser um grande sinal de que o estresse hídrico é suficientemente acentuado para exigir reposição de água no solo. A própria evolução do diâmetro médio pode ser utilizada como um indicador, conforme observou-se nas Figuras 23 e 24 (p. 60 e 61) e como pode se inferir da Figura 35 (p. 76).

A transpiração relativa também mostrou-se com potencialidade de uso como indicador de déficit hídrico acentuado, embora pareça ser uma variável menos estável que a evolução do diâmetro máximo Além disso, ela apresenta maiores problemas de determinação, pois envolve a medida e a estimativa de área foliar e manutenção de uma ou mais planta-controle (sob condições ideais de água no solo), além de exigir o uso de método(s) de determinação do fluxo de seiva mais complexo(s) que a medida de variação radial micrométrica do caule ou ramo.

Recomenda-se outros estudos sobre o assunto com espécies cítricas, visto que eles são bastante escassos na literatura. Para trabalhos futuros, além dos resultados e conclusões obtidos no presente estudo, seria interessante considerar o uso de tratamentos mais específicos e diferenciados de regime hídrico do solo. Isso pode representar um certo obstáculo para trabalhos de campo, devido à dimensão das plantas e as dificuldades de controle da água no solo em certos períodos, em função das condições atmosféricas. Ressalte-se, também, que a resposta dos citros ao déficit hídrico no solo e à demanda atmosférica deve ser considerados à luz do conhecimento existente, tendo em vista as peculiaridades de plantas cítricas quanto ao desenvolvimento do seu sistema radicular e da parte aérea, bem como da sua morfologia das folhas, comportamento estomático e entrada em repouso em parte do ano.

Ao longo do ano a tendência de aumento do diâmetro do caule ou ramo é diferenciada entre plantas adultas e plantas jovens, como pode ser observado na Figura 40, com tendência do caule da planta jovem crescer proporcionalmente mais que o do ramo de planta adulta durante a época de crescimento; mesmo na época de repouso (no caso por estiagem), observou-se tendência de algum crescimento da planta jovem. Esse aspecto deverá ser considerado na interpretação das variações micromorfométricas. 


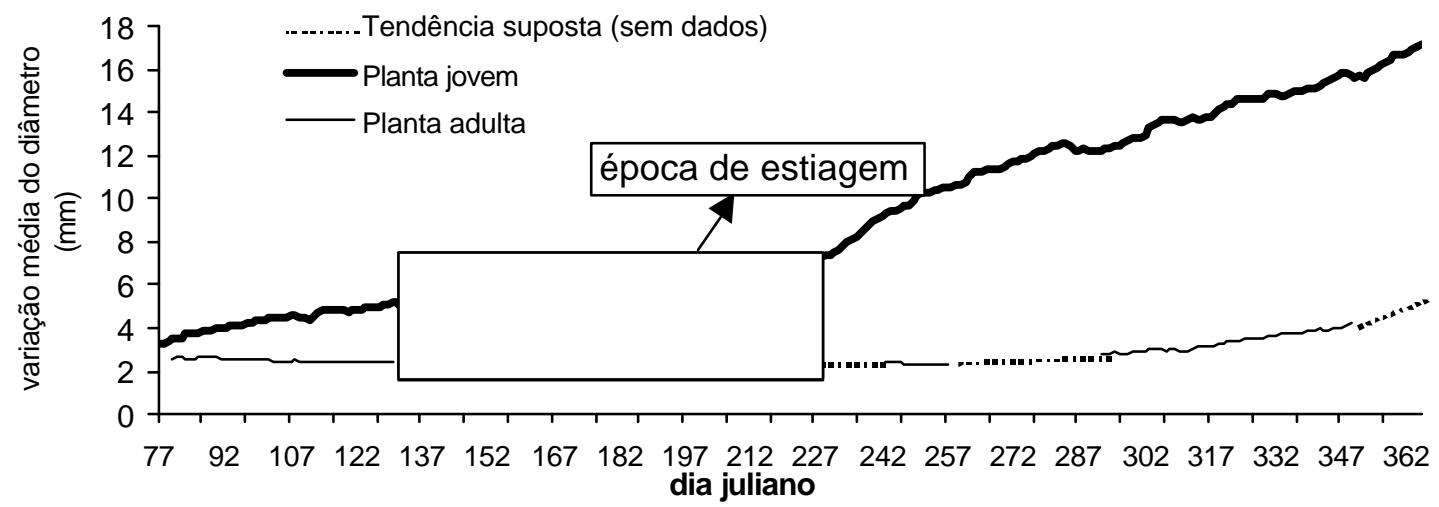

Figura 40 - Aumento do diâmetro médio do caule de uma planta jovem e uma planta adulta de lima ácida 'Tahiti', com tamanho aproximado de $4 \mathrm{~cm}$, durante o ano 2002. Fazenda Areão, ESALQ/USP. As linhas pontilhadas indicam estimativa em períodos em que as medidas não foram realizadas. 


\section{CONCLUSÕES}

- Os valores diários de fluxo de seiva determinados pelo método da sonda de dissipação térmica mostraram-se bem concordantes com o de transpiração medidos por lisimetria em plantas jovens de lima ácida 'Tahiti', desde que feita correção de erro devido à ocorrência de gradientes térmicos naturais no caule.

- Em plantas adultas de lima ácida, os resultados obtidos em um ramo mostraram valores discrepantes entre a sonda de dissipação térmica (SDT) e o método de balanço de calor (MBC), com valores maiores para este último. Ocorreram evidências de que se os valores fossem corrigidos para os possíveis erros embutidos nas estimativas do fluxo de seiva noturno e em parte da manhã no $\mathrm{MBC}$, e para os erros decorrentes do gradiente térmico natural no caule, as discrepâncias entre os valores obtidos nos dois métodos seriam minimizados.

- Os resultados obtidos sugerem que ambos os métodos, desde que usados com a devida cautela quanto aos erros descritos na conclusão anterior, podem fornecer resultados confiáveis de medida da transpiração diária de plantas jovens e adultas de lima ácida e, por extrapolação, de outras espécies cítricas no manejo da irrigação, principalmente de localizada. Nesse sentido, a SDT apresenta vantagens em relação ao $\mathrm{MBC}$ quanto à maior simplicidade e ao menor custo da técnica.

- A sensibilidade do dendrômetro de precisão mostrou-se adequada para detectar variações micrométricas do diâmetro do caule e ramos de lima ácida, em resposta à variação das condições hídricas da planta.

- Os parâmetros dendrométricos, amplitude diária de contração (ADC), diferença sequiencial dos valores diários máximos (DMax) e mínimos (DMin) do diâmetro do 
caule ou ramos mostraram-se de difícil uso como indicadores das condições hídricas de lima ácida, por estarem sujeitos aos efeitos da demanda atmosférica.

- O acompanhamento temporal da variação do diâmetro médio e do diâmetro máximo do caule e ramos com o dendrômetro de precisão mostrou-se uma técnica de potencialidade na deteç̧ão das condições hídricas da lima ácida e como indicador da necessidade de irrigação, pois a evolução temporal de ambos pode indicar quando o estresse hídrico começa a afetar o crescimento dos órgãos no período de crescimento vegetativo.

- A transpiração relativa tendeu a acompanhar a variação da disponibilidade hídrica do solo, mas demonstrou ser um indicador menos estável, menos sensível e de determinação e de interpretação mais complexas que as variações micrométricas, como indicador da necessidade de irrigação. 
ANEXOS 
Anexo 1 - Calendário Juliano

\begin{tabular}{|c|c|c|c|c|c|c|c|c|c|c|c|c|c|c|c|c|c|c|c|c|c|c|c|c|c|c|c|c|c|c|c|}
\hline & 1 & 2 & 3 & 4 & 5 & 6 & 7 & 8 & 9 & 10 & 11 & 12 & 13 & 14 & 15 & 16 & 17 & 18 & 319 & 20 & 21 & 22 & 23 & 24 & 25 & 26 & 27 & 28 & 29 & 30 & 31 \\
\hline JAN & 1 & 2 & 3 & 1 & 5 & 6 & 7 & 8 & 9 & 10 & 11 & 12 & 13 & 14 & 15 & 16 & 17 & 18 & 19 & 20 & 21 & 22 & 23 & 24 & 25 & 26 & 27 & 28 & 29 & 30 & 31 \\
\hline FEV & 32 & 33 & 34 & 35 & 36 & 37 & 38 & 39 & 40 & 41 & 42 & 43 & 44 & 45 & 46 & 47 & 48 & 49 & 50 & 51 & 52 & 53 & 54 & 55 & 56 & 57 & 58 & 59 & 60 & & \\
\hline MAR & 60 & 61 & 62 & 63 & 64 & 65 & 66 & 67 & 68 & 69 & 70 & 71 & 72 & 73 & 74 & 75 & 76 & 77 & 78 & 79 & 80 & 81 & 82 & 83 & 84 & 85 & 86 & 87 & 88 & 89 & 90 \\
\hline ABR & 91 & 92 & 93 & 94 & 95 & 96 & 97 & 98 & 99 & 100 & 101 & 102 & 103 & 104 & 105 & 106 & 107 & 108 & 3109 & 110 & 111 & 112 & 113 & 114 & 115 & 116 & 117 & 118 & 119 & 120 & \\
\hline MAI & 121 & 122 & 123 & 124 & 125 & 126 & 127 & 128 & 3129 & 130 & 131 & 132 & 133 & 134 & 135 & 136 & 137 & 138 & 3139 & 140 & 141 & 142 & 143 & 144 & 145 & 146 & 147 & 148 & 149 & 150 & 151 \\
\hline JUN & 152 & 153 & 154 & 155 & 156 & 157 & 158 & 159 & 160 & 161 & 162 & 163 & 164 & 165 & 166 & 167 & 168 & 169 & 170 & 171 & 172 & 173 & 174 & 175 & 76 & 177 & 178 & 179 & 180 & 181 & \\
\hline JUL & 182 & 183 & 184 & 185 & 186 & 187 & 188 & 189 & 190 & 191 & 192 & 93 & 194 & 195 & 196 & 197 & 198 & 199 & 200 & 201 & 202 & 203 & 204 & 205 & 06 & 207 & 08 & 209 & 210 & 211 & 212 \\
\hline $\mathrm{AGO}$ & 213 & 214 & 215 & 216 & 217 & 218 & 219 & 220 & 221 & 222 & 223 & 224 & 225 & 226 & 227 & 228 & 229 & 230 & 231 & 232 & 233 & 234 & 235 & 236 & 37 & 238 & 39 & 240 & 241 & 24 & 243 \\
\hline SET & 244 & 245 & 246 & 247 & 248 & 249 & 250 & 251 & 252 & 253 & 254 & 255 & 256 & 257 & 258 & 259 & 260 & 261 & 262 & 263 & 264 & 265 & 266 & 267 & 268 & 269 & 270 & 271 & 272 & 273 & \\
\hline OUT & 274 & 275 & 276 & 277 & 278 & 279 & 280 & 281 & 282 & 283 & 284 & 285 & 286 & 287 & 288 & 289 & 290 & 291 & 292 & 293 & 294 & 295 & 296 & 297 & 298 & 299 & 300 & 301 & 302 & 30 & 30 \\
\hline NOV & 305 & 306 & 307 & 308 & 309 & 310 & 311 & 312 & 313 & 314 & 315 & 316 & 317 & 318 & 319 & 320 & 321 & 322 & 323 & 324 & 325 & 326 & 327 & 328 & 329 & 330 & 331 & 332 & 333 & 334 & \\
\hline DEZ & 335 & 336 & 337 & 338 & 339 & 340 & 341 & 342 & 343 & 344 & 345 & 346 & 347 & 348 & 349 & 350 & 351 & 352 & 353 & 354 & 355 & 356 & 357 & 358 & 359 & 360 & 361 & 362 & 363 & 364 & 365 \\
\hline
\end{tabular}


Anexo 2 - Dados meteorológicos do mês de agosto de 2002. Fazenda Areão, ESALQ, Piracicaba/SP.

\begin{tabular}{|c|c|c|c|c|c|c|c|c|c|c|c|c|c|c|c|}
\hline \multirow[t]{3}{*}{ Dia } & \multicolumn{3}{|c|}{ TEMPER. DO AR $\left({ }^{\circ} \mathrm{C}\right)$} & \multicolumn{3}{|c|}{ UMIDADE RELATIVA (\%) } & \multicolumn{2}{|c|}{ Vento } & \multirow{3}{*}{$\begin{array}{l}\text { Chuva } \\
(\mathrm{mm})\end{array}$} & \multirow[b]{3}{*}{ (M. } & \multirow[t]{2}{*}{$\overline{R n}$} & \multirow[t]{3}{*}{$G$} & \multirow[t]{2}{*}{ es } & \multirow{2}{*}{$\begin{array}{c}\text { ETo } \\
\text { (ECA) }\end{array}$} & \multirow{2}{*}{$\begin{array}{r}\text { ETo-PM } \\
(\mathrm{FAO})\end{array}$} \\
\hline & Máx. & Mín. & Méd. & Máx. & Mín. & Méd. & Veloc. & Direc. & & & & & & & \\
\hline & & $\left({ }^{\circ} \mathrm{C}\right)$ & & & $(\%)$ & & $(\mathrm{m} / \mathrm{s})$ & $\left(G^{\circ}\right)$ & & & $\left(\mathrm{MJ} \mathrm{m}^{-2} \mathrm{dia}^{-1}\right)$ & & $(\mathrm{kPa})$ & \multicolumn{2}{|c|}{$(\mathrm{mm})$} \\
\hline 1 & 22,32 & 16,76 & 18,58 & 96 & 73,3 & 91,3 & 1,11 & 118,5 & 39,4 & 5,58 & 2,57 & 0,06 & 2,14 & 0,82 & 0,82 \\
\hline 2 & 20,33 & 15,61 & 17,71 & 96,9 & 78,1 & 91 & 0,91 & 143,1 & 22,4 & 6 & 2,92 & 0,09 & 2,03 & 0,86 & 0,86 \\
\hline 3 & 22,6 & 15,68 & 18,2 & 96,9 & 65,78 & 86,8 & 0,86 & 221 & 3,5 & 7,55 & 3,74 & 0,05 & 2,09 & 1,23 & 1,17 \\
\hline 4 & 28,36 & 11,59 & 19,37 & 97,4 & 40,18 & 75,1 & 0,55 & 119,9 & 0,1 & 18,05 & 9,06 & 0,45 & 2,25 & 2,52 & 2,66 \\
\hline 5 & 32,01 & 14,28 & 22,23 & 96,4 & 30,51 & 69,16 & 1,31 & 118,7 & 0 & 15,15 & 6,94 & 0,13 & 2,68 & 3,65 & 2,9 \\
\hline 6 & 29,6 & 15,81 & 21,04 & 95,8 & 43,21 & 79,1 & 1,28 & 85,7 & 3,8 & 14,6 & 7,11 & 0,11 & 2,49 & 2,45 & 2,45 \\
\hline 7 & 31,31 & 15,28 & 22,39 & 96,5 & 30,91 & 69,22 & 1,09 & 69,07 & 0 & 18,1 & 9,08 & 0,36 & 2,71 & 3,17 & 3,25 \\
\hline 8 & 32,54 & 15,47 & 22,72 & 94,8 & 23,43 & 65,43 & 1,38 & 88,2 & 0 & 18 & 8,14 & 0,13 & 2,76 & 4,18 & 3,4 \\
\hline 9 & 32,21 & 16,94 & 23,62 & 82,5 & 22,63 & 54,51 & 1,64 & 135,5 & 0 & 17,26 & 8,04 & 0,18 & 2,92 & 5,32 & 3,86 \\
\hline 10 & 28,81 & 14,27 & 20,48 & 90 & 35,86 & 66,79 & 1 & 149,9 & 0 & 17,45 & 7,3 & $-0,12$ & 2,41 & 4,14 & 2,71 \\
\hline 11 & 30,53 & 11,52 & 18,6 & 96,5 & 32,41 & 78,1 & 0,5 & 212,5 & 0 & 15,77 & 6,77 & 0 & 2,14 & 2,31 & 2,1 \\
\hline 12 & 31,82 & 13,2 & 21,04 & 95,2 & 22,3 & 65,16 & 1,03 & 106,2 & 0 & 17,62 & 8,15 & 0,19 & 2,49 & 3,81 & 3,11 \\
\hline 13 & 31,21 & 13,27 & 21,43 & 94,1 & 23,65 & 63,18 & 1,38 & 103,6 & 0 & 15,77 & 7,29 & 0,04 & 2,55 & 3,16 & 3,18 \\
\hline 14 & 32,09 & 14,55 & 22,1 & 89,9 & 15,84 & 61,11 & 1,47 & 110,3 & 0 & 15,57 & 6,13 & $-0,22$ & 2,66 & 2,81 & 3,19 \\
\hline 15 & 30,38 & 14,61 & 21,68 & 94,7 & 32,74 & 68,4 & 1,03 & 188,2 & 0 & 17,14 & 7,63 & 0,12 & 2,59 & 3,56 & 2,68 \\
\hline 16 & 29,74 & 13,93 & 21,64 & 97,3 & 28,44 & 66,44 & 0,71 & 148,8 & 0 & 17,15 & 7,79 & 0,18 & 2,59 & 3,12 & 2,71 \\
\hline 17 & 28,74 & 13,81 & 20,96 & 95,8 & 30,13 & 64,16 & 1,46 & 65,3 & 0 & 19,39 & 9,2 & 0,26 & 2,48 & 4,49 & 3,52 \\
\hline 18 & 29,35 & 13,74 & 21,27 & 88 & 27,23 & 58,74 & 1,67 & 51,11 & 0 & 20,04 & 9,16 & 0,1 & 2,53 & 4,72 & 3,87 \\
\hline 19 & 29,12 & 13,82 & 20,99 & 84,5 & 24,6 & 57,32 & 2,1 & 58,46 & 0 & 20,23 & 9,08 & 0,05 & 2,49 & 4,85 & 4,16 \\
\hline 20 & 28,4 & 13,68 & 20,72 & 85,7 & 29,6 & 60,33 & 2,03 & 58,49 & 0 & 19,6 & 8,85 & 0,05 & 2,44 & 3,87 & 3,87 \\
\hline 21 & 29,35 & 12,94 & 21,37 & 84,1 & 26,43 & 54,28 & 1,73 & 94,4 & 0 & 18,14 & 8,12 & 0,15 & 2,54 & 3,6 & 3,77 \\
\hline 22 & 29,74 & 15,14 & 22,3 & 85,9 & 28,77 & 56,85 & 1,54 & 90,5 & 0 & 14,43 & 6,26 & 0,08 & 2,69 & 2,78 & 3,13 \\
\hline 23 & 31,12 & 13,93 & 22,42 & 93,5 & 25,67 & 59,89 & 0,95 & 89,1 & 0 & 19,84 & 8,79 & 0,18 & 2,71 & 3,72 & 3,31 \\
\hline 24 & 31,02 & 14,27 & 22,61 & 90,9 & 23,98 & 54,57 & 1,44 & 79 & 0 & 20,89 & 8,79 & 0,06 & 2,74 & 3,86 & 3,86 \\
\hline 25 & 30,47 & 12,81 & 21,68 & 91,7 & 19,61 & 55,47 & 1,31 & 86,7 & 0 & 21,82 & 9,1 & 0,14 & 2,59 & 4,76 & 3,8 \\
\hline 26 & 29,36 & 12,67 & 20,56 & 94,5 & 28,43 & 61,67 & 1,4 & 113 & 0 & 21,66 & 9,14 & 0,25 & 2,42 & 4,56 & 3,53 \\
\hline 27 & 28,7 & 11,53 & 20,45 & 92 & 25,54 & 59,66 & 1,78 & 95 & 0 & 23,13 & 9,22 & 0,04 & 2,40 & 4,16 & 3,87 \\
\hline 28 & 29,89 & 12,73 & 21,04 & 94,4 & 23,06 & 57,34 & 1,66 & 66,97 & 0 & 23,08 & 10 & 0,36 & 2,49 & 5,32 & 4,12 \\
\hline 29 & 28,04 & 13,74 & 19,16 & 96,2 & 34,68 & 69,45 & 1,56 & 120,8 & 12,6 & 9,59 & 3,3 & $-0,12$ & 2,22 & 1,82 & 1,82 \\
\hline 30 & 24,37 & 16 & 20,02 & 96,2 & 57,35 & 78,6 & 0,71 & 154,5 & 1,3 & 12,19 & 5,57 & 0,2 & 2,34 & 1,27 & 1,76 \\
\hline 31 & 23,32 & 14,2 & 18,14 & 96,8 & 67,92 & 89,6 & 0,52 & 178,9 & 4,8 & 7,91 & 3,48 & 0,13 & 2,08 & 0,99 & 0,99 \\
\hline Total & 895,68 & 450,45 & 667,08 & 2975,6 & 1101 & 2150,4 & 40,52 & 3634 & 87,9 & 530,4 & 236 & 3,96 & 76,69 & 106 & 93,95 \\
\hline Média & 28,89 & 14,08 & 20,85 & 92,99 & 34,4 & 67,2 & 1,27 & 113,6 & 2,75 & 16,57 & 7,37 & 0,12 & 2,47 & 3,33 & 2,94 \\
\hline V.máx. & 32,54 & 16,94 & 23,62 & 97,4 & 78,1 & 91,3 & 2,1 & 221 & 39,4 & 23,13 & 10 & 0,45 & 2,92 & 5,32 & 4,16 \\
\hline V.mín & 20,33 & 11,52 & 17,71 & 82,5 & 15,84 & 54,28 & 0,5 & 51,11 & 0 & 5,58 & 2,57 & $-0,22$ & 2,03 & 0,82 & 0,82 \\
\hline
\end{tabular}


Anexo 3 - Dados meteorológicos do mês de setembro de 2002. Fazenda Areão, ESALQ, Piracicaba/SP.

\begin{tabular}{|c|c|c|c|c|c|c|c|c|c|c|c|c|c|c|c|}
\hline \multirow[t]{3}{*}{ Dia } & \multicolumn{2}{|c|}{ TEMPER. DO AR $\left({ }^{\circ} \mathrm{C}\right.$} & \multicolumn{4}{|c|}{ UMIDADE RELATIVA (\%) } & \multicolumn{2}{|c|}{ Vento } & \multirow{3}{*}{$\begin{array}{l}\text { Chuva } \\
(\mathrm{mm})\end{array}$} & \multirow[t]{3}{*}{$\mathrm{Qg}$} & \multirow[t]{2}{*}{$\mathrm{Rn}$} & \multirow[t]{3}{*}{ G } & \multirow{3}{*}{$\begin{array}{c}\text { es } \\
(\mathrm{kPa}) \\
\end{array}$} & \multirow{2}{*}{$\begin{array}{c}\text { ETo } \\
\text { (ECA) }\end{array}$} & \multirow{2}{*}{$\begin{array}{r}\text { ETo-PM } \\
\text { (FAO) }\end{array}$} \\
\hline & Máx. & Mín. & Méd. & Máx. & Mín. & Méd. & Veloc. & Direc. & & & & & & & \\
\hline & & $\left({ }^{\circ} \mathrm{C}\right)$ & & & $(\%)$ & & $(\mathrm{m} / \mathrm{s})$ & $\left(G^{\circ}\right)$ & & & $\left(\mathrm{MJ} \mathrm{m}^{-2} \mathrm{dia}^{-1}\right)$ & & & \multicolumn{2}{|c|}{$(\mathrm{mm})$} \\
\hline & 22,11 & 13,47 & 17,79 & 91,1 & 26 & 58,55 & 1,66 & 249,8 & 0,1 & 23,74 & 11 & 0,53 & 2,1 & 4,4 & 4,05 \\
\hline & 19,39 & 6,03 & 12,71 & 89,8 & 20,94 & 55,37 & 1,31 & 224 & 0 & 24,98 & 9,56 & $-0,14$ & 1,59 & 4,18 & 3,31 \\
\hline & 24,25 & 3,43 & 13,84 & 95,6 & 16,2 & 55,9 & 0,83 & 116,1 & 0 & 23,4 & 9,68 & 0,22 & 1,91 & 2,93 & 3,36 \\
\hline & 26,84 & 6,77 & 16,81 & 92,9 & 13,09 & 53 & 0,54 & 143,4 & 0 & 19,61 & 7,68 & $-0,03$ & 2,26 & 3,2 & 2,79 \\
\hline & 27,25 & 10,46 & 18,86 & 94,4 & 42,63 & 68,52 & 0,46 & 164,4 & 0 & 13,29 & 5,83 & 0,11 & 2,44 & 1,87 & 2,01 \\
\hline & 33,6 & 15,94 & 24,77 & 91,8 & 30,17 & 60,99 & 1,77 & 140 & 0 & 18,76 & 9,61 & 0,49 & 3,51 & 5,05 & 4,76 \\
\hline & 26,23 & 15,01 & 20,62 & 91,7 & 51,86 & 71,78 & 1,73 & 159,6 & 11,1 & 13,94 & 6,96 & 0,38 & 2,56 & 6,53 & 2,89 \\
\hline & 22,53 & 13,81 & 18,17 & 82,8 & 46,46 & 64,63 & 2,27 & 150,7 & 0 & 14,63 & 7,35 & 0,35 & 2,15 & 3,24 & 3,2 \\
\hline & 28,24 & 12,53 & 20,39 & 91,2 & 42,22 & 66,71 & 0,88 & 199,7 & 0 & 17,35 & 8,27 & 0,27 & 2,64 & 3,04 & 3,04 \\
\hline 10 & 30,37 & 13,67 & 22,02 & 94,5 & 37,11 & 65,81 & 0,81 & 204,6 & 0 & 21,3 & 10,2 & 0,42 & 2,95 & 3,65 & 3,68 \\
\hline 11 & 30,37 & 14,81 & 22,59 & 95,7 & 31,61 & 63,66 & 1,32 & 114,7 & 0 & 20,33 & 10,1 & 0,42 & 3,01 & 4,33 & 4,15 \\
\hline 12 & 32,08 & 15,56 & 23,82 & 83,7 & 22,84 & 53,27 & 1,92 & 135,6 & 0 & 21,99 & 10,9 & 0,44 & 3,27 & 5 & 5,39 \\
\hline 13 & 27,85 & 18,93 & 23,39 & 85,6 & 39,72 & 62,66 & 0,38 & 127,1 & 0 & 7,52 & 3,27 & 0,05 & 2,97 & 1,33 & 1,33 \\
\hline 14 & 27,45 & 17,81 & 22,63 & 92,4 & 49,44 & 70,92 & 1,09 & 194,4 & 1,4 & 10,48 & 4,78 & 0,05 & 2,85 & 2,5 & 2,12 \\
\hline 15 & 4 & 14,08 & 2 & 4 & 38,34 & 65,37 & 45 & 8 & 0 & 34 & 3 & 1 & 2,87 &, 05 & 4,1 \\
\hline & 23,74 & 16,41 & 20,08 & 91,8 & 61,92 & 76,86 & 1,23 & 129,4 & 0,8 & 8,94 & 3,43 & $-0,13$ & 2,4 & 2,04 & 1,51 \\
\hline 17 & 31,78 & 14,35 & 23,07 & 96,2 & 30,66 & 63,43 & 0,96 & 110,1 & 0,1 & 21,82 & 11,6 & 0,81 & 3,17 & 3,49 & 4,39 \\
\hline 18 & 31,54 & 16,67 & 24,11 & 93,7 & 32,73 & 63,22 & 0,88 & 134,4 & 10,3 & 17,81 & 9,01 & 0,42 & 3,27 & 3,3 & 3,57 \\
\hline 19 & 32,15 & 16,75 & 24,45 & 94,1 & 30,45 & 62,28 & 1,42 & 110,2 & 0 & 17,97 & 9,67 & 0,59 & 3,35 & 4,35 & 4,3 \\
\hline 20 & 25,24 & 18,89 & 22,07 & 95,7 & 53,35 & 74,53 & 1,54 & 122,7 & 23,9 & 4,93 & 2,12 & $-0,01$ & 2,7 & 1,2 & 1,46 \\
\hline 21 & 19,23 & 12,6 & 15,92 & 96,1 & 73,6 & 84,85 & 1,53 & 176,3 & 6,2 & 4,16 & 1,95 & 0 & 1,84 & 1,64 & 0,89 \\
\hline 22 & 19,53 & 11,66 & 15,6 & 92,3 & 57,29 & 74,8 & 0,86 & 145 & 0,5 & 10,35 & 4,49 & 0,01 & 1,82 & 2,04 & 1,53 \\
\hline 23 & 22,46 & 13,54 & 18 & 90,6 & 55,29 & 72,95 & 0,88 & 181,2 & 0 & 10,87 & 4,96 & 0,14 & 2,14 & 2,02 & 1,79 \\
\hline 24 & 20,28 & 13,75 & 17,02 & 90,5 & 57,93 & 74,22 & 2,15 & 168,3 & 0 & 9,17 & 4,19 & $-0,03$ & 1,98 & 2,45 & 1,95 \\
\hline 25 & 26,61 & 10,93 & 18,77 & 94,9 & 32,64 & 63,77 & 1,06 & 141,4 & 0 & 23,78 & 12,1 & 0,58 & 2,4 & 4,16 & 4,15 \\
\hline 26 & 27,54 & 10,8 & 19,17 & 96,2 & 26,42 & 61,31 & 0,98 & 154,9 & 0 & 23,9 & 11,9 & 0,59 & 2,49 & 4,72 & 4,19 \\
\hline 27 & 28,87 & 13,01 & 20,94 & 92,8 & 31,13 & 61,97 & 1,26 & 183,5 & 0 & 24,21 & 12,1 & 0,56 & 2,74 & 5,76 & 4,52 \\
\hline 28 & 30,38 & 12,66 & 21,52 & 94,9 & 26,88 & 60,89 & 0,72 & 151 & 0 & 23,76 & 12 & 0,6 & 2,9 & 4,31 & 4,22 \\
\hline 29 & 32,46 & 14,2 & 23,33 & 95,7 & 22,97 & 59,34 & 1,15 & 130,3 & 0 & 23,53 & 12,3 & 0,71 & 3,25 & 6,26 & 4,94 \\
\hline 30 & 34,17 & 17,02 & 25,6 & 80,1 & 20,54 & 50,32 & 1,71 & 138,8 & 0 & 21,73 & 11,1 & 0,55 & 3,66 & 5,52 & 5,57 \\
\hline Total & 814,08 & 405,55 & 609,82 & 2761,2 & 1122,4 & 1941,8 & 36,73 & 4665 & 54,4 & 519,1 & 248 & 9,34 & 79,2 & 108,6 & 99,14 \\
\hline Média & 27,14 & 13,52 & 20,33 & 92,04 & 37,41 & 64,73 & 1,22 & 155,5 & 1,81 & 17,3 & 8,28 & 0,31 & 2,64 & 3,62 & 3,3 \\
\hline V.máx. & 34,17 & 18,93 & 25,6 & 96,2 & 73,6 & 84,85 & 2,27 & 249,8 & 23,9 & 24,98 & 12,3 & 0,81 & 3,66 & 6,53 & 5,57 \\
\hline V.min. & 19,23 & 3,43 & 12,71 & 80,1 & 13,09 & 50,32 & 0,38 & 110,1 & 0 & 4,16 & 1,95 & $-0,14$ & 1,59 & 1,2 & 0,89 \\
\hline
\end{tabular}

ETo $($ TCA $)$ = Evapotranspiração de referência pelo método de Tanque "Classe A"; ETo (PM) = Evapotranspiração de referência pelo método de Penman_Monteith (FAO); Qg = Radiação Global; Rn = Radiação Liquida; $\mathrm{G}$ = Fluxo de calor no solo; es =pressão de saturação vapor. 
Anexo 4 - Dados meteorológicos do mês de outubro de 2002. Fazenda Areão, ESALQ, Piracicaba/SP.

\begin{tabular}{|c|c|c|c|c|c|c|c|c|c|c|c|c|c|c|c|}
\hline \multirow[t]{3}{*}{ Dia } & \multicolumn{3}{|c|}{ TEMPER. DO AR $\left({ }^{\circ} \mathrm{C}\right)$} & \multicolumn{3}{|c|}{ UMIDADE RELATIVA (\%) } & \multicolumn{2}{|c|}{ Vento } & \multirow{3}{*}{$\begin{array}{l}\text { Chuva } \\
(\mathrm{mm})\end{array}$} & \multirow[t]{3}{*}{$\mathrm{Qg}$} & \multirow[t]{2}{*}{$\mathrm{Rn}$} & \multirow[t]{3}{*}{$\bar{G}$} & \multirow[t]{2}{*}{ es } & \multirow{2}{*}{$\begin{array}{l}\text { ETo } \\
\text { (ECA) }\end{array}$} & \multirow{2}{*}{$\begin{array}{r}\text { ETo-PM } \\
(\mathrm{FAO})\end{array}$} \\
\hline & Máx. & Mín. & Méd. & Máx. & Mín. & Méd. & Veloc. & Direc. & & & & & & & \\
\hline & & $\left({ }^{\circ} \mathrm{C}\right)$ & & & $(\%)$ & & $(\mathrm{m} / \mathrm{s})$ & $\left(G^{\circ}\right)$ & & & $\left(\mathrm{MJ} \mathrm{m}^{-2} \mathrm{dia}^{-1}\right)$ & & $(\mathrm{kPa})$ & \multicolumn{2}{|c|}{$(\mathrm{mm})$} \\
\hline 1 & 23,91 & 18,21 & 21,06 & 92,4 & 51,34 & 71,87 & 1,42 & 137,2 & 3,1 & 7,41 & 2,85 & $-0,11$ & 2,53 & 2,55 & 1,61 \\
\hline 2 & 28,94 & 16,8 & 22,87 & 86 & 28,17 & 57,09 & 2,07 & 138,5 & 0 & 25,59 & 13,5 & 0,85 & 2,95 & 5,37 & 5,61 \\
\hline 3 & 31,3 & 13,27 & 22,29 & 95,8 & 37,53 & 66,67 & 0,89 & 163,8 & 0 & 20,61 & 10,8 & 0,71 & 3,05 & 4,54 & 3,94 \\
\hline 4 & 32,42 & 19,67 & 26,05 & 80,7 & 31,63 & 56,17 & 0,91 & 140,4 & 0 & 21,35 & 11 & 0,67 & 3,58 & 4,33 & 4,33 \\
\hline 5 & 34,47 & 17,55 & 26,01 & 91,7 & 22,74 & 57,22 & 1,52 & 106,8 & 0 & 23,19 & 11,6 & 0,53 & 3,73 & 5,6 & 5,36 \\
\hline 6 & 34,9 & 17,81 & 26,36 & 91,3 & 29,61 & 60,46 & 0,83 & 177,4 & 0 & 18,66 & 9,41 & 0,46 & 3,82 & 5,11 & 3,89 \\
\hline 7 & 34,79 & 19,08 & 26,94 & 86,7 & 23,97 & 55,34 & 1,5 & 129,7 & 0 & 24,52 & 13,1 & 0,81 & 3,88 & 5,81 & 5,78 \\
\hline \multicolumn{16}{|l|}{8} \\
\hline \multicolumn{16}{|l|}{9} \\
\hline 10 & 36,44 & 19,59 & 28,02 & 85,7 & 17,14 & 51,42 & 1,21 & 97,7 & 0 & 23,61 & 11,3 & 0,6 & 4,18 & 5,26 & 5,26 \\
\hline 11 & 37,47 & 18,46 & 27,96 & 90,1 & 15,52 & 52,81 & 0,97 & 126,1 & 0 & 24,35 & 11,8 & 0,71 & 4,28 & 6,35 & 5,19 \\
\hline 12 & 36,92 & 22,11 & 29,51 & 80,4 & 13,3 & 46,85 & 1,36 & 172,8 & 0 & 23,11 & 11,2 & 0,76 & 4,45 & 5,59 & 5,59 \\
\hline 13 & 37,15 & 18,39 & 27,77 & 84,3 & 17,41 & 50,86 & 1,46 & 138,8 & 0,8 & 22,75 & 10,8 & 0,55 & 4,22 & 5,89 & 5,52 \\
\hline 14 & 36,75 & 18,52 & 27,64 & 92,7 & 13,45 & 53,08 & 0,82 & 130 & 0 & 23,46 & 10,9 & 0,57 & 4,16 & 5,48 & 4,68 \\
\hline 15 & 36,95 & 18,3 & 27,36 & 85,5 & 21,58 & 46,42 & 1,38 & & 0 & 23,24 & 10,2 & & 4,18 & 3,34 & 5,12 \\
\hline 16 & 36,95 & 15,02 & 27,49 & 99 & 16,25 & 45,32 & 0,88 & & 0 & 23,87 & 10,8 & & 3,98 & 0 & 4,66 \\
\hline 17 & 36,95 & 21,54 & 24,92 & 87,1 & 46,2 & 68,08 & 3,05 & & 0 & 15,82 & 5,85 & & 4,41 & 0 & 4,81 \\
\hline 18 & 36,95 & 21,07 & 25,1 & 92 & 39,88 & 73,5 & 2,79 & & 0 & 18,17 & 7,98 & & 4,38 & 0 & 5,34 \\
\hline 19 & 36,95 & 19,68 & 26,04 & 96,6 & 42,89 & 67,03 & 1,45 & & 0 & 16,76 & 7,87 & & 4,27 & 0 & 3,89 \\
\hline 20 & 35,38 & 20,37 & 27,64 & 83,1 & 22,86 & 52,98 & 1,66 & 89,2 & 0 & 23,94 & 10,7 & 0,66 & 4,07 & 5,41 & 5,41 \\
\hline 21 & 36,52 & 19,77 & 28,15 & 89,1 & 19,27 & 54,19 & 2,35 & 202 & 8,3 & 22,29 & 10,6 & 0,9 & 4,21 & 3,56 & 6,27 \\
\hline 22 & 30,59 & 17,71 & 24,15 & 92,8 & 41,77 & 67,28 & 2,66 & 144,9 & 1,9 & 25,59 & 12,5 & 0,8 & 3,21 & 5,44 & 5,33 \\
\hline 23 & 28,06 & 15,97 & 22,02 & 79,4 & 41,74 & 60,57 & 2,78 & 154,2 & 0 & 28,53 & 13,2 & 0,73 & 2,8 & 6,09 & 5,5 \\
\hline 24 & 33,82 & 15,57 & 24,67 & 91,4 & 29,68 & 60,54 & 0,67 & 156,5 & 0 & 26,12 & 12,9 & 0,79 & 3,52 & 4,47 & 4,64 \\
\hline 25 & 34,78 & 18,71 & 26,75 & 92,8 & 26,5 & 59,65 & 1,16 & 154,8 & 6,6 & 18,6 & 9,22 & 0,47 & 3,86 & 5,47 & 4,22 \\
\hline 26 & 32,43 & 19,65 & 26,04 & 92,6 & 40,05 & 66,33 & 1,73 & 143,7 & 0,4 & 22,81 & 11,6 & 0,72 & 3,58 & 6,47 & 4,84 \\
\hline 27 & 32,23 & 18 & 25,12 & 89,2 & 22,66 & 55,93 & 1,43 & 166,4 & 0 & 25,93 & 12 & 0,58 & 3,44 & 7,47 & 5,17 \\
\hline 28 & 34,5 & 17,05 & 25,78 & 87,4 & 19,76 & 53,58 & 1,27 & 168,9 & 0 & 26,11 & 12,4 & 0,63 & 3,71 & 5,93 & 5,4 \\
\hline 29 & 35,93 & 18,83 & 27,38 & 93,9 & 24,78 & 59,34 & 1,08 & 145,9 & 21 & 26,52 & 14 & 1,07 & 4,05 & 5,64 & 5,64 \\
\hline 30 & 27,95 & 20,24 & 24,1 & 94,2 & 53,17 & 73,69 & 1,29 & 151,9 & 8,4 & 11,38 & 5,87 & 0,42 & 3,07 & 2,8 & 2,46 \\
\hline \multicolumn{16}{|l|}{31} \\
\hline Total & 952,38 & 516,94 & 725,13 & 2503,9 & 810,9 & 1644,2 & 42,58 & 3338 & 50,5 & 614,3 & 296 & 14,9 & 106 & 124 & 135,48 \\
\hline Média & 34,01 & 18,46 & 25,9 & 89,43 & 28,96 & 58,72 & 1,52 & 145,1 & 1,8 & 21,94 & 10,6 & 0,65 & 3,77 & 4,43 & 4,84 \\
\hline V.máx. & 37,47 & 22,11 & 29,51 & 99 & 53,17 & 73,69 & 3,05 & 202 & 21 & 28,53 & 14 & 1,07 & 4,45 & 7,47 & 6,27 \\
\hline V.min. & 23,91 & 13,27 & 21,06 & 79,4 & 13,3 & 45,32 & 0,67 & 89,2 & 0 & 7,41 & 2,85 & $-0,11$ & 2,53 & 0 & 1,61 \\
\hline
\end{tabular}

ETo $($ TCA $)$ = Evapotranspiração de referência pelo método de Tanque "Classe A"; ETo (PMM) =Evapotranspiração de referência pelo método de

Penman_Monteith (FAO); $\mathrm{Qg}=$ Radiação Global; $\mathrm{Rn}=$ Radiação Liquida; $\mathrm{G}=$ Fluxo de calor no solo; es = pressão de saturação vapor 
Anexo 5 - Dados meteorológicos do mês de novembro de 2002. Fazenda Areão, ESALQ, Piracicaba/SP.

\begin{tabular}{|c|c|c|c|c|c|c|c|c|c|c|c|c|c|c|c|}
\hline \multirow[t]{3}{*}{ Dia } & \multicolumn{3}{|c|}{ TEMPER. DO AR $\left({ }^{\circ} \mathrm{C}\right)$} & \multicolumn{3}{|c|}{ UMIDADE RELATIVA (\%) } & \multicolumn{2}{|c|}{ Vento } & \multirow{3}{*}{$\begin{array}{c}\text { Chuva } \\
(\mathrm{mm})\end{array}$} & \multirow[t]{3}{*}{$\mathrm{Qg}$} & $\overline{\mathrm{Rn}}$ & \multirow[t]{3}{*}{$\bar{G}$} & \multirow{3}{*}{$\begin{array}{c}\mathrm{es} \\
(\mathrm{kPa})\end{array}$} & \multirow{2}{*}{$\begin{array}{c}\text { ETo } \\
(\mathrm{ECA})\end{array}$} & \multirow{2}{*}{$\begin{array}{r}\text { ETo-PM } \\
(\mathrm{FAO})\end{array}$} \\
\hline & Máx. & Mín. & Méd. & Máx. & Mín. & Méd. & Veloc. & Direc. & & & \multirow[b]{2}{*}{$\left(\mathrm{MJ} \mathrm{m}^{-2} \mathrm{dia}^{-1}\right)$} & & & & \\
\hline & & $\left({ }^{\circ} \mathrm{C}\right)$ & & & $(\%)$ & & $(\mathrm{m} / \mathrm{s})$ & $\left(G^{\circ}\right)$ & & & & & & \multicolumn{2}{|c|}{$(\mathrm{mm})$} \\
\hline 1 & 17,78 & 30,37 & 24,1 & 90,8 & 32,79 & 61,8 & 1,45 & 197,1 & 0 & 25,51 & 12,5 & 0,63 & 3,18 & 6,45 & 4,92 \\
\hline 2 & 31,2 & 16,84 & 37,61 & 85,2 & 24,39 & 54,79 & 1,91 & 128,4 & 0 & 29,3 & 13,6 & 0,74 & 10,2 & 6,42 & 5,45 \\
\hline 3 & 33,47 & 15,9 & 24,69 & 92 & 15,98 & 53,99 & 0,98 & 112,6 & 0 & 30,09 & 14,6 & 0,85 & 3,49 & 6,32 & 5,65 \\
\hline 4 & 29,82 & 18,52 & 24,17 & 91,2 & 38,7 & 64,95 & 1,76 & 144,2 & 0,1 & 14,07 & 6,34 & 0,2 & 3,17 & 3,21 & 3,31 \\
\hline 5 & 24,36 & 17,92 & 21,14 & 88,2 & 54,67 & 71,44 & 2,88 & 160,7 & 0,6 & 9,93 & 4,76 & 0,14 & 2,55 & 4,07 & 2,69 \\
\hline 6 & 23,08 & 14,56 & 18,82 & 77,1 & 41,24 & 59,17 & 3,6 & 151,6 & 0 & 18,45 & 8,75 & 0,38 & 2,24 & 5,19 & 4,34 \\
\hline 7 & 26,49 & 13,31 & 19,9 & 82,8 & 33,32 & 58,06 & 2,78 & 152,9 & 0 & 28,15 & 13,5 & 0,61 & 2,49 & 5,56 & 5,56 \\
\hline 8 & 28,38 & 14,64 & 21,51 & 79,1 & 25,31 & 52,21 & 1,9 & 125,3 & 0 & 29,19 & 14 & 0,74 & 2,77 & 5,71 & 5,71 \\
\hline 9 & 33,97 & 13,1 & 23,54 & 92,4 & 21,1 & 56,75 & 1,12 & 130,8 & 0 & 29,59 & 14,9 & 1,01 & 3,41 & 5,89 & 5,83 \\
\hline 10 & 34,63 & 19,71 & 27,17 & 93,3 & 30,34 & 61,82 & 2,1 & 157,7 & 5,5 & 18,27 & 9,29 & 0,54 & 3,9 & 4,99 & 4,99 \\
\hline 11 & 34,3 & 16,41 & 25,35 & 92,85 & 25,72 & 59,29 & 0,95 & 144,3 & 2,1 & 14,9 & 12,1 & 0,77 & 3,64 & 1,75 & 2,18 \\
\hline 12 & 27,41 & 19,52 & 23,47 & 91,3 & 58,16 & 74,73 & 1,54 & 146,1 & 0,4 & 17,08 & 9,01 & 0,65 & 2,96 & 0,35 & 3,31 \\
\hline 13 & 26,02 & 17,63 & 21,83 & 92,1 & 63,39 & 77,75 & 1,88 & 156,3 & 6,3 & 9,58 & 4,57 & 0,17 & 2,69 & 2,09 & 2,09 \\
\hline 14 & 30,09 & 17,17 & 23,63 & 94,8 & 44,26 & 69,53 & 1,38 & 135,1 & 27,9 & 18,95 & 10,5 & 0,89 & 3,11 & 4,03 & 4,03 \\
\hline 15 & 31,08 & 18,46 & 24,77 & 95,1 & 44,19 & 69,65 & 1,8 & 117,7 & 10,6 & 23,66 & 13 & 1,05 & 3,32 & 5 & 5 \\
\hline 16 & 33,28 & 18,86 & 26,07 & 93,7 & 34,54 & 64,12 & 1,38 & 127,3 & 0 & 24,08 & 13,1 & 0,97 & 3,64 & 3,54 & 5,21 \\
\hline 17 & 33,12 & 18,86 & 25,99 & 94,3 & 36,92 & 65,61 & 1,08 & 130,9 & 0 & 22,17 & 12 & 0,91 & 3,62 & 4,37 & 4,6 \\
\hline 18 & 34,97 & 19,39 & 27,18 & 95,2 & 33,32 & 64,26 & 1,88 & 136,8 & 26,7 & 21,35 & 11,8 & 0,92 & 3,93 & 5,42 & 5,42 \\
\hline 19 & 30,54 & 19,05 & 24,8 & 95,2 & 45,22 & 70,21 & 1,16 & 161,9 & 0,4 & 25,52 & 13,6 & 1,03 & 3,29 & 6,42 & 4,78 \\
\hline 20 & 32,75 & 19,7 & 26,23 & 92,7 & 37,67 & 65,19 & 1,07 & 126,7 & 0 & 27,12 & 14,2 & 1,02 & 3,63 & 7,42 & 5,22 \\
\hline 21 & 34,43 & 21,03 & 27,73 & 93,5 & 32,57 & 63,04 & 1,64 & 145,3 & 0 & 26,06 & 13,9 & 1,09 & 3,97 & 8,42 & 5,8 \\
\hline 22 & 30,43 & 21,5 & 25,97 & 79,4 & 45,7 & 62,55 & 3,25 & 165,7 & 0 & 22,59 & 11,8 & 0,83 & 3,46 & 9,42 & 5,58 \\
\hline 23 & 31,94 & 20,59 & 26,27 & 84,2 & 41,36 & 62,78 & 1,24 & 130,2 & 0 & 24,94 & 13,4 & 1,01 & 3,58 & 5,06 & 5,06 \\
\hline 24 & 32,06 & 21,73 & 26,9 & 90,1 & 44,8 & 67,45 & 0,9 & 125,5 & 0 & 21,28 & 11,3 & 0,82 & 3,69 & 4,13 & 4,13 \\
\hline 25 & 33,25 & 23,1 & 28,75 & 84,8 & 37,03 & 60,91 & 1,36 & 143,1 & 0 & 20,62 & 10,7 & 0,78 & 3,96 & 4,57 & 4,57 \\
\hline 26 & 24,9 & 20,21 & 22,56 & 95,4 & 72,7 & 84,05 & 1,43 & 92,3 & 35 & 5,75 & 2,5 & 0,03 & 2,76 & 1,16 & 1,16 \\
\hline 27 & 32,36 & 21,06 & 26,71 & 93,5 & 45,22 & 69,36 & 0,88 & 111,5 & 27,3 & 21,54 & 11,8 & 0,92 & 3,67 & 4,26 & 4,26 \\
\hline 28 & 32,48 & 19,44 & 25,96 & 95,6 & 40,29 & 67,94 & 1,12 & 133 & 45,4 & 22,42 & 12,3 & 1,04 & 3,57 & 4,6 & 4,6 \\
\hline 29 & 32,25 & 20,14 & 26,19 & 94,7 & 41,24 & 67,97 & 1,29 & 147,8 & 0 & 17,02 & 9,06 & 0,7 & 3,59 & 5,6 & 3,79 \\
\hline 30 & & & & & & & & & & & & & & & \\
\hline Total & 863,06 & 518,35 & 728,96 & 2529,8 & 1109,3 & 1881,3 & 47,72 & 3842 & 188,3 & 619,2 & 323 & 21,5 & 103 & 141,4 & 129,26 \\
\hline Média & 30,82 & 18,51 & 25,14 & 90,35 & 39,62 & 64,87 & 1,65 & 137,2 & 6,49 & 21,35 & 11,1 & 0,74 & 3,57 & 4,88 & 4,46 \\
\hline V.máx. & 34,97 & 23,1 & 37,61 & 95,6 & 72,7 & 84,05 & 3,6 & 165,7 & 45,4 & 30,09 & 14,9 & 1,09 & 10,2 & 9,42 & 5,83 \\
\hline V.min. & 23,08 & 13,1 & 18,82 & 77,1 & 15,98 & 52,21 & 0,88 & 92,3 & 0 & 5,75 & 2,5 & 0,03 & 2,24 & 0,35 & 1,16 \\
\hline
\end{tabular}

ETo $($ TCA ) = Evapotranspiração de referência pelo método de Tanque "Classe A"; ETo (PM) = Evapotranspiração de referência pelo método de

Penman_Monteith (FAO); Qg = Radiação Global; Rn = Radiação Liquida; $\mathrm{G}$ = Fluxo de calor no solo; es = pressão de saturação vapor 
Anexo 6 - Transpiração diária (L/planta), medida através do método de dissipação de calor no período entre 17 de agosto (229) e 16 de novembro (320) de 2002.

\begin{tabular}{|c|c|c|c|c|c|c|c|c|c|c|c|c|c|}
\hline Dia juliano & $\begin{array}{l}\text { Planta } 1 \\
\end{array}$ & $\begin{array}{l}\text { Planta } 2 \\
\end{array}$ & $\begin{array}{l}\text { Planta } 3 \\
\end{array}$ & $\begin{array}{l}\text { Planta } 4 \\
\end{array}$ & Planta 5 & Planta 6 & Dia juliano & $\begin{array}{l}\text { Planta } 1 \\
\end{array}$ & $\begin{array}{l}\text { Planta 2 } \\
\end{array}$ & Planta 3 & $\begin{array}{l}\text { Planta } 4 \\
\end{array}$ & Planta 5 & Planta 6 \\
\hline 229 & 3,57 & 4,37 & & 1,27 & 2,66 & 1,72 & 280 & 6,41 & 7,15 & 3,01 & 2,39 & & 3,05 \\
\hline 230 & 4,26 & 4,76 & & 1,41 & 2,92 & 1,31 & 281 & 6,55 & 6,85 & 4,68 & 2,31 & & 4,65 \\
\hline 231 & 3,65 & 4,53 & & 1,30 & 3,39 & 1,58 & 282 & 6,62 & 5,36 & 4,83 & 3,38 & & 4,70 \\
\hline 232 & 3,68 & 5,18 & & 1,19 & 4,33 & 2,00 & 283 & 7,24 & 6,21 & 6,88 & 3,45 & & 5,93 \\
\hline 233 & 3,90 & 5,86 & & 1,32 & 4,39 & 2,10 & 284 & 6,75 & 5,24 & 6,07 & 3,27 & & 5,62 \\
\hline 234 & 3,28 & 4,69 & & 1,28 & 3,19 & 2,11 & 285 & 6,92 & 5,46 & 6,38 & 3,65 & & 5,27 \\
\hline 235 & 3,42 & 5,47 & & 1,08 & 2,79 & 2,26 & 286 & 6,32 & 5,21 & 5,12 & 3,60 & & 4,12 \\
\hline 236 & 3,85 & 4,77 & & 0,80 & 2,90 & 2,18 & 287 & 6,25 & 4,87 & 4,86 & 3,40 & & 5,30 \\
\hline 237 & 3,65 & 5,03 & & 1,14 & 2,97 & 2,12 & 288 & 7,35 & 5,35 & 5,36 & 3,85 & & 4,57 \\
\hline 238 & 3,63 & 5,90 & & 0,67 & 3,09 & 2,05 & 289 & 7,33 & 5,24 & 5,12 & 3,33 & & 4,37 \\
\hline 239 & 3,97 & 5,64 & 2,63 & 1,75 & 4,57 & 2,46 & 290 & 6,45 & 4,43 & 5,26 & 2,93 & & 2,95 \\
\hline 240 & 4,13 & 5,31 & 1,91 & 1,70 & 4,23 & 2,29 & 291 & 7,36 & 4,22 & 4,38 & 2,90 & & 2,91 \\
\hline 241 & 2,24 & 3,39 & 2,20 & 0,86 & 1,74 & 1,51 & 292 & 8,25 & 5,53 & 4,29 & 3,35 & & 4,24 \\
\hline 242 & 2,68 & 3,00 & 2,29 & 1,02 & 2,21 & 1,89 & 293 & 8,26 & 5,80 & 4,69 & 2,61 & & 4,53 \\
\hline 243 & 1,83 & 2,66 & 1,81 & 0,48 & 1,05 & 1,07 & 294 & 7,34 & 5,21 & 3,86 & 1,51 & & 4,03 \\
\hline 244 & 4,56 & 4,25 & 3,32 & 0,39 & 4,05 & 2,84 & 295 & 8,15 & 5,59 & 3,97 & 2,80 & & 4,07 \\
\hline 245 & 4,11 & 4,92 & 3,60 & 0,66 & 4,36 & 3,47 & 296 & 5,51 & 2,89 & 4,34 & 2,30 & & 3,54 \\
\hline 246 & 3,34 & 5,17 & 2,88 & 1,07 & 4,35 & 2,38 & 297 & 8,21 & 7,13 & 6,04 & & & 2,22 \\
\hline 247 & 4,43 & 4,47 & 2,58 & 0,93 & 3,42 & 2,26 & 298 & 7,87 & 6,86 & 5,08 & & & 4,93 \\
\hline 248 & 3,84 & 4,60 & 1,96 & 0,69 & 2,28 & 1,93 & 299 & 7,56 & 6,53 & 4,38 & & & 4,96 \\
\hline 249 & 5,26 & 5,58 & 2,67 & 0,57 & 5,11 & 2,47 & 300 & 8,12 & 7,13 & 6,85 & & & 5,87 \\
\hline 250 & 4,79 & 3,58 & 4,36 & 1,35 & 1,82 & 1,24 & 301 & 6,25 & 5,36 & 4,39 & & & 4,34 \\
\hline 251 & 3,48 & 3,76 & 2,70 & 1,89 & 4,67 & 2,99 & 302 & 7,24 & 6,20 & 4,64 & & & 4,57 \\
\hline 252 & 4,21 & 4,80 & 2,80 & 0,78 & 3,48 & 2,43 & 303 & 3,31 & 3,13 & 2,57 & & & $\begin{array}{l}1,76 \\
\end{array}$ \\
\hline 253 & 4,84 & 4,24 & 2,77 & 0,31 & 2,35 & 2,48 & 304 & 5,25 & 4,99 & 4,57 & & & \\
\hline 254 & 5,16 & 3,66 & 2,72 & 0,67 & 2,54 & 2,35 & 305 & 7,56 & 6,56 & 6,15 & & & \\
\hline 255 & 8,35 & 5,03 & 2,94 & 0,60 & 6,02 & 3,92 & 306 & 7,86 & 6,26 & 5,85 & & & \\
\hline 256 & 2,80 & 2,17 & 1,85 & 0,69 & 1,59 & 1,36 & 307 & 8,25 & 7,25 & 6,68 & & & \\
\hline 257 & 3,48 & 4,06 & 2,97 & 1,30 & 3,81 & 1,80 & 308 & 7,83 & 6,66 & 6,32 & & & \\
\hline 258 & 5,26 & 2,96 & 2,41 & 0,74 & 4,16 & 1,54 & 309 & 4,57 & 4,41 & 4,64 & & & \\
\hline 259 & 1,97 & 2,24 & 1,63 & 0,82 & 2,53 & 1,22 & 310 & 5,54 & 5,13 & 4,35 & & & \\
\hline 260 & 6,41 & 4,58 & 1,76 & 1,02 & 5,46 & 3,00 & 311 & 8,13 & 6,95 & 4,56 & & & \\
\hline 261 & & & & & & & 312 & 8,25 & 6,97 & 4,01 & & & \\
\hline 262 & & & & & & & 313 & 8,56 & 6,34 & 2,79 & & & \\
\hline 263 & 1,11 & 0,96 & 1,01 & 0,40 & & 0,87 & 314 & 7,49 & 7,12 & 4,40 & & & \\
\hline 264 & 1,62 & 2,07 & 1,11 & 0,83 & & 1,14 & 315 & 3,58 & & 4,65 & & & \\
\hline 265 & 2,60 & 3,06 & 1,59 & 1,00 & & 2,12 & 316 & 4,56 & 4,02 & 4,01 & & & \\
\hline 266 & & & & & & & 317 & 4,56 & 4,13 & 3,69 & & & \\
\hline 267 & & & & & & & 318 & 5,76 & 4,70 & 4,57 & & & \\
\hline 268 & & & & & & & 319 & 8,04 & 7,33 & 4,58 & & & \\
\hline 269 & 4,86 & 2,70 & 3,64 & 1,56 & & 2,69 & 320 & 8,43 & 7,65 & 5,66 & & & \\
\hline 270 & 5,59 & 6,74 & 4,57 & 2,25 & & 3,14 & 321 & 7,87 & 7,30 & 5,45 & & & \\
\hline 271 & 4,67 & 5,05 & 3,77 & 1,69 & & 2,49 & 322 & 8,33 & 8,29 & 6,36 & & & \\
\hline 272 & 6,90 & 4,51 & 4,88 & 1,83 & & 3,31 & 323 & 7,37 & 7,24 & 6,28 & & & \\
\hline 273 & 8,35 & 6,42 & 7,86 & 2,47 & & 4,76 & 324 & 9,87 & 8,13 & 6,86 & & & \\
\hline 274 & 2,58 & 4,44 & 1,83 & 1,14 & & 1,51 & 325 & 8,88 & 7,85 & 7,44 & & & \\
\hline 275 & 5,79 & 7,11 & 5,46 & 1,92 & & 3,95 & 326 & 6,68 & 6,02 & 5,97 & & & \\
\hline 276 & 4,87 & 6,84 & 4,93 & 2,22 & & 3,57 & 327 & 6,66 & 5,79 & 5,19 & & & \\
\hline 277 & 5,59 & 6,37 & 5,06 & 2,47 & & 4,39 & 328 & 5,91 & 4,87 & 6,73 & & & \\
\hline 278 & 6,32 & 7,29 & 5,23 & 2,29 & & 4,67 & 329 & 8,40 & 7,26 & 6,49 & & & \\
\hline 279 & 6,02 & 6,85 & 4,26 & 1,12 & & 3,60 & 330 & 1,84 & 1,74 & 1,83 & & & \\
\hline
\end{tabular}


Anexo 7 - Amplitude diária de contração do caule (ADC) e transpiração relativa da planta (TRR) no pomar jovem.

\begin{tabular}{|c|c|c|c|c|c|c|c|c|c|c|c|c|c|c|c|c|c|c|c|c|c|c|c|}
\hline \multirow{2}{*}{$\frac{\text { Dia Juliano }}{229}$} & \multicolumn{2}{|c|}{$\begin{array}{c}\text { Planta } 1 \\
\text { ADC TRR }\end{array}$} & \multicolumn{2}{|c|}{$\begin{array}{c}\text { Planta } 2 \\
\text { ADC TRR }\end{array}$} & \multicolumn{2}{|c|}{$\begin{array}{c}\text { Planta } 3 \\
\text { ADC TRR }\end{array}$} & \multicolumn{2}{|c|}{\begin{tabular}{c}
\multicolumn{2}{c}{ Planta 4} \\
ADC $\quad$ TRR \\
\end{tabular}} & \multicolumn{2}{|c|}{\begin{tabular}{c}
\multicolumn{2}{c}{ Planta 5} \\
ADC TRR
\end{tabular}} & \multicolumn{2}{|c|}{\begin{tabular}{c}
\multicolumn{2}{c|}{ Planta 6} \\
ADC $\quad$ TRR \\
\end{tabular}} & \multirow{2}{*}{ Dia Juliano } & \multirow{2}{*}{\begin{tabular}{cc}
\multicolumn{2}{c}{ Planta 1} \\
ADC & TRR \\
\end{tabular}} & \multicolumn{2}{|c|}{$\begin{array}{l}\text { Planta } 2 \\
\text { ADC TRR }\end{array}$} & \multicolumn{2}{|c|}{ Planta 3} & $\begin{array}{l}\text { Plant } \\
\text { ADC }\end{array}$ & $\begin{array}{l}\text { ta } 4 \\
\text { TRR }\end{array}$ & $\begin{array}{l}\text { Planta } 5 \\
\text { ADC } \text { TRR }^{2}\end{array}$ & $\begin{array}{l}\text { Plant } \\
\text { ADC }\end{array}$ & $\begin{array}{l}\text { TR } 6 \\
\text { TRR }\end{array}$ \\
\hline & 0,26 & 0,79 & 0,202 & 1,00 & & & 0,13 & 1,00 & 0,06 & 0,78 & 0,1 & 0,93 & & & 0,22 & 1,00 & 0,36 & 0,54 & 0,1 & 1,00 & & 0,3 & 0,80 \\
\hline 230 & 0,35 & 0,86 & 0,186 & 1,00 & & & 0,09 & 0,95 & 0,05 & 0,72 & 0,06 & 0,59 & 281 & & 0,19 & 1,00 & 0,34 & 0,82 & 0,07 & 1,00 & & 0,28 & 1,00 \\
\hline 231 & 0,37 & 0,77 & 0,203 & 1,00 & & & 0,08 & 1,00 & 0,04 & 0,98 & 0,09 & 0,83 & 282 & & 0,22 & 0,87 & 0,33 & 0,84 & 0,08 & 1,00 & & 0,36 & 1,00 \\
\hline 232 & 0,38 & 0,68 & 0,21 & 1,00 & & & 0,12 & 0,93 & 0,05 & 1,00 & 0,1 & 1,00 & 283 & & 0,19 & 0,93 & 0,37 & 1,00 & 0,08 & 1,00 & & 0,4 & 1,00 \\
\hline 233 & 0,37 & 0,64 & 0,21 & 1,00 & & & 0,09 & 0,97 & 0,06 & 1,00 & 0,11 & 1,00 & 284 & & 0,2 & 0,84 & 0,4 & 1,00 & 0,07 & 1,00 & & 0,45 & 1,00 \\
\hline 234 & 0,4 & 0,67 & 0,21 & 1,00 & & & 0,09 & 1,00 & 0,06 & 1,00 & 0,1 & 1,00 & 285 & & 0,21 & 0,85 & 0,36 & 1,00 & 0,06 & 1,00 & & 0,44 & 1,00 \\
\hline 235 & 0,4 & 0,60 & 0,24 & 1,00 & & & 0,13 & 0,91 & 0,05 & 0,88 & 0,19 & 1,00 & 286 & & 0,21 & 0,89 & 0,38 & 0,94 & 0,11 & 1,00 & & 0,45 & 1,00 \\
\hline 236 & 0,4 & 0,77 & 0,25 & 1,00 & & & 0,11 & 0,60 & 0,04 & 0,81 & 0,13 & 1,00 & 287 & & 0,22 & 0,84 & & 0,90 & 0,15 & 1,00 & & 0,5 & 1,00 \\
\hline 237 & 0,55 & 0,70 & 0,26 & 1,00 & & & 0,12 & 0,90 & 0,05 & 0,88 & 0,14 & 1,00 & 288 & & 0,2 & 0,79 & 0,34 & 0,85 & 0,05 & 1,00 & & 0,4 & 1,00 \\
\hline 238 & 0,45 & 0,59 & 0,27 & 1,00 & & & 0,21 & 0,54 & 0,05 & 0,92 & 0,22 & 1,00 & 289 & & 0,19 & 0,78 & 0,31 & 0,82 & 0,13 & 1,00 & & 0,44 & 0,98 \\
\hline 239 & 0,41 & 0,67 & 0,27 & 1,00 & 0,23 & 0,69 & 0,14 & 1,00 & 0,07 & 1,00 & 0,16 & 1,00 & 290 & & 0,22 & 0,75 & 0,32 & 0,95 & 0,18 & 1,00 & & 0,45 & 0,75 \\
\hline 240 & 0,41 & 0,74 & 0,3 & 1,00 & 0,25 & 0,48 & 0,13 & 1,00 & 0,09 & 1,00 & 0,19 & 1,00 & 291 & & 0,23 & 0,62 & 0,4 & 0,70 & 0,11 & 1,00 & & 0,47 & 0,65 \\
\hline 241 & 0,3 & 0,63 & 0,29 & 1,00 & 0,18 & 1,00 & 0,13 & 1,00 & 0,09 & 0,85 & 0,18 & 1,00 & 292 & & 0,2 & 0,73 & 0,37 & 0,61 & 0,18 & 1,00 & & 0,4 & 0,84 \\
\hline 242 & 0,3 & 0,85 & 0,22 & 1,00 & 0,09 & 0,90 & 0,08 & 1,00 & 0,09 & 0,91 & 0,15 & 1,00 & 293 & & 0,22 & 0,77 & 0,37 & 0,67 & 0,13 & 1,00 & & 0,4 & 0,89 \\
\hline 243 & 0,14 & 0,66 & 0,15 & 1,00 & 0,12 & 1,00 & 0,08 & 0,76 & 0,08 & 0,63 & 0,11 & 1,00 & 294 & & 0,2 & 0,77 & 0,34 & 0,62 & 0,19 & 0,65 & & 0,41 & 0,89 \\
\hline 244 & 0,24 & 1,00 & 0,21 & 0,98 & 0,17 & 0,77 & 0,12 & 0,25 & 0,1 & 0,98 & 0,08 & 1,00 & 295 & & 0,2 & 0,75 & 0,33 & 0,57 & 0,19 & 1,00 & & 0,4 & 0,80 \\
\hline 245 & 0,15 & 0,79 & 0,09 & 1,00 & 0,09 & 0,93 & 0,19 & 0,47 & 0,02 & 1,00 & 0,05 & 1,00 & 296 & & 0,21 & 0,57 & 0,3 & 0,93 & 0,12 & 1,00 & & 0,38 & 1,00 \\
\hline 246 & 0,15 & 0,61 & 0,11 & 1,00 & 0,13 & 0,92 & 0,17 & 0,94 & 0,05 & 1,00 & 0,11 & 1,00 & 297 & & 0,27 & 0,95 & 0,31 & 0,87 & & & & 0,39 & 0,43 \\
\hline 247 & 0,23 & 0,94 & 0,18 & 1,00 & 0,16 & 0,62 & 0,17 & 0,61 & 0,05 & 0,86 & 0,09 & 0,94 & 298 & & 0,28 & 0,95 & 0,34 & 0,77 & & & & 0,43 & 1,00 \\
\hline 248 & 0,15 & 0,79 & 0,13 & 1,00 & 0,12 & 0,54 & 0,11 & 0,53 & 0,06 & 0,66 & 0,11 & 0,92 & 299 & & 0,26 & 0,94 & 0,35 & 0,69 & & & & 0,45 & 1,00 \\
\hline 249 & 0,32 & 0,89 & 0,26 & 1,00 & 0,22 & 0,54 & 0,13 & 0,32 & 0,08 & 1,00 & 0,14 & 0,86 & 300 & & 0,26 & 0,96 & 0,3 & 1,00 & & & & 0,44 & 1,00 \\
\hline 250 & 0,21 & 1,00 & 0,22 & 0,79 & 0,16 & 0,97 & 0,08 & 0,83 & 0,08 & 0,43 & 0,2 & 0,47 & 301 & & 0,32 & 0,94 & 0,27 & 0,84 & & & & 0,45 & 1,00 \\
\hline 251 & 0,14 & 0,88 & 0,1 & 1,00 & 0,11 & 0,83 & 0,1 & 1,00 & 0,07 & 1,00 & 0,09 & 1,00 & 302 & & 0,27 & 0,94 & 0,26 & 0,77 & & & & 0,41 & 0,98 \\
\hline 252 & 0,18 & 0,83 & 0,11 & 1,00 & 0,13 & 0,71 & 0,19 & 0,55 & 0,06 & 0,94 & 0,17 & 1,00 & 303 & & 0,22 & 1,00 & 0,21 & 0,93 & & & & 0,33 & 0,84 \\
\hline 253 & 0,14 & 1,00 & 0,13 & 0,93 & 0,17 & 0,62 & 0,07 & 0,19 & 0,06 & 0,55 & 0,21 & 0,93 & 304 & & 0,13 & 1,00 & 0,12 & 1,00 & & & & & \\
\hline 254 & 0,22 & 1,00 & 0,16 & 0,75 & 0,22 & 0,57 & 0,08 & 0,39 & 0,08 & 0,56 & 0,27 & 0,82 & 305 & & 0,13 & 0,95 & 0,11 & 0,98 & & & & & \\
\hline 255 & 0,32 & 1,00 & 0,19 & 0,64 & 0,25 & 0,38 & 0,09 & 0,21 & 0,08 & 0,83 & 0,3 & 0,84 & 306 & & 0,18 & 0,88 & 0,15 & 0,90 & & & & & \\
\hline 256 & 0,21 & 1,00 & 0,12 & 0,82 & 0,17 & 0,72 & 0,08 & 0,73 & 0,07 & 0,65 & 0,24 & 0,87 & 307 & & 0,23 & 0,97 & 0,2 & 0,98 & & & & & \\
\hline 257 & 0,19 & 0,81 & 0,15 & 1,00 & 0,2 & 0,93 & 0,36 & 1,00 & 0,1 & 1,00 & 0,33 & 0,92 & 308 & & 0,21 & 0,94 & 0,21 & 0,98 & & & & & \\
\hline 258 & 0,23 & 1,00 & 0,15 & 0,60 & 0,2 & 0,50 & 0,07 & 0,42 & 0,06 & 0,92 & 0,32 & 0,52 & 309 & & 0,27 & 1,00 & 0,3 & 1,00 & & & & & \\
\hline 259 & 0,14 & 0,83 & 0,1 & 1,00 & 0,14 & 0,90 & 0,32 & 1,00 & 0,06 & 1,00 & 0,22 & 1,00 & 310 & & 0,34 & 1,00 & 0,34 & 0,96 & & & & & \\
\hline 260 & 0,22 & 1,00 & 0,14 & 0,76 & 0,23 & 0,30 & 0,12 & 0,48 & 0,08 & 0,99 & 0,25 & 0,83 & 311 & & 0,22 & 0,94 & 0,196 & 0,69 & & & & & \\
\hline 261 & & & & & & & & & & & & & 312 & & 0,2 & 0,93 & 0,104 & 0,60 & & & & & \\
\hline 262 & & & & & & & & & & & & & 313 & & 0,17 & 0,82 & 0,171 & 0,40 & & & & & \\
\hline 263 & & & 0,11 & 0,92 & 0,14 & 1,00 & 0 & 1,00 & & & 0,12 & 1,00 & 314 & & 0,19 & 1,00 & 0,118 & 0,72 & & & & & \\
\hline 264 & & & 0,11 & 1,00 & 0,15 & 0,76 & 0 & 1,00 & & & 0,21 & 1,00 & 315 & & & & & & & & & & \\
\hline 265 & & & 0,05 & 1,00 & 0,13 & 0,68 & 0 & 1,00 & & & 0,1 & 1,00 & 316 & & 0,26 & 0,98 & 0,211 & 1,00 & & & & & \\
\hline 266 & & & & & & & & & & & & & 317 & & 0,22 & 1,00 & 0,299 & 1,00 & & & & & \\
\hline 267 & & & & & & & & & & & & & 318 & & 0,2 & 0,91 & 0,314 & 0,99 & & & & & \\
\hline 268 & & & & & & & & & & & & & 319 & & 0,31 & 1,00 & & & & & & & \\
\hline 269 & & & 0,17 & 0,60 & 0,31 & 0,84 & 0,22 & 0,98 & & & 0,13 & 0,96 & 320 & & 0,32 & 1,00 & & & & & & & \\
\hline 270 & & & 0,07 & 1,00 & 0,21 & 0,91 & 0,08 & 1,00 & & & 0,24 & 0,97 & 321 & & 0,22 & 1,00 & & & & & & & \\
\hline 271 & & & 0,09 & 1,00 & 0,21 & 0,91 & 0,09 & 1,00 & & & 0,24 & 0,92 & 322 & & 0,15 & 1,00 & & & & & & & \\
\hline 272 & & & 0,13 & 0,70 & 0,26 & 0,79 & 0,11 & 0,81 & & & 0,27 & 0,82 & 323 & & 0,31 & 1,00 & & & & & & & \\
\hline 273 & & & 0,14 & 0,82 & 0,27 & 1,00 & 0,07 & 0,90 & & & 0,28 & 0,98 & 324 & & 0,3 & 0,92 & & & & & & & \\
\hline 274 & & & 0,07 & 1,00 & 0,16 & 0,80 & 0,48 & 1,00 & & & 0,08 & 1,00 & 325 & & 0,19 & 0,99 & & & & & & & \\
\hline 275 & & & 0,11 & 1,00 & 0,25 & 1,00 & 0,34 & 1,00 & & & 0,22 & 1,00 & 326 & & 0,15 & 1,00 & & & & & & & \\
\hline 276 & & & 0,12 & 1,00 & 0,27 & 1,00 & 0,08 & 1,00 & & & 0,21 & 1,00 & 327 & & 0,2 & 0,97 & & & & & & & \\
\hline 277 & & & 0,13 & 1,00 & 0,24 & 1,00 & 0,09 & 1,00 & & & 0,21 & 1,00 & 328 & & 0,3 & 0,92 & & & & & & & \\
\hline 278 & & & 0,17 & 1,00 & 0,3 & 0,94 & 0,07 & 1,00 & & & 0,25 & 1,00 & 329 & & 0,39 & 0,97 & & & & & & & \\
\hline 279 & & & 0,18 & 1,00 & 0,31 & 0,81 & 0,06 & 0,57 & & & 0,27 & 1,00 & 330 & & 0,18 & 1,00 & & & & & & & \\
\hline
\end{tabular}


Anexo 8 - Variação do diâmetro máximo (DMax) e transpiração relativa da planta (TRR) no pomar jovem.

\begin{tabular}{|c|c|c|c|c|c|c|c|c|c|c|c|c|c|c|c|c|c|c|c|c|c|c|}
\hline Dia Juliano & $\begin{array}{l}\text { Plan } \\
\text { DMax }\end{array}$ & $\begin{array}{l}\operatorname{ta} 1 \\
\operatorname{TRR}\end{array}$ & $\begin{array}{c}\text { Plan } \\
\text { DMax }\end{array}$ & $\begin{array}{l}\operatorname{ta} 2 \\
\text { TRR } \\
\end{array}$ & $\begin{array}{l}\text { Plan } \\
\text { DMax }\end{array}$ & $\begin{array}{l}\text { ta } 3 \\
\text { TRR } \\
\end{array}$ & $\begin{array}{l}\text { Plant } \\
\text { DMax }\end{array}$ & $\begin{array}{l}\text { ta } 4 \\
\text { TRR } \\
\end{array}$ & $\begin{array}{l}\text { Plan } \\
\text { DMax }\end{array}$ & $\begin{array}{l}\text { ta } 5 \\
\text { TRR }\end{array}$ & $\begin{array}{l}\text { Plan } \\
\text { DMax }\end{array}$ & $\begin{array}{l}\operatorname{ta} 6 \\
\text { TRR } \\
\end{array}$ & $\begin{array}{r}\text { Planta } 1 \\
\text { pia Juliano DMax TRR } \\
\end{array}$ & $\begin{array}{c}\text { Plan } \\
\text { DMax }\end{array}$ & $\begin{array}{l}\operatorname{ta2} 2 \\
\operatorname{TRR}\end{array}$ & $\begin{array}{l}\text { Plan } \\
\text { DMax }\end{array}$ & $\begin{array}{l}\operatorname{ta3} 3 \\
\text { TRR }\end{array}$ & $\begin{array}{l}\text { Plan } \\
\text { DMax }\end{array}$ & $\begin{array}{l}\text { ta } 4 \\
\text { TRR }\end{array}$ & $\begin{array}{c}\text { Planta } 5 \\
\text { DMax TRR } \\
\end{array}$ & $\begin{array}{l}P \operatorname{Plant} \\
D \max \end{array}$ & $\begin{array}{l}\operatorname{ta} 6 \\
\operatorname{TRR}\end{array}$ \\
\hline 229 & $-0,11$ & 0,79 & 0,05 & 1,00 & & & 0,05 & 1,00 & 0,08 & 0,78 & 0,09 & 0,93 & 280 & 0,05 & 1,00 & 0,08 & 0,54 & 0,06 & 1,00 & & 0,1 & 0,80 \\
\hline 230 & 0,08 & 0,86 & 0,05 & 1,00 & & & 0,03 & 0,95 & 0,07 & 0,72 & 0,02 & 0,59 & 281 & 0,04 & 1,00 & 0,07 & 0,82 & 0 & 1,00 & & 0,15 & 1,00 \\
\hline 231 & 0,04 & 0,77 & 0,08 & 1,00 & & & 0,09 & 1,00 & 0,08 & 0,98 & 0,12 & 0,83 & 282 & 0,04 & 0,87 & 0,09 & 0,84 & 0,02 & 1,00 & & 0,02 & 1,00 \\
\hline 232 & 0,03 & 0,68 & 0,06 & 1,00 & & & 0,12 & 0,93 & 0,07 & 1,00 & 0,14 & 1,00 & 283 & 0,01 & 0,93 & 0,06 & 1,00 & 0,06 & 1,00 & & 0,05 & 1,00 \\
\hline 233 & 0,03 & 0,64 & 0,05 & 1,00 & & & 0,05 & 0,97 & 0,08 & 1,00 & 0,12 & 1,00 & 284 & 0,03 & 0,84 & 0,04 & 1,00 & 0,02 & 1,00 & & 0,02 & 1,00 \\
\hline 234 & 0,08 & 0,67 & 0,07 & 1,00 & & & 0,09 & 1,00 & 0,09 & 1,00 & 0,16 & 1,00 & 285 & 0,02 & 0,85 & 0,01 & 1,00 & 0,02 & 1,00 & & $-0,04$ & 1,00 \\
\hline 235 & 0,03 & 0,60 & 0,07 & 1,00 & & & 0,15 & 0,91 & 0,1 & 0,88 & 0,17 & 1,00 & 286 & $-0,01$ & 0,89 & 0 & 0,94 & $-0,01$ & 1,00 & & $-0,18$ & 1,00 \\
\hline 236 & 0,03 & 0,77 & 0,05 & & & & 0,07 & 0,60 & 0,07 & 0,81 & 0,16 & 1,00 & 287 & 0,01 & 0,84 & 0,07 & 0,90 & 0,08 & 1,00 & & 0 & 1,00 \\
\hline $\begin{array}{l}237 \\
238\end{array}$ & $\begin{array}{r}0,02 \\
-0,17\end{array}$ & $\begin{array}{l}0,70 \\
0,59\end{array}$ & $\begin{array}{l}0,04 \\
0,07\end{array}$ & $\begin{array}{l}1,00 \\
1,00\end{array}$ & & & $\begin{array}{l}0,08 \\
0,18\end{array}$ & $\begin{array}{l}0,90 \\
0,54\end{array}$ & $\begin{array}{l}0,07 \\
0,09\end{array}$ & $\begin{array}{l}0,88 \\
0,92\end{array}$ & $\begin{array}{l}0,12 \\
0,14\end{array}$ & 1,00 & $\begin{array}{l}288 \\
289\end{array}$ & $\begin{array}{r}0 \\
-0,01\end{array}$ & $\begin{array}{l}0,79 \\
0,78\end{array}$ & $\begin{array}{l}0,01 \\
0,04\end{array}$ & $\begin{array}{l}0,85 \\
0,82\end{array}$ & $\begin{array}{r}-0,03 \\
0,02\end{array}$ & 1,00 & & $\begin{array}{l}-0,01 \\
-0,01\end{array}$ & 1,00 \\
\hline 238 & & & & & & & & & & & & & 289 & & & & 0,82 & 0,02 & 1,00 & & $-0,01$ & 0,98 \\
\hline 239 & $-0,15$ & 0,67 & 0,02 & 1,00 & 0,03 & 0,69 & $-0,01$ & 1,00 & 0,07 & 1,00 & 0,3 & 1,00 & 290 & 0,02 & 0,75 & 0,06 & 0,95 & $-0,02$ & 1,00 & & $-0,03$ & 0,75 \\
\hline 240 & $-0,01$ & 0,74 & 0,07 & 1,00 & 0,06 & 0,48 & 0,06 & 1,00 & 0,1 & 1,00 & 0,15 & 1,00 & 291 & 0,01 & 0,62 & 0,05 & 0,70 & $-0,11$ & 1,00 & & $-0,06$ & 0,65 \\
\hline 241 & $-0,05$ & 0,63 & 0,01 & 1,00 & 0,04 & 1,00 & 0,04 & 1,00 & 0,07 & 0,85 & 0,06 & 1,00 & 292 & 0,03 & 0,73 & 0,04 & 0,61 & 0,03 & 1,00 & & $-0,01$ & 0,84 \\
\hline 242 & 0,19 & 0,85 & 0,16 & 1,00 & 0,05 & 0,90 & 0,1 & 1,00 & 0,12 & 0,91 & 0,13 & 1,00 & 293 & 0,06 & 0,77 & 0,04 & 0,67 & 0,01 & 1,00 & & 0,14 & 0,89 \\
\hline 243 & 0,06 & 0,66 & 0,1 & 1,00 & 0,15 & 1,00 & 0,16 & 0,76 & 0,1 & 0,63 & 0,18 & 1,00 & 294 & 0,02 & 0,77 & 0,03 & 0,62 & 0,04 & 0,65 & & 0,05 & 0,89 \\
\hline 244 & $-0,01$ & 1,00 & 0,05 & 0,98 & 0,02 & 0,77 & 0 & 0,25 & 0,05 & 0,98 & 0,08 & 1,00 & 295 & 0,05 & 0,75 & 0,07 & 0,57 & 0,12 & 1,00 & & 0,02 & 0,80 \\
\hline 245 & $-0,07$ & 0,79 & $-0,07$ & 1,00 & $-0,03$ & 0,93 & 0,09 & 0,47 & 0 & 1,00 & 0,03 & 1,00 & 296 & 0,03 & 0,57 & 0,03 & 0,93 & $-0,06$ & 1,00 & & 0,03 & 1,00 \\
\hline 246 & 0 & 0,61 & 0,04 & 1,00 & 0,07 & 0,92 & 0,04 & 0,94 & 0,06 & 1,00 & 0,12 & 1,00 & 297 & 0 & 0,95 & 0,02 & 0,87 & & & & 0,07 & 0,43 \\
\hline 247 & 0,03 & 0,94 & 0,06 & 1,00 & 0,05 & 0,62 & 0,02 & 0,61 & 0,06 & 0,86 & 0,07 & 0,94 & 298 & 0,07 & 0,95 & 0,09 & 0,77 & & & & 0,12 & 1,00 \\
\hline 248 & 0,03 & 0,79 & 0,05 & 1,00 & 0,05 & 0,54 & 0,01 & 0,53 & 0,07 & 0,66 & 0,08 & 0,92 & 299 & 0,07 & 0,94 & 0,12 & 0,69 & & & & 0,12 & 1,00 \\
\hline 249 & 0,09 & 0,89 & 0,08 & 1,00 & 0,07 & 0,54 & 0,08 & 0,32 & 0,1 & 1,00 & 0,15 & 0,86 & 300 & 0,06 & 0,96 & 0 & 1,00 & & & & 0,08 & 1,00 \\
\hline 250 & 0 & 1,00 & 0,1 & 0,79 & 0,03 & 0,97 & 0,03 & 0,83 & 0,12 & 0,43 & 0,36 & 0,47 & 301 & 0,03 & 0,94 & 0,01 & 0,84 & & & & 0,04 & 1,00 \\
\hline 251 & 0 & 0,88 & $-0,15$ & 1,00 & 0 & 0,83 & 0,04 & 1,00 & 0,04 & 1,00 & 0,04 & 1,00 & 302 & 0,17 & 0,94 & 0,06 & 0,77 & & & & 0,06 & 0,98 \\
\hline 252 & 0,07 & 0,83 & 0,04 & 1,00 & 0,08 & 0,71 & 0,14 & 0,55 & 0,05 & 0,94 & 0,11 & 1,00 & 303 & 0,15 & 1,00 & 0,17 & 0,93 & & & & 0,23 & 0,84 \\
\hline 253 & 0,11 & 1,00 & 0,04 & 0,93 & 0,08 & 0,62 & $-0,05$ & 0,19 & 0,09 & 0,55 & 0,03 & 0,93 & 304 & 0,18 & 1,00 & 0,17 & 1,00 & & & & & \\
\hline 254 & 0,16 & 1,00 & 0,02 & 0,75 & 0,08 & 0,57 & 0,08 & 0,39 & 0,1 & 0,56 & 0,05 & 0,82 & 305 & 0,14 & 0,95 & 0,11 & 0,98 & & & & & \\
\hline 255 & 0,11 & 1,00 & 0,02 & 0,64 & 0,03 & 0,38 & 0,07 & 0,21 & 0,07 & 0,83 & 0,01 & 0,84 & 306 & 0,11 & 0,88 & 0,08 & 0,90 & & & & & \\
\hline 256 & 0,13 & 1,00 & 0,07 & 0,82 & 0,08 & 0,72 & 0,11 & 0,73 & 0,11 & 0,65 & 0,06 & 0,87 & 307 & 0,07 & 0,97 & 0,08 & 0,98 & & & & & \\
\hline 257 & 0,19 & 0,81 & 0,13 & 1,00 & 0,16 & 0,93 & 0,45 & 1,00 & 0,15 & 1,00 & 0,09 & 0,92 & 308 & 0 & 0,94 & 0,04 & 0,98 & & & & & \\
\hline 258 & 0,1 & 1,00 & 0,03 & 0,60 & 0,04 & 0,50 & $-0,22$ & 0,42 & 0,11 & 0,92 & 0,05 & 0,52 & 309 & 0,06 & 1,00 & 0,13 & 1,00 & & & & & \\
\hline 259 & 0,11 & 0,83 & 0,06 & 1,00 & 0,06 & 0,90 & 0,35 & 1,00 & 0,1 & 1,00 & $-0,01$ & 1,00 & 310 & $-0,01$ & 1,00 & 0,05 & 0,96 & & & & & \\
\hline 260 & 0,08 & 1,00 & 0,05 & 0,76 & 0,08 & 0,30 & $-0,14$ & 0,48 & 0,1 & 0,99 & 0,09 & 0,83 & 311 & 0,02 & 0,94 & 0,02 & 0,69 & & & & & \\
\hline 261 & & & & & & & & & & & & & 312 & 0,12 & 0,93 & 0,015 & 0,60 & & & & & \\
\hline 262 & & & & & & & & & & & & & 313 & 0,06 & 0,82 & 0,102 & 0,40 & & & & & \\
\hline 263 & & & 0,08 & 0,92 & 0,32 & 1,00 & 0 & 1,00 & & & 0,196 & 1,00 & 314 & 0,02 & 1,00 & 0,024 & 0,72 & & & & & \\
\hline 264 & & & 0,13 & 1,00 & 0,16 & 0,76 & 0 & 1,00 & & & 0,14 & 1,00 & 315 & & & & & & & & & \\
\hline 265 & & & $-0,08$ & 1,00 & $-0,09$ & 0,68 & 0 & 1,00 & & & $-0,08$ & 1,00 & 316 & 0,09 & 0,98 & 0,131 & 1,00 & & & & & \\
\hline 266 & & & & & & & & & & & & & 317 & $-0,02$ & 1,00 & $-0,03$ & 1,00 & & & & & \\
\hline 267 & & & & & & & & & & & & & 318 & 0,08 & 0,91 & $-0,06$ & 0,99 & & & & & \\
\hline 268 & & & & & & & & & & & & & 319 & 0,17 & 1,00 & & & & & & & \\
\hline 269 & & & 0,2 & 0,60 & 0,31 & 0,84 & 3,05 & 0,98 & & & 0,17 & 0,96 & 320 & 0,4 & 1,00 & & & & & & & \\
\hline 270 & & & 0,07 & 1,00 & 0,22 & 0,91 & $-0,1$ & 1,00 & & & 0,19 & 0,97 & 321 & 0 & 1,00 & & & & & & & \\
\hline 271 & & & 0,06 & 1,00 & 0,11 & 0,91 & 0,05 & 1,00 & & & 0,06 & 0,92 & 322 & 0,02 & 1,00 & & & & & & & \\
\hline 272 & & & 0,08 & 0,70 & 0,14 & 0,79 & 0,09 & 0,81 & & & 0,1 & 0,82 & 323 & 0,35 & 1,00 & & & & & & & \\
\hline 273 & & & 0,05 & 0,82 & 0,09 & 1,00 & 0,01 & 0,90 & & & 0,06 & 0,98 & 324 & 0,09 & 0,92 & & & & & & & \\
\hline 274 & & & 0,08 & 1,00 & 0,18 & 0,80 & 0,35 & 1,00 & & & 0,06 & 1,00 & 325 & 0,04 & 0,99 & & & & & & & \\
\hline 275 & & & 0,02 & 1,00 & 0,05 & 1,00 & 0,06 & 1,00 & & & 0,06 & 1,00 & 326 & 0,04 & 1,00 & & & & & & & \\
\hline 276 & & & 0,07 & 1,00 & 0,11 & 1,00 & $-0,18$ & 1,00 & & & 0,09 & 1,00 & 327 & 0,08 & 0,97 & & & & & & & \\
\hline 277 & & & 0,06 & 1,00 & 0,07 & 1,00 & 0,06 & 1,00 & & & 0,08 & 1,00 & 328 & 0,09 & 0,92 & & & & & & & \\
\hline 278 & & & 0,06 & 1,00 & 0,12 & 0,94 & 0,06 & 1,00 & & & 0,12 & 1,00 & 329 & 0,01 & 0,97 & & & & & & & \\
\hline 279 & & & 0,04 & 1,00 & 0,09 & 0,81 & 0,07 & 0,57 & & & 0,08 & 1,00 & 330 & 0,07 & 1,00 & & & & & & & \\
\hline
\end{tabular}


Anexo 9 - Valores da evolução do diâmetro mínimo (DMin) e da transpiração relativa da planta (TRR) no pomar jovem.

\begin{tabular}{|c|c|c|c|c|c|c|c|c|c|c|c|c|c|c|c|c|c|c|c|c|c|c|}
\hline Jia Juliano & $\begin{array}{r}\text { Plan } \\
\text { DMin } \\
\end{array}$ & $\begin{array}{r}\text { ta } 1 \\
\text { TRR } \\
\end{array}$ & $\begin{array}{c}\text { Plan } \\
\text { DMin }\end{array}$ & $\begin{array}{l}\text { ta } 2 \\
\text { TRR }\end{array}$ & $\begin{array}{r}\text { Plan } \\
\text { DMin }\end{array}$ & $\begin{array}{l}\text { ta } 3 \\
\text { TRR } \\
\end{array}$ & $\begin{array}{r}\text { Plan } \\
\text { DMin }\end{array}$ & $\begin{array}{l}\text { ta } 4 \\
\text { TRR }\end{array}$ & $\begin{array}{c}\text { Plan } \\
\text { DMin }\end{array}$ & $\begin{array}{l}\text { ta } 5 \\
\text { TRR }\end{array}$ & $\begin{array}{c}\text { Plan } \\
\text { DMin }\end{array}$ & $\begin{array}{l}\text { ta } 6 \\
\text { TRR } \\
\end{array}$ & \begin{tabular}{|cc}
\multicolumn{3}{c}{ Planta 1} \\
Ba Juliano DMin & TRR \\
\end{tabular} & $\begin{array}{l}\text { Plant } \\
\text { DMin }\end{array}$ & $\begin{array}{l}\text { ta } 2 \\
\text { TRR } \\
\end{array}$ & $\begin{array}{c}\text { Plan } \\
\text { DMin }\end{array}$ & $\begin{array}{l}\text { ta } 3 \\
\text { TRR } \\
\end{array}$ & $\begin{array}{c}\text { Plan } \\
\text { DMin }\end{array}$ & $\begin{array}{r}\text { ta } 4 \\
\text { TRR } \\
\end{array}$ & $\begin{array}{r}\text { Planta } 5 \\
\text { DMin TRR } \\
\end{array}$ & $\begin{array}{l}\text { Plant } \\
\text { DMin }\end{array}$ & $\begin{array}{r}\text { ta } 6 \\
\text { TRR } \\
\end{array}$ \\
\hline 229 & $-0,15$ & 0,79 & 0,06 & 1,00 & & & 0,06 & 1,00 & 0,07 & 0,78 & 0,07 & 0,93 & 280 & 0,01 & 1,00 & 0,03 & 0,54 & 0,02 & 1,00 & & 0,07 & 0,80 \\
\hline 230 & $-0,01$ & 0,86 & 0,066 & 1,00 & & & 0,07 & 0,95 & 0,09 & 0,72 & 0,1 & 0,59 & 281 & 0,07 & 1,00 & 0,09 & 0,82 & 0,03 & 1,00 & & 0,17 & 1,00 \\
\hline 231 & 0,02 & 0,77 & 0,063 & 1,00 & & & 0,1 & 1,00 & 0,08 & 0,98 & 0,1 & 0,83 & 282 & 0,01 & 0,87 & 0,1 & 0,84 & 0,04 & 1,00 & & $-0,06$ & 1,00 \\
\hline 232 & 0,02 & 0,68 & 0,053 & 1,00 & & & 0,08 & 0,93 & 0,07 & 1,00 & 0,12 & 1,00 & 283 & 0,04 & 0,93 & 0,02 & 1,00 & 0,03 & 1,00 & & 0,01 & 1,00 \\
\hline 233 & 0,04 & 0,64 & 0,05 & 1,00 & & & 0,08 & 0,97 & 0,07 & 1,00 & 0,13 & 1,00 & 284 & 0,02 & 0,84 & 0,01 & 1,00 & 0,03 & 1,00 & & $-0,03$ & 1,00 \\
\hline 234 & 0,05 & 0,67 & 0,07 & 1,00 & & & 0,09 & 1,00 & 0,09 & 1,00 & 0,11 & 1,00 & 285 & 0,01 & 0,85 & 0,05 & 1,00 & 0,03 & 1,00 & & $-0,03$ & 1,00 \\
\hline 235 & 0,03 & 0,60 & 0,04 & 1,00 & & & 0,11 & 0,91 & 0,1 & 0,88 & 0,14 & 1,00 & 286 & $-0,01$ & 0,89 & $-0,02$ & 0,94 & $-0,03$ & 1,00 & & $-0,19$ & 1,00 \\
\hline $\begin{array}{l}236 \\
237\end{array}$ & $\begin{array}{r}0,03 \\
-0,13\end{array}$ & $\begin{array}{l}0,77 \\
0,70\end{array}$ & $\begin{array}{l}0,04 \\
0,03\end{array}$ & $\begin{array}{l}1,00 \\
1,00\end{array}$ & & & $\begin{array}{l}0,09 \\
0,07\end{array}$ & $\begin{array}{l}0,60 \\
0,90\end{array}$ & $\begin{array}{l}0,08 \\
0,06\end{array}$ & $\begin{array}{l}0,81 \\
0,88\end{array}$ & $\begin{array}{l}0,16 \\
0,13\end{array}$ & $\begin{array}{l}1,00 \\
1,00\end{array}$ & $\begin{array}{l}287 \\
288\end{array}$ & $\begin{array}{r}0 \\
0,02\end{array}$ & $\begin{array}{l}0,84 \\
0,79\end{array}$ & $\begin{array}{l}0,04 \\
0,08\end{array}$ & $\begin{array}{l}0,90 \\
0,85\end{array}$ & $\begin{array}{l}0,01 \\
0,08\end{array}$ & $\begin{array}{l}1,00 \\
1,00\end{array}$ & & $\begin{array}{r}-0,05 \\
0,09\end{array}$ & $\begin{array}{l}1,00 \\
1,00\end{array}$ \\
\hline 238 & $-0,07$ & 0,59 & 0,06 & 1,00 & & & 0,09 & 0,54 & 0,09 & 0,92 & 0,1 & 1,00 & 289 & 0 & 0,78 & 0,07 & 0,82 & $-0,07$ & 1,00 & & $-0,05$ & 0,98 \\
\hline 239 & $-0,11$ & 0,67 & 0,02 & 1,00 & 0,02 & 0,69 & 0,06 & 1,00 & 0,07 & 1,00 & 0,3 & 1,00 & 290 & $-0,01$ & 0,75 & 0,05 & 0,95 & $-0,07$ & 1,00 & & $-0,04$ & 0,75 \\
\hline 240 & $-0,01$ & 0,74 & 0,04 & 1,00 & 0,04 & 0,48 & 0,07 & 1,00 & 0,06 & 1,00 & 0,12 & 1,00 & 291 & 0 & 0,62 & $-0,03$ & 0,70 & $-0,04$ & 1,00 & & $-0,08$ & 0,65 \\
\hline 241 & 0,06 & 0,63 & 0,11 & 1,00 & 0,11 & 1,00 & 0,1 & 1,00 & 0,1 & 0,85 & 0,1 & 1,00 & 292 & 0,06 & 0,73 & 0,07 & 0,61 & $-0,04$ & 1,00 & & 0,08 & 0,84 \\
\hline 242 & 0,19 & 0,85 & 0,14 & 1,00 & 0,16 & 0,90 & 0,09 & 1,00 & 0,09 & 0,91 & 0,19 & 1,00 & 293 & 0,04 & 0,77 & 0,04 & 0,67 & 0,06 & 1,00 & & 0,12 & 0,89 \\
\hline 243 & 0,22 & 0,66 & 0,21 & 1,00 & 0,1 & 1,00 & 0,16 & 0,76 & 0,13 & 0,63 & 0,2 & 1,00 & 294 & 0,04 & 0,77 & 0,06 & 0,62 & 0,06 & 0,65 & & 0,04 & 0,89 \\
\hline 244 & $-0,11$ & 1,00 & $-0,05$ & 0,98 & $-0,03$ & 0,77 & $-0,04$ & 0,25 & 0,01 & 0,98 & 0,07 & 1,00 & 295 & 0,05 & 0,75 & 0,08 & 0,57 & 0,04 & 1,00 & & 0,03 & 0,80 \\
\hline 245 & 0,02 & 0,79 & 0,05 & 1,00 & 0,05 & 0,93 & 0,02 & 0,47 & 0,08 & 1,00 & 0,07 & 1,00 & 296 & 0,02 & 0,57 & 0,06 & 0,93 & 0,01 & 1,00 & & 0,05 & 1,00 \\
\hline 246 & 0 & 0,61 & 0,02 & 1,00 & 0,03 & 0,92 & 0,06 & 0,94 & 0,03 & 1,00 & 0,05 & 1,00 & 297 & $-0,06$ & 0,95 & 0,01 & 0,87 & & & & 0,06 & 0,43 \\
\hline 247 & $-0,05$ & 0,94 & $-0,01$ & 1,00 & 0,02 & 0,62 & 0,02 & 0,61 & 0,06 & 0,86 & 0,09 & 0,94 & 298 & 0,06 & 0,95 & 0,06 & 0,77 & & & & 0,08 & 1,00 \\
\hline 248 & 0,11 & 0,79 & 0,1 & 1,00 & 0,09 & 0,54 & 0,07 & 0,53 & 0,07 & 0,66 & 0,11 & 0,92 & 299 & 0,09 & 0,94 & 0,11 & 0,69 & & & & 0,1 & 1,00 \\
\hline 249 & $-0,08$ & 0,89 & $-0,05$ & 1,00 & $-0,03$ & 0,54 & 0,06 & 0,32 & 0,07 & 1,00 & 0,12 & 0,86 & 300 & 0,06 & 0,96 & 0,05 & 1,00 & & & & 0,09 & 1,00 \\
\hline 250 & 0,11 & 1,00 & 0,14 & 0,79 & 0,09 & 0,97 & 0,08 & 0,83 & 0,12 & 0,43 & 0,25 & 0,47 & 301 & $-0,03$ & 0,94 & 0,04 & 0,84 & & & & 0,03 & 1,00 \\
\hline 251 & 0,07 & 0,88 & $-0,03$ & 1,00 & 0,05 & 0,83 & 0,02 & 1,00 & 0,05 & 1,00 & 0,17 & 1,00 & 302 & 0,22 & 0,94 & 0,07 & 0,77 & & & & 0,1 & 0,98 \\
\hline 252 & 0,05 & 0,83 & 0,03 & 1,00 & 0,06 & 0,71 & 0,05 & 0,55 & 0,07 & 0,94 & 0,01 & 1,00 & 303 & 0,29 & 1,00 & 0,32 & 0,93 & & & & 0,38 & 0,84 \\
\hline 253 & 0,13 & 1,00 & 0,02 & 0,93 & 0,04 & 0,62 & 0,07 & 0,19 & 0,08 & 0,55 & $-0,01$ & 0,93 & 304 & 0,21 & 1,00 & 0,17 & 1,00 & & & & & \\
\hline 254 & 0,08 & 1,00 & $-0,01$ & 0,75 & 0,03 & 0,57 & 0,07 & 0,39 & 0,08 & 0,56 & $-0,01$ & 0,82 & 305 & 0,12 & 0,95 & 0,11 & 0,98 & & & & & \\
\hline 255 & 0,01 & 1,00 & $-0,01$ & 0,64 & 0 & 0,38 & 0,07 & 0,21 & 0,07 & 0,83 & $-0,02$ & 0,84 & 306 & 0,05 & 0,88 & 0,04 & 0,90 & & & & & \\
\hline 256 & 0,27 & 1,00 & 0,14 & 0,82 & 0,18 & 0,72 & 0,13 & 0,73 & 0,13 & 0,65 & 0,12 & 0,87 & 307 & 0,02 & 0,97 & 0,03 & 0,98 & & & & & \\
\hline 257 & 0,18 & 0,81 & 0,1 & 1,00 & 0,11 & 0,93 & 0,15 & 1,00 & 0,12 & 1,00 & 0 & 0,92 & 308 & 0,02 & 0,94 & 0,03 & 0,98 & & & & & \\
\hline 258 & 0,06 & 1,00 & 0,03 & 0,60 & 0,04 & 0,50 & 0,07 & 0,42 & 0,14 & 0,92 & 0,06 & 0,52 & 309 & 0 & 1,00 & 0,04 & 1,00 & & & & & \\
\hline 259 & 0,2 & 0,83 & 0,11 & 1,00 & 0,12 & 0,90 & 0,1 & 1,00 & 0,1 & 1,00 & 0,09 & 1,00 & 310 & $-0,08$ & 1,00 & $-0,09$ & 0,96 & & & & & \\
\hline 260 & 0 & 1,00 & 0,01 & 0,76 & $-0,01$ & 0,30 & 0,06 & 0,48 & 0,08 & 0,99 & 0,06 & 0,83 & 311 & 0,14 & 0,94 & 0,164 & 0,69 & & & & & \\
\hline 261 & & & & & & & & & & & & & 312 & 0,14 & 0,93 & 0,107 & 0,60 & & & & & \\
\hline 262 & & & & & & & & & & & & & 313 & 0,09 & 0,82 & 0,035 & 0,40 & & & & & \\
\hline 263 & & & 0,17 & 0,92 & 0,36 & 1,00 & 0 & 1,00 & & & 0,28 & 1,00 & 314 & 0 & 1,00 & 0,077 & 0,72 & & & & & \\
\hline 264 & & & 0,1 & 1,00 & 0,14 & 0,76 & 0 & 1,00 & & & 0,05 & 1,00 & 315 & & & & & & & & & \\
\hline 265 & & & $-0,02$ & 1,00 & $-0,07$ & 0,68 & 0,01 & 1,00 & & & 0,03 & 1,00 & 316 & $-0,01$ & 0,98 & 0,038 & 1,00 & & & & & \\
\hline 266 & & & & & & & & & & & & & 317 & 0,02 & 1,00 & $-0,12$ & 1,00 & & & & & \\
\hline 267 & & & & & & & & & & & & & 318 & 0,1 & 0,91 & $-0,08$ & 0,99 & & & & & \\
\hline 268 & & & & & & & & & & & & & 319 & 0,28 & 1,00 & & & & & & & \\
\hline 269 & & & 0,08 & 0,60 & 0,13 & 0,84 & $-0,08$ & 0,98 & & & 0,14 & 0,96 & 320 & 0,17 & 1,00 & & & & & & & \\
\hline 270 & & & 0,17 & 1,00 & 0,32 & 0,91 & 0,04 & 1,00 & & & 0,08 & 0,97 & 321 & 0,1 & 1,00 & & & & & & & \\
\hline 271 & & & 0,04 & 1,00 & 0,11 & 0,91 & 0,04 & 1,00 & & & 0,06 & 0,92 & 322 & 0,09 & 1,00 & & & & & & & \\
\hline 272 & & & 0,04 & 0,70 & 0,09 & 0,79 & 0,07 & 0,81 & & & 0,07 & 0,82 & 323 & 0,19 & 1,00 & & & & & & & \\
\hline 273 & & & 0,04 & 0,82 & 0,08 & 1,00 & 0,08 & 0,90 & & & 0,05 & 0,98 & 324 & 0,1 & 0,92 & & & & & & & \\
\hline 274 & & & 0,15 & 1,00 & 0,29 & 0,80 & 0,06 & 1,00 & & & 0,26 & 1,00 & 325 & 0,15 & 0,99 & & & & & & & \\
\hline 275 & & & $-0,02$ & 1,00 & $-0,04$ & 1,00 & 0,05 & 1,00 & & & $-0,08$ & 1,00 & 326 & 0,08 & 1,00 & & & & & & & \\
\hline 276 & & & 0,06 & 1,00 & 0,09 & 1,00 & 0,08 & 1,00 & & & 0,1 & 1,00 & 327 & 0,03 & 0,97 & & & & & & & \\
\hline 277 & & & 0,05 & 1,00 & 0,1 & 1,00 & 0,06 & 1,00 & & & 0,08 & 1,00 & 328 & $-0,01$ & 0,92 & & & & & & & \\
\hline 278 & & & 0,02 & 1,00 & 0,06 & 0,94 & 0,07 & 1,00 & & & 0,08 & 1,00 & 329 & $-0,08$ & 0,97 & & & & & & & \\
\hline 279 & & & 0,03 & 1,00 & 0,08 & 0,81 & 0,08 & 0,57 & & & 0,06 & 1,00 & 330 & 0,33 & 1,00 & & & & & & & \\
\hline
\end{tabular}


Anexo 10 - Calendário de irrigação (L/planta) e ocorrência de chuva (mm) das plantas jovens durante o trabalho experimental desenvolvido em 2002.

\begin{tabular}{|c|c|c|c|c|c|c|c|c|}
\hline Data & Dia Juliano & Planta 1 & Planta 2 & Planta 3 & Planta 4 & Planta 5 & Planta 6 & Chuva \\
\hline 01/Ago & 213 & & & & & & & 39,4 \\
\hline 02/Ago & 214 & & & & & & & 22,4 \\
\hline 03/Ago & 215 & & & & & & & 3,5 \\
\hline 04/Ago & 216 & & & & & & & 0,1 \\
\hline 05/Ago & 217 & & & & & & & 0 \\
\hline 06/Ago & 218 & & & & & & & 3,8 \\
\hline 07/Ago & 219 & & & & & & & 0 \\
\hline 08/Ago & 220 & & & & & & & 0 \\
\hline 09/Ago & 221 & & & & & & & 0 \\
\hline 10/Ago & 222 & & & & & & & 0 \\
\hline 11/Ago & 223 & & & & & & & 0 \\
\hline 12/Ago & 224 & & & & & & & 0 \\
\hline 13/Ago & 225 & & & & & & & 0 \\
\hline 14/Ago & 226 & & & & & & & 0 \\
\hline 15/Ago & 227 & & & & & & & 0 \\
\hline 16/Ago & 228 & & & & & & & 0 \\
\hline 17/Ago & 229 & & & & & & & 0 \\
\hline 18/Ago & 230 & & & & & & & 0 \\
\hline 19/Ago & 231 & & & & & & & 0 \\
\hline 20/Ago & 232 & & & & & & & 0 \\
\hline 21/Ago & 233 & & & & & & & 0 \\
\hline 22/Ago & 234 & & & & & & & 0 \\
\hline 23/Ago & 235 & & & & & & & 0 \\
\hline 24/Ago & 236 & & & & & & & 0 \\
\hline 25/Ago & 237 & & & & & & & 0 \\
\hline 26/Ago & 238 & & & & & & & 0 \\
\hline 27/Ago & 239 & & & & & & & 0 \\
\hline 28/Ago & 240 & & & & & & & 0 \\
\hline 29/Ago & 241 & & & & & & & 12,6 \\
\hline 30/Ago & 242 & & & & & & & 1,3 \\
\hline 31/Ago & 243 & & & & & & & 4,8 \\
\hline $01 /$ Set & 244 & & & & & & & 0,1 \\
\hline $02 /$ Set & 245 & & & & & & & 0 \\
\hline $03 /$ Set & 246 & & & & & & & 0 \\
\hline $04 /$ Set & 247 & 20 & & & & & & 0 \\
\hline $05 /$ Set & 248 & & & & & & & 0 \\
\hline $06 /$ Set & 249 & & & & & & & 0 \\
\hline $07 /$ Set & 250 & & & & & & & 11,1 \\
\hline $08 /$ Set & 251 & & & & & & & 0 \\
\hline $09 /$ Set & 252 & & & & & & & 0 \\
\hline $10 /$ Set & 253 & & & & & & & 0 \\
\hline $11 /$ Set & 254 & & & & & & & 0 \\
\hline $12 /$ Set & 255 & & 10 & 10 & 10 & & & 0 \\
\hline $13 /$ Set & 256 & & 40 & 40 & & 10 & & 0 \\
\hline $14 /$ Set & 257 & & & & 20 & 40 & & 1,4 \\
\hline $15 /$ Set & 258 & & & & & & & 0 \\
\hline $16 /$ Set & 259 & & & & & & & 0,8 \\
\hline $17 /$ Set & 260 & 40 & 40 & 40 & & 30 & 40 & 0,1 \\
\hline $18 /$ Set & 261 & & & & & & & 10,3 \\
\hline $19 /$ Set & 262 & & & & & & & 0 \\
\hline $20 /$ Set & 263 & & & & & & & 23,9 \\
\hline $21 /$ Set & 264 & & & & & & & 6,2 \\
\hline $22 /$ Set & 265 & & & & & & & 0,5 \\
\hline $23 /$ Set & 266 & & & & & & & 0 \\
\hline 24 /Set & 267 & & & & & & & 0 \\
\hline
\end{tabular}


Anexo 10 - Calendário de irrigação (L/planta) e ocorrência de chuva (mm) das plantas jovens durante o trabalho experimental desenvolvido em 2002.

\begin{tabular}{|c|c|c|c|c|c|c|c|c|}
\hline Data & Dia Juliano & Planta 1 & Planta 2 & Planta 3 & Planta 4 & Planta 5 & Planta 6 & Chuva \\
\hline $25 /$ Set & 268 & & & & & & & 0 \\
\hline $26 /$ Set & 269 & & & & & & & 0 \\
\hline $27 /$ Set & 270 & 40 & & & & & & 0 \\
\hline $28 /$ Set & 271 & & & & & & & 0 \\
\hline $29 /$ Set & 272 & & & & & & & 0 \\
\hline $30 /$ Set & 273 & & & & & & & 0 \\
\hline 01/Out & 274 & & & & & & & 3,1 \\
\hline 02/Out & 275 & & & & & & & 0 \\
\hline 03/Out & 276 & & & & & & & 0 \\
\hline 04/Out & 277 & & & & & & & 0 \\
\hline 05/Out & 278 & & & & & & & 0 \\
\hline 06/Out & 279 & & & & & & & 0 \\
\hline 07/Out & 280 & 20 & 20 & & & 20 & 20 & 0 \\
\hline 08/Out & 281 & 10 & & 10 & 10 & & & \\
\hline 09/Out & 282 & 10 & & & 10 & 10 & & \\
\hline 10/Out & 283 & & 20 & & & & & 0 \\
\hline 11/Out & 284 & & & & & & & \\
\hline 12/Out & 285 & & & & & & & \\
\hline 13/Out & 286 & & & & & & & 0,8 \\
\hline 14/Out & 287 & 20 & 20 & 20 & 10 & & 20 & 0 \\
\hline 15/Out & 288 & 20 & & 20 & & & & 0 \\
\hline $16 /$ Out & 289 & 20 & & & & & & 0 \\
\hline 17/Out & 290 & & & & & & & 0 \\
\hline 18/Out & 291 & 10 & 10 & & & & & 0 \\
\hline 19/Out & 292 & 20 & 20 & & & & 20 & 0 \\
\hline 20/Out & 293 & & & & & & & 0 \\
\hline $21 /$ Out & 294 & & & & & & & 8,3 \\
\hline 22/Out & 295 & & & & & & & 1,9 \\
\hline 23 /Out & 296 & 10 & 25 & & 15 & & & 0 \\
\hline 24/Out & 297 & 20 & & & & 20 & & 0 \\
\hline 25 /Out & 298 & & & & & & & 6,6 \\
\hline $26 /$ Out & 299 & 10 & & & & & & 0,4 \\
\hline $27 /$ Out & 300 & & & & & & & 0 \\
\hline 28/Out & 301 & 20 & 20 & & & & & 0 \\
\hline 29/Out & 302 & 20 & & & & & & 21 \\
\hline 30/Out & 303 & & & & & & & 8,4 \\
\hline 31/Out & 304 & & & & & & & 0 \\
\hline $01 / \mathrm{Nov}$ & 305 & & & & & & & 0 \\
\hline $02 / \mathrm{Nov}$ & 306 & & & & & & & 0 \\
\hline $03 / \mathrm{Nov}$ & 307 & & & & & & & 0 \\
\hline $04 / \mathrm{Nov}$ & 308 & 30 & & & & & & 0,1 \\
\hline $05 / \mathrm{Nov}$ & 309 & & & & & & & 0,6 \\
\hline 06/Nov & 310 & & & & & & & 0 \\
\hline $07 / \mathrm{Nov}$ & 311 & 20 & 20 & & & & 20 & 0 \\
\hline 08/Nov & 312 & 20 & 10 & & & & & 0 \\
\hline $09 /$ Nov & 313 & 10 & & 20 & & & & 0 \\
\hline $10 /$ Nov & 314 & & & & & & & 5,5 \\
\hline $11 / \mathrm{Nov}$ & 315 & & & & & & & 2,1 \\
\hline $12 / \mathrm{Nov}$ & 316 & & & & & & & 0,4 \\
\hline $13 / \mathrm{Nov}$ & 317 & & & & & & & 6,3 \\
\hline $14 / \mathrm{Nov}$ & 318 & & & & & & & 27,9 \\
\hline $15 / \mathrm{Nov}$ & 319 & & & & & & & 10,6 \\
\hline $16 / \mathrm{Nov}$ & 320 & & & & & & & 0 \\
\hline $17 / \mathrm{Nov}$ & 321 & & & & & & & 0 \\
\hline
\end{tabular}


Anexo 10 - Calendário de irrigação (L/planta) e ocorrência de chuva (mm) das plantas jovens durante o trabalho experimental desenvolvido em 2002.

\begin{tabular}{|c|c|c|c|c|c|c|c|c|}
\hline Data & Dia Juliano & Planta 1 & Planta 2 & Planta 3 & Planta 4 & Planta 5 & Planta 6 & Chuva \\
\hline $18 /$ Nov & 322 & & & & & & & 26,7 \\
\hline $19 / \mathrm{Nov}$ & 323 & & & & & & & 0,4 \\
\hline $20 /$ Nov & 324 & & & & & & & 0 \\
\hline $21 /$ Nov & 325 & & & & & & & 0 \\
\hline $22 / \mathrm{Nov}$ & 326 & & & & & & & 0 \\
\hline $23 / \mathrm{Nov}$ & 327 & & & & & & & 0 \\
\hline $24 / \mathrm{Nov}$ & 328 & & & & & & & 0 \\
\hline $25 / \mathrm{Nov}$ & 329 & & & & & & & 0 \\
\hline $26 /$ Nov & 330 & & & & & & & 35 \\
\hline $27 /$ Nov & 331 & & & & & & & 27,3 \\
\hline $28 / \mathrm{Nov}$ & 332 & & & & & & & 45,4 \\
\hline $29 /$ Nov & 333 & & & & & & & 0 \\
\hline
\end{tabular}




\section{REFERÊNCIAS BIBLIOGRÁFICAS}

ALLEN, R.G.; JENSEN, M.E.; WRIGHT, J.L. BURMAN, R.D. Operation estimates of reference evapotranspiration. Agronomy Journal, v.81, n.4, p.650-662, 1989.

AMARO, A.A.; MAIA, M.L.; GONZALES, M.A. Efeitos econômicos decorrentes da clorose variegada dos citros. In: DONADIO, L.C. Clorose variegada dos citros. Jaboticabal: FUNEP, 1997. p.123-135.

AMEglio, T.; ARCHER, P.; CRUIZIAT, P.; DAUDET, F.A.; COHEN, M.; VALANCOGNE, C.; DAYAU, S. A limit in the use of predawn leaf water potential for tree irrigation. Acta Horticulturae, n.449, p.431-436, 1997

ANGELOCCI, L.R. Determinação de fluxo de água nas fases líquida e de vapor em plantas. Piracicaba: ESALQ, Departamento de Física e Meteorologia, 1995. 30p.

ANGELOCCI, L.R. Estimativa da transpiração máxima de macieiras (Malus spp.) em pomares pelo modelo de Pennman-Monteith. Piracicaba, 1997. 103p. Tese (LivreDocência) - Escola Superior de Agricultura "Luiz de Queiroz", Universidade de São Paulo.

ANGELOCCI, L.R. Água na planta e trocas gasosas/energéticas com a atmosfera: Introcução ao tratamento biofísico. Piracicaba: O autor, 2002. 268p.

ANGELOCCI, L.R.; VALANCOGNE, C. Leaf area and water flux in apple trees. Journal of Horticultural Science, v.68, n.2, p.299-307, 1993.

BAKER, J.M.; NIEBER, J.L. An analysis of the steady-state heat balance method for measuring sap flow in plants. Agricultural Forestry Meteorology, v.48, p.93-109, 198. 
BAKER, J.M.; VAN BAVEL, C.H.M. Measurement of mass flow of water in the stems of herbaceous plants. Plant, Cell and Environment, v.10, p.777-782, 1987.

BENYON, G.B. Nighttime water use in an irrigated Eucalyptus grandis plantation. Tree Physiology, v.19, p.853-859, 1999.

BONGANHA, C.A. Consciência "Água". Citricultura Atual, v.4, n.24, p.8-9, 2001.

BOTEON, M.; VIDAL, A.J. Citricultura paulista. Citricultura Atual, v.4, n.22, p.13, 2001.

BRAUN, P. Sap flow measurements in fruit trees - Advantages and shortfalls of currently used systems. Acta Horticulturae, n.449, p.267-272, 1997.

BRAUN, P.; SCHMID, J. Sap flow measurements in grapevines (Vitis vinifera L.). 1. Stem morphology and use of the heat balance method. Plant and Soil, v.215, p.3945, 1999.

CABIBEL, B.; DO, F. Mesures thermiques des flux de sève dans les troncs et les racines et fonctionnement hydrique des arbres: I. Analyse théorique des ereurs sur la mesure des flux et validation des mesures en présence de gradients thermiques extérieurs. Agronomie, v.11, p.669-678, 1991.

CAMPECHE, L.F.S.M. Construção, calibração e análise de funcionamento de lisémetros de pesagem para determinação da evapotranspiração da cultura da lima ácida 'Tahiti' (Citrus latifolia Tan.). Piracicaba, 2001. 67p. Tese (Doutorado) - Escola Superior de Agricultura "Luiz de Queiroz", Universidade de São Paulo.

CERMAK, J.; DEML, M.; PENKA, M. A new method of sap flow rate determination in tress. Biologia Plantarum, v.15, p.171-178, 1973.

CHRISTOFIDIS, D. Os recursos hídricos e a prática da irrigação no Brasil e no mundo. ITEM. Irrigação \& Tecnologia Moderna, n.49, p.8-13, 2001.

CLEARWATER, M.J.; MAINZER, F.C.; ANDRADE, J.L. Potential errors in measurement of no uniform sap flow using heat dissipation probes. Tree Physiology, v.19, p.681-687, 1999. 
COELHO FILHO, M.A. Determinação da transpiração máxima em um pomar jovem de lima ácida 'Tahiti' (Citrus latifolia Tan.) e sua relação com a evapotranspiração de referência. Piracicaba, 2002. 91p. Tese (Doutorado) - Escola Superior de Agricultura "Luiz de Queiroz" - Universidade de São Paulo.

COHEN, Y. Determination of orchard water requirement by a combined trunk sap flow and meteorological approach. Irrigation Science, v.12, p.93-98, 1991.

COHEN, Y.; AMELIO, T.; CRUIZIAT, P.; ARCHER, P.; VALANCOGNE, C.; DAYAU, S. Yield and physiological responses of walnut trees in semiarid conditions: application to irrigation scheduling. Acta Horticulturae, n.449, p.273$280,1997$.

COHEN, Y.; FUCHS, M. Problem in calibrating the heat pulse method for measuring sap flow in the stem of trees and herbaceous plants. Agronomie, v.9, p.321-325, 1989.

COHEN, Y.; FUCHS, M.; GREEN, G.C. Improvement of the heat pulse method for determining sap flow in trees. Pant, Cell and Environment, v.4, p.391-397, 1981.

COHEN, Y.; HUCK, M.G.; HESKETH, J.D.; FREDERICK, J.R. Sap flow in the stem of water stressed soybean and maize plants. Irrigation Science, n.11, p.45-50, 1990.

COHEN, M.; SAVÉ, R.; BIEL, C.; MARFÀ, O. Simultaneous measurements of water stress with LVDT sensors and electrotensiometers: Application in pepper plants grown in two types of perlites. Acta Horticulturae, n.421, p.193-199, 1998. /Apresentado ao 2. International Symposium on Sensors in Horticulture, Copenhagem, 1998/.

CORTE, R. Cuidados que levam ao sucesso na irrigação. Citricultura Atual, v.4, n.22, p.8-9, 2001.

COSTA, E.L.; COELHO, E.F. Irrigação de citros. Informe Agropecuário, v.22, n.209, p.54-60, 2001. 
DAVID, T.S.; FERREIRA, M.I.; DAVID, J.S.; PEREIRA, J.S. Transpiration from a mature Eucalyptus globules plantation in Portugal during a spring-summer period of progressively higher water deficit. Oecologia, v.110, p.153-159, 1997.

DAYAU, S. Realisation des capteurs pour la mesure du debit de seve dans des arbres (Methode du Bilan Chaleur). Bordeaux: INRA, s.d. 20p.

DOBBS, R.C.; SCOTT, D.R.M. Distribution of diurnal fluctuations in stem circumference of Douglas fir. Canadian Journal of Forest Research, v.1, p.80-83, 1971.

DOORENBOS J., PRUITT, W. O. Necessidades hídricas das culturas. Campina Grande: Universidade Federal da Paraíba, 1997. 204p. (FAO. Irrigação e Drenagem, 24).

DYNAMAX INC. Dynagage installation and operation manual. Houston: Texas, s.d., 80 p.

DYNAMAX INC. DEX: dendrometer installation and users guide. Houston: Dynamax, 1996. s.p

FAO PRODUCTION YEARBOOK - 2001, p.3-30, 2001.

FERREIRA, M. I.; ZITSCHER, H. Measurements performed with Granier method in short trunks near the soil. In. WORKSHOP ON MEASURING SAP FLOW IN INTACT PLANT, Barcelona,1996. Anais. 3p.

FERREIRA, M.I. Evapotranspiração e estresse hídrico em cobertos arbóreo-arbustivos numa perspectiva de gestão da água em região mediterrânica. Anais do Instituto Superior de Agonomia, v.45, p.343-385, 1996a.

FERREIRA, M.I. Evapotranspiration in several woody species of central Portugal. /Apresentado ao 14. International Congress of Biometeorology, Slovenia, 1996b/.

GARNIER, E.; BERGER, A. Effect of water stress on stem diameter changes of peach trees growing in the field. Journal of Applied Ecology, v.23, p.193-209, 1986. 
GINESTAR, C.; CASTEL, J.R. Use of stem dendrometers as indicators of water stress in drip-irrigated citrus trees. Acta Horticulturae, n.421, p.209-216, 1998. /Apresentado ao 2. International Symposium on Sensors in Horticulture, Copenhagen, $1998 /$

GOLDHAMER, D.A.; FERERES, E.; MATA, M.; GIRONA, J.; COHEN, M. Sensitivity of Continuous and discrete plant and soil water status monitoring in peach trees subjected to deficit irrigation. California. Journal of American Horticultural Science, v.124, n.4, p.437-444, 1999.

GRANIER, A. Une nouvelle méthode pour la mesure du flux de sève brute dans le tronc des arbres. Annales des Sciences Forestières, v.42, n.2, p.193-200, 1985.

GRANIER, A. Mesure du flux de sève brute dans le tronc du douglas par une nouvelle méthode thermique. Annales des Sciences Forestierès, v.44, n.1, p.1-14, 1987.

GRANIER, A.; BRÉDA, N. Modeling canopy conductance and stand transpiration of an oak forest from sap flow measurements. Annales des Sciences Forestierès, v.53, p.537-546, 1996.

GREEN, S.R. Radiation balance, transpiration and photosynthesis of an isolated tree. Agricultural and Forest Meteorology, v.64, p.201-221, 1993.

GREEN, S.R.; CLOTHIER, B.E. Water use of kiwifruit vines and apples trees by the heat-pulse technique. Journal Experimental Botany, v.39, p.115-123, 1988.

GREEN, S.R.; CLOTHIER, B.E.; Mc LEOD, D.J. The response of sap flow in apple roots to localized irrigation. Agricultural Water Management, v.33, p.63-78, 1997.

GRIME, V.L.; SINCLAIR, F.L. Sources of errors in stem heat balance sap flow measurements. Agricultural and Forest Meteorology, v.94, p.103-121, 1999.

HAM, J.M.; HEILMAN, J.L. Dynamics of a heat balance stem flow gauge during high flow. Agronomy Journal, v.82, p.147-152, 1990. 
HERZOG, K.M.; THUM, R.; SWEIFEL, R. HASLER, R. Heat balance measurements to quantify sap flow in thin stems only. Agricultural and Forest Meteorology, v.83, p.75-94, 1997.

HIGGS, K.H.; JONES, H.G. A microcomputer-based system for continuous measurement and recording fruit diameter in relation to environmental factor. Journal of Experimental Botany, v.35, n.160, p.1646-1655, 1984.

HILGEMAN, H. Trunk growth of the Valencia orange in relation to soil moisture and climate. Proceedings of the American Society for Horticultural Science, v.82, p.193-199, 1962.

HSIAO, T. Measurements of plant water status. In: STEWART, B.A.; NILSEN, D.R. (Ed.). Irrigation of agricultural crops. San Francisco: ASA, 1990. p.243-279. (Agronomy Monograph, 30).

HUGUET, J.G. Apréciation de l'état hydrique d'une plante à partir des variations micrométriques de la dimension des fruits ou des tiges au cours de la journée. Agronomie, v.5, n.8, p.733-741, 1985.

HUGUET, J.G.; ORLANDO, P. Les besoins en eau et la bioprogrammation. L'Arboriculte Fruitière, n.396, p.19-24, 1987.

HUGUET, J. G.; LI, S. H.; LORENDEAU, J. Y.; PELlOUX, G. Specific micromorphometric reactions of fruit trees to water stress and irrigation scheduling automation. Journal of Horticultural Science, v.67, n.5, p.631-640, 1992.

JACKSON, R.D. Canopy temperature and crop water stress: Water Resour. Journal of Experimental Botany, v.132, p.67-77, 1982.

KATERJI, N.; ITIER, B.; FERREIRA, I. Etude de quelques critères indicateurs de l'état hydrique d'une culture de tomate en région semi-aride. Agronomie, v.8, n.5, p.425433, 1988. 
KATERJI, N.; SCHOCH, P.G.; RINGOTO, P.; L'HOTEL, J.C. Diagnostic des périodes de contrainte hydrique chez des plantes d'aubergine cultivées en serre, au moyen des microvariations des tiges. Agronomie, n.10, p.541-549, 1990.

KATERJI, N.; TARDIEU, F.; BETHENOD, O.; QUETIN, P. Behavior of maize stem diameter during drying cycles: Comparison of two methods for detecting water stress. Crop Science, v.34, p.165-169, 1994.

KLEPPER, B.; TAYLOR, H.M.; HUCK, M.G.; FISCUS, E.L. Water relations and growth of cotton in drying soil. Agronomy Journal, p.307-310, 1973.

KRAMER, P.J.; BOYER, P.J. Water relations of plant and soils. Orlando: Academic Press, 1995. 494p.

LANDSBERG, J.J.; CUTTING, C.V. (Ed.). Environmental effects on crop physiology. New York: Academic Press, 1977. 279p.

LANDSBERG, J.J.; BEADLE, C.L.; BISCOE, P.V.; BUTLER, D.R., DAVIDSON, D.; INCOLL, L.D.; JAMES, G.B.; JARVIS, P.G.; MARTIN, P.G.; NEILSON, R.E.; POWELL, D.B.B.; SLACK, M.; THORPE, M.R.; TURNER, N.C.; WARRIT, B.; WATTS, W.R. Diurnal energy water and $\mathrm{CO}_{2}$ exchanges in apple (Malus pumila) orchard. Journal of Applied Ecology, v.12, p.659-684, 1975.

LI, S.H.; HUGUET, J.G.; SCHOCH, P.G.; BUSSI, C. Réponse de jeunes pêchers cultivés en pots à différents régimes d'alimentation hydrique. I: Conséquences sur la transpiration, la résistance stomatique, le potentiel hydrique foliaire, la photosynthèques et les variations micromorphométriques des tiges. Agronomie, n.10, p.263-272, 1990a.

LI, S.H.; HUGUET, J.G.; SCHOCH, P.G.; BUSSI, C. Réponse de jeunes pêchers cultivés en pots à différents régimes d'alimentation hydrique. II: Effets sur la croissance et le d'veloppement. Agronomie, n.10, p.353-360, $1990 \mathrm{~b}$.

LÓPEZ, J.R.; HERNÁNDEZ-ABREU, J.M.; PÉREZ-REGALADO, A.; GONZÁLEZHERNÁNDEZ, J.F. Riego localizado. Madrid: Mundi-Prensa, 1992. 405p. 
LOUSTAU, D.; DOMEC, J.C.; BOSC, A. Interpreting the variations in xylem sap flux density within the trunk of maritime pine (Pinus pinaster Ait.): application of a model for calculating water flows at tree and stand levels. Annales des Sciences Forestierès, v.55, p.29-40, 1998.

LU, P.; MÜLLER, W.J.; CHACRO, E.K. Spatial variations in xylem sap flux density in the trunk of orchard-grown, mature mango trees under changing soil water conditions. Tree Physiology, v.20, p683-692. 2000.

MACHADO, C.C. Influência da irrigação localizada na absorção de água do portaenxerto limão 'Cravo', em plantas adultas de lima ácida "Tahiti". Piracicaba, 2000. 92p. Dissertação (Mestrado) - Escola Superior de Agricultura "Luiz de Queiroz" Universidade de São Paulo.

MALAVOLTA, E; NETTO, A.V. Nutrição mineral, calagem, gessagem e adubação dos citros. Piracicaba: POTAFOS, 1989. 153p.

MANGUEIRA, D.S.; SILANS, A.M.B.P. de. Transpirômetro - Princípios teóricos e viabilidade técnica. Pesquisa Agrope cuária Brasileira, v.30, n.5, p.621-632, 1995.

MARIN, F. R. Evapotranspiração, transpiração e balanço de energia em pomar de lima ácida "Tahiti". Piracicaba, 2000. 74p. Dissertação (Mestrado) - Escola Superior de Agricultura "Luiz de Queiroz”- Universidade de São Paulo.

MARIN, R.R.; ANGELOCCI, L.R.; PEREIRA, A.R.; SENTELHAS, P.C.; VILLA NOVA, N.A. Balanço de energia e consumo hídrico em pomar de lima ácida 'Tahiti'. Revista Brasileira de Meteorologia, v.17, n.2, p.219-228. 2002.

MARSAL, J.; MATA, M.; GELLY, M.; GIRONA, J. Does peach tree hydraulic resistance play any role in maximum daily trunk shrinkage?. Acta Horticulturae, n. 537, p.337-344, 2000. 
McBURNEY, T.; COSTIGAN, P.A. The relationship between stem diameter and water potentials in stems of young cabbage plants. Journal of Experimental Botany, v.35, n.161, p.1787-1793, 1984.

MENDONÇA, P.V. Sobre o novo método de balanço hidrológico do solo de Thornthwaite-Mather. In: CONGRESSO LUSO-ESPANHOL PARA O PROGRESSO DAS CIÊNCIAS, 24., Madrid, 1958. Anais. Madrid: Instituto Superior de Agronomia, 1958. p.271-282.

MICHELAKIS, N. Daily stem radius variations as indicators to optimize olive tree irrigation scheduling. Acta Horticulturae, n.449, p.297-305, 1997. /Apresentado ao 2. International Symposium on Irrigation of Horticulture Crops, Greece, 1996/

MOLZ, F.J.; KLEPPER, B. On the mechanism of water stress induced stem deformation. Agronomy Journal, v.65, p.304-306, 1973.

MOREIRA, A.C. Água. Um recurso limitado. Panorama Rural, n.35, p.72, 2002.

MORIANA, A.; FERERES, E.; ORGAZ, F.; CASTRO, J.; HUMANES, M.D.; PASTOR, M. The relations between trunk diameter fluctuations and thee water status in olive trees (Olea europea L.). Acta Horticulturae, n.537, p.293-297, 2000. /Apresentado ao 3. International Symposium on Irrigation of Horticulture Crops, Lisboa, 2000/

NADEZHDINA, N. Specificity of sap flow index for mist irrigation control. Acta Horticulturae, n.537, p.479-485, 2000. /Apresentado ao 3. International Symposium on Irrigation of Horticulture Crops, Lisboa,1999/

NASR, Z. Mesure de débit du séve brute dans un arbre par une méthode thermique. Evaluation de la méthode et applications. Paris, 1989. 125 p. Thesis (Ph.D.) Université de Paris-Sud.

PARLANGE, J.Y.; TURNER, N.C.; WAGGONER, P.E. Water uptake, diameter change and nonlinear diffusion in tree stems. Plant Physiology, n.55, p.247-250, 1975. 
PIMENTEL, M. Especial Roraima. Sol, sonhos e coragem. Panorama Rural, n.35, p.52-65, 2002

SAKURATANI, T. A heat balance method for measuring water flux in the stem of intact plants. Journal of Agricultural Meteorology, v.37, p.9-17, 1981.

SATURNINO, H.M. Quanto custa a água, um bem maior e finito? Irrigação \& Tecnologia Moderna, n.48, p.42, 2000.

SATURNINO, H.M. Produção Integrada de frutas: Como tornar competitiva a fruticultura nacional. Irrigação \& Tecnologia Moderna, n.49, p.42, 2001.

SHACKEL, K.A.; JOHNSON, R.S.; MEDAWAR, C.K. Substantial errors in estimates of sap flow using the heat balance technique on woody stems under field conditions. Journal of the American Society for Horticultural Science, v.117, n.2, p.351-356, 1992.

SHACKEL, K.A.; AHMADI, H.; BIASI, W. Plant water status as an index of irrigation need in deciduous fruit trees. HortTechnology, v.7, n.1, p.23-29, 1997.

SHALHEVET, J., LEVY, Y. Citrus trees. In: TEWART, B.A., NIELSEN, D.R. Irrigation of Agricultural Crops. Madison: ASA, 1990. p.951-986.

SILVA, B.B. da; SLACK, D.C.; KILBY, M.W.; HLA, A.K. Measurements of water requirements of table grapes in Arizona (USA). Revista Brasileira de Agrometeorologia, v.8, n.2, p.175-183, 2000.

SIMÃO, S. Tratado de fruticultura. Piracicaba: FEALQ, 1998. 760 p.

SIMONNEAU, T.; HABIB, R.; GOUTOULY, J.P.; HUGUET, J.G. Diurnal changes in stem diameter depend upon variations in water content: Direct evidence in peach trees. Oxford University: Journal of Experimental Botany, v.44, n.260, p.615-621, 1993.

SMITH, M. Report on expert consultation on procedures from revision of FAO methodologies for crop water requirements. Rome: FAO, 1991. 45p. 
SMITH, D.M.; ALLEN, S.J. Measurement of sap flow in plants stems. Journal of Experimental Botany, v.47, n.305, p.1833-1844, 1996.

SMITH, M.; ALLEN, R.; MONTEITH, J.L.; PERRIER, A.; SANTOS PEREIRA, L.; SEGEREN, A. Report on the expert consultation on revision of FAO methodologies for crop water requirements. Rome: FAO, 1992. 44p

SO, H.B.; REICOSKY, D.C.; TAYLOR, H.M. Utility of stem diameter changes as predictors of plant canopy water potential. Agronomy Journal, v.71, p.707-713, 1979.

STEINBERG, S.L; VAN BAVEL, C.H.M.; McFARLAND, M. A gauge to measure mass flow rate of sap in stems and trunks of woody plants. Journal of the American Society for Horticultural Science, v.114, p.466-472, 1989.

STEINBERG, S.L; VAN BAVEL, C.H.M.; McFARLAND, M.J. Improved sap flow gauge for woody and herbaceous plants. Agronomy Journal, v.82, p.851-852, 1990.

TAVARES, R.A.F.R. Medição da transpiração e caracterização do estado hídrico em Prunus persica. Lisboa,1993. 74p. Trabalho (Graduação) - Instituto Superior de Agronomia, Universidade Técnica de Lisboa.

THORNTHWAITE, C.W.; MATHER, J.R. The water balance. Publications in Climatology, v.8, n.1, p.104, 1955.

THORPE, M.R. Net radiation and transpiration of apple trees in rows. Agricultural Meteorology, v.19, p.41-57, 1978.

TOURNEBIZE, R.; BOISTARD, S. Comparison of two sap flow methods for the estimation of tree transpiration. Annales des Sciences Forestierès, v.55, n.6, p.706$713,1998$.

TOZATTI, G. Notícias da Flórida. Citricultura atual, v.4, n.24, p.3, 2001 
TREJO-CHADIA, J.E. Avaliação do método de balanço de calor na estimativa da transpiração em tomateiros, plantas de milho e mudas de limoeiro. Piracicaba, 1997. 75p. Tese (Doutorado) - Escola Superior de Agricultura "Luiz de Queiroz", Universidade de São Paulo.

VALANCOGNE, C. Maximal transpiration of fruit trees measured by a heat balance sap flow method in relation to the climate and the orchard structure. Bordeaux: INRA, Laboratoire de Bioclimatologie, 1993. 11p.

VALANCOGNE, C.; GRANIER, A. Measures de flux de seive brute. Bordeaux: INRA, Station de Sylviculture et Production, 1994. 7p.

VALANCOGNE, C.; NASR, Z. Une methode de mesure du débit de séve brute dans des petits arbres par bilan de chaleur. Agronomie, n.9, p.609-617, 1989.

VALANCOGNE, C.; NASR, Z. A heat balance method for measuring sap flow in small trees. In: BORGHETTI, M.; GRACE, J.; RASCHI, A. Water transport in plants under climatic stress. Cambridge: Cambridge University Press, 1993. p.166-173.

VAN BAVEL, M.G. System solution for Real-Time sap flow monitoring. International Water \& Irrigation Review, v.13, n.1, p.25-29, 1993.

VIEIRA, D. B. As técnicas de irrigação. São Paulo: Globo, 1995. 263p. (Coleção do Agricultor. Publicação Globo Rural).

WEIBEL, F.P.; VOS, J.A.de. Transpiration measurements in apple trees: an improved stem balance heat method. Plant and Soil, v.166, p.203-217, 1994.

ZANINI, J.R.; PAVANI, L.C.; SILVA, J.A.A. Irrigação em citros. Jaboticabal: Funep, 1998. 34p. 